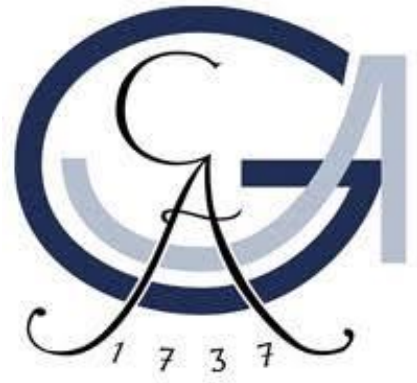

Georg-August-Universität Göttingen

Fakultät für Forstwissenschaften und Waldökologie

Burckhardt-Institut

Abteilung Waldbau und Waldökologie der gemäßigten Zonen

\title{
The effect of neighborhood identity on seasonal tree growth responses and ecophysiological characteristics of European beech (Fagus sylvatica $\mathbf{L}$.)
}

Zum Einfluss unterschiedlicher Nachbarschaftsverhältnisse von Einzelbäumen auf das saisonale Baumwachstum und ökophysiologische Merkmale der Rotbuche

(Fagus sylvatica L.)

Dissertation

zur Erlangung des Doktorgrades (Dr. forest.)

der Fakultät für Forstwissenschaften und Waldökologie

der Georg-August-Universität Göttingen

vorgelegt von

Jérôme Metz

geboren in Lebach

Göttingen, Juni 2019 


\section{Examination board:}

\section{Referee: Prof. Dr. Christian Ammer}

University of Göttingen

Faculty of Forest Sciences and Forest Ecology

Burckhardt-Institute

Department of Silviculture and Forest Ecology of the Temperate Zones

Büsgenweg 1

37077 Göttingen, Germany

\section{Referee: Prof. Dr. Ernst-Detlef Schulze}

Max Planck Institute for Biogeochemistry

Hans-Knoell-Straße 10

07745 Jena, Germany

\section{Referee: Prof. Dr. Alexander Knohl}

University of Göttingen

Faculty of Forest Sciences and Forest Ecology

Büsgen-Institute

Department of Bioclimatology

Büsgenweg 2

37077 Göttingen, Germany

Date of oral examination: 27 August 2019 


\section{Fivis meine Familiel}

"Nichts ist für mich mehr Abbild der Welt und des Lebens als der Baum.

Vor ihm würde ich täglich nachdenken, vor ihm und über ihn..."

Christian Morgenstern

(1871-1914) 


\section{Table of contents}

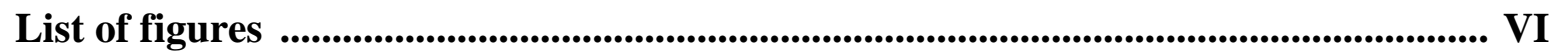

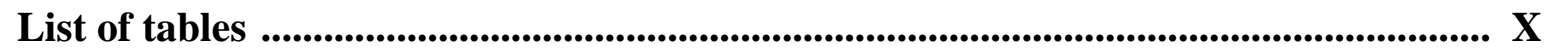

List of supplementary material / supporting information............................................. XI

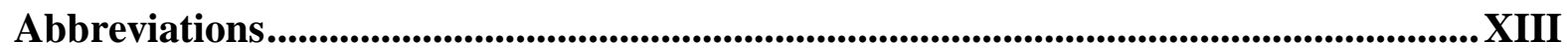

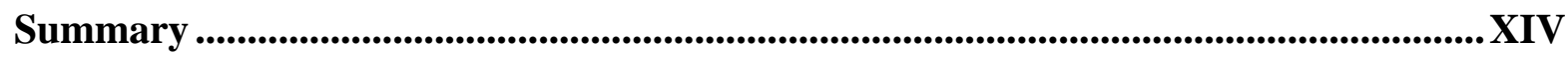

Zusammenfassung ............................................................................................................................ XVIII

Chapter 1: General Introduction ...................................................................... 1

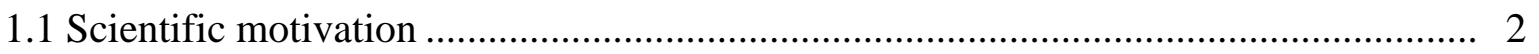

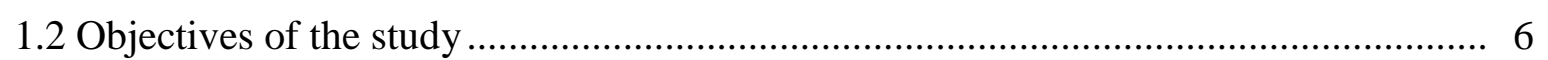

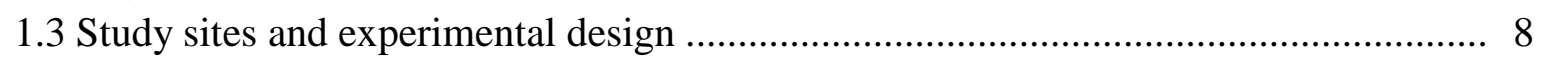

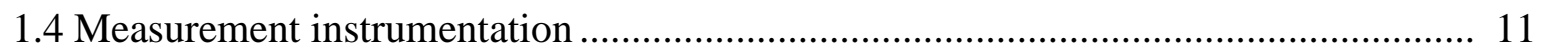

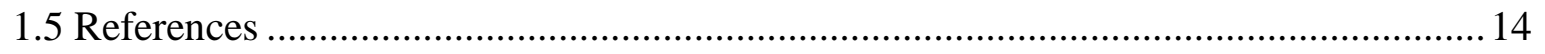

Chapter 2: Crown modeling by terrestrial laser scanning as an approach to assess the effect of aboveground intra- and interspecific competition on tree growth .......... 25

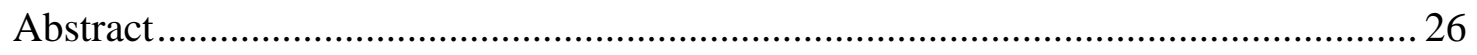

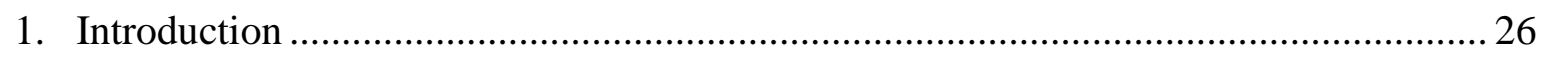

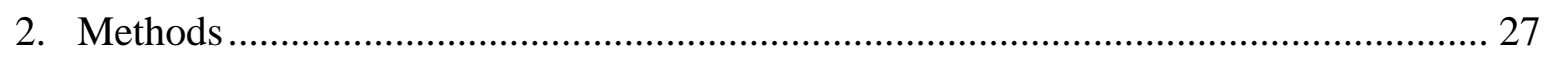

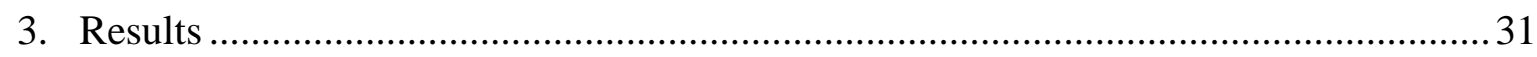

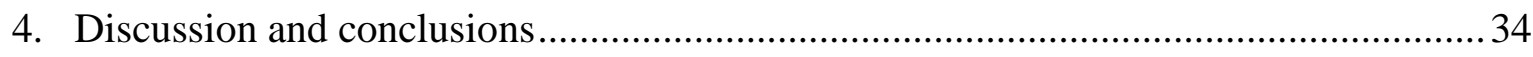

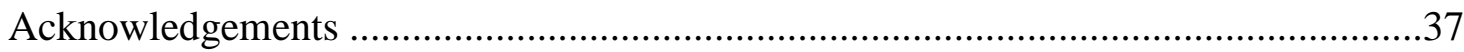

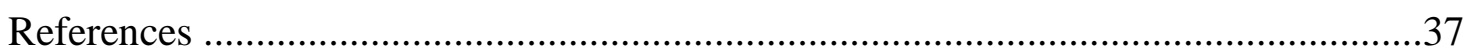

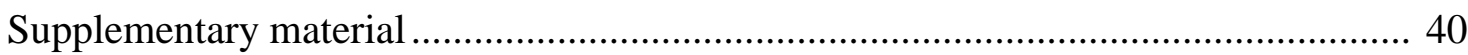

Chapter 3: Site-adapted admixed tree species reduce drought susceptibility of mature European beech .............................................................................................................43

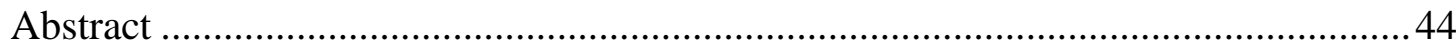

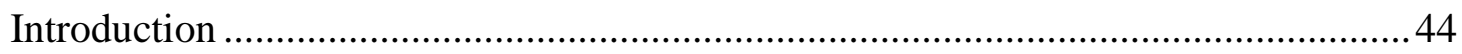

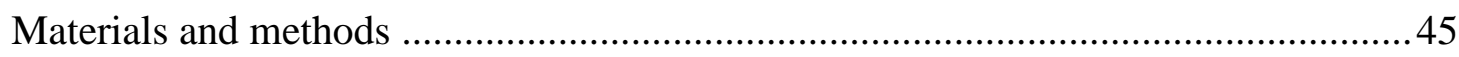

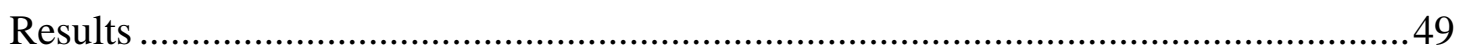

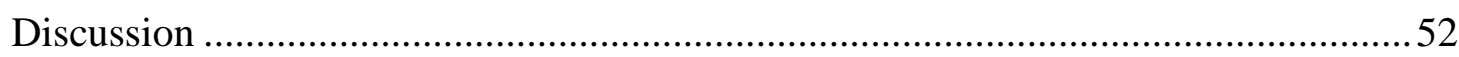

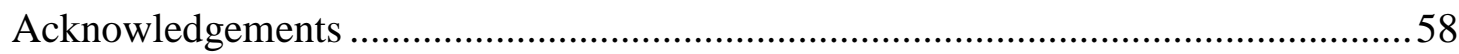

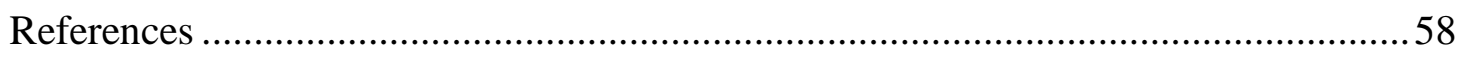

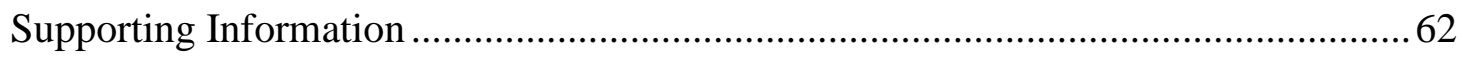


Chapter 4: Less is more: Effects of competition reduction and facilitation on intraannual (basal area) growth of mature European beech ....................................................66

Abstract

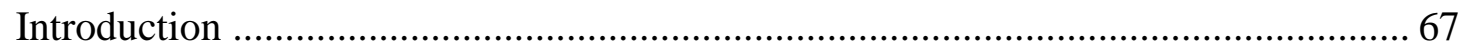

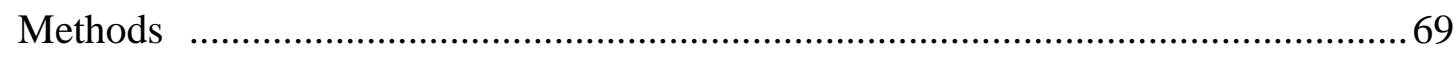

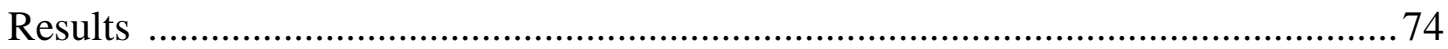

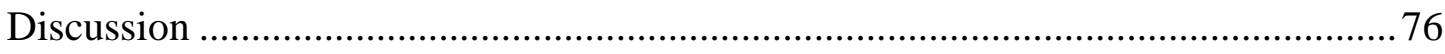

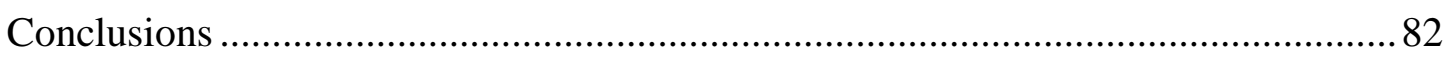

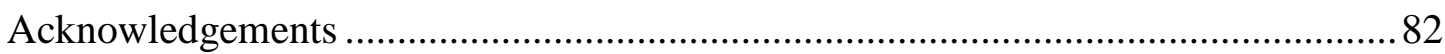

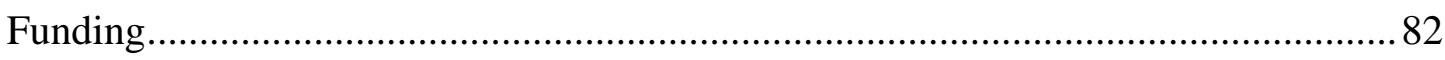

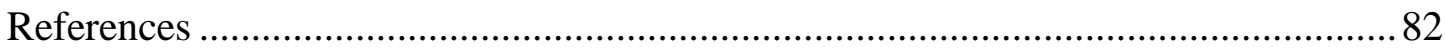

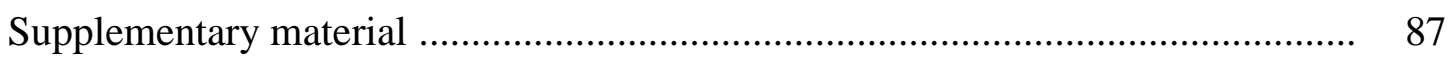

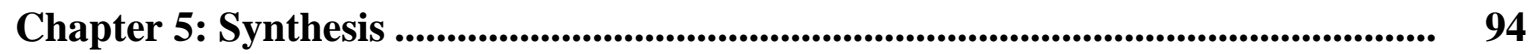

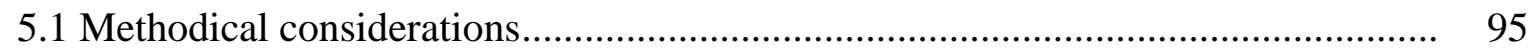

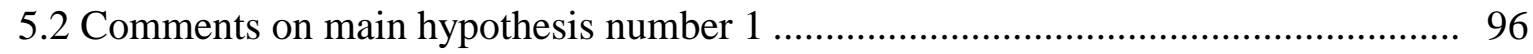

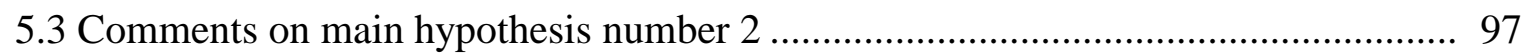

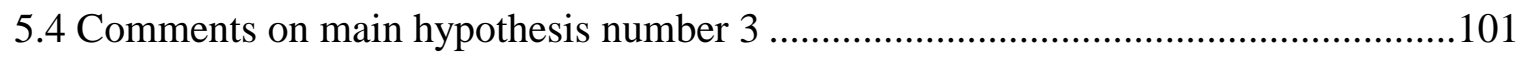

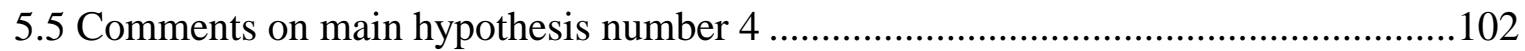

5.6 Cause-and-effect relationships for obserevd growth responses and related plant

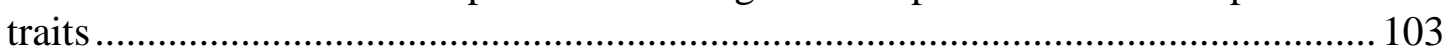

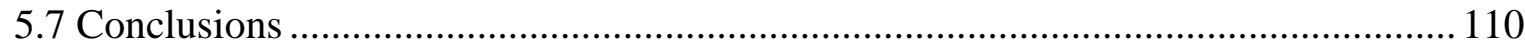

5.8 Brief general remarks on adaptive forest management and mixed-species forests.... 111

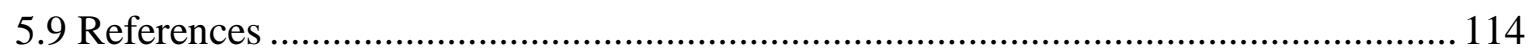

Publication list of author .......................................................................................... XXIII

Acknowledgements.......................................................................................................................... XXIV

Curriculum vitae ..............................................................................................................................XXVI

Declaration of originality and certificate of ownership ..........................................XXVII 


\section{List of figures}

\section{Chapter 1}

Fig. 1.1: Basic information on geographic locations and environmental conditions of the three Biodiversity Exploratories (cf. Fischer et al. 2010).

Fig. 1.2: Electronic self-acting DC2 circumference dendrometer with Scatter 100 sensor unit (left respectively top right) and Scatter 100 base station (bottom right).

Fig. 1.3: Core sample extraction from a target beech tree (top left) and ready prepared increment cores for dendrochronological analysis (bottom and top right).

Fig. 1.4: Terrestrial laser scanner Zoller and Froehlich Imager 5006 (left), exemplary point cloud of a tree group generated from scanner data after 3D-measuring (middle) and structural tree parameters that were derived from voxel models (right).

\section{Chapter 2}

Fig. 1: Sample 2D-representations of 3D-point clouds of the investigated competitive situations. From left to right: beech vs. beech; beech vs. valuable hardwood; beech vs. spruce; beech vs. pine.

Fig. 2: Calculation of the competition index KKL based on crown shape models (Pretzsch et al., 2002).

Fig. 3: An example of application of the search cone to detect competitors and the formula to measure the competitive strength enforced on a target tree based on TLS-data.

Fig. 4: Relationship between crown structural parameters calculated with the same algorithm but based on two different point clouds created by two different operators.

Fig. 5: Boxplots of both competition indices separately for the different competitor tree species.

Fig. 6: Relationship between the competition indices KKL and CCSA respectively CCSA $\mathrm{Cone}_{\mathrm{C}}$ for the 24 target tree beeches under intra- and interspecific competition.

Fig. 7: Mean basal area increment of the target tree beeches in relative (\% of initial basal area, left) or absolute $\left(\mathrm{cm}^{2}\right.$, right) terms under intra- and interspecific competition.

Fig. 8: Relationship between target tree basal area increment in the 2012 vegetation period and the competitive stress enforced to the trees according the model based KKL-index and the TLS-based index respectively. 
Fig. 9: TLS-derived crown shapes of two beech trees with almost the same height and dbh in comparison to the congruent geometric model.

\section{Chapter 3}

Fig. 1: Raw and standardized site chronologies (top) as well as average ring-widths of mean time series (bottom) calculated from target tree beeches being exposed to either intraor interspecific competition. Different letters above the box-whiskerplots indicate significant differences between mean ring widths of raw site chronologies within the same Exploratory (nonparametric Tukey multiple comparison test: $\mathrm{P}<0.05$ ).

Fig. 2: (a) Drought resistance of target beeches in groups of intra- or interspecific competition during the dry year 1976. (b) Radial growth recovery of target beeches in groups of intra- or interspecific competition during the postdrought year 1977 (c) comparison between post- and predrought growth levels ( $\hat{=}$ resilience) of target beeches in groups of intra- or interspecific competition. Asterisks label a significant growth decline and rhombi a full recovery in the postdrought year as mean index ratios significantly differ from 1 (one-sample $t$ test: $\mathrm{P} \leq 0.05$ ).

Fig. 3: (a) Drought resistance of target beeches in groups of intra- or interspecific competition during the dry year 2003. (b) Radial growth recovery of target beeches in groups of intra- or interspecific competition during the postdrought year 2004. (c) Comparison between post- and predrought growth levels ( $\hat{=}$ resilience) of target beeches in groups of intra- or interspecific competition. Asterisks label a significant growth decline and rhombi a full recovery in the postdrought year as mean index ratios significantly differ from 1 (one-sample $t$ test: $\mathrm{P} \leq 0.05$ ). Superscript letters above the box-whisker-plots indicate significant differences between target trees of the same Exploratory that are exposed to either intra- or interspecific competition (npar.t.test: $\mathrm{P} \leq 0.05$ ).

Fig. 4: Ring-widths as well as corrected (yearly averages $\mp 1 \mathrm{SE}$ ) and normalized $\delta^{13} \mathrm{C}$ signatures of target trees in groups of intra- or interspecific competition during the 4year periods 1975-1978. Asterisks label significant differences between annual means of beeches from pure and mixed stands of the same Exploratory (npar.t.test: $\mathrm{P} \leq 0.05$ ).

Fig. 5: Ring-widths as well as corrected (yearly averages $\mp 1 \mathrm{SE}$ ) and normalized $\delta^{13} \mathrm{C}$ signatures of target trees in groups of intra- or interspecific competition during the 4year periods 2002-2005. Asterisks label significant differences between annual means of beeches from pure and mixed stands of the same Exploratory (npar.t.test: $\mathrm{P} \leq 0.05$ ). 
Fig. 6: Relationship between wood stable isotope ratios ( $\overline{\mathrm{x}}$ for the period $2002-2005)$ as a measure for water stress and competitive pressure $\left(\mathrm{CCSA}_{\mathrm{Cone}}\right)$ enforced to target tree beeches in intra- or interspecific neighborhoods.

Fig. 7: (a) relative $\delta^{13} \mathrm{C}$ increase due to the 1976 precipitation deficit calculated as the quotient of tree-ring $\delta^{13} \mathrm{C}$-values from the predrought and drought year. (b) Relative $\delta^{13} \mathrm{C}$ decrease in 1977 calculated as the quotient of tree-ring $\delta^{13} \mathrm{C}$-values from the drought and postdrought year. Asterisks and rhombi label a significant $\delta^{13} \mathrm{C}$ increase, respectively, decrease as mean index ratios differ significantly from 1 (one-sample $t$ test: $\mathrm{P} \leq 0.05)$. Superscript letters above box-whisker-plots indicate significant differences between target trees of the same Exploratory that are exposed to either intra-or interspecific competition (npar.t.test: $\mathrm{P} \leq 0.05$ ).

Fig. 8: (a) relative $\delta^{13} \mathrm{C}$ increase due to the 2003 precipitation deficit calculated as the quotient of tree-ring $\delta^{13} \mathrm{C}$-values from the predrought and drought year (b) relative $\delta^{13} \mathrm{C}$ decrease in 2004 calculated as the quotient of tree-ring $\delta^{13} \mathrm{C}$-values from the drought and postdrought year. Asterisks and rhombi label a significant $\delta^{13} \mathrm{C}$ increase respectively decrease as mean index ratios differ significantly from 1 (one-sample $t$ test: $\mathrm{P} \leq 0.05)$.

\section{Chapter 4}

Fig. 1: Overview of geographic locations and site conditions in the three study areas.

Fig. 2: Subject tree with four competitors $(\mathrm{c} 1-\mathrm{c} 4)$ representing pure European beech stands (left) and groups of interspecific neighborhood (right).

Fig. 3: Fully preprocessed dendrometer data sets for statistical evaluation (vegetation periods 2012 and 2013) with daily mean values from subject tree beeches that are exposed to either intra- or interspecific competition in the Exploratories SCH (a), HAI (b) and $\operatorname{ALB}(\mathrm{c})$.

Fig. 4: Relative basal area increment of subject trees being exposed to either intra- or interspecific competition ( $a, b)$ as well as impact of competition intensity (CCSA) on relative BAI of the subject trees (c,d). Different letters above the box-whisker-plots indicate significant differences between mean BAI (\%) of beeches from the same Exploratory that are growing in groups of intra- or interspecific competition (npar.t.test: $\mathrm{p} \leq 0.05$ ). 
Fig. 5: Temporal variability of subject tree growth under intra- and interspecific competition derived from cumulative (parameters $T$ and $m$ ), respectively, inverse (e-j) Weibull functions. Lowercase letters above or below the box-whisker-plots indicate significant differences between subject trees of the same Exploratory that are exposed to either intra- or interspecific competition (npar.t.test: $\mathrm{p} \leq 0.05$ ).

Fig. 6: Comparisons of increment culmination (days elapsed since April 1st) between subject trees of the same study region being exposed to either intra- or interspecific competition. Different letters above the box-whisker-plots indicate significant differences between subpopulations from pure and mixed stands of the same Exploratory (npar.t.test: $\mathrm{p} \leq 0.05)$.

Fig. 7: Calculated average daily radial growth rates (monthly view) of subject beeches in groups of intra- or interspecific competition. Asterisks label significant differences between subject trees of the same Exploratory that are exposed to either intra- or interspecific competition (npar.t.test: $\mathrm{p} \leq 0.05$ ).

\section{Chapter 5}

Fig. 5.1: Conceptual framework to explain the relationship between species diversity-related below- or aboveground relaxation and enhanced stand productivity. Bold arrows describe positive diversity-productivity interactions whereas dashed arrows refer to negative feedbacks associated with climate change (adopted from Ammer 2019 and adjusted).

Fig. 5.2: TLS-derived crown surface areas of target tree beeches $\left(=\mathrm{CSA}_{\mathrm{TT}}\right)$ in spring 2012 in groups of either intra- or interspecific competition separately for each Exploratory (cf. Fig. S3 in Metz et al. 2016). 


\section{List of tables}

\section{Chapter 1}

Table 1.1: Schematic presentation of and general information on the sampling design.

\section{Chapter 2}

Table 1: General information on the study sites located in Northeast-, Central- and Southwest Germany (information on soil properties from Solly et al., 2013).

Table 2: Main characteristics of target trees and their neighbors in the three Biodiversity Exploratories.

Table 3: Results of competitor selection with the search-cone in case of modeled and real crowns.

Table 4: Evaluation of linear mixed effects model fits using the information-theoretic AICcapproach.

\section{Chapter 3}

Table 1: Main characteristics of target trees and their neighbors derived from TLS data.

Table 2: Statistical parameters of raw (RAW) and standard (STD) chronologies from the three different study areas for the period 1970-2011. Asterisks label a significant difference between mean ring widths of raw site chronologies from pure and mixed stands within the same Exploratory (package 'nparcomp': $\mathrm{P}<0.05$ ).

\section{Chapter 4}

Table 1: General weather conditions during the two vegetation periods, related to the duration and magnitude of tree growth in the different study regions.

Table 2: TLS-based key structural characteristics of subject beech trees and their competing neighbors (cf. Metz et al. 2016).

\section{Chapter 5}

Table 5.1: Summary on pair-wise tests (within Exploratories) and all-pairs comparisons (across Exploratories) between target tree subpopulations that were exposed to either intra- or interspecific competition.

Table 5.2: Summary on pair-wise tests between target tree subpopulations of the same Exploratory that were exposed to either intra- or interspecific competition. 


\section{List of supplementary material / supporting information}

\section{Supplementary material chapter 2:}

Appendix A: Absolute measurement errors of tree parameters selected for the comparator check.

Appendix B: Measures of dispersion and correlation coefficients for both competition indices.

Appendix C: Target tree basal area growth $\left[\mathrm{cm}^{2}\right]$ and its relationship to the competition indices tested in this study.

Appendix D.1: Adjusted p-values for the multiple comparison of mean with Wilcoxon's rank sum test.

Appendix D.2: Adjusted p-values of the nonparametric multiple comparison (type of contrast: Tukey).

Appendix E: Evaluation of all candidate lme-model fits using the information-theoretic AICcapproach.

Appendix F: Correlations of tested competitor crown parameters with target tree basal area growth.

\section{Supporting information chapter 3:}

Figure S1: General information on the study sites located in Northeast-, Central- and Southwest Germany (information on soil properties from Solly et al., 2013).

Figure S2: Monthly mean precipitation sums (bar plots) and monthly mean air temperatures (line graphs) during the growing season for the period 1970-2011. Dotted horizontal lines mark the 41-year average temperature for the interval April to September.

Figure S3: TLS-derived crown surface areas $\left(\mathrm{m}^{2}\right)$ of target tree beeches in spring 2012 that are exposed to either intra- or interspecific competition separately for each study area.

Table S1: Relationships between target tree ring-widths and $\delta^{13} \mathrm{C}_{\mathrm{corr}}$-values estimated with Pearson's product moment correlation coefficient (r) for the 4-year periods 19751978 as well as 2002-2005. 


\section{Supplementary material chapter 4:}

Fig. S1: Monthly mean precipitation sums (bar plots) and monthly mean air temperatures (line graphs) during both years under investigation (2012-2013).

Fig. S2: Plotted raw time series (April $1^{\text {st }} 2012$ to September $30^{\text {th }} 2013$ ) of half-hourly dendrometer measurement values from subject tree beeches that are exposed to either intra- or interspecific competition in the Exploratories SCH (A), HAI (F) and ALB (K). Weibull functions fitted to rescaled dendrometer profiles (B, D, G, I, L, N) and first-order derivatives of mean seasonal radial growth curves $(\mathrm{C}, \mathrm{E}, \mathrm{H}, \mathrm{J}, \mathrm{M}, \mathrm{O})$ used for comparisons of increment culmination between subpopulations from pure and mixed stands of the same study region.

Fig. S3: Absolute basal area increment of subject trees being exposed to either intra- or interspecific competition (top) as well as impact of competition intensity (CCSA) on absolute BAI of the subject trees (bottom). Different letters above the box-whiskerplots indicate significant differences between mean BAI $\left(\mathrm{cm}^{2}\right)$ of beeches from pure and mixed stands of the same Exploratory (npar.t.test: $\mathrm{p} \leq 0.05$ ).

Table S1: Calculated average daily radial growth rates (in $\mu \mathrm{m}$ ) on a monthly level as a proxy for diurnal productivity.

Table S2: Monthly mean air temperatures $\left[{ }^{\circ} \mathrm{C}\right]$ and monthly precipitation sums $[\mathrm{mm}]$ during both years under investigation (2012-2013).

Table S3: (inverse) Weibull parameter function values.

Table S4: Information on onset, cessation and total duration of subject tree wood formation (specified in days since April $1^{\text {st }}$ ) under intra- or interspecific competition. 


\section{Abbreviations}

AIC

ALB

BAI

$\mathrm{CCSA}_{(\text {Cone })}$

$\mathrm{cm}$

CSA

CV

DBH

DFG

DOY $_{\text {max growth }}$

EP

GPP

HAI

KKL

MAAT

MAP

$\mathrm{mm}$

$\mathrm{m}^{2}$

$\mathrm{m}^{3}$

$\mathrm{R}$

$\mathrm{R}_{\mathrm{c}}$

$\mathrm{R}_{\mathrm{s}}$

$\mathrm{R}_{\mathrm{t}}$

RWI

r

SD

SE

$\mathrm{SCH}$

TLS

TTH
Akaike information criterion

Exploratory 'Swabian Alb'

Basal area increment

Competitors' Crown Surface Area (competition index)

centimeter

crown surface area

crown volume

diameter at breast height

Deutsche Forschungsgemeinschaft

day of year maximum growth

experimental plot

gross primary productivity

Exploratory 'Hainich-Dün'

Kronenkonkurrenz um Licht (competition index)

mean annual air temperature

mean annual precipitation

millimeter

square meter

cubic meter

coefficient of determination

recovery

resilience

resistance

ring width index

coefficient of correlation

standard deviation

standard error

Exploratory 'Schorfheide-Chorin'

terrestrial laser scanning

total tree height 


\section{Summary}

Climate change related rise in mean surface (air) temperature, altered intra-annual thermal and precipitation regimes as well as an expected increase of extreme weather events which are also prognosticated for large parts of Europe can impair the vitality or rather the productivity of long-living forest ecosystems. This also applies to beech forest communities (Fagion sylvaticae), although due its competitive superiority and wide niche breadth, common beech (Fagus sylvatica L.) is one of the most important (economic) tree species of Central Europe that plays a key role in numerous programmes for the conversion of large scale coniferous monocultures. In addition to slow (epi-) genetic adaptation responses, at least in commercial forests, different silvicultural measures are suitable to mitigate the impacts and risks of changing climate or weather conditions in order to secure the maintenance of all forest ecosystem services.

It is a main objective of active silvicultural interventions to improve resource availability, uptake as well as use efficiency at the individual tree and, respectively, stand level. This aim can either be achieved by stand density reductions during regular spacings with adequate thinning grades or by admixing site-adapted co-occuring tree species. Two fundamental processes are considered key factors for positive interactions between mixed species in diverse forests: competition reduction or facilitation. A more profound understanding of these complex interactions and competition processes in mixed stands is indispensable for the development of appropriate silvicultural management options or adaptation strategies that are based upon scientific research.

In view of these particular circumstances, the main objectives of this study were the following:

a) to measure the impact of competition intensity and neighborhood identity, which are both closely linked to silvicultural management interventions, on stem growth patterns of beech target trees at various time scales (day to year)

b) to explain the revealed growth response of selected beech target trees as a function of their competitive neighborhood

c) to explain the revealed growth pattern by analyzing growth related ecophysiological and morphological plant traits such as stable isotope ratios or crown architecture

The collection of data necessary to address these study aims was conducted on permanent field plots which were established in three long-term research sites. These three 
'Exploratories' were set up in the German Federal States of Brandenburg (Biosphere Reserve Schorfheide-Chorin), Thuringia (Hainich National Park including its surrounding area) as well as Baden-Wuerttemberg (Biosphere Reserve Swabian Alb) and are the key elements of a DFG-funded (Deutsche Forschungsgemeinschaft) research platform for functional biodiversity research, the 'Biodiversity Exploratories'. Within each Exploratory, eight standardized tree groups were selected. Half of them were located in pure beech stands and the other half in regionally typical mixed stands. Each of the 24 tree groups consisted of exactly five uniformly arranged single trees. One beech in the centre of the tree group (= target tree) was surrounded by exactly four similarly dimensioned neighboring trees (= competitors) that were arranged symmetrically and in a comparable distance around the central tree. In order to be able to compare the effect of intra- or interspecific competition on growth responses and related plant traits of European beech, the target trees were either exclusively encircled by other beeches or by the regionally typical, site-adapted admixed tree species Scots pine (Schorfheide-Chorin), Norway spruce (Swabian Alb) respectively valuable hardwoods (Hainich-Dün).

As most of the approaches that have so far been applied to investigate the relationship between (crown) competition and individual tree growth insufficiently considered the variability of processes and especially crown shapes in the canopy of (mixed) forests, in a first study a competition index $\left(\mathrm{CCSA}_{(\mathrm{Cone})}=\right.$ Competitors' Crown Surface Area) was derived from terrestrial laser scans (TLS). This index is based on real crown shapes of the competitor trees and considers their species identity by including specific coefficients of transmission (chapter 2). In case of equal neighborhood density, compared to the intra-specific competition pressure target tree beeches in pure stands were exposed to, aboveground inter-specific competition emanating from valuable hardwoods, spruce or pine on beech was evaluated as being (significantly) lower. Across-site comparisons showed that relative basal area growth of the target trees at the end of the 2012 vegetation period behaved strictly opposite to competition intensity. Beeches that were exclusively surrounded by pine trees achieved by far the highest relative basal area growth rates, followed by those target trees competing with Norway spruce or valuable hardwoods for light, water and nutrients. Target tree beeches in pure stands exhibited the lowest relative basal area increment rates. Correlation analysis and the application of linear mixed effects regression models to describe the (functional) relationship between absolute one-year basal area growth and competition indicated, that the TLS-based index ' $\mathrm{CCSA}_{(\mathrm{Cone})}$ ' explained growth response of beech target trees better than a competition 
index based on geometrical crown shapes. Thus, ' $\mathrm{CCSA}_{(\mathrm{Cone})}$ ' can contribute to improve the understanding of competition processes especially in mixed stands.

For a further study, dendrochronological investigations and measurements of the wood $\delta^{13} \mathrm{C}$ signature of all 24 target tree beeches were combined. Pairwise comparisons within the three Exploratories revealed that, referring to the evaluation period 1970-2011, average radial growth rates of beeches growing in pure stands were (significantly) lower than those of target trees exclusively surrounded by regionally-typical admixed tree species (Scots pine, valuable hardwoods or Norway spruce). This basic growth pattern was also often observed during the extremely dry years 1976 and 2003, although water stress-induced relative growth depression was generally weaker in pure beech stands. However, beeches exposed to intra-specific competition recovered more slowly from drought-induced growth depression than the respective subpopulation of the same investigation area that was surrounded by regionallytypical admixed tree species. Ring-width measurements and especially the wood stable isotope analysis suggested an improved water supply of those beeches surrounded by (less competitive) admixed tree species during periods with distinct rainfall deficits which, due to the ongoing climate change, are expected to occur more frequent in the future (chapter 3 ).

In the framework of the third study (chapter 4), over a period of two years, half-hourly stem girth microvariations of all 24 target tree beeches were continuously recorded using electronic dendrometers to evaluate the influence of competition intensity and neighborhood identity on intra-annual stem growth pattern of European beech on various time scales (day to year). At the end of the vegetation periods 2012 and 2013, relative basal area growth of the target tree beeches exclusively exposed to inter-specific competition by regionally-typical admixed tree species were consistently (but sometimes insignificantly) higher than in the pure stands of the same Exploratory. Simple linear regression analyses approximated a significant functional relationship between relative basal area growth (= response variable) and the TLS-derived competition index CCSA (= predictor variable) for both years. Fitting Weibull growth curves to rescaled dendrometer profiles provided parameter estimates appropriate for intra-regional comparisons of seasonal beech growth dynamics in pure or mixed stands. Only in mixture with Scots pine, interspecific competition triggered a (significant) prolongation of target tree wood formation compared to beech growth dynamics in pure stands of the same region. Competitive neighborhoods consisting of Norway spruce or valuable hardwoods, however, did not induce consistent trends towards extended growth durations under interspecific interference. It seems as if in competitive neighborhoods composed of Norway spruce or 
valuable hardwoods, potential beneficial mixing effects on intra-annual growth dynamics are counterbalanced by small-scale differences in site or weather conditions.

Within the same Exploratory, the monthly progress of daily average stem growth rates (in $\mu \mathrm{m}$ ) of beeches growing under intra- or interspecific competition almost paralleled. However, only target tree beeches from the Swabian Alb pure stands regularly attained the daily growth rates of their conspecifics growing in mixture with Norway spruce. Within the two other Exploratories, superior diurnal growth rates of beeches in mixed stands attributable to (lower) interspecific competition by Scots pine or valuable hardwoods occurred. This allows the conclusion that intra-annual beech growth dynamics are primarily controlled by environmental impacts and site conditions. Species-specific mixing effects can positively influence diurnal growth rates of target tree beeches at a given site, but they are not strong enough to overcome fundamental growth-environment interactions throughout the year.

In summary, it can be concluded that the vulnerability of European beech to environmental constraints associated with global warming is co-determined by competition intensity and species identity of the neighboring trees. The results of this study imply, that the more complementary functional traits of admixed tree species and beech are, the lower is the competitive stress the latter is exposed to. Distinct trait variation, in turn, has a positive impact on resource supply, especially water availability of European beech and thus on its long-term growth performance and short-term drought response. However, the net effect of competition reduction or facilitation in interspecific neighbourhoods on growth and resource use of beech depends on a complex interplay of several factors. In addition to temporal, spatial, morphological or physiological niche complementarity between beech and the admixed tree species, site as well as climatic conditions or rather the growth limiting resource itself determine the magnitude of relaxation.

Nonetheless, the systematic, preferably small-scale admixture of site-adapted co-occuring tree species into pure beech stands can be considered as an appropriate silvicultural measure to mitigate negative effects of climate change and more frequent drought events on growth and vitality of European beech.

This, of course, must not only be considered under the aspects of forest utilization and risk management, but it can also be of vital importance for the maintenance of all other equally important forest ecosystem services. 


\section{Zusammenfassung}

Die in Folge des Klimawandels auch für weite Teile Europas prognostizierte Durchschnittstemperaturerhöhung und Veränderung des Niederschlagsregimes sowie eine erwartete Zunahme von Witterungsextremen können die Vitalität bzw. Produktivität langlebiger Waldökosysteme beeinträchtigen. Obwohl die Rotbuche (Fagus sylvatica L.) auf Grund ihrer Konkurrenzüberlegenheit sowie breiten standörtlichen Amplitude eine der wichtigsten (Wirtschafts-) Baumarten Mitteleuropas ist und in zahlreichen Programmen zum Umbau großflächiger Nadelholzreinbestände eine zentrale Rolle spielt, gilt dies grundsätzlich auch für Buchenwaldgesellschaften (Fagion sylvaticae). Neben automatisch aber sehr verzögert verlaufenden (epi-) genetischen Anpassungsprozessen können zumindest in Wirtschaftswäldern zur Sicherstellung der Aufrechterhaltung aller Ökosystemdienstleistungen auch waldbauliche Maßnahmen ergriffen werden, die geeignet sind, Auswirkungen sowie Risisken sich verändernder Klima- und Witterungsverhältnisse abzumildern.

Eine primäre Intention des aktiven Wald(um)baus ist es, die Verfügbarkeit, Aufnahme sowie Nutzungseffizienz wichtiger Ressourcen auf Einzelbaum- respektive Bestandesebene zu verbessern. Dies kann entweder im Zuge von Stammzahlreduktionen während regelmäßiger Durchforstungen mit angemessenen Eingriffsstärken oder durch Einbringung standortgerechter Mischbaumarten erreicht werden. Positive Wechselwirkungen zwischen Mischbaumarten können wiederum auf zwei grundsätzlichen Prozessen basieren: Konkurrenzreduktion oder gegenseitige Förderung. Ein tiefgreifenderes Verständnis dieser komplexen Interaktionen und Konkurrenzprozesse in Mischbeständen ist unabdingbare Voraussetzung, um auf Grundlage fundierter forstwissenschaftlicher Forschung erkenntnisbasierte Bewirtschaftungsmaßnahmen oder Anpassungsstrategien abzuleiten.

Folglich bestanden die Ziele dieser Arbeit darin:

a) Das Dickenwachstum ausgewählter Buchen auf unterschiedlichen Zeitskalen (Tag bis Jahr) als Funktion ihrer Nachbarschaft zu erfassen.

b) Aufzudecken, welchen Anteil an den Wachstumsmustern die Artzugehörigkeit der Nachbarn hat.

c) Die gefundenen Zuwachsreaktionen durch die Analyse ökophysiologischer Prozesse kausal zu erklären.

Jene für die Bearbeitung der daraus resultierenden Fragestellungen erforderlichen Datenaufnahmen erfolgten auf Versuchsflächen dreier Langzeituntersuchungsgebiete, den 
sog. Biodiversitäts-Exploratorien. Diese sind zentrale Elemente einer von der Deutschen Forschungsgemeinschaft (DFG) finanzierten Forschungsplattform zur funktionellen Biodiversitätsforschung und wurden in Brandenburg (Biosphärenreservat SchorfheideChorin), Thüringen (Nationalpark Hainich einschließlich seiner Umgebung) sowie BadenWürttemberg (Biosphärengebiet Schwäbische Alb) eingerichtet. Innerhalb jedes Exploratoriums wurden acht Baumgruppen ausgewählt, die sich wiederum zur Hälfte in Buchenreinbeständen sowie in gebietstypischen Mischbeständen befanden. Alle 24 Baumgruppen bestanden aus genau fünf Einzelbäumen mit einheitlicher Grundanordnung. Um eine im Zentrum der Baumgruppe stehende Buche (= target tree) waren möglichst symmetrisch und mit vergleichbarem Abstand genau vier Nachbarbäume (= competitor trees) ähnlicher Dimension angeordnet. Um die Auswirkungen intra- und interspezifischer Konkurrenz miteinander vergleichen zu können, handelte es sich bei den Konkurrenten entweder ausschließlich um Buchen oder um die gebietstypischen Mischbaumarten Kiefer (Schorfheide), Fichte (Schwäbische Alb) bzw. Edellaubhölzer (Hainich).

Da die meisten der bisher angewendeten Modelle zur Erforschung des Zusammenhangs zwischen (Kronen-) Konkurrenz und Einzelbaumzuwachs die Prozess- sowie Formenvielfalt im Kronenraum von (Misch-) Beständen nur unzureichend abbilden, wurde in einer ersten Studie zunächst auf Grundlage terrestrischer Laserscans (TLS) ein eigener Konkurrenzindex

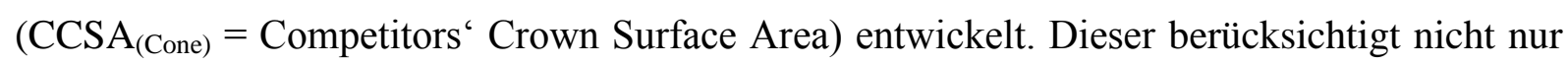
die individuelle Kronenstruktur jedes Nachbarbaumes, sondern in Form eines artspezifischen Transmissionskoeffizienten auch die Baumart der jeweiligen Konkurrenten (Kapitel 2). Verglichen mit dem intraspezifischen Konkurrenzdruck dem die in Reinbeständen untersuchten Buchen ausgesetzt waren, wurde die von Edellaubhölzern, Fichten oder Kiefern ausgehende interspezifische Konkurrenz bei gleicher Dichte als (z.T. signifikant) niedriger bewertet. Bei gebietsübergreifender Betrachtung verhielt sich der prozentuale Grundflächenzuwachs des Jahres 2012 genau umgekehrt zur ermittelten Konkurrenzintensität. Ausschließlich von Kiefern umgebene Buchen leisteten die mit Abstand höchsten relativen Grundflächenzuwächse, gefolgt von denjenigen Bäumen, die mit Fichten oder Edellaubhölzern um Licht, Wasser und Nährstoffe konkurrierten. Am geringsten fiel der prozentuale Grundflächenzuwachs der Buchen in den Reinbeständen aus. Korrelationsanalysen und die Anwendung linearer Mischeffekt-Regressionsmodelle zur Beschreibung des (funktionalen) Zusammenhangs zwischen Konkurrenz und absolutem Grundflächenzuwachs haben gezeigt, dass der TLS-basierte Index $\operatorname{CCSA}_{(\text {Cone })}$ die Zuwachsreaktion der untersuchten Buchen besser erklärt als ein auf geometrischen 
Kronenformen basierendes Konkurrenzmaß und somit zur Verbesserung des Verständnisses von Konkurrenzprozessen insbesondere in Mischbeständen beitragen kann.

Für eine weitere Studie wurden dendrochronologische Untersuchungen und Messungen des $\delta^{13} \mathrm{C}$-Signals im Holz der Jahrringe aller 24 'target trees ${ }^{6}$ kombiniert. Paarweise Mittelwertvergleiche innerhalb der drei Exploratorien haben ergeben, dass bezogen auf den Auswertungszeitraum 1970-2011 die Buchen aus Reinbeständen (z.T. signifikant) niedrigere durchschnittliche Radialzuwächse erreichten als Bäume, welche ausschließlich von gebietstypischen Mischbaumarten (Kiefer, Edellaubhölzer oder Fichte) umgeben waren. Dieses Grundmuster zeigte sich häufig auch während der extremen Trockenjahre 1976 und 2003, obwohl die wasserstressbedingten relativen Zuwachseinbrüche in Buchenreinbeständen i.d.R. schwächer ausgeprägt waren. Innerhalb des gleichen Untersuchungsgebietes erholten sich die Reinbestandsbuchen wiederum langsamer von den Zuwachseinbrüchen der Trockenjahre als das jeweilige Vergleichskollektiv, welches der Konkurrenz gebietstypischer Mischbaumarten ausgesetzt war. Die Ergebnisse der Jahrringanalyse und insbesondere die Bestimmung der Kohlenstoffisotopenverhältnisse im Holz deuteten somit im Falle von ausgeprägten Niederschlagsdefiziten, deren Häufigkeit mit fortschreitendem Klimawandel voraussichtlich zunehmen wird, auf eine verbesserte Wasserversorgung derjenigen Buchen hin, die von (konkurrenzschwächeren) Mischbaumarten umgeben waren (Kapitel 3).

Im Rahmen der dritten Teilstudie wurden über einen Zeitraum von zwei Jahren mittels elektronischer Dendrometer halbstündliche Änderungen des Stammumfanges an allen 24 'target trees' aufgezeichnet, um den Einfluss der Konkurrenzintensität und Nachbarschaftsidentität auf das intra-annuelle Dickenwachstum der Buche in unterschiedlicher zeitlicher Auflösung (Tag bis Jahr) zu betrachten (Kapitel 4). Nach Abschluss der Vegetationsperioden 2012 und 2013 lagen die prozentualen Grundflächenzuwächse der Buchen, die ausschließlich interspezifischer Konkurrenz durch gebietstypische Mischbaumarten ausgesetzt waren, ausnahmslos (jedoch nur teilweise signifikant) über jenen der Buchen in den Reinbeständen des gleichen Exploratoriums. Mittels einfacher linearer Regressionsanalysen ließ sich für beide Jahre ebenfalls ein signifikanter funktionaler Zusammenhang zwischen dem prozentualen Grundflächenzuwachs (= beobachtete, abhängige Variable) und dem Konkurrenzindex CCSA (= Prädiktor) nachweisen. Nach Standardisierung wurden durch Anpassung von Weibull-Funktionen an die kumulativen Zeitreihenwerte Funktionsparameter generiert, welche sich für gebietsinterne Analysen der unterjährigen Zuwachsverläufe von Buchen aus Rein- und Mischbeständen 
eigneten. Lediglich in Mischung mit Kiefer konnte eine im Vergleich zum Reinbestand des gleichen Gebietes (signifikante) Verlängerung des Dickenwachstums festgestellt werden. Nachbarschaftskonkurrenz durch Fichten oder Edellaubhölzer induzierte hingegen keinen gerichteten Effekt auf die zeitliche Ausnutzung der Vegetationsperiode. Es scheint, als würden potentiell positive Mischungseffekte auf die unterjährigen Zuwachsverläufe in Nachbarschaft mit Fichte und Edellaubhölzern von kleinräumlichen Standort- oder Witterungsunterschieden überlagert.

Die monatsweise Entwicklung der durchschnittlichen täglichen Zuwachsraten (in $\mu \mathrm{m}$ ) von Buchen mit intra- oder interspezifischer Nachbarschaft verlief innerhalb des jeweiligen Exploratoriums nahezu parallel. Allerdings konnten nur die Reinbestandsbuchen auf der Schwäbischen Alb regelmäßig die Tageszuwächse ihrer in Mischung mit Fichte wachsenden Artgenossen erreichen. In den beiden anderen Exploratorien war eine auf die (niedrigere) interspezifische Konkurrenz durch Kiefern oder Edellaubhölzer zurückzuführende diurnale Wuchsüberlegenheit der Buchen in Mischbeständen festzustellen. Dies lässt den Schluss zu, dass die intra-annuelle Wuchsdynamik primär der Kontrolle durch Umwelteinflüsse und standörtliche Bedingungen unterliegt. Artspezifische Mischungseffekte können sich positiv auf die täglichen Zuwachsraten der Buche auswirken, jedoch dominieren grundlegende Witterungs-Zuwachs-Beziehungen den Jahresgang des Dickenwachstums.

Zusammenfassend kann konstatiert werden, dass die Anfälligkeit der Baumart Buche gegenüber den mit dem Klimawandel einhergehenden Umweltveränderungen offensichtlich durch den von Nachbarbäumen ausgehenden Konkurrenzdruck und somit auch von der Artzugehörigkeit der Nachbarbäume beeinflusst wird. Die Ergebnisse der vorliegenden Studie legen nahe, dass der von Mischbaumarten auf die Buche ausgehende Konkurrenzdruck umso geringer ist, je stärker sich die Mischbaumarten in ihren funktionellen Eigenschaften von der Buche unterscheiden. Große funktionale Unterschiede wirken sich wiederum positiv auf das Ressourcenangebot, insbesondere auf die Wasserverfügbarkeit der Buche und in der Folge sowohl auf langfristige Zuwachsraten, als auch auf das Reaktionsvermögen im Falle von Trockenheitsereignissen aus. Die tatsächlichen Auswirkungen von Konkurrenzreduktion oder gegenseitiger Förderung durch Mischbaumarten auf das Wachstum und die Ressourcennutzung von Buchen sind jedoch von einem Faktorenkomplex abhängig. Neben der zeitlichen, räumlichen morphologischen oder physiologischen Nischenkomplementarität zwischen Buche und der jeweiligen Mischbaumart beeinflussen auch die standörtlichen sowie klimatischen Bedingungen bzw. die wachstumslimitierende Ressource selbst das 
Wuchsgeschehen. Nichtsdestotrotz kann die gezielte, vorzugsweise kleinräumliche Einbringung standortgerechter Mischbaumarten in Buchenreinbestände als probate waldbauliche Handlungsoption angesehen werden, um negative Auswirkungen des Klimawandels und häufigerer Trockenstressereignisse auf das Wachstum und die Vitalität der Rotbuche zu reduzieren. Dies ist selbstverständlich nicht nur aus forstwirtschaftlicher Sicht, respektive unter Nutzungsaspekten und im Zusammenhang mit dem betrieblichen Risikomanagement $\mathrm{zu}$ begrüßen, sondern kann auch für die dauerhafte Sicherung aller übrigen, grundsätzlich gleichrangigen Waldfunktionen von erheblicher Bedeutung sein. 
Chapter 1

\section{General Introduction}




\section{General Introduction}

\subsection{Scientific motivation}

The four representative concentration pathway scenarios (RCPs) presented in the fifth assessment report of the Intergovernmental Panel on Climate Change predict likely increases in global mean surface (air) temperature between 0.3 to $4.8^{\circ} \mathrm{C}$ by the end of the $21^{\text {st }}$ century (IPCC 2013). Apart from mean-trends, shifts in intra-annual thermal and precipitation regimes as well as higher frequencies of extreme weather events provide further evidence of an anthropogenically driven climate change (IPCC 2013). These recent shifts of growing conditions will have a significant effect on native and commercial forests (Kirilenko and Sedjo 2007). In some regions, positive impacts on tree growth can be expected (Nabuurs et al. 2002; Lindner et al. 2014). However, especially weather extremes such as droughts, heatwaves or heavy rainfalls which are likely to occur more often (Schär et al. 2004; Christensen et al. 2007; Seneviratne et al. 2012) impair productivity and vigor of trees respectively stands which leads to increased susceptibility for (mortality caused by) abiotic and biotic disturbances (Dale et al. 2001; Bolte et al. 2010; Allen et al. 2010; Lindner et al. 2010; Lévesque et al. 2014; Meir et al. 2015).

This also applies to European beech (Fagus sylvatica), a highly competitive tree species (Ellenberg 1996; Leuschner 1998) that covers a wide range of site conditions (Leuschner et al. 2006). Nevertheless, current scientific opinion concerning the drought tolerance of European beech is inconsistent. While some recently published studies consider vitality or growth of beech to be vulnerable to the expected increase in summer temperatures and drought frequency (e.g. Rennenberg et al. 2004; Czajkowski et al. 2005; Jump et al. 2006; Piovesan et al. 2008; Scharnweber et al. 2011; van der Maaten 2012; Zimmermann et al. 2015), other are less concerned and attest this tree species a strong adaptive capacity to climate change impacts (Dittmar et al. 2003; Ammer et al. 2005; Kölling et al. 2005 and 2007; Eichhorn et al. 2008; Fotelli et al. 2009; Metz et al. 2016). However, at present the relevance of European beech as one of the most important (commercial) tree species for Central European forestry remains unbroken (Ellenberg 1996; Tegel et al. 2014). Furthermore, European beech is accorded key significance in several national silviculture guidelines that promote transformation of pure coniferous stands into mixed forests with increasing proportions of deciduous tree species (von Lüpke et al. 2004; Ammer et al. 2008; Knoke et al. 2008; BMELV 2009). The establishment of multispecies forests does not only focus on economic considerations such as risk distribution based on diversification effects 
(Ammer et al. 2008; Knoke et al. 2008), but is expected to take better account of manifold demands on multifunctional forest management. These comprise timber production, carbon sequestration goals but also non-commercial forest functions like water and air pollution control, soil protection, nature conservation objectives and recreational use (Daily 1997; Bravo-Oviedo et al. 2014; Ammer 2017).

Sustainable management and long-term maintenance of various ecosystem services requires an adaption of forests to climate change based on keen knowledge derived from specific forest research (Bolte et al. 2010; Seidl et al. 2011; Ammer 2017). This is essential to establish objectives, minimize systemic risks, steer strategy implementation efforts and ensure social credibility (NW-FVA 2008). Ammer (2017) refers to two different options how forests themselves or foresters can react to recent and future climatic conditions: Either by (epi-) genetic species responses to environmental changes (Aitken et al. 2008; Bräutigam et al. 2013; Dounavi et al. 2016) or by silvicultural measures. However, small and separated populations, low fertility rates and late pubescence are common features of numerous commercial tree species that may restrict their ability for genetic adaption to climate change (Aitken et al. 2008; Ammer 2017). Thus, the first option is not a main object of this thesis and only mentioned here for the purpose of completeness.

According to Bolte et al. (2009) and Brang et al. (2014), (strategic) adaption principles should for instance aim at transformation of high-risk stands, increasing tree species richness, structural heterogeneity or genetic variation as well as restricting rotation length or timber stocks. The overarching goal of adaptive forest management is to perpetuate and enhance the functionality of forests as a precondition for providing the entire spectrum of potential future ecosystem services (Wagner 2004).

At the operational level (Brang et al. 2014), practical silvicultural interventions to prepare or adapt forests to (uncertainties resulting from) altering environmental conditions by increasing their resistance and resilience are limited (Bolte et al. 2010; Ammer 2017). Basically, most if not all (man-made) risk avoidance and management measures (Spittlehouse and Stewart 2003; Smit and Wandel 2006) are targeted towards reducing competition for resources among single trees (Ammer 2017) or within stands (Lebourgeois et al. 2013). In order to achieve the strategic goals mentioned before, forest practitioners can make use of two basic management options (Ammer 2017). First, stand density reductions through thinning that intends to lower competitive stress and enhance resource uptake as well as use efficiency of the remaining crop trees. Several studies conducted in (pure) stands of different tree species provided 
evidence, that thinning induces positive effects such as higher (stem) growth rates, prolonged growth durations (Boncina et al. 2007; van der Maaten 2013; Diaconu et al. 2015) or reduced water stress levels (i.a. in terms of improved drought resistance and resilience) due to higher water abundance or use efficiency (Aussenac and Granier 1988; Martín-Benito et al. 2010; Kohler et al. 2010; Sohn et al. 2013; Gebhardt et al. 2014; Sohn et al. 2016). Second, mixing of species with complementary functional traits and characteristics such as shade tolerance, crown morphology, leaf phenology or rooting habits that occupy different ecological niches (Vandermeer 1989; Kelty 1992; Lebourgeois et al. 2013).

Against the background of increasing proportions of mixed (beech) forests in Europe (Forest Europe, UNECE and FAO 2015) and the need to increase their climate resilience or adaptive capacity, this work examines the influence of neighborhood identity on tree growth responses of Fagus sylvatica L. at individual tree level what required additional measurements to gain detailed information on structural attributes of the surrounding competitors. In other words: Understanding competition in local neighborhoods could serve an important explanatory approach for stand or ecosystem productivity (Pretzsch and Schütze 2009; Riofrío et al. 2017; Fichtner et al. 2018) as the latter is the cumulative result of competition effects at the individual scale (Potvin and Dutilleul 2009) which are controlled by size, quantity and species composition of competitors in the immediate environment of a focal tree. Local neighborhoods are in turn affected by silvicultural interventions, as they control stand density or tree species composition.

Competition reduction and facilitation in interspecific neighborhoods (Vandermeer 1989; Kelty 1992 and 2006; Pretzsch and Schütze 2009; Forrester 2014; Forrester and Pretzsch 2015; Forrester and Bauhus 2016; Ammer 2019) are deemed to be the key mechanisms that induce higher tree growth rates or reduced drought susceptibility, also with regard to European beech (Pretzsch et al. 2010 \& 2013b; Mölder and Leuschner 2014; Metz et al. 2016). In a recently published review, Ammer (2019, p. 52) introduces the term 'relaxation' and proposes to subsume "[...] observed competition reduction and / or facilitation [...]" related to mixing effects under this concept. Enhanced availability, uptake and use efficiency of resources are the fundamental processes above- and belowground relaxation is based on (Forrester 2017; Ammer 2019). However, for various reasons studies dealing with the diversity-productivity relationship (at stand level) yielded contradicting results, indicating either enhanced productivity in multispecies forests (Piotto 2008; Pretzsch and Schütze 2009) or a lower growth performance of mixtures when compared to pure stands (Pretzsch 2005; 
Amoroso and Turnblom 2006; Jacob et al. 2010). On the one hand, processes inducing relaxation and subsequently (transgressive) overyielding are not a static state. They vary depending on site conditions (climate and soil), disturbances, stand development stage, stand density, functional traits of the tree species under investigation as well as the spatial or temporal scale of the survey (Pretzsch 2003; Forrester and Bauhus 2016; Ammer 2017; Mina et al. 2018; Ammer 2019). On the other hand, as a consequence of species specific responses to changing climate (Lindner et al. 2014) and thus diverse interdependencies between climate and competition (Rollinson et al. 2016), shifting growing conditions affect competition processes between species (Keenan 2015). Note that even the prediction of tree growth in even-aged monocultures by quantifying intraspecific competition is characterized by a considerable amount of unexplained variation. The major drivers of the much more complex species mixing effects are even more insufficiently understood (Jucker et al. 2015). However, among the numerous interacting factors that determine individual tree growth (Tomé and Burkhart 1989; Ledermann 2010), only competition can be cost-efficiently influenced by forest management interventions (Ammer 2008).

As (i.a. for European beech) neighborhood identity and/or mixture type instead of neighborhood diversity were found to determine complementarity effects such as reduced drought stress or enhanced growth rates (Jacob et al. 2010; Pretzsch et al. 2013b; Mölder and Leuschner 2014; Forrester et al. 2016; Metz et al. 2016; Ammer 2017; Mina et al. 2018), deeper insights into tree species interactions are essential to evaluate how species interdependencies may alter in view of climate change (Forrester 2014). At least in regularly managed commercial forests, this knowledge can serve as a valid basis of decision-making for adaption measures (e.g. choice of tree species, mixture types or thinning intensity) to climate change (Ammer 2017 and 2019). In other words: an increasing understanding of the effects of management measures on individual tree and stand level performance is necessary to better adjust silvicultural treatments to the challenges of climate change (Ammer 2017). 


\subsection{Objectives of the study}

The general objectives of the DFG-funded (Deutsche Forschungsgemeinschaft) large-scale and long-term research platform "Biodiversity Exploratories" are (cf. www.biodiversityexploratories.de):

- to understand the relationship between biodiversity of different taxa and levels

- to understand the impact of land use and management on biodiversity

- to understand the relevance of biodiversity for ecosystem processes

In order to disentangle interacting effects of land management measures and biodiversity on different ecosystem processes or services, since 2006 a multitude of core and contributing projects conduct interdisciplinary research on cause-and-effect relations in forest as well as grassland habitats (Fischer et al. 2010).

This $\mathrm{PhD}$ thesis focuses firstly on detecting growth-neighborhood responses of European beech on various time scales (day to year). Secondly it aims to relate the observed growth patterns of Fagus sylvatica target trees to the impact of intertree competition, neighborhood identity and different ecophysiological and morphological characteristics (plant traits). Therefore, this work deals with a key issue of the 'Biodiversity Exploratories': How do diversity, in this particular context 'neighborhood identity', and management intensity, here near natural pure stands compared to artificial mixed forests, affect ecosystem functions?

Picking up this highly-topical research subject, recent studies suggested that neighborhood dissimilarity or species identity of competitor trees (co-) determine growth and drought responses (resistance and resilience) of individual target trees or stands to a certain extent (e.g. Kaitaniemi and Lintunen 2010; Pretzsch et al. 2013b; Mölder and Leuschner 2014; Forrester et al. 2016; Fichtner et al. 2017). However, in many cases, key mechanisms were described mainly based on hypotheses (Pretzsch et al. 2015) rather than explained using quantitative data of intra- and interspecific competition or plant trait measurements (Kaitaniemi and Lintunen 2010).

In order to contribute to fill existing knowledge gaps in the field of mixed stand research, the main objectives of this study can be summarized as follows:

a) to measure the impact of competition intensity and neighborhood identity, which are both closely linked to silvicultural management interventions, on stem growth patterns of beech target trees at various time scales (day to year) 
b) to explain the revealed growth response of selected beech target trees as a function of their competitive neighborhood

c) to explain the revealed growth pattern by analyzing growth related ecophysiological and morphological plant traits such as stable isotope ratios or crown architecture

More specifically, in this study the following four hypotheses were examined:

1) One year basal area growth of target tree beeches does not depend on the magnitude of neighborhood competition they are exposed to.

2) (Intra-annual) basal area or radial growth of target tree beeches measured at different spatial scales and temporal resolutions does not depend on neighborhood identity (intraversus interspecific competition)

3) There is no difference in wood $\delta^{13} \mathrm{C}$-values of target tree beeches exposed to different competition intensities and neighborhood identities

4) There is no relationship between plant traits (e.g. wood $\delta^{13} \mathrm{C}$-values, crown surface areas) of target tree beeches and their radial or basal area stem growth.

Hypotheses one and two are addressed in the chapters two, three and four. In these chapters, various (site by site) comparisons of growth pattern on different time scales are presented as well as the growth responses of the target trees to different levels of competition intensity and different neighborhood identities. Hypotheses three and four were tested in chapter three which focuses on analyses of growth-related plant traits. 


\subsection{Study sites and experimental design}

Data collection for this thesis (cf. Metz et al. 2013, 2016 and 2019) was carried out on a subset of the 150 forest experimental plots (EPs) that are key elements the Biodiversity Exploratories study design (Fischer et al. 2010). The research sites were established in the Biosphere Reserves Swabian Alb (ALB / SW Germany) and Schorfheide-Chorin (SCH / NE Germany) as well as in the Hainich-Dün region (HAI / Central Germany). In each of these three 'Exploratories' that cover a wide environmental range (cf. Fig. 1.1), 50 forest field plots were set up. These plots represent wide gradients of management intensity and stand types, ranging from old growth forests to even-aged monocultures (Fischer et al. 2010).

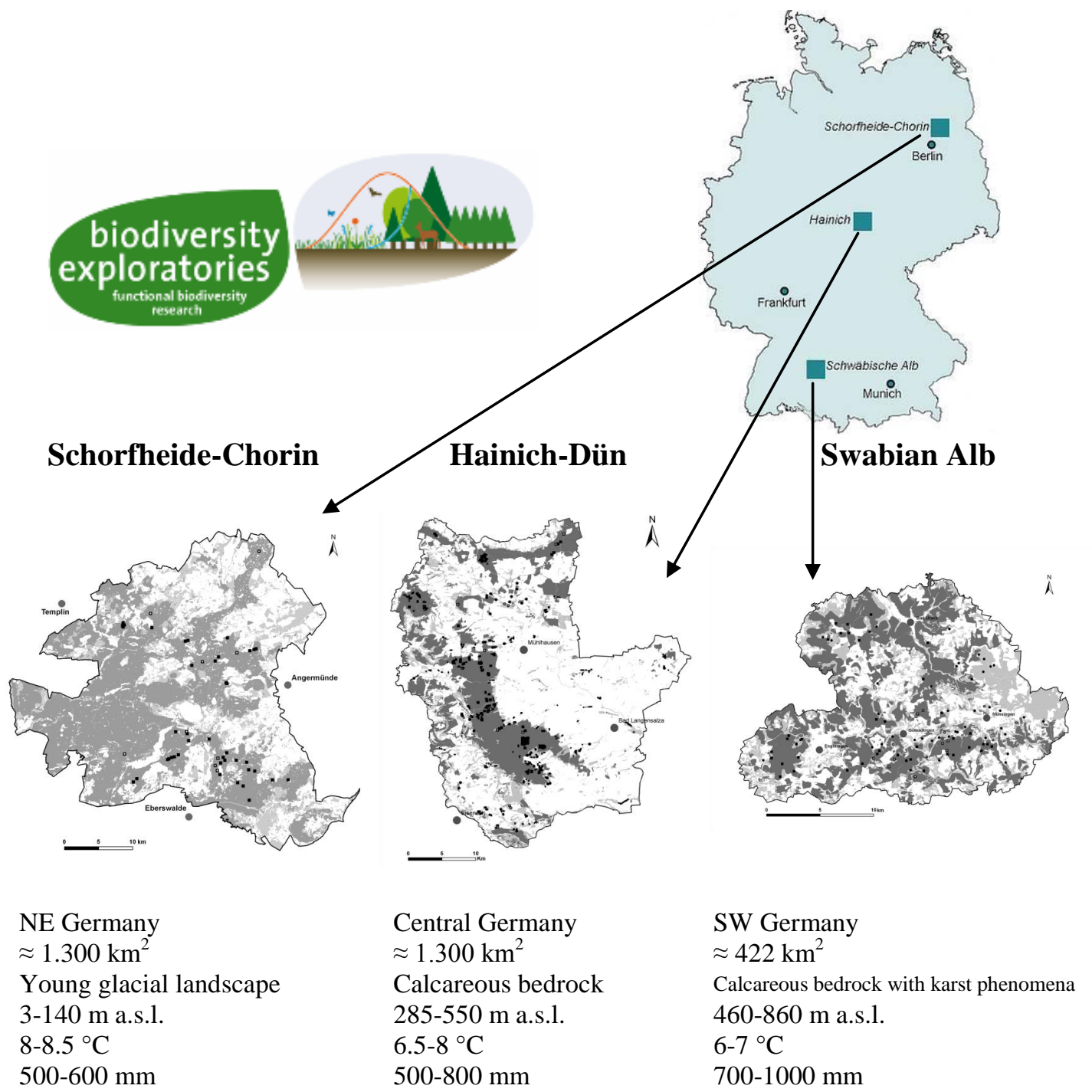

Central Germany
$\approx 1.300 \mathrm{~km}^{2}$
Calcareous bedrock
$285-550 \mathrm{~m}$ a.s.1.
$6.5-8^{\circ} \mathrm{C}$
$500-800 \mathrm{~mm}$

$700-1000 \mathrm{~mm}$

Fig. 1.1: Basic information on geographic locations and environmental conditions of the three Biodiversity Exploratories (cf. Fischer et al. 2010). 
A very important characteristic of the Biodiversity Exploratories project is that the analysis incorporates data from different major geographic regions of Germany. This, in turn, is a prerequisite to draw conclusions and to derive management recommendations with comprehensive geographic validity (Ammer et al. 2005; Fischer et al. 2010). The experimental set-up of the presented study (Table 1.1) was designed to evaluate the effect of initial size, competition intensity as well as identity of neighboring trees (and thus stand management) on growth pattern or ecophysiological characteristics of European beech target trees. Therefore, this study fully meets the demands for research exploring (intra-) annual increment of beech and its ability to overcome weather extremes in pure and mixed stands (Ammer et al. 2005; Bolte 2005; Mölder et al. 2011; van der Maaten 2012).

European beech (Fagus sylvatica) forms pure and mixed stands in all Exploratories, but as a consequence of differing climatic and edaphic conditions (cf. Fig. 1.1), the predominant cooccuring species vary between the large-scale research sites (see below). In each of the three Exploratories, eight uniformly arranged tree groups were selected (cf. Table 1.1). At every Exploratory, four tree groups were identified in pure European beech stands. In order to analyse the impact of interspecific competition on beech in regionally typical mixed stands, per region four additional target trees exclusively surrounded by the site-adapted admixed species (SCH: Pinus sylvestris; HAI: valuable hardwoods, mainly Acer pseudoplatanus or Fraxinus excelsior; ALB: Picea abies) were selected.

Table 1.1: Schematic presentation of and general information on the sampling design.

\begin{tabular}{|c|c|c|c|c|}
\hline sampling design & competitive situation & Exploratory & target trees & competitors \\
\hline & beech vs. beech & $\mathrm{SCH}$ & 4 & 16 \\
\hline & beech vs. pine & $\mathrm{SCH}$ & 4 & 16 \\
\hline & beech vs. beech & HAI & 4 & 16 \\
\hline & beech vs. val. hardwoods & HAI & 4 & 16 \\
\hline & beech vs. beech & ALB & 4 & 16 \\
\hline & beech vs. spruce & ALB & 4 & 16 \\
\hline & & & $\Sigma=24$ & $\Sigma=96$ \\
\hline
\end{tabular}

As downscaling to the individual tree level presupposes identical neighborhood densities in the competitive environment of a target tree (Ammer 2019), these twenty-four standardized tree clusters consisted of one central target beech tree symmetrically surrounded by exactly four either con- or allospecific competing neighbors $(\rightarrow$ three Exploratories $\mathrm{x}$ eight groups $\mathrm{x}$ five trees $=120$ trees). Another special characteristic of the sampling design (Table 1.1) 
conceived for this study is that all kinds of data were gathered from the same 24 tree groups (cf. Metz et al. 2013, 2016 and 2019).

While many studies that were focused on differences in stand productivity between pure and mixed beech forests (Pretzsch and Schütze 2009; Pretzsch et al. 2013a; Pretzsch et al. 2015) hypothesized which mechanisms or ecophysiological processes may have caused the observed growth reactions (Pretzsch et al. 2015), this study aims at unraveling cause-and-effect relationships for the growth response of individual target trees taking their particular competitive environment into account. 


\subsection{Measurement instrumentation}

In this study, not only retrospective analyses of yearly or periodic growth responses (cf. Mölder and Leuschner 2014; Pretzsch et al. 2015; Zimmermann et al. 2015) were used to address the objectives mentioned before. Instead, high-resolution measurements of current stem growth in beech target trees were also recorded. Moreover, these growth pattern were related with (measured instead of modeled) crown-competition indices and plant traits. For these purposes, the following (growth) attributes were analyzed, using state of the art techniques:

1) Competition-related stem growth patterns on different time scales of all 24 target beech trees

- Half-hourly stem circumference variation between March 2012 and October 2013 was monitored using electronic dendrometers (cf. chapters two and four; Metz et al. 2013 and 2019)
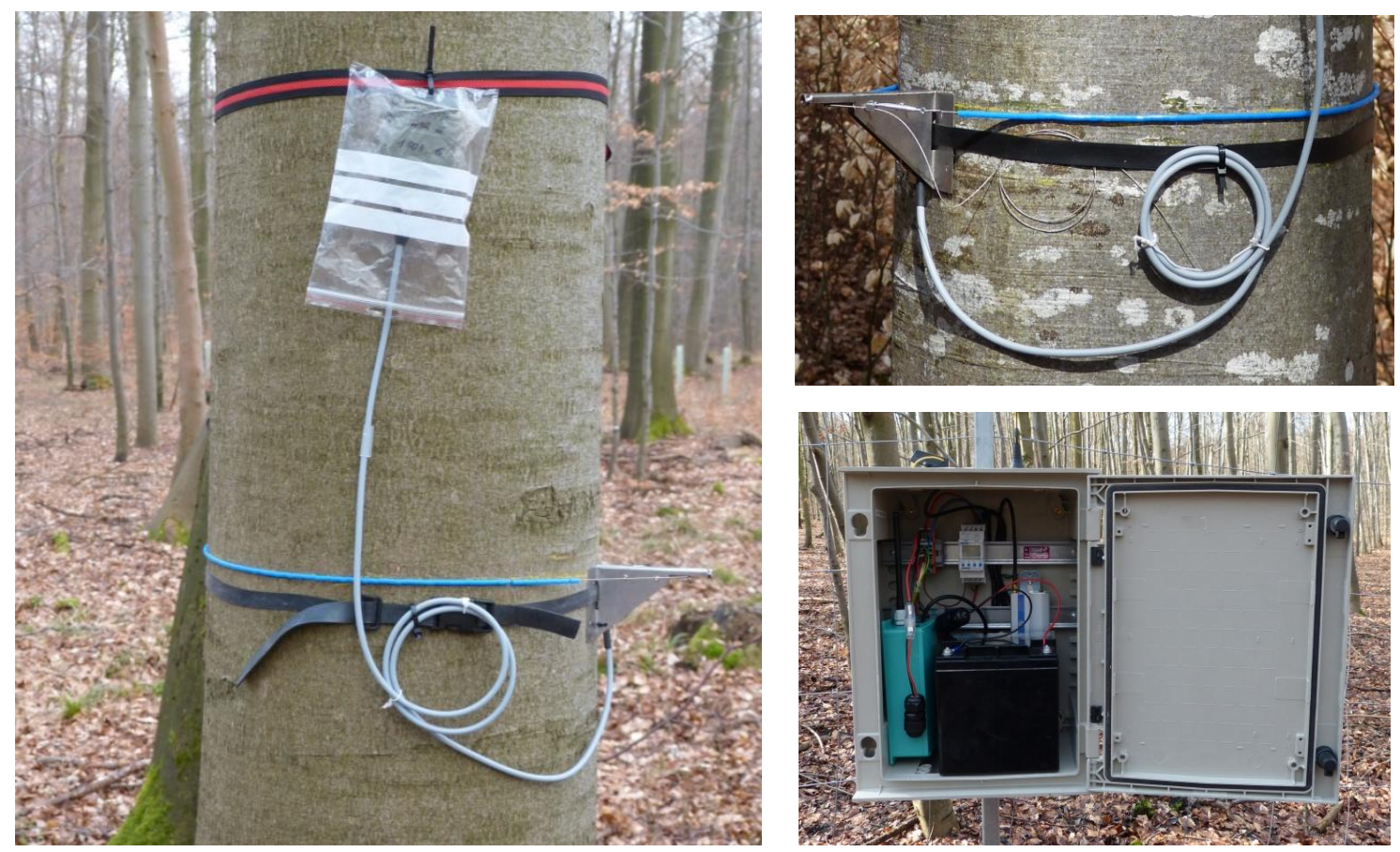

Fig. 1.2: Electronic self-acting DC2 circumference dendrometer with Scatter 100 sensor unit (left respectively top right) and Scatter 100 base station (bottom right).

- Tree-ring-widths covering the period 1970-2011 were measured on scanned stem core sample images and corresponding chronology statistics were computed (cf. chapter three; Metz et al. 2016)

- Measures for Resistance $\left(\mathrm{R}_{\mathrm{t}}\right)$, Recovery $\left(\mathrm{R}_{\mathrm{c}}\right)$ and Resilience $\left(\mathrm{R}_{\mathrm{s}}\right)$ were calculated on the basis of ring-width indices (RWIs) to investigate the impact of the exceptionally 
dry years 1976 and 2003 on stem increment of European beech (cf. chapter three; Metz et al. 2016)

2) Wood $\delta^{13} \mathrm{C}$-signature of all 24 target beech trees

- Measurements of tree-ring carbon isotopic composition during the 4-year periods 1975-1978 and 2002-2005 as an indicator for drought stress (cf. chapter three; Metz et al. 2016)
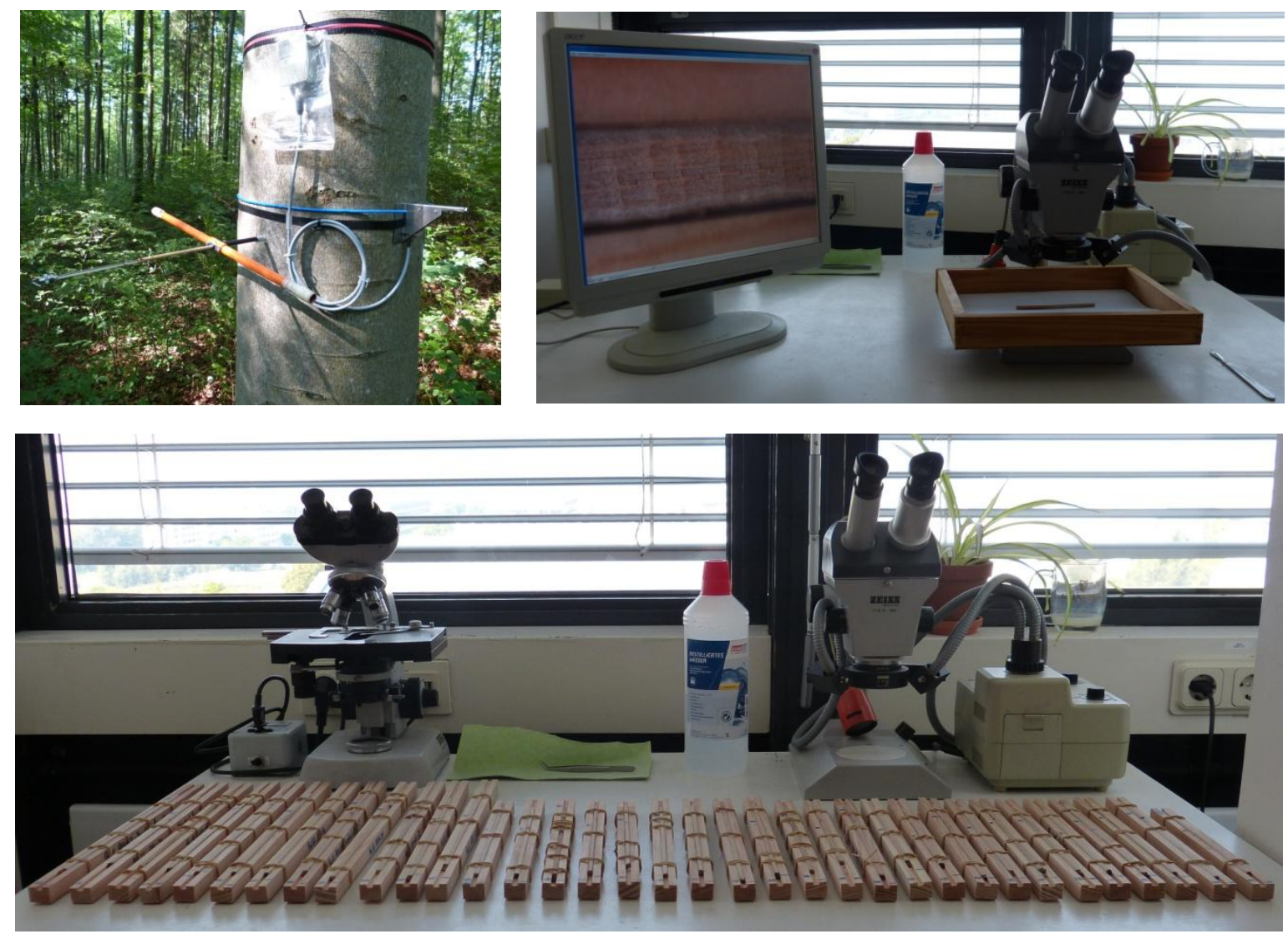

Fig. 1.3: Core sample extraction from a target beech tree (top left) and ready prepared increment cores for dendrochronological analysis (bottom and top right).

3) Structural stand attributes derived from terrestrial laser scans (TLS) of all 24 target beech trees and 96 competitors (cf. chapter two; Metz et al. 2013) were determined, including

- Total tree height (TTH)

- Diameter at breast height $(\mathrm{DBH})$

- Crown surface area (CSA)

- Crown volume (CV)

- Aboveground intra- and interspecific competition intensity (for the 24 target trees) 

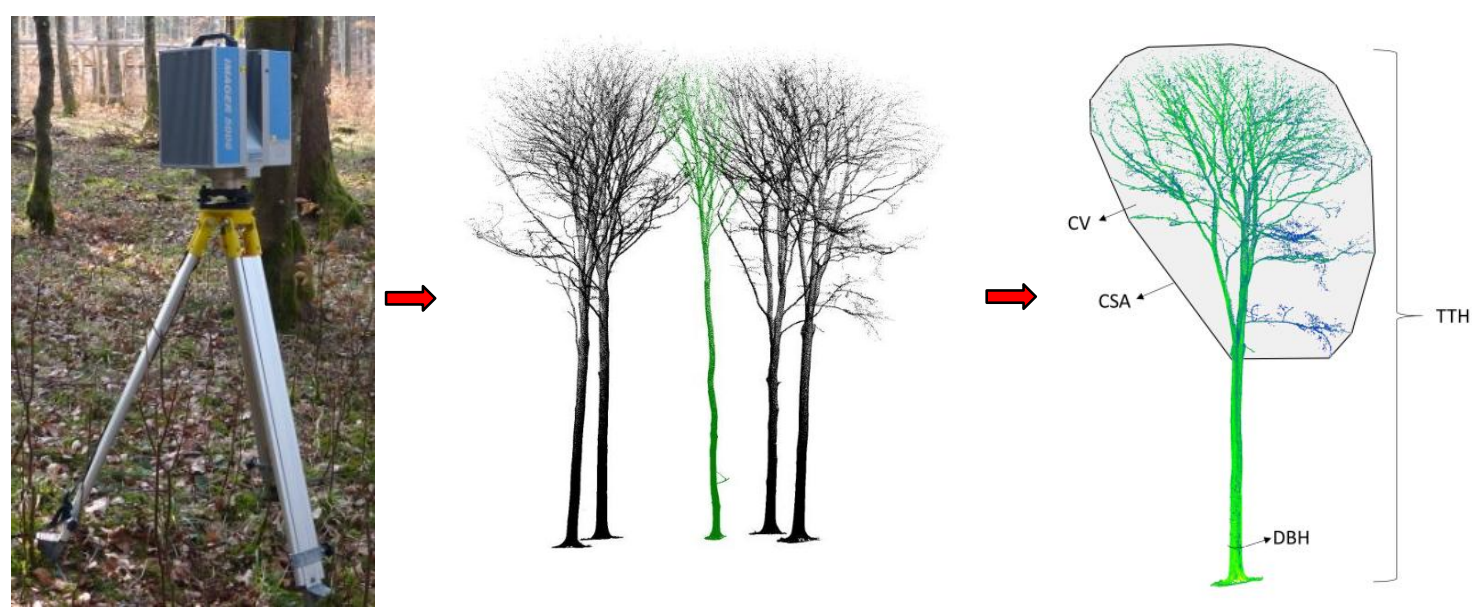

Fig. 1.4: Terrestrial laser scanner Zoller and Froehlich Imager 5006 (left), exemplary point cloud of a tree group generated from scanner data after 3D-measuring (middle) and structural tree parameters that were derived from voxel models (right). 


\subsection{References}

Aitken SN, Yeaman S, Holliday JA, Wang T, Curtis-McLane S (2008) Adaptation, migration or extirpation: climate change outcomes for tree populations. Evolutionary Applications $1: 95-111$.

Allen CD, Macalady AK, Chenchouni H, Bachelet D, McDowell N, Vennetier M, Kitzberger T, Rigling A, Breshears DD, Hogg EH, Gonzalez P, Fensham R, Zhang Z, Castro J, Demidova N, Lim J-H, Allard G, Running SW, Semerci A, Cobb N (2010) A global overview of drought and heat-induced tree mortality reveals emerging climate change risks for forests. Forest Ecology and Management 259:660-684.

Ammer C, Albrecht L, Borchert H, Brosinger F, Dittmar C, Elling W, Ewald J, Felbermeier B, von Gilsa H, Huss J, Kenk G, Kölling C, Kohnle U, Meyer P, Mosandl R, Moosmayer HU, Palmer S, Reif A, Rehfuess KE, Stimm B (2005) Future suitability of beech (Fagus sylvatica L.) in Central Europe: Critical remarks concerning a paper of Rennenberg et al. (2004). Allgemeine Forst- und Jagdzeitung 176:60-67

Ammer C, Bickel E, Kölling C (2008) Converting Norway spruce stands with beech - a review on arguments and techniques. Austrian Journal of Forest Science 125:3-26

Ammer C (2008) Konkurrenzsteuerung - Anmerkungen zu einer Kernaufgabe des Waldbaus beim Aufbau vielfältiger Wälder. In: Ministerium für ländliche Entwicklung, Umwelt und Verbraucherschutz (MLUV) des Landes Brandenburg (ed) Eberswalder Forstliche Schriftenreihe Band 36: Biologische Vielfalt - Lebensversicherung des Waldes, Eberswalde, pp 21-26

Ammer C (2017) Unraveling the Importance of Inter- and Intraspecific Competition for the Adaptation of Forests to Climate Change. In: Cánovas FM, Lüttge U, Matyssek R (eds) Progress in Botany Vol. 78. Springer International Publishing, Cham, Switzerland, pp 345-367

Ammer C (2019) Diversity and forest productivity in a changing climate. New Phytologist 221:50-66.

Amoroso MM, Turnblom EC (2006) Comparing productivity of pure and mixed Douglas-fir and western hemlock plantations in the Pacific Northwest. Canadian Journal of Forest Research 36:1484-1496. 
Aussenac G, Granier A (1988) Effects of thinning on water stress and growth in Douglas-fir. Canadian Journal of Forest Research 18:100-105.

BMELV (2009) Waldbericht der Bundesregierung 2009, Bundesministerium für Ernährung, Landwirtschaft und Verbraucherschutz (BMELV), Berlin

Bolte A (2005) Zur Zukunft der Buche in Mitteleuropa: Die klimatische Anpassungsfähigkeit der „Mutter des Waldes“. AFZ - Der Wald 60:1077-1078

Bolte A, Ammer C, Löf M, Madsen P, Nabuurs G-J, Schall P, Spathelf P, Rock J (2009) Adaptive forest management in central Europe: Climate change impacts, strategies and integrative concept. Scandinavian Journal of Forest Research 24:473-482.

Bolte A, Ammer C, Löf M, Nabuurs G-J, Schall P, Spathelf P (2010) Adaptive Forest Management: A Prerequisite for Sustainable Forestry in the Face of Climate Change. In: Spathelf P (ed) Sustainable Forest Management in a Changing World: A European Perspective, Managing Forest Ecosystems Vol 19. Springer Netherlands, Dordrecht, pp 115-139

Boncina A, Kadunc A, Robic D (2007) Effects of selective thinning on growth and development of beech (Fagus sylvatica L.) forest stands in south-eastern Slovenia. Annals of Forest Science 64:47-57.

Brang P, Spathelf P, Larsen JB, Bauhus J, Boncčìna A, Chauvin C, Drössler L, GarcíaGüemes C, Heiri C, Kerr G, Lexer MJ, Mason B, Mohren F, Mühlethaler U, Nocentini S, Svoboda M (2014) Suitability of close-to-nature silviculture for adapting temperate European forests to climate change. Forestry 87:492-503.

Bräutigam K, Vining KJ, Lafon-Placette C, Fossdal CG, Mirouze M, Marcos JG, Fluch S, Fraga MF, Guevara MÁ, Abarca D, Johnsen O, Maury S, Strauss SH, Campbell MM, Rohde A, Díaz-Sala C, Cervera M-T (2013) Epigenetic regulation of adaptive responses of forest tree species to the environment. Ecology and Evolution 3:399-415.

Bravo-Oviedo A, Pretzsch H, Ammer C, Andenmatten E, Barbati A, Barreiro S, Brang P, Bravo F, Coll L, Corona P, den Ouden J, Ducey MJ, Forrester DI, Giergiczny M, Jacobsen JB:, Lesinski J, Löf M, Mason B, Matović B, Metslaid M, Morneau F, Motiejunaite J, O'Reilly C, Pach M, Ponette Q, del Rio M, Short I, Skovsgaard JP, Soliño M, Spathelf P, Sterba H, Stojanovic D, Strelcova K, Svoboda M, Verheyen K, von Lüpke N, Zlatanov T (2014) European Mixed Forests: definition and research perspectives. Forest Systems 23:518-533. 
Christensen JH, Hewitson B, Busuioc A, Chen A, Gao X, Held I, Jones R, Kolli RK, Kwon W-T, Laprise R, Magaña Rueda V, Mearns L, Menéndez CG, Räisänen J, Rinke A, Sarr A and Whetton P (2007) Regional Climate Projections. In: Solomon S, Qin D, Manning M, Chen Z, Marquis M, Averyt KB, Tignor M and Miller HL (eds) Climate Change 2007: The Physical Science Basis. Contribution of Working Group I to the Fourth Assessment Report of the Intergovernmental Panel on Climate Change. Cambridge University Press, Cambridge, United Kingdom and New York, NY, USA

Czajkowski T, Kühling M, Bolte A (2005) Impact of the 2003 summer drought on growth of beech sapling natural regeneration (Fagus sylvatica L.) in north-eastern Central Europe. Allgemeine Forst- und Jagdzeitung 176:133-143

Daily GC (1997) Nature's services: societal dependence on natural ecosystems. Island Press, Washington, DC

Dale VH, Joyce LA, McNulty S, Neilson RP, Ayres MP, Flannigan MD, Hanson PJ, Irland LC, Lugo AE, Peterson CJ, Simberloff D, Swanson FJ, Stocks BJ, Wotton BM (2001) Climate Change and Forest Disturbances. BioScience 51:723-734

Diaconu D, Kahle H-P, Spiecker H (2015) Tree- and Stand-Level Thinning Effects on Growth of European Beech (Fagus sylvatica L.) on a Northeast- and a Southwest-Facing Slope in Southwest Germany. Forests 6:3256-3277.

Dittmar C, Zech W, Elling W (2003) Growth variations of Common beech (Fagus sylvatica L.) under different climatic and environmental conditions in Europe-a dendroecological study. Forest Ecology and Management 173:63-78.

Dounavi A, Netzer F, Celepirovic N, Ivanković M, Burger J, Figueroa AG, Schön S, Simon J, Cremer E, Fussi B, Konnert M, Rennenberg H (2016) Genetic and physiological differences of European beech provenances ( $F$. sylvatica L.) exposed to drought stress. Forest Ecology and Management 361:226-236.

Eichhorn J, Dammann I, Schönfelder E, Albrecht M, Beck W, Paar U (2008) Untersuchungen zur Trockenheitstoleranz der Buche am Beispiel des witterungsextremen Jahres 2003: Assessment of the drought resistance of beech exemplified by the 2003 extreme weather conditions. In: NW-FVA (ed) Ergebnisse angewandter Forschung zur Buche: Beiträge aus der Nordwestdeutschen Forstlichen Versuchsanstalt Band 3. Universitätsverlag Göttingen, Göttingen, pp 109-134 
Ellenberg H (1996) Vegetation Mitteleuropas mit den Alpen in ökologischer, dynamischer und historischer Sicht. 170 Tabellen. Ulmer, Stuttgart, 1095 S.

Fichtner A, Härdtle W, Li Y, Bruelheide H, Kunz M, von Oheimb G (2017) From competition to facilitation: how tree species respond to neighbourhood diversity. Ecology Letters 20:892-900.

Fichtner A, Härdtle W, Bruelheide H, Kunz M, Li Y, von Oheimb G (2018) Neighbourhood interactions drive overyielding in mixed-species tree communities. Nature Communications 9:1144.

Fischer M, Bossdorf O, Gockel S, Hänsel F, Hemp A, Hessenmöller D, Korte G, Nieschulze J, Pfeiffer S, Prati D, Renner S, Schöning I, Schumacher U, Wells K, Buscot F, Kalko EKV, Linsenmair KE, Schulze E-D, Weisser WW (2010) Implementing large-scale and long-term functional biodiversity research: The Biodiversity Exploratories. Basic and Applied Ecology 11:473-485.

Forest Europe, UNECE and FAO (2015) State of Europe's Forests 2015: Summary for Policy Makers. (MCPFE, FOREST EUROPE Liaison Unit Madrid, Spain: 2015)

Forrester DI (2014) The spatial and temporal dynamics of species interactions in mixedspecies forests: From pattern to process. Forest Ecology and Management 312:282-292.

Forrester DI (2017) Ecological and Physiological Processes in Mixed Versus Monospecific Stands. In: Pretzsch H, Forrester DI, Bauhus J (eds) Mixed-Species Forests: Ecology and Management. Springer Berlin Heidelberg, Berlin, Heidelberg, pp 73-115

Forrester DI, Bauhus J (2016) A Review of Processes Behind Diversity--Productivity Relationships in Forests. Current Forestry Reports 2:45-61.

Forrester DI, Pretzsch H (2015) Tamm Review: On the strength of evidence when comparing ecosystem functions of mixtures with monocultures. Forest Ecology and Management $356: 41-53$.

Forrester DI, Bonal D, Dawud S, Gessler A, Granier A, Pollastrini M, Grossiord C (2016) Drought responses by individual tree species are not often correlated with tree species diversity in European forests. Journal of Applied Ecology 53:1725-1734.

Fotelli MN, Nahm M, Radoglou K, Rennenberg H, Halyvopoulos G, Matzarakis A (2009) Seasonal and interannual ecophysiological responses of beech (Fagus sylvatica) at its 
south-eastern distribution limit in Europe. Forest Ecology and Management 257:11571164.

Gebhardt T, Häberle K-H, Matyssek R, Schulz C, Ammer C (2014) The more, the better? Water relations of Norway spruce stands after progressive thinning. Agricultural and Forest Meteorology 197:235-243.

IPCC (2013) Summary for Policymakers. In: Stocker TF, Qin D, Plattner G-K, Tignor M, Allen SK, Boschung J, Nauels A, Xia Y, Bex V, Midgley PM (eds) Climate Change 2013: The Physical Science Basis.: Contribution of Working Group I to the Fifth Assessment Report of the Intergovernmental Panel on Climate Change. Cambridge University Press, Cambridge, United Kingdom and New York, NY, USA, pp 3-29

Jacob M, Leuschner C, Thomas FM (2010) Productivity of temperate broad-leaved forest stands differing in tree species diversity. Annals of Forest Science 67:503.

Jucker T, Bouriaud O, Coomes DA (2015) Crown plasticity enables trees to optimize canopy packing in mixed-species forests. Functional Ecology 29:1078-1086.

Jump AS, Hunt JM, Penuelas J (2006) Rapid climate change-related growth decline at the southern range edge of Fagus sylvatica. Global Change Biology 12:2163-2174.

Kaitaniemi P, Lintunen A (2010) Neighbor identity and competition influence tree growth in Scots pine, Siberian larch, and silver birch. Annals of Forest Science 67:604.

Keenan RJ (2015) Climate change impacts and adaptation in forest management: a review. Annals of Forest Science 72:145-167.

Kelty MJ (1992) Comparative productivity of monocultures and mixed-species stands. In: Kelty MJ, Larson BC, Oliver CD (eds) The Ecology and Silviculture of Mixed-Species Forests, vol 40. Kluwer Academic Publishers, Dordrecht, pp 125-141

Kelty MJ (2006) The role of species mixtures in plantation forestry. Forest Ecology and Management 233:195-204.

Kirilenko AP, Sedjo RA (2007) Climate change impacts on forestry. Proceedings of the National Academy of Sciences 104:19697-19702.

Knoke T, Ammer C, Stimm B, Mosandl R (2008) Admixing broadleaved to coniferous tree species: a review on yield, ecological stability and economics. European Journal of Forest Research 127:89-101. 
Kohler M, Sohn J, Nägele G, Bauhus J (2010) Can drought tolerance of Norway spruce (Picea abies (L.) Karst.) be increased through thinning? European Journal of Forest Research 129:1109-1118.

Kölling C, Walentowski H, Borchert H (2005) Die Buche in Mitteleuropa: Eine Waldbaumart mit grandioser Vergangenheit und sicherer Zukunft. AFZ - Der Wald 60:696-701

Kölling C, Zimmermann L, Walentowski H (2007) Klimawandel: Was geschieht mit Buche und Fichte. AFZ - Der Wald 62:584-588

Lebourgeois F, Gomez N, Pinto P, Mérian P (2013) Mixed stands reduce Abies alba tree-ring sensitivity to summer drought in the Vosges mountains, western Europe. Forest Ecology and Management 303:61-71.

Ledermann T (2010) Evaluating the performance of semi-distance-independent competition indices in predicting the basal area growth of individual trees. Canadian Journal of Forest Research 40:796-805.

Leuschner C (1998) Mechanismen der Konkurrenzüberlegenheit der Rotbuche. In: Berichte der Reinhold-Tüxen-Gesellschaft (RTG), vol 10, pp 5-18

Leuschner C, Meier IC, Hertel D (2006) On the niche breadth of Fagus sylvatica: Soil nutrient status in 50 Central European beech stands on a broad range of bedrock types. Annals of Forest Science 63:355-368.

Lévesque M, Rigling A, Bugmann H, Weber P, Brang P (2014) Growth response of five cooccurring conifers to drought across a wide climatic gradient in Central Europe. Agricultural and Forest Meteorology 197:1-12.

Lindner M, Maroschek M, Netherer S, Kremer A, Barbati A, Garcia-Gonzalo J, Seidl R, Delzon S, Corona P, Kolström M, Lexer MJ, Marchetti M (2010) Climate change impacts, adaptive capacity, and vulnerability of European forest ecosystems. Forest Ecology and Management 259:698-709.

Lindner M, Fitzgerald JB, Zimmermann NE, Reyer C, Delzon S, van der Maaten E, Schelhaas M-J, Lasch P, Eggers J, van der Maaten-Theunissen M, Suckow F, Psomas A, Poulter B, Hanewinkel M (2014) Climate change and European forests: What do we know, what are the uncertainties, and what are the implications for forest management? Journal of Environmental Management 146:69-83. 
Martín-Benito D, Del Río M, Heinrich I, Helle G, Cañellas I (2010) Response of climategrowth relationships and water use efficiency to thinning in a Pinus nigra afforestation. Forest Ecology and Management 259:967-975.

Meir P, Mencuccini M, Dewar RC (2015) Drought-related tree mortality: addressing the gaps in understanding and prediction. New Phytologist 207:28-33.

Metz J, Annighöfer P, Westekemper K, Schall P, Schulze E-D, Ammer C (2019) Less is more: Effects of competition reduction and facilitation on intra-annual (basal area) growth of mature European beech. Trees, DOI:10.1007/s00468-019-01894-7.

Metz J, Seidel D, Schall P, Scheffer D, Schulze E-D, Ammer C (2013) Crown modeling by terrestrial laser scanning as an approach to assess the effect of aboveground intra- and interspecific competition on tree growth. Forest Ecology and Management 310:275-288.

Metz J, Annighöfer P, Schall P, Zimmermann J, Kahl T, Schulze E-D, Ammer C (2016) Siteadapted admixed tree species reduce drought susceptibility of mature European beech. Global Change Biology 22:903-920.

Mina M, Huber MO, Forrester DI, Thürig E, Rohner B (2018) Multiple factors modulate tree growth complementarity in Central European mixed forests. Journal of Ecology 106:1106-1119.

Mölder I, Leuschner C (2014) European beech grows better and is less drought sensitive in mixed than in pure stands: tree neighbourhood effects on radial increment. Trees 28:777792.

Mölder I, Leuschner C, Leuschner HH (2011) $\delta^{13} \mathrm{C}$ signature of tree rings and radial increment of Fagus sylvatica trees as dependent on tree neighborhood and climate. Trees 25:215-229.

Nabuurs G-J, Pussinen A, Karjalainen T, Erhard M, Kramer K (2002) Stemwood volume increment changes in European forests due to climate change-a simulation study with the EFISCEN model. Global Change Biology 8:304-316.

NW-FVA (ed) (2008) Ergebnisse angewandter Forschung zur Buche: Beiträge aus der Nordwestdeutschen Forstlichen Versuchsanstalt Band 3. Universitätsverlag Göttingen, Göttingen

Piotto D (2008) A meta-analysis comparing tree growth in monocultures and mixed plantations. Forest Ecology and Management 255:781-786. 
Piovesan G, Biondi F, Di Filippo A, Alessandrini A, Maugeri M (2008) Drought-driven growth reduction in old beech (Fagus sylvatica L.) forests of the central Apennines, Italy. Global Change Biology 14: 1265-1281.

Potvin C, Dutilleul P (2009) Neighborhood effects and size-asymmetric competition in a tree plantation varying in diversity. Ecology 90: 321-327.

Pretzsch H (2003) Diversität und Produktivität von Wäldern. Allgemeine Forst- und Jagdzeitung 174: 88-98

Pretzsch H (2005) Diversity and Productivity in Forests: Evidence from Long-Term Experimental Plots. In: Scherer-Lorenzen, M., Körner, Ch., Schulze, E.-D. (eds) Forest Diversity and Function: Temperate and Boreal Systems, vol 176. Springer-Verlag, Berlin, Heidelberg, pp 41-64

Pretzsch H, Schütze G (2009) Transgressive overyielding in mixed compared with pure stands of Norway spruce and European beech in Central Europe: evidence on stand level and explanation on individual tree level. European Journal of Forest Research 128: 183204.

Pretzsch H, Block J, Dieler J, Dong PH, Kohnle U, Nagel J, Spellmann H, Zingg A (2010) Comparison between the productivity of pure and mixed stands of Norway spruce and European beech along an ecological gradient. Annals of Forest Science 67: 712.

Pretzsch H, Bielak K, Block J, Bruchwald A, Dieler J, Ehrhart H-P, Kohnle U, Nagel J, Spellmann H, Zasada M, Zingg A (2013a) Productivity of mixed versus pure stands of oak (Quercus petraea (Matt.) Liebl. and Quercus robur L.) and European beech (Fagus sylvatica L.) along an ecological gradient. European Journal of Forest Research 132: 263-280.

Pretzsch H, Schütze G, Uhl E (2013b) Resistance of European tree species to drought stress in mixed versus pure forests: evidence of stress release by inter-specific facilitation. Plant Biology 15: 483-495.

Pretzsch H, del Río M, Ammer C, Avdagic A, Barbeito I, Bielak K, Brazaitis G, Coll L, Dirnberger G, Drössler L, Fabrika M, Forrester DI, Godvod K, Heym M, Hurt V, Kurylyak V, Löf M, Lombardi F, Matović B, Mohren F, Motta R, den Ouden J, Pach M, Ponette Q, Schütze G, Schweig J, Skrzyszewski J, Sramek V, Sterba H, Stojanović D, Svoboda M, Vanhellemont M, Verheyen K, Wellhausen K, Zlatanov T, Bravo-Oviedo A (2015) Growth and yield of mixed versus pure stands of Scots pine (Pinus sylvestris L.) 
and European beech (Fagus sylvatica L.) analysed along a productivity gradient through Europe. European Journal of Forest Research 134: 927-947.

Rennenberg H, Seiler W, Matyssek R, Geßler A, Kreuzwieser J (2004) Die Buche (Fagus sylvatica L.) - ein Waldbaum ohne Zukunft im südlichen Mitteleuropa?: European beech (Fagus sylvatica L.)-a forest tree without future in the south of Central Europe? Allgemeine Forst- und Jagdzeitung: 210-244

Riofrío J, Del Río M, Bravo F (2017) Mixing effects on growth efficiency in mixed pine forests. Forestry 90: 381-392.

Rollinson CR, Kaye MW, Canham CD (2016) Interspecific variation in growth responses to climate and competition of five eastern tree species. Ecology 97: 1003-1011.

Schär C, Vidale PL, Lüthi D, Frei C, Häberli C, Liniger MA, Appenzeller C (2004) The role of increasing temperature variability in European summer heatwaves. Nature 427: 332336.

Scharnweber T, Manthey M, Criegee C, Bauwe A, Schröder C, Wilmking M (2011) Drought matters - Declining precipitation influences growth of Fagus sylvatica L. and Quercus robur L. in north-eastern Germany. Forest Ecology and Management 262: 947-961.

Seidl R, Rammer W, Lexer MJ (2011) Adaptation options to reduce climate change vulnerability of sustainable forest management in the Austrian Alps. Canadian Journal of Forest Research 41: 694-706.

Seneviratne SI, Nicholls N, Easterling D, Goodess CM, Kanae S, Kossin J, Luo Y, Marengo J, McInnes K, Rahimi M, Reichstein M, Sorteberg A, Vera C, Zhang X et al. (2012) Changes in climate extremes and their impacts on the natural physical environment. In: Field CB, Barros V, Stocker TF, Qin D, Dokken DJ, Ebi KL, Mastrandrea MD, Mach KJ, Plattner G.-K., Allen SK, Tignor M, Midgley PM (eds) Managing the Risks of Extreme Events and Disasters to Advance Climate Change Adaptation: A Special Report of Working GroupsI and II of the Intergovernmental Panel on Climate Change (IPCC). Cambridge University Press, Cambridge, UK, and New York, NY, USA, pp 109-230.

Smit B, Wandel J (2006) Adaptation, adaptive capacity and vulnerability. Global Environmental Change 16:282-292.

Sohn JA, Gebhardt T, Ammer C, Bauhus J, Häberle K-H, Matyssek R, Grams TEE (2013) Mitigation of drought by thinning: Short-term and long-term effects on growth and 
physiological performance of Norway spruce (Picea abies). Forest Ecology and Management 308: 188-197.

Sohn JA, Saha S, Bauhus J (2016) Potential of forest thinning to mitigate drought stress: A meta-analysis. Forest Ecology and Management 380: 261-273.

Solly E, Schöning I, Boch S, Müller J, Socher SA, Trumbore SE, Schrumpf M (2013) Mean age of carbon in fine roots from temperate forests and grasslands with different management. Biogeosciences. 10: 4833-4843.

Spittlehouse DL, Stewart RB (2003) Adaptation to climate change in forest management. British Columbia Journal of Ecosystems and Management 4: 1-11

Tegel W, Seim A, Hakelberg D, Hoffmann S, Panev M, Westphal T, Büntgen U (2014) A recent growth increase of European beech (Fagus sylvatica L.) at its Mediterranean distribution limit contradicts drought stress. European Journal of Forest Research 133: $61-71$.

Tomé M, Burkhart HE (1989) Distance-Dependent Competition Measures for Predicting Growth of Individual Trees. Forest Science 35: 816-831.

van der Maaten E (2012) Climate sensitivity of radial growth in European beech (Fagus sylvatica L.) at different aspects in southwestern Germany. Trees 26: 777-788.

van der Maaten E (2013) Thinning prolongs growth duration of European beech (Fagus sylvatica L.) across a valley in southwestern Germany. Forest Ecology and Management 306: $135-141$.

Vandermeer JH (1989) The ecology of intercropping. Cambridge University Press, Cambridge [England], New York

von Lüpke B, Ammer C, Braciamacchie M, Brunner A, Ceitel J, Collet C, Deuleuze C, Di Placido J, Huss J, Jankovic J, Kantor P, Larsen J, Lexer M, Löf M, Longauer R, Madsen P, Modrzynski J, Mosandl R, Pampe A, Zientarski J (2004) Silvicultural strategies for conversion. In: Spiecker H, Hansen J, Klimo E, Skovsgaard J, Sterba H, von Teuffel K (eds) Norway spruce conversion - options and consequences. Brill, Leiden, Netherlands, pp 121-164

Wagner S (2004) Möglichkeiten und Beschränkungen eines funktionsorientierten Waldbaus. Forst und Holz 59: 105-111 
Zimmermann J, Hauck M, Dulamsuren C, Leuschner C (2015) Climate Warming-Related Growth Decline Affects Fagus sylvatica, But Not Other Broad-Leaved Tree Species in Central European Mixed Forests. Ecosystems 18: 560-572. 


\title{
Chapter 2
}

Crown modeling by terrestrial laser scanning as an approach to assess the effect of aboveground intra- and interspecific competition on tree growth

\author{
Jérôme Metz • Dominik Seidel • Peter Schall • Dina Scheffer \\ - Ernst-Detlef Schulze • Christian Ammer
}

\author{
Reprinted by permission from Elsevier B.V. \\ Journal publisher: Elsevier \\ Journal name: Forest Ecology and Management
}

Article name: Crown modeling by terrestrial laser scanning as an approach to assess the effect of aboveground intra- and interspecific competition on tree growth Authors: Metz J, Seidel D, Schall P, Scheffer D, Schulze E-D, Ammer C Copyright: Elsevier B.V. 2013

Year of publication: 2013

Doi: 10.1016/j.foreco.2013.08.014

Forest Ecol Manag

The final publication is available at:

https://www.sciencedirect.com/science/article/abs/pii/S0378112713005410 


\title{
Crown modeling by terrestrial laser scanning as an approach to assess the effect of aboveground intra- and interspecific competition on tree growth
}

\author{
Jérôme Metz ${ }^{\mathrm{a}, *}$, Dominik Seidel ${ }^{\mathrm{a}}$, Peter Schall ${ }^{\mathrm{a}}$, Dina Scheffer ${ }^{\mathrm{a}}$, Ernst-Detlef Schulze ${ }^{\mathrm{b}}$, Christian Ammer ${ }^{a}$ \\ ${ }^{a}$ Department of Silviculture and Forest Ecology of the Temperate Zones, Faculty of Forest Sciences and Forest Ecology, University of Göttingen, Büsgenweg 1, 37077 Göttingen, Germany \\ ${ }^{\mathrm{b}}$ Max-Planck-Institute for Biogeochemistry, Hans-Knoell-Straße 10, 07745 Jena, Germany
}

\section{A R T I C L E I N F O}

\section{Article history:}

Received 22 April 2013

Received in revised form 13 July 2013

Accepted 9 August 2013

Available online $\mathrm{xxxx}$

\section{Keywords:}

Beech

Competition

Search cone

Terrestrial laser scanning

Point cloud

\begin{abstract}
A B S T R A C T
Individual tree growth is controlled by numerous factors, but intertree competition is of special importance as it is the only parameter that can be managed by silvicultural measures. Many indices dealing with aboveground interference use geometric standard crown shapes to quantify the competitive strength of neighbors on the target tree. As such crowns do not realistically represent the spatial heterogeneity in the canopy, a terrestrial laser scanner was used to gain detailed information on crown characteristics which may be used for a more precise modeling of the relationship between competition and growth. We examined groups of 5 trees growing in three major geographic regions of Germany to investigate the effect of intra- and interspecific competition for light on basal area growth of target beech trees (Fagus sylvatica). A competition index based on individual crown shapes derived from TLS-data correlated better with target tree growth than an index using conventional geometric crown shape models. Both measures ascribed the highest competitive strength to intraspecific competition. In contrast to the valuable hardwoods for which a slightly lower crown competition was calculated, the conifer species Norway spruce (Picea abies) and Scots pine (Pinus sylvestris) had considerably weaker competitive effects on beech. The growth response of the investigated target trees reflected the strength in competition (highest relative basal area growth of beech if mixed with Scots pine $>$ Norway spruce $>$ valuable hardwoods > intraspecific competition) even though the increment measurements with self-acting dendrometers covered only one vegetation period. Neighborhood diversity and target tree growth were correlated, indicating stronger effects of intra- compared to interspecific interference. The utilization of a terrestrial laser scanner provided insights into canopy structure of the competitive neighborhood that may enhance our understanding of competitive interactions.
\end{abstract}

(c) 2013 Elsevier B.V. All rights reserved.

\section{Introduction}

Over the last 4 decades, devastating calamities, the proceeding climate change and modified requirements for a multifunctional forestry resulted in a fundamental rethinking of silvicultural treatments. Through joint efforts of scientists and forest administrations, the conversion of pure into mixed stands was put into practice and increased the portion of mixed forests in Europe (Ammer et al., 2008; Knoke et al., 2008). This is seen as an opportunity to develop management strategies that are more sustainable from an ecologic and economic point of view (Filipescu and Comeau, 2007; Knoke et al., 2008). As an outcome of this trend, manifold forest ecosystem coherences and especially growth dynamics in mixed stands have to be restudied (Bartelink, 2000; Perot et al., 2010; Zhao et al., 2006).

\footnotetext{
* Corresponding author. Tel.: +495513919679.

E-mail address: jmetz@gwdg.de (J. Metz).
}

0378-1127/\$ - see front matter @ 2013 Elsevier B.V. All rights reserved. http://dx.doi.org/10.1016/j.foreco.2013.08.014
Individual tree growth, be it in pure or mixed stands, is affected by a combination of multiple factors, including climate, site conditions, ontogenetic stage and competition processes (Ledermann, 2010; Shi and Zhang, 2003; Tomé and Burkhart, 1989). Among all of them, competition is of special importance as it is the only factor that can be cost-efficiently influenced by silviculture (Ammer, 2008). Up to now, several unknown environmental effects make it difficult to quantify the competitive effect of neighboring trees (Barclay and Layton, 1990; Larocque, 2002). This applies to even-aged monocultures and in a much more complex dimension to mixed stands. Competition in plant communities means, that one individual impacts the viability or growth of another one (Townsend et al., 2003). Furthermore, the effect of competitors on the growth response of a tree in a mixed stand is not independent from species identity of the competing neighbors (Canham et al., 2004; Pretzsch and Schütze, 2009; Zhao et al., 2006). With regard to aboveground competition, it has been shown that differences in crown morphology, crown efficiency and space occupation 
modify the competitive strength and require a consideration of neighborhood identity because in comparison to the processes that take effect in monocultures, interspecific competition will be stronger or weaker what may result in a misjudgment of competitive interactions. For instance, mixing effects such as complementary crown and growth characteristics or resource use are considered to be able to alleviate the consequences of competition (Kelty, 2006). These effects of interspecific competition need to be understood more precisely in order to develop reliable growth models and to manage mixed forests sustainably (Canham et al., 2006).

In order to quantify individual tree competition, many indices have been designed. Actually they can be classified into two main groups: distance-independent and distance-dependent approaches (Biging and Dobbertin, 1995; Munro, 1974; Porté and Bartelink, 2002). While those belonging to the first group use stand density measures (e.g. basal area) to evaluate the competition pressure of an individual tree, indices of the second category analyze the competitive effect of selected neighbors considering their size, positioning and number (Tomé and Burkhart, 1989). This paper mainly refers to distance-dependent indices, because especially in unmanaged as well as in mixed forests, tree dimensions, species composition or stem number, and, as a consequence, resource availability vary on a small scale (Dale et al., 1985). Consequently, general stand density measures may not adequately describe individual tree competition (Dimov et al., 2008). Nevertheless, competition indices have proven to explain a significant part of individual tree growth variation, even if variables representing initial size oftentimes account for a bigger ratio (Monserud and Sterba 1996). Based on conceptual considerations, it is widely assumed that distance-dependent indices offer more reliable prognoses of single tree growth (Biging and Dobbertin, 1995; Tomé and Burkhart, 1989). However depending on stand structure, management technique and tree species composition the different types of competition measures yielded inconsistent results. Whereas some comparative studies revealed, that additional information on tree locations did not necessarily enhance the accuracy of model estimates (Biging and Dobbertin, 1995; Holmes and Reed, 1991; Lorimer, 1983; Martin and Ek, 1984; Windhager, 1999) other investigations found that the distance-dependent indices accounted for better predictions of diameter growth (Daniels et al. 1986; Elliott and Vose, 1995). This is consistent with Alemdag (1978) or Weigelt and Jolliffe (2003), who suggest that there exists no single universally applicable index. Numerous studies showed that the inclusion of modeled or estimated species-specific crown parameters such as surface and cross-sectional areas resulted in notable improvement of modeling accuracy (e.g. Bachmann, 1998; Biging and Dobbertin, 1992; Oheimb et al., 2011). Crown characteristics provide insights into processes such as uptake and consumption of resources that are essential for the understanding of competitive effects (Dale et al., 1985; Filipescu and Comeau, 2007; Hamilton, 1969). Unfortunately, it is laborious and imprecise to measure crown parameters with conventional methods in the field (Bayer et al., 2013). Consequently such datasets are rarely collected in investigations of intertree competition (Davies and Pommerening, 2008; Oheimb et al., 2011). However, the use of terrestrial laser scanners seem to offer new options for measuring crown size and shape (Henning and Radtke, 2006) which could be used to reform the indices which are based on crown characteristics. Presently most competition measures or stand simulators taking crown interaction in the growing space into account are based on geometric standard crown shapes (e.g. Biging and Wensel, 1990; Canham et al., 2004; Pretzsch et al., 2002; Smith, 1994). Such simplified crown forms do not realistically represent spatial heterogeneity, especially in the canopy of mixed stands. In addition, there is often insufficient data available for modeling individual crown shapes of species others than the main tree species. Thus, the current practice of using standardized integrative crown parameters disregards differences in crown morphology and allometry between and within tree species that are essential for the assessment of individual tree competition or the prediction of tree growth and hence stand development (Frech, 2006). Moreover mechanical damages or adjustments to the local light regime in terms of crown asymmetry (Frech, 2006; Seidel et al., 2011b; Takenaka, 2000) cannot be represented when standard crown shape models are applied.

However, canopy neighborhood plays a key role for the understanding of intertree competition (Thorpe et al., 2010). Thus, the availability of the 'pre-emptable' resource light (Schwinning and Weiner, 1998) is evidentially an important determining factor for the growth of individual trees (Brunner, 1998; King et al., 2005; Lang et al., 2010; Purves et al., 2007; Wyckoff and Clark, 2005) and the amount of photosynthetically active radiation is considered to be a good proxy to characterize competitive stress (Comeau and Heineman, 2003). Moreover the capture of incoming radiation is unequally distributed in the different canopy classes (Dale et al., 1985; Schwinning and Weiner, 1998) due to species specific differences in crown characteristics (Canham et al., 1994). To gain deeper insight into these effects, our study used terrestrial laser scanning (TLS) techniques to quantify neighborhood crown competition and its effect on individual tree growth. Thus, as implemented in other studies, competition by neighboring trees is not assumed to be comparable for different species (Canham et al., 2004; Perot et al., 2010; Pretzsch and Schütze, 2005). In contrast, competition for light by neighbors depends on species, canopy density and on the dimensions and shapes of its crowns (Pacala et al., 1996). Our hypotheses were (i) that information derived from TLS-based high-resolution tree structural characteristics outmatches existing competition indices and crown shape models, hence increases the accuracy of quantifying neighborhood competition, and (ii) that improved crown modeling and competition index structure enhances the correlations with target tree growth under intra- and interspecific competitive situations. To our knowledge only few attempts have been made to apply terrestrial LiDAR for the determination neighborhood competition. The only studies we are aware of suggest that realistic images of individual crown architecture generate additional information on neighborhood competition in the canopy of boreal forests and improve the prediction accuracy of diameter growth models (Ducey et al., 2011; Seifert, 2012). However, we do not know of any study where terrestrial laser scanning was used to systematically explore the effect of intra- and interspecific competition on tree growth.

\section{Methods}

\subsection{Study area}

We examined tree groups growing on the forest field plots of the German Biodiversity Exploratories. These study plots are situated in three different major geographic regions of Germany. The Biosphere Reserves Schorfheide-Chorin (SCH) in the State of Brandenburg, Swabian Alb (ALB) in the State of Baden-Württemberg as well as the Thuringian Hainich-Dün region (HAI) including the UNESCO World Heritage National Park were selected as investigation areas. Further information on the experimental setup and a detailed geographical classification of the Exploratories can be found in Fischer et al. (2010). At all sites beech grows in monocultures and in mixed stands. Due to site conditions and forest history, admixed tree species differ between the three Exploratories. Pinus sylvestris is most frequent in the Schorfheide-Chorin area, valuable hardwoods such as Acer pseudoplatanus, Fraxinus excelsior, Quercus 
Table 1

General information on the study sites located in Northeast-, Central- and Southwest Germany (information on soil properties from Solly et al., 2013).

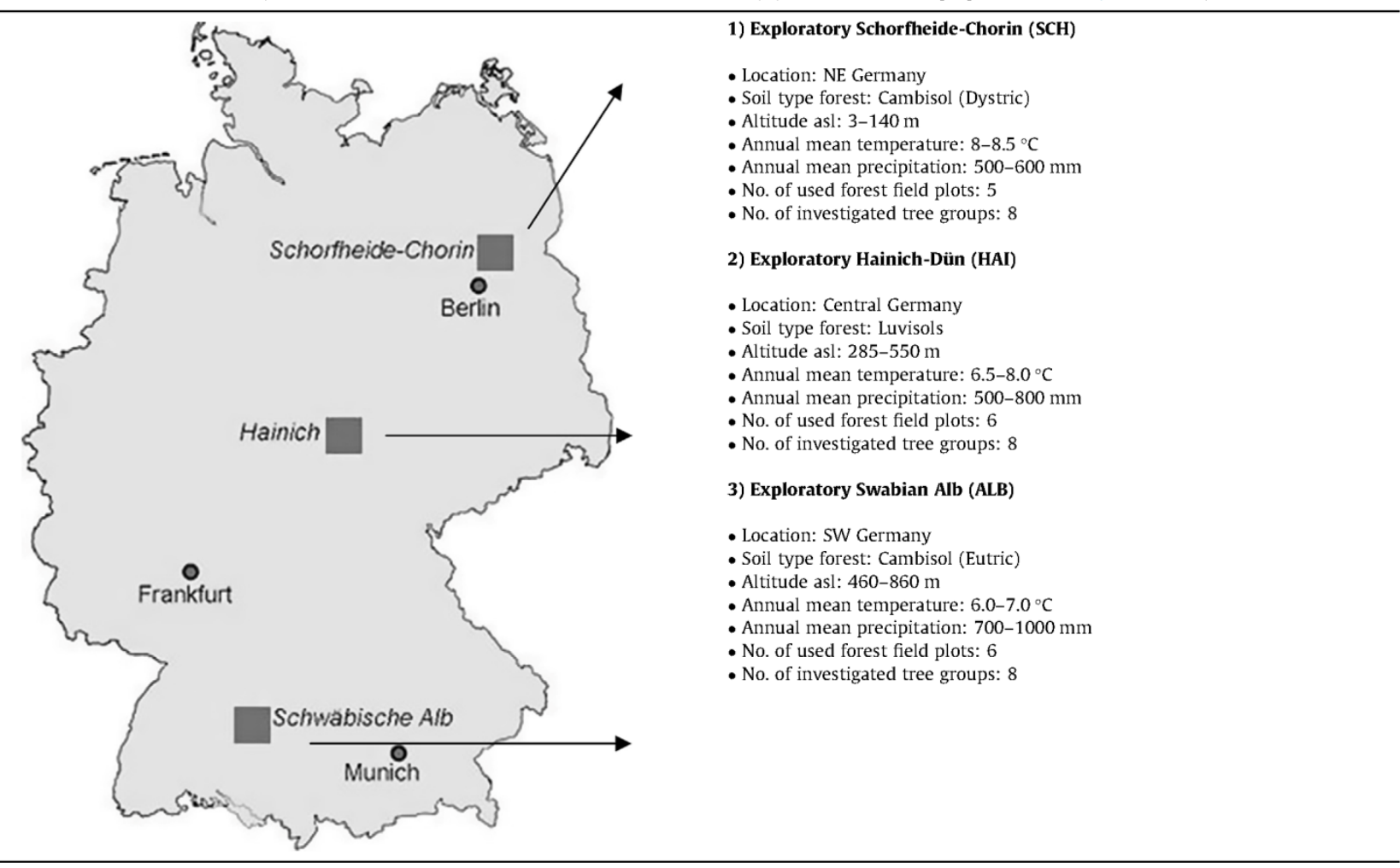

spec. or Tilia cordata form mixed stands with beech in the HainichDün region, and Picea abies-Fagus sylvatica mixtures dominate on the Swabian Alb sites. Thus, at all three sites we compared the competitive effect of different tree species on growth of European beech (see Fig. 1). Adjacent to intraspecific interference in pure stands of $F$. sylvatica (inclusion of four groups per exploratory), interspecific competition in local forest communities was investigated by analyzing canopy neighborhood and growth of four additional beech target trees in every region being surrounded by the other site adapted species typical for the particular growing area (Table 2).

In each of the three regions 5-6 out of 50 experimental plots were selected for the measurements (Table 1). On the selected plots, a total of 24 tree groups each consisting of 5 trees (one target tree and four competitors) were chosen before foliation (see Fig. 1). The criteria for the selection of the tree groups were:

(i) if possible, dbh of the target beech trees $>30 \mathrm{~cm}$,

(ii) target beech trees should belong to the overstorey,

(iii) tree groups should show no evidence of harvesting operations in the recent past,

(iv) target trees should be surrounded by four preferably symmetrically arranged neighbors.

\subsection{Terrestrial laser scanning}

Each group of trees was scanned using the terrestrial threedimensional laser scanner Zoller and Froehlich Imager 5006 (Zoller und Froehlich $\mathrm{GmbH}$, Wangen, Germany) from at least six different positions (mean:10; max:12) in March 2012. The number of different positions depended on (i) the overall visibility at the study site as determined by the density of the understory vegetation, (ii) the extent of the tree group to be scanned and (iii) the tree species composition. We used a modified 'corners setup' as presented in van der Zande et al. (2008) with a central scan and a sequence of surrounding scans. Coniferous trees usually required more scan perspectives than tree groups consisting of deciduous species due to the limited visibility through a coniferous tree crown even in winter time. The Imager 5006 was mounted on a tripod at a mean height of $1.4 \mathrm{~m}$ above ground and was operated in 'High' mode, resulting in a $360^{\circ}$ horizontal and $310^{\circ}$ vertical field of view scanned with 86 million measurements in about $3.5 \mathrm{~min}$. In an angular step of $0.036^{\circ}$ in both, horizontal and vertical direction, the instrument thereby actively emits a red laser beam (wavelength: $650-690 \mathrm{~nm}$ ) and detects the signal reflected by objects in field of view. The three dimensional polar coordinates of each reflected laser measurement were stored on the instruments hard disk with $\mathrm{mm}$-accuracy including the intensity of the signal reflected. In order to create a three-dimensional model of the scanned tree-group from the data obtained at the different perspectives, 24 artificial fix-points (laminated 'chessboard'-paper attached to tree stems) were distributed within the forest patch to be used for the co-registration of the coordinates created in each scan using ZF-Laser Control 8.2 software (Zoller und Froehlich GmbH, Wangen, Germany). Scans were than filtered as described in Seide et al. (2011a) and exported as zfs-files with the newly registered coordinate system common to all scans of a tree group.

\subsection{Data processing}

All zfs-files were imported to Cyclone 6 (Leica Geosystems $\mathrm{GmbH}$, Munich, Germany) and each tree group was visualized as 
Table 2

Main characteristics of target trees and their neighbors in the three Biodiversity Exploratories.

\begin{tabular}{|c|c|c|c|c|c|c|c|c|c|c|c|c|c|c|c|c|c|c|}
\hline \multirow{2}{*}{$\begin{array}{l}\text { Target } \\
\text { tree }^{*}\end{array}$} & \multirow[t]{2}{*}{ Exploratory } & \multirow{2}{*}{$\begin{array}{l}\text { Height } \\
(\mathrm{m})\end{array}$} & \multirow{2}{*}{$\begin{array}{l}\mathrm{DBH} \\
(\mathrm{cm})\end{array}$} & \multirow{2}{*}{$\begin{array}{l}\text { No. of } \\
\text { neighbors }\end{array}$} & \multicolumn{8}{|c|}{ Species of the neighbors* } & \multicolumn{6}{|c|}{ Neighbors structural parameters } \\
\hline & & & & & $\mathrm{Be}$ & Pin & Pic & Ac & $\mathrm{Fr}$ & Qu & $\mathrm{Ti}$ & $\mathrm{Ca}$ & $\begin{array}{l}\text { Mean } \\
\text { height } \\
(\mathrm{m})\end{array}$ & $\pm \mathrm{SD}$ & $\begin{array}{l}\text { Mean } \\
\text { DBH }(\mathrm{cm})\end{array}$ & $\pm \mathrm{SD}$ & $\begin{array}{l}\text { Mean crown } \\
\text { volume }\left(\mathrm{m}^{3}\right)\end{array}$ & $\pm S \mathrm{D}$ \\
\hline Be 1 & HAI & 32.03 & 41.60 & 4 & 0 & 0 & 0 & 0 & 4 & 0 & 0 & 0 & 30.71 & 0.88 & 41.20 & 4.67 & 159.86 & 109.73 \\
\hline Be 2 & HAI & 31.24 & 45.50 & 4 & 4 & 0 & 0 & 0 & 0 & 0 & 0 & 0 & 31.20 & 1.05 & 59.80 & 11.33 & 613.36 & 226.06 \\
\hline Be 3 & HAI & 34.44 & 50.40 & 4 & 4 & 0 & 0 & 0 & 0 & 0 & 0 & 0 & 32.51 & 1.88 & 44.78 & 12.48 & 262.16 & 154.01 \\
\hline Be 4 & $\mathrm{HAI}$ & 31.63 & 41.60 & 4 & 4 & 0 & 0 & 0 & 0 & 0 & 0 & 0 & 32.44 & 0.54 & 64.05 & 9.66 & 578.51 & 314.45 \\
\hline Be 5 & HAI & 31.88 & 42.70 & 4 & 4 & 0 & 0 & 0 & 0 & 0 & 0 & 0 & 30.39 & 0.53 & 48.15 & 9.05 & 275.29 & 82.39 \\
\hline Be 6 & $\mathrm{HAI}$ & 22.72 & 31.30 & 4 & 0 & 0 & 0 & 2 & 2 & 0 & 0 & 0 & 25.67 & 1.78 & 36.40 & 9.24 & 194.44 & 143.29 \\
\hline Be 7 & HAI & 29.30 & 51.50 & 4 & 0 & 0 & 0 & 1 & 0 & 1 & 1 & 1 & 29.19 & 1.48 & 63.10 & 12.80 & 541.55 & 265.93 \\
\hline Be 8 & HAI & 23.72 & 30.30 & 4 & 0 & 0 & 0 & 4 & 0 & 0 & 0 & 0 & 24.48 & 1.43 & 46.39 & 16.72 & 406.49 & 362.46 \\
\hline Be 9 & $\mathrm{SCH}$ & 27.92 & 37.20 & 4 & 0 & 4 & 0 & 0 & 0 & 0 & 0 & 0 & 27.86 & 0.80 & 40.62 & 9.16 & 74.12 & 51.35 \\
\hline Be 10 & $\mathrm{SCH}$ & 23.25 & 26.20 & 4 & 0 & 4 & 0 & 0 & 0 & 0 & 0 & 0 & 26.59 & 1.27 & 41.32 & 7.19 & 73.94 & 21.39 \\
\hline Be 11 & $\mathrm{SCH}$ & 25.18 & 42.30 & 4 & 0 & 4 & 0 & 0 & 0 & 0 & 0 & 0 & 26.99 & 1.00 & 38.20 & 6.17 & 50.26 & 25.97 \\
\hline Be 12 & $\mathrm{SCH}$ & 36.01 & 40.00 & 4 & 4 & 0 & 0 & 0 & 0 & 0 & 0 & 0 & 36.56 & 0.96 & 46.65 & 8.15 & 200.97 & 186.56 \\
\hline Be 13 & $\mathrm{SCH}$ & 34.11 & 50.10 & 4 & 4 & 0 & 0 & 0 & 0 & 0 & 0 & 0 & 34.98 & 0.83 & 75.87 & 3.64 & 1160.51 & 237.94 \\
\hline Be 14 & $\mathrm{SCH}$ & 24.33 & 37.30 & 4 & 0 & 4 & 0 & 0 & 0 & 0 & 0 & 0 & 27.21 & 1.29 & 42.90 & 5.27 & 92.79 & 72.51 \\
\hline Be 15 & $\mathrm{SCH}$ & 26.47 & 43.30 & 4 & 4 & 0 & 0 & 0 & 0 & 0 & 0 & 0 & 25.75 & 1.33 & 38.50 & 10.97 & 219.49 & 121.45 \\
\hline Be 16 & $\mathrm{SCH}$ & 26.09 & 37.00 & 4 & 4 & 0 & 0 & 0 & 0 & 0 & 0 & 0 & 25.35 & 0.54 & 37.82 & 3.74 & 250.08 & 88.35 \\
\hline Be 17 & ALB & 27.21 & 30.00 & 4 & 4 & 0 & 0 & 0 & 0 & 0 & 0 & 0 & 27.14 & 1.32 & 34.22 & 1.31 & 189.79 & 41.54 \\
\hline Be 18 & ALB & 32.51 & 34.70 & 4 & 4 & 0 & 0 & 0 & 0 & 0 & 0 & 0 & 32.70 & 0.78 & 39.42 & 1.33 & 304.39 & 55.31 \\
\hline Be 19 & ALB & 30.29 & 42.00 & 4 & 4 & 0 & 0 & 0 & 0 & 0 & 0 & 0 & 30.41 & 1.21 & 40.05 & 4.59 & 277.43 & 137.56 \\
\hline Be 20 & ALB & 23.67 & 22.10 & 4 & 0 & 0 & 4 & 0 & 0 & 0 & 0 & 0 & 25.80 & 0.95 & 36.40 & 3.60 & 89.37 & 18.35 \\
\hline Be 21 & ALB & 22.43 & 37.70 & 4 & 0 & 0 & 4 & 0 & 0 & 0 & 0 & 0 & 21.13 & 1.92 & 27.97 & 4.55 & 65.91 & 18.01 \\
\hline Be 22 & ALB & 24.55 & 35.20 & 4 & 0 & 0 & 4 & 0 & 0 & 0 & 0 & 0 & 27.35 & 0.67 & 42.00 & 2.62 & 225.92 & 55.53 \\
\hline Be 23 & ALB & 26.49 & 34.70 & 4 & 4 & 0 & 0 & 0 & 0 & 0 & 0 & 0 & 26.54 & 0.65 & 33.20 & 5.02 & 264.80 & 149.31 \\
\hline Be 24 & ALB & 24.00 & 27.30 & 4 & 0 & 0 & 4 & 0 & 0 & 0 & 0 & 0 & 24.44 & 3.38 & 34.60 & 8.05 & 111.38 & 66.57 \\
\hline
\end{tabular}

$\mathrm{Be}=$ Fagus sylvatica; Pin = Pinus sylvestris; $\mathrm{Pic}=$ Picea abies; $\mathrm{Ac}=$ Acer pseudoplatanus; $\mathrm{Fr}=$ Fraxinus excelsior; $\mathrm{Qu}=\mathrm{Quercus}$ spec ; $\mathrm{Ti}=\mathrm{Tilia}$ cordata; $\mathrm{Ca}=\mathrm{Carpinus}$ betulus

a unified point cloud based on the registration made previously. In a next step all trees of the group including the target tree (24 groups $\times 5$ trees; in total 120 trees) were extracted by hand as we did not know of any algorithm that identifies trees in the point cloud with a higher precision than the human eye. By changing the perspective from which the point cloud is examined during the selection process in Cyclone, tree extraction has shown to be sufficiently precise especially when using trees scanned in the leafless state (e.g. Seidel et al., 2011b). However, this kind of single tree extraction is a subjective procedure. Therefore, based on a random subsample of 30 out of the 120 trees, we also compared tree-specific attributes resulting from point clouds extracted independently by two different operators.

The point clouds of all 120 trees were exported as xyz-files. These files were finally used to detect and quantify competition between trees (see below) using algorithms written in Mathematica 8 (Wolfram Research Inc., Champaign, USA).

\subsection{Competitor selection and quantification of competition}

For the selection of competitors Pretzsch (1995) suggested an innovative approach. It is based on the so-called search cone method which integrates competitor identification and the quantification of competition in one step (Bachmann, 1998). Thus a search cone with a fixed opening angle is spanned from a defined position of the target tree for the purpose of competitor selection (Biging and Dobbertin, 1992; Pretzsch, 1995; Pretzsch et al., 2002). Surrounding trees whose crown tips intersect the surface line of the search cone are classified as competitors. However, for both, target tree and neighboring trees standard crown shapes are used (see Fig. 2).

From the terrestrial laser scans individual crown shapes were created. In order to define the crown dimensions for each of the 120 trees, a series of structural attributes was automatically extracted from the point clouds (see Seidel et al., 2011b). Based on
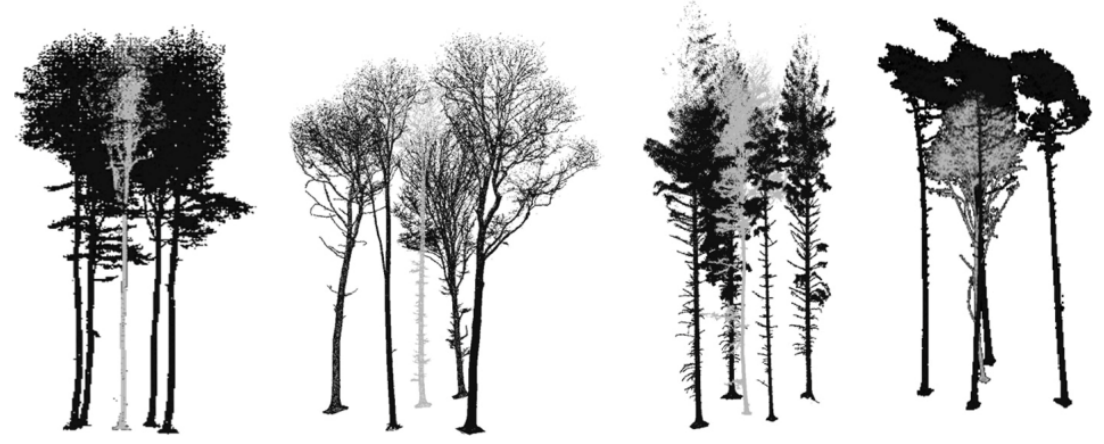

Fig. 1. Sample 2D-representations of 3D-point clouds of the investigated competitive situations. From left to right: beech vs. beech; beech vs. valuable hardwood; beech vs. spruce; beech vs. pine. 
the xyz-files containing the extracted point cloud of each tree, we first determined the total tree height (TTH) by subtracting the zvalue of the lowest point in the point cloud from the z-value of the highest point (e.g. Hopkinson et al., 2004). In order to homogenize the data density which would naturally decrease to the top of the trees due to the angular measurement scheme of the scanner when operated from the ground, we used a $10 \mathrm{~cm}$ voxel model of all point clouds. For every voxel model of a tree, the area of each polygon being defined by all voxels within a slice of $10 \mathrm{~cm}$ thickness was computed. Thereby, the tree is virtually sliced from the bottom to the top and each slice contains a number of voxels located in a single height layer as voxels edge length equals slice thickness. Polygon areas described by the voxels were combined with the height value they were found in and thereby the height of maximum crown extension (Hmaxarea) could be calculated (Seidel et al., 2011b). Starting at this height we performed a downward directed search for crown base height, defined as the height of that polygon that first fell under twice the basal area of the tree. This approach avoids epicormic branches wrongly detected as crown base height. Competitor selection used two differing approaches. First each scanned tree of which at least one voxel was arranged within the search-cone of, $60^{\circ}$ opening angle positioned at $60 \%$ of the target trees height (Pretzsch, 1995), was classified as a competitor (see Figs. 2 and 3 for illustration). We decided to fix the upside down tip of the search cone exactly vertically above the stem base point of each tree in order to follow the methodology proposed by Pretzsch (2002). The developed algorithm treated the target tree in a pair-wise manner with each neighbor tree separately. Alternatively, all 4 neighbors (which had been classified as competitors by a forester because they had crown contact with the target tree) were considered as competitors for the further calculations. In the following, all voxels of a tree crown were selected and the convex hull of the crown's point cloud was calculated. The surface of this hull (Fig. 3) was than derived using Heron's formula for the triangles building the outer hull and was considered to be the crown surface area.

For quantifying the competition effect of the neighbors on a target tree, Pretzsch (1995) introduced the so-called KKL index which

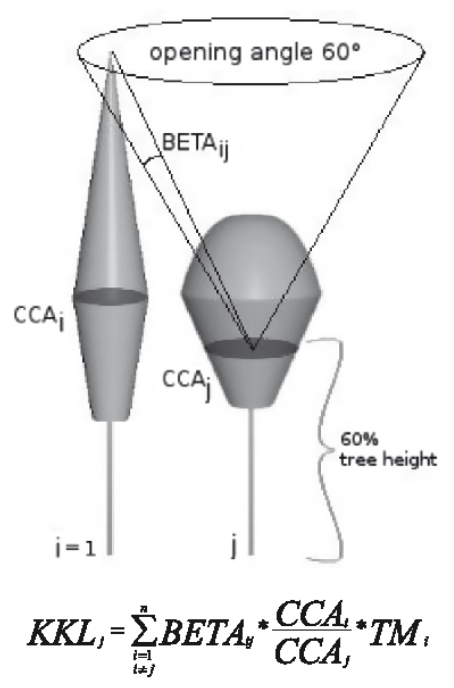

Fig. 2. Calculation of the competition index KKL based on crown shape models (Pretzsch et al., 2002).

ascertains the social status of the focal tree compared to his competitors (Pretzsch, 2001). It is calculated in consideration of tree height- and crown size relations by adding the angles (in radians) between the cone shell of the focal tree and the connecting lines from the apex to the tree top of all competitors. This angular sum is weighted with the ratios of the crown cross-sectional areas from the target tree and its competitors in a fixed height (Fig. 2). Because not only distances, height ratios and crown size proportions control the competitive strength of neighboring trees but also light transmission of the crowns a species-specific coefficient of transmission is part of the index (Pretzsch, 2001).

In the case of the "real" crown shapes crown competition the focal tree is exposed to was evaluated by stepwise calculation of 'Competitors' Crown Surface Area' of the trees selected by the step 1: competitor identification
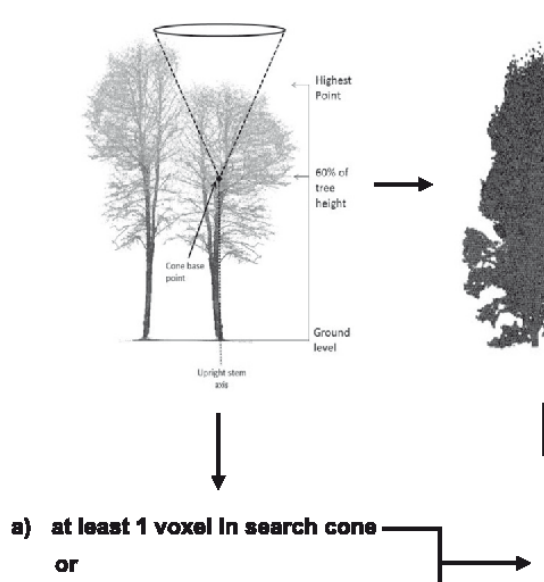

or

b) crown contact

c) neither any voxel in search cone

nor

d) crown contact

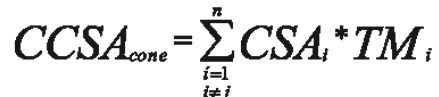

step 2: quantification of crown competition
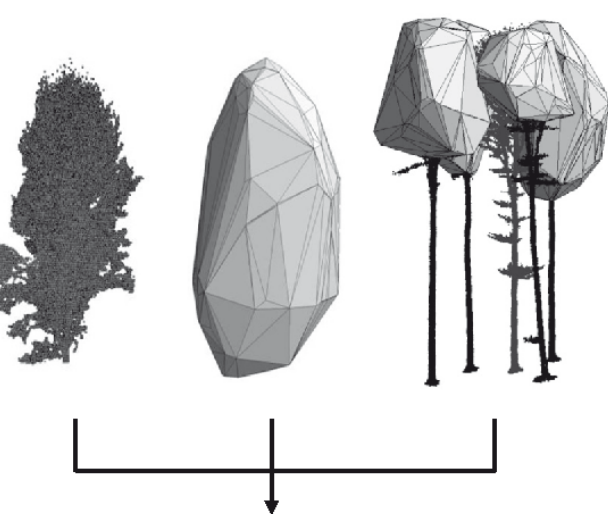

$\underset{\substack{i=1 \\ i \neq j}}{ }$

tree is not considered as a competitor

Fig. 3. An example of application of the search cone to detect competitors and the formula to measure the competitive strength enforced on a target tree based on TLS-data. 
search cone ( $\mathrm{CCSA}_{\mathrm{Cone}}$ in $\mathrm{m}^{2}$ ) or all four neighboring trees (CCSA in $\mathrm{m}^{2}$ ). Species identity and hence differences in light transmission were considered as in Pretzsch (2001) by coefficients of transmission [TM]. These weigh the competitive effect of neighbors as follows: F. sylvatica: 1.0 ; P. abies: 0.8 ; Quercus petraea: 0.5 and $P$. sylvestris: 0.2 . Because of the nonavailability of typal parameter estimations for some of the valuable hardwood tree species, they were treated as for beech in all calculations. We tested a variety of parameters derived from the TLS-data that describe competition by the competitor trees (see Appendix F) and hypothesized that the summed and weighed crown surface areas of the neighbor trees provided the best results.

\subsection{Measuring individual tree growth}

Before the beginning of the 2012 growing season, all target trees were equipped with electronic self-acting DC2 circumference dendrometers (www.ecomatik.de) at breast height that generate measurement readings half hourly. Once a day, measurements were automatically transmitted from the Scatter 100 sensor units to Scatter 100 base stations which send them to an online database by GSM and additionally write them on an integrated SD card for data backup. For the purpose of calculating the increment of the selected trees, individual calibration tables were inserted into the evaluation software LOGSTAR. By recursive computation this communication module converts the percentage value that is measured from the potentiometer to the actual circumference in $\mathrm{mm}$ and to growth in $\mu \mathrm{m}$. The comparisons of growth rates itemized below refer to the basal area increment on the reference date 31st October 2012 compared to the initial basal area at the day when the dendrometer was installed.

\subsection{Statistical analysis}

All statistical computations were carried out with the free software environment ' $R$ ', version 2.12.2 ( $R$ Development Core Team, 2012). The kappa coefficient which is used for the comparative evaluation of the competitor identification based on the real and modeled crown shapes was calculated using Microsoft Excel. This statistical measure provides one means of the assessment of the interrater variation relating to categorical variables and is accounted to be more reliable than percentage accordance because it considers a certain proportion of chance agreement (Cohen, 1960; Grouven et al., 2007). Because of the small sample sizes (12 independent observations in pure beech stands and 4 in each group of interspecific competition), it did not make sense to check for normal distribution of the data or for variance homogeneity in all groups. Therefore a non-parametric Kruskal-Wallis ANOVA was performed to test for differences in the magnitude of competition on the target beech trees by the four competitor tree species (beech, valuable hardwood, spruce and pine) expressed by the competition indices. The same statistical method was employed to test the effect of the four different competitor tree species on basal area growth. For the post hoc-analysis we used Wilcoxon's rank sum test with Bonferroni correction because of the small number of replicates. As an alternative procedure we employed the package 'nparcomp' which provides a nonparametric method for multiple comparisons based on relative contrast effects that is robust against violations of the assumptions parametric tests rely on. Significance level was $p<0.05$ in all tests. Target tree basal area growth was analyzed using linear mixed effects models (package: nlme) that, as full model, included competition indices, initial dbh and their interaction as fixed effects as well as site (Biodiversity Exploratory) as random effect. As candidate models we used the full model and all simplifications of it. The best approximating models were selected using an information-theoretic approach
(Burnham and Anderson, 2002) based on Akaike's Information Criterion adjusted for small samples (AICc; package: AICcmodavg).

\section{Results}

\subsection{Examination of the manual extraction method}

A comparison of the tree structural parameters obtained from point-clouds that were manually extracted by two different operators reveals a large degree of objectivity (Fig. 4). The coefficient of correlation between the values ranged from 0.92 to 1.0 (Fig. 4). In particular, those attributes that are generally imposed in forest inventories and often used for the calculation of competition indices like $\mathrm{dbh}$, total tree height or crown cross-sectional area ( $\triangleq$ MaxArea) show high self-consistency (Fig. 4; Appendix A). With an error probability of $5 \%$, intercepts and slope were found to be not different from 0 respectively 1 .

\subsection{Modeled vs. TLS-derived crowns: competitor selection with the search cone method}

The competitor identification method suggested by Pretzsch (1995) is based on a search cone with an opening angle of $60^{\circ}$ that is attached at $60 \%$ of the target trees' height. When applied to the crown morphologies derived from TLS-data it yielded different results than for the species-specific standard crown shape models. Each of the 24 central trees has four neighbors that were recorded as potential competitors as their crowns interfered. From these 96 trees, 64 were identified as competitors by both approaches. Twelve trees were not considered as competitors regardless if the real or modeled crown structures were implemented (Table 3 ). Thus, when disregarding the competitor tree species, in $79 \%$ of all observations both approaches came to the same conclusion. Interestingly, in $85 \%$ of the remaining 20 comparisons, the neighboring trees were likewise classified as competitors by the TLS-approach, which is one reason for the comparatively low kappa coefficient of 0.43 . No change of the overall pattern of agreement/disagreement between TLS- and standard crown models was found when tree species of the competitors were taken into account. For Norway spruce ( $P$. abies) the agreement between the two approaches seems to be even higher (Table 3 ).

\subsection{Modeled vs. TLS-derived crowns: quantification of competition}

The KKL, Pretzsch's (1995) competition index, ascribed the highest competitive strength to the intraspecific competition. In contrast to the valuable hardwoods which caused slightly lower crown competition, both conifers showed a weak competitive effect (Fig. 5). Wilcoxon's rank sum test indicated significant differences between the mean KKL-values of the competitor tree species beech and spruce respectively pine. In contrast the test with the 'nparcomp'-package additionally revealed significant differences between valuable hardwood and spruce as well as pine (Appendix D.1 and D.2).

As KKL, CCSA indicated the same ranking of competitive impact by neighboring species (Fig. 5), irrespective if all four neighbors were taken into account or if only those trees were considered for calculating CCSA which had been selected by the search cone

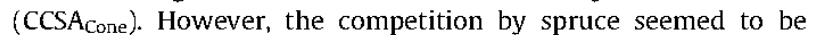
rated higher by CCSA than by KKL. As for the latter, with the rank sum test statistically significant differences between the competitive strengths of the neighboring species were only found for European beech, Norway spruce, and Scots pine $(p<0.05)$. Again, the nonparametric all-pairs comparisons yielded further statistical significance between the competition effect of the tree species pine 

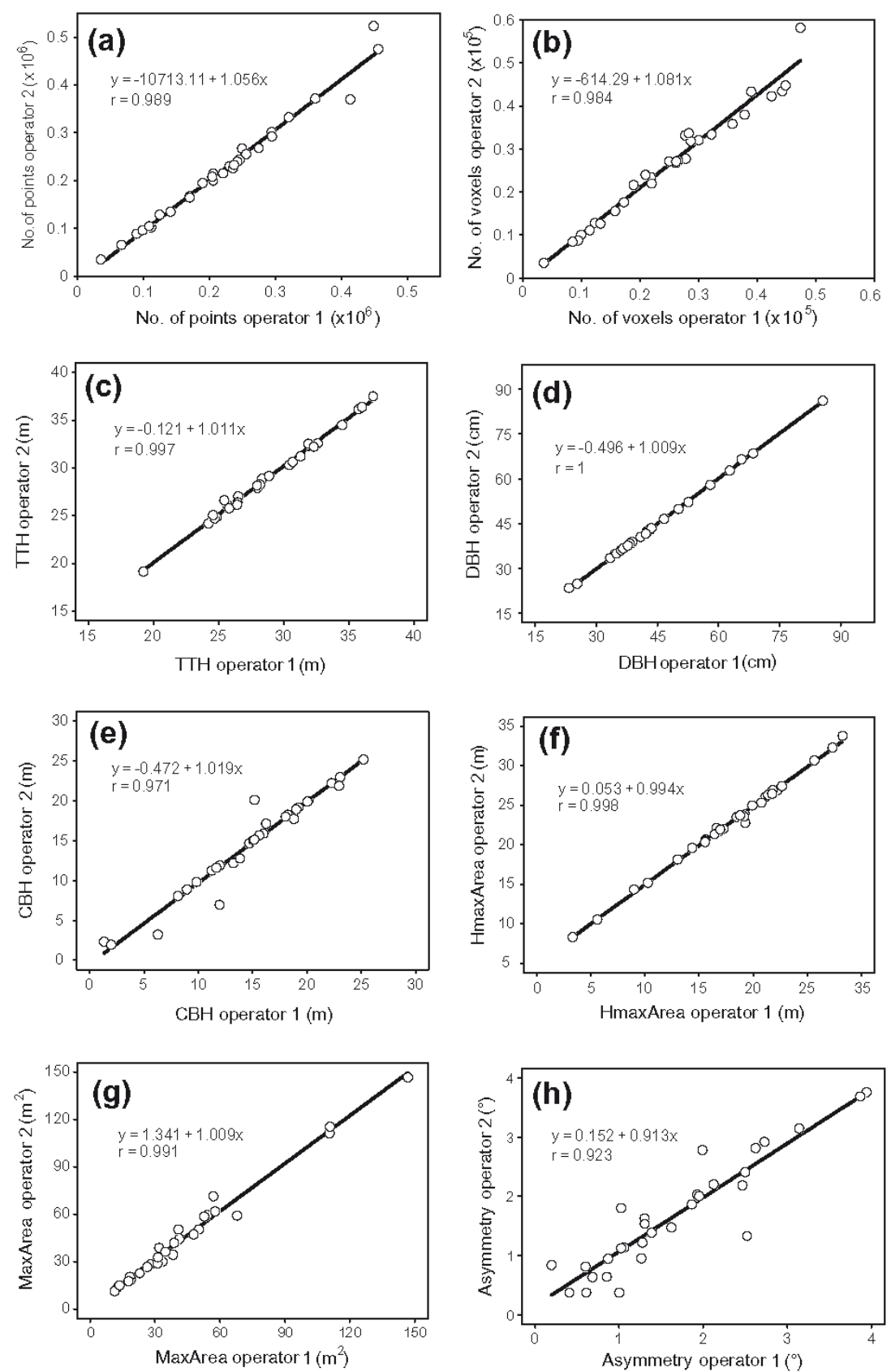

Fig. 4. Relationship between crown structural parameters calculated with the same algorithm but based on two different point clouds created by two different operators.

and valuable hardwood as well as spruce (Appendix D.1 and D.2). The box-whisker-plots (Fig. 5) reveal that within the groups of competitor tree species, the dispersion of the measured values is higher in case of the broad-leaved tree species what does apply in the same manner for the KKL as well as for both versions of the CCSA.

Pearson's $r$ amounted to $0.53(p=0.008)$ and accordingly 0.52 $(p=0.009)$, revealing a significant positive correlation between the KKL and CCSA (Fig. 6). Spearman's rank correlation rho reached slightly higher values of $0.65(p=0.001)$ and $0.63(p=0.001)$ The results of the correlation analysis and the fact, that the plotted 95\% confidence interval included both correlation lines implies that the linear relationship between KKL and CCSA is nearly the same, regardless if the competitors for the calculation of the TLSbased index were selected with the search cone or on condition that they had crown contact with the target tree.

\subsection{Individual tree competition and basal area growth}

The relative basal area increment of the target trees in 2012 behaved strictly opposite compared to the competitive stress indicated by KKL and CCSA. However, according to both test procedures used for the multiple comparisons, the differences in growth were significant only for beech trees surrounded by other 
Table 3

Results of competitor selection with the search-cone in case of modeled and real crowns.

\begin{tabular}{|c|c|c|c|c|c|}
\hline & \multicolumn{4}{|c|}{ Competitor identification with crown shape model } & \multirow[t]{2}{*}{ Kappa coefficient } \\
\hline \multicolumn{5}{|l|}{ Beech vs. all competitor species } & \\
\hline \multirow[t]{4}{*}{ Competitor identification with scanner data } & & Yes & No & $\Sigma$ & \multirow{4}{*}{0.43} \\
\hline & Yes & 64 & 17 & 81 & \\
\hline & No & 3 & 12 & 15 & \\
\hline & $\Sigma$ & 67 & 29 & 96 & \\
\hline \multicolumn{6}{|l|}{ Beech vs. beech } \\
\hline \multirow[t]{4}{*}{ Competitor identification with scanner data } & & Yes & No & $\Sigma$ & \multirow{4}{*}{0.35} \\
\hline & Yes & 34 & 9 & 43 & \\
\hline & No & 1 & 4 & 5 & \\
\hline & $\Sigma$ & 35 & 13 & 48 & \\
\hline \multicolumn{6}{|l|}{ Beech vs. valuable hardwood } \\
\hline \multirow[t]{4}{*}{ Competitor identification with scanner data } & & Yes & No & $\Sigma$ & \multirow{4}{*}{0.38} \\
\hline & Yes & 8 & 5 & 13 & \\
\hline & No & 0 & 3 & 3 & \\
\hline & $\Sigma$ & 8 & 8 & 16 & \\
\hline \multicolumn{6}{|l|}{ Beech vs. pinus } \\
\hline \multirow[t]{4}{*}{ Competitor identification with scanner data } & & Yes & No & $\Sigma$ & \multirow{4}{*}{0.43} \\
\hline & Yes & 9 & 3 & 12 & \\
\hline & No & 1 & 3 & 4 & \\
\hline & $\Sigma$ & 10 & 6 & 16 & \\
\hline \multicolumn{6}{|l|}{ Beech vs. picea } \\
\hline \multirow[t]{4}{*}{ Competitor identification with scanner data } & & Yes & No & $\Sigma$ & \multirow{4}{*}{0.76} \\
\hline & Yes & 13 & 0 & 13 & \\
\hline & No & 1 & 2 & 3 & \\
\hline & $\Sigma$ & 14 & 2 & 16 & \\
\hline
\end{tabular}

beech or by pine trees (Appendix D.1 and D.2). Beeches exclusively surrounded by Scots pines showed the highest mean relative increment in relation to their initial basal area, whereas the average growth of their conspecifics which were growing in pure stands was not even half as high (Fig. 7 left). With regard to absolute basal area increment beech in the neighborhood of spruces exhibit the lowest productivity (Appendix C, Fig. 7 right). This result is most likely caused by the low mean initial $\mathrm{dbh}(30.56 \mathrm{~cm})$ of the beech trees surrounded by spruce which was smaller than the corresponding values of the target trees in pure stands $(41.00 \mathrm{~cm})$ or in mixture with noble hardwoods $(38.68 \mathrm{~cm})$ and pine $(35.75 \mathrm{~cm})$. Significant negative correlations between absolute target tree basal area increment and competition were only found for the TLS-based indices, indicating a decreasing annual increment with increasing competitive stress (Appendix C). Compared to the crown-shape-model based KKL, the coefficient of correlation between growth and competition was substantially higher in the case of both versions of CCSA (Appendix C). An internal comparison based on the AICc (Appendix E) and Pseudo $R^{2}$-values showed that the advisory competitor selection (CCSA) again performed slightly better than the adoption of the search-cone approach to the real crown shapes $\left(\mathrm{CCSA}_{\text {Cone }}\right)$. The same applies to the analysis of the functional relationship between basal area growth and the compe-

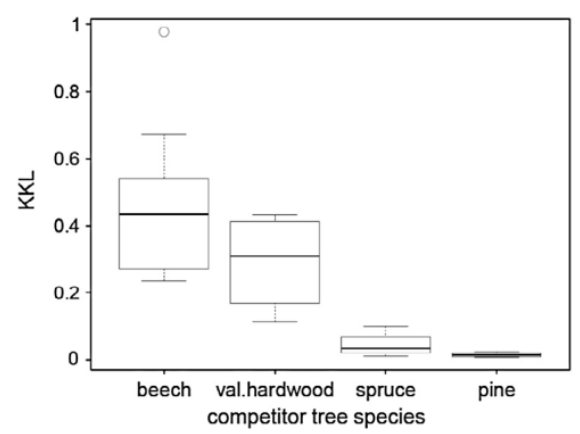

Fig. 5. Boxplots of both competition indices separately for the different competitor tree species.

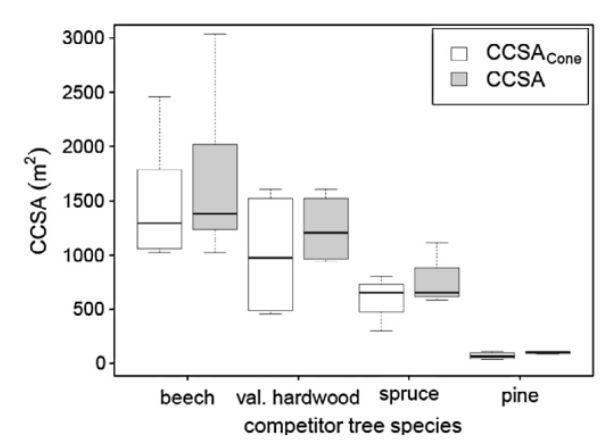

Fig. 6. Relationship between the competition indices KKL and CCSA respectively CCSA $_{\text {cone }}$ for the 24 target tree beeches under intra- and interspecific competition.

tition indices with linear mixed effects models that include initial size and the effect of the different sites (Biodiversity Exploratories) (Table 4; Fig. 8). Models containing the CCSA, which is calculated on the basis of scanned crown shapes, are consistently superior 

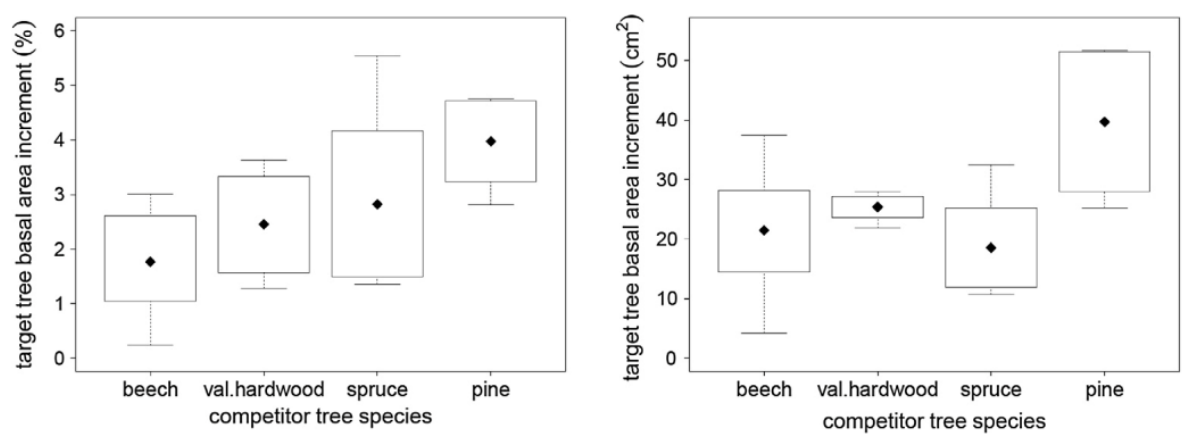

Fig. 7. Mean basal area increment of the target tree beeches in relative (\% of initial basal area, left) or absolute ( $\mathrm{cm}^{2}$, right) terms under intra- and interspecific competition.

to those that incorporate the model-based KKL (Table 4; Appendix E). As is evident from the right part of Fig. 8, the bigger the initial size of the target tree, the less severe is the effect of competition on basal area growth. Waiving on the TM in the calculation of the TLSbased competition indices results in a slight decrease of the correlation coefficients between target tree basal area growth and CCSA $(r=-0.47 ; p=0.02)$ as well as $\mathrm{CCSA}_{\text {Cone }}(r=-0.46 ; p=0.02)$.

\section{Discussion and conclusions}

\subsection{Methodical considerations}

Based on a pilot-study we see that the single tree extraction from point clouds by hand is to a large degree objective and that such data can be used to calculate various tree characteristics. The fact that crown asymmetry is the parameter that features the lowest agreement between operators results from error propagation as it is calculated based on other parameters, such as max-

Table 4

Evaluation of linear mixed effects model fits using the information-theoretic AICcapproach.

\begin{tabular}{llll}
\hline \multicolumn{4}{l}{ lme $(\Delta$ Basal area $\sim$ model, random $=\sim 1$ (exploratory) } \\
\hline Model & AlCc & AlCc weight & Pseudo $R^{2}$ \\
\hline CCSA $^{*}+$ dbh & 189.73 & 0.39 & 0.34 \\
CCSA & 189.82 & 0.38 & 0.24 \\
CCSA + dbh + CCSA: dbh & 192.36 & 0.11 & 0.36 \\
Only intercept & 193.50 & 0.06 & 0 \\
KKL & 193.84 & 0.05 & 0.10 \\
KKL + dbh & 197.00 & 0.01 & 0.10 \\
KKL + dbh + KKL: dbh & 199.81 & 0.00 & 0.13 \\
\hline
\end{tabular}

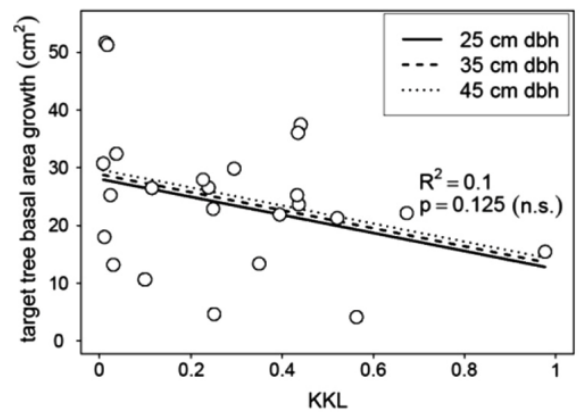

Signif. code: $\leqslant 0.05$.

imum crown extension. Nevertheless, the measurement deviations for several tree-crown attributes that result from the comparator check based on point clouds extracted independently by two different operators (Appendix A) confirm the finding of Fleck et al. (2011) that a repeated employment of conventional, hand operated and sight-based measuring devices for the determination of treeand especially crown parameters can hardly produce results comparable to TLS.

In case of the utilized indices, crown shape and dimension play a major role for the selection of potential competitors and for calculating their competitive strength. In fact using crown shapes derived from TLS-techniques led to more competitors and to a higher precision in estimating tree growth response to competition than using standard crown shape models (Fig. 8; Appendix C).

The observed differences in the number of identified competitors when applying the search cone approach to simple geometric or "real" crown shapes may have manifold reasons. First, the search cone is put in place perpendicular to the root collar of the target tree. Consequently, for the modeled trees, it is located in extension of their crown centre because all trees are expected to grow uniformly upright (Pretzsch et al., 2002). In real stands the stems of nearly all trees are inclined to a certain degree. This was most obvious for pine-trees. Therefore even competitors growing in a greater distance to the target tree can reach into the inverted cone. Second, real crowns are far away from being rotation-symmetric as assumed in most tree-models. Instead abrasion or mechanisms for the avoidance of crown competition including multi layered canopy exploitation in mixed stands resulting from niche partitioning entail appreciable crown plasticity (Longuetaud et al., 2008; Pretzsch and Schütze, 2009; Seidel et al., 2011b; Takenaka, 2000). Therefore the search space does not always overlap the original target tree crown around its entire periphery. Accordingly, not every neighbor in direct contact with the target tree

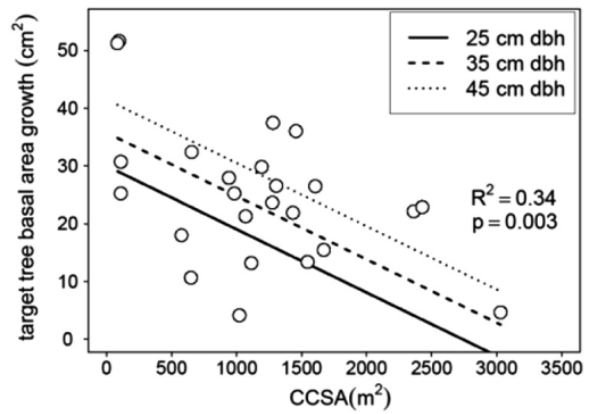

Fig. 8. Relationship between target tree basal area increment in the 2012 vegetation period and the competitive stress enforced to the trees according the model based KKLindex and the TLS-based index respectively. 

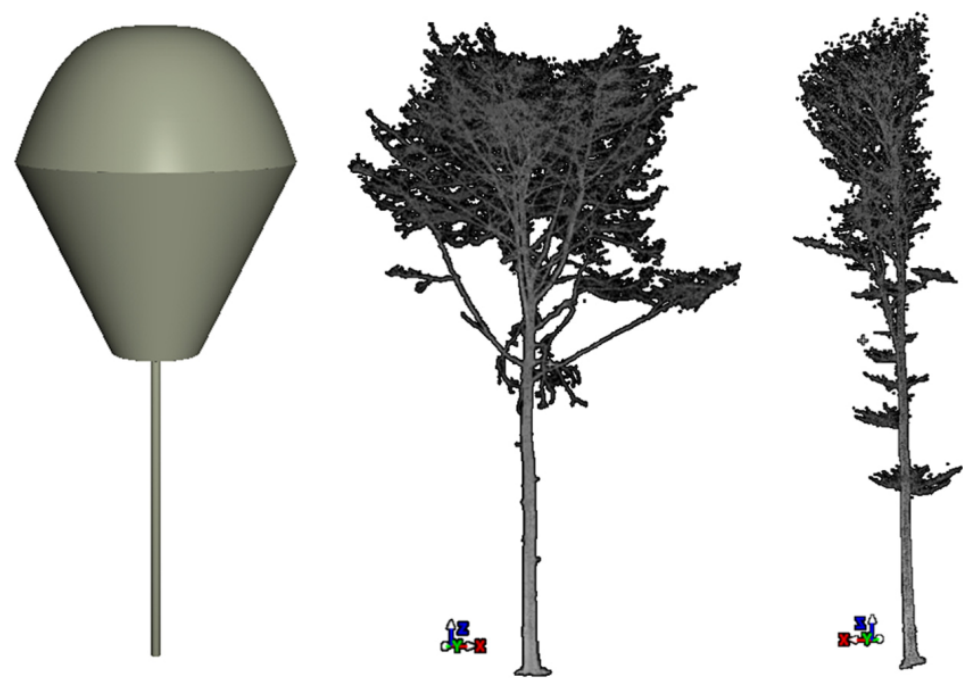

Fig. 9. TLS-derived crown shapes of two beech trees with almost the same height and dbh in comparison to the congruent geometric model.

extends its crown into the inverted search-cone. Finally even trees of the same species having similar heights and stem diameters may develop completely different crown shapes (Fig. 9) because factors such as shading or crown collision have a strong impact on morphology (Oliver and Larson, 1996; Pretzsch, 2008). The resulting variation in crown architecture can only inadequately be reproduced by geometric crown shape models.

Because of these deficiencies it is not surprising that the search cone method for competitor identification produced different results depending on the application to TLS-data or crown models. The higher degree of concordance in the selection of spruces as competitors of the focal trees could be due to a less pronounced variety of real crown shapes in the event of these conifers. That, as in the case of the laser-based CCSA, the value of a competition index and its correlation with target tree growth varies when using different methods for the competitor selection is a well known fact and has similarly been observed in other studies comparing the efficiency of competition measures in growth models (e.g. Corral Rivas et al., 2005). In fact, the high variation of both competition measures in those cases where the competitor tree species were beech or valuable hardwoods is the numeric outcome of the substantial crown variability of broadleaves, because their phenotypic or crown plasticity represents an adoption to neighborhood competition (Schröter et al., 2012; Valladares et al., 2007). Thus, the homogenous KKL and CCSA-values in case of neighborhoods composed of spruce or pine indicate that the crown expansion of these conifers is not as variable as that of the deciduous tree species (Getzin and Wiegand, 2007; Rouvinen and Kuuluvainen, 1997; Waller, 1986) leading to more uniform intertree spacing and crown extent.

It is known that the identification of neighboring trees as competitors has a decisive effect on the accuracy of increment models which can even outperform the selection of the measure for the quantification of competition itself (Bachmann, 1998). Beside this our results indicate that the inverse search cone, especially when applied to standard crown shape models, may underestimate the "true" competitors whereas its incorporation into the TLS-based crown shapes and the assessment of the expert witness are largely consistent with each other.

Thus, compared with the advisory competitor selection by crown contact the cone approach failed in 29 out of 96 cases when standard crown shapes were used and in 15 cases where the TSL- crowns were taken into account (Table 3). Consequently CCSA produced slightly better correlations between the competition index and target tree growth than CCSA $_{\text {Cone }}$ (Appendix C). However, the cone approach is a very effective and impartial way of selecting competing trees.

Light interception and tree diameter growth are highly correlated (King et al., 2005; Wyckoff and Clark, 2005), whereas height growth is less affected. Therefore, radial increment is a more sensitive indictor for competitive stress than height growth (Simard and Zimonick, 2005) because a decline in longitudinal growth reflects a serious disadvantage in light acquisition. This is why the allocation of photosynthates to height growth generally takes precedence over diameter growth (Lanner, 1985; Oliver and Larson, 1996). Thus, radial increment of heavily shaded trees abates because photosynthesis is reduced in those parts of the crown that are not or only indirectly exposed to sunlight (Oliver and Larson, 1996). Consequently, the growth potential of a tree is not exclusively determined by its own crown volume or surface, because these factors do not fully represent its effective photosynthetic active leaf area which is partly limited by the crowns of the competitors (Grote and Pretzsch, 2002; Pretzsch et al., 2011). The degree of shadowing emanating from competing neighbors substantially determines the amount and quality of solar radiation that is available for the target tree (Ballaré et al., 1990; Ballaré, 1999; Grams and Andersen, 2007). Therefore, the basic idea of calculating competition indices dealing with the so called 'exposed crown area' (ECA) is straight forward, because they quantify to what extend the growing space of a target tree is occupied by competitors (Hatch et al., 1975; Hix and Lorimer, 1990; Smith, 1994; Wyckoff and Clark, 2005). In the opinion of Davies and Pommerening (2008), through the integration of factors that specify the closest neighbors of the focal tree, model accuracy will probably be further increased because shading is materially controlled by arrangement and crown shape of nearby neighbors (Kuuluvainen and Pukkala, 1987). This seems to be verified by the results presented in this paper because in contrast to the competition index KKL, the TLSbased CCSA solely includes information about the neighbors that are identified as competitors. From all tested competitor crown parameters, cumulative crown surface area correlated best with target tree growth (Appendix F). A possible explanation why crown volume of the competitors was not the best indicator for the competitive strength of the neighbors could be, that foliage biomass is 
not evenly distributed in all compartments of the crown (Pretzsch et al., 2011; Xu and Harrington, 1998) and that assimilation, especially of the conifers, is supposed to be higher in the outer parts (Ladefoged, 1946).

Depending on light transmission of competitor crowns, a given surface is exposed to a differing amount of light. This effect is reflected in Pretzsch's formula by TM, the transmission coefficient. In fact, in our study the relationship between CCSA and growth was found to be a little stronger if TM was used. The relatively small increase of the coefficients of correlation when using TM can be related to the experimental setup of the study and the tree species involved. 48 out of 96 competitors were beech trees, whose competitive strength remains unaffected because the TM for this shade tolerant species is 1 whereas the three other groups of competitor species comprised only 16 individuals each. This may explain why the TM effect was smaller than it would have been with equal tree numbers per competitor species. Another reason for a small TM effect might be that for valuable hardwoods other than oak no species specific TM was specified what means that they were included with the same weighting as beech (TM 1) into the calculation of the competition indices. This might be an overestimation and further reduced the number of competitors with a TM value other than 1 . In summary only 33 competitors with $\mathrm{TM} \neq 1$ were available. At last, the TM assigned to spruce is 0.8 what implies that the competitive strength of this species is weakened only slightly by consideration of the transmission properties. However, TLS might be an option to quantitatively derive TM coefficients. At least for deciduous trees, this would require repeated scans of foliated and leafless trees. In case of evergreen conifer species, the density of the point cloud or the resulting number of crown voxels could probably be used to assess the transmittance of the foliage.

4.2. Impact of competing tree species on the growth response of European beech

In our study intraspecific was stronger than interspecific competition (Figs. 5 and 7, Appendix B). This may have two reasons. First, the "real" beeches had the biggest average crown surface areas. Second shade tolerant species such as beech absorb incoming light very effectively (Bonosi, 2006; Canham et al., 1994; Hagemeier, 2002) which is why their coefficient of transmission is 1 . In contrast, light demanding species such as Scots pine have smaller and more diaphanous crowns (Pacala et al., 1996). Consequently their competitive strength was much lower as indicated by both indices. Norway spruce is characterized by relatively dense foliage resulting in low light intensities at the forest floor, but their tapered crowns provide high light availability in the upper canopy. This is important as the upper parts of tree crowns have higher photosynthetically efficiency than the lower parts and therefore contribute to a larger extent to tree growth (Schulze et al., 1977; Smith et al., 1997).

No model parameterizations were available for treetop characteristics of some valuable hardwoods. The current practice to adopt the crown shapes and coefficients of transmission of beech to these species seems questionable and may lead to an overestimation of their competitive strength because in real stands they form more light-transmissive canopies (Oliver and Larson, 1996). This view is supported by our results. KKL and CCSA suggested a nearly equally strong competitive effect of the valuable hardwoods and beech on beech (Fig. 5), whereas the growth response of beech surrounded by these species was less negatively affected compared to intraspecific competition (Fig. 7). Improved nutrient supply due to complementary resource use, extenuated niche overlap and facilitation effects are presumed to be the main factors that reduce the relative effects of interspecific competition in comparison to intraspecific competition (Kelty, 2006; Pretzsch et al., 2010, 2013).
Beyond that, light availability is generally accepted to be sizeasymmetric and a key variable for growth (Brunner, 1998; Lang et al., 2010; Schwinning and Weiner, 1998) what is affirmed for individual beech trees under different competitive situations through the combination of TLS- and dendrometer measurements.

The fact that, with a few exceptions, differences in target tree basal area growth as a function of local neighborhood were not significant may have several causes. First, our analysis was focused on just one growing season. Second, the small sample sizes made statistical evaluation difficult. However, although the achieved $R^{2}$ values were not as high as in other studies (e.g. Alemdag, 1978; Filipescu and Comeau, 2007; Oheimb et al., 2011; Windhager, 1999), the results of both indices were remarkable with regard to the findings of Bachmann (1998). He stated that the link between growth and competition intensity is closer for semi-shade tolerant than for shade-tolerant tree species such as beech.

Tree growth is controlled by limited resource availability and their efficient usage in gross primary production (Binkley, 2004; Binkley et al., 2010; Grams et al., 2002). But as it is impossible to quantify these complex ecosystem interactions in its entirety (Dale et al., 1985; Schaffer, 1981) a substantial degree of growth variation remained unexplained. This might be due to the fact that in comparison to the aboveground processes described so far, root competition is considerably harder to quantify (Stiell, 1970), because water absorption, nutrient uptake and the extent of the root space cannot be measured at reasonable cost for a large number of trees. Although in the first instance the compared indices aim for the quantification of crown competition, Burton (1993) refers to the fact that belowground competition to a certain extend can indirectly be reflected in the measured aboveground parameters or processes of a tree. Pommerening (2000) agrees insofar as that the KKL describes additional competitive effects what can be transferred to the scanner-based method. Even competition indices trying to reveal the mutual competition for light are not able to simulate tree growth comprehensively because they do not comprise the underlying mechanisms in detail (Perry, 1985). The implementation of a ray-tracing canopy light model as presented from Bittner et al. (2012) or an adaptation of the search cone approach for competitor selection to seasonal variations of the solar altitude and inclined topographic conditions may contribute to further improvements in the explanation of growth patterns. However, Bachmann (1998) concludes that modifications of the KKL to the site conditions in mountain forests of different slopes and expositions did not improve the estimation accuracy of the increment models. It might be that the prevailing overcast conditions in central Germany that are hallmarked by a mean relative sunshine duration of only $39 \%$ during the growing season (Biederbick, 1992) mask the effect of competitor arrangement with respect to solar altitude.

Summing up, our hypotheses could be confirmed. First the forestry application of a terrestrial laser scanner is a suitable tool to generate precise information on canopy structure of the competitive neighborhood (Henning and Radtke, 2006). Second, a competition index derived from such information yielded higher correlation with one year target tree growth than a traditional index using standard geometric crown shape models. It is quite likely that in case of the KKL a longer measurement time and a larger sample size would have led to a clear relationship between competition and growth. This index has already proven its suitability in studies of intertree competition. Even though the increment measurements covered only one vegetation period and the amount of data was limited, the growth responses of the observed canopy trees were correlated to neighborhood diversity. Neighborhood diversity seems to substantially determine target tree growth, indicating stronger competition on beech by intra- than by interspecific interference. Nonetheless, to back up or revise these 
conclusions, long-term studies focusing on competitive interactions of important commercial tree species and investigations of the underlying mechanisms are required. To pave the way for TLS-based investigations of crown competition on the stand level, further research is needed on the development of automated methods for objective identification and skeletonization of single trees from point clouds (Bayer et al., 2013; Bucksch et al., 2009). As shown in our study the extraction by hand provides reasonable results but is very laborious. If this turns out to be successful, the use of three-dimensional measurements of canopy structure may contribute to a more profound understanding of competition processes and elude the shortcomings of geometric crown shape models or conventional methods for field measurements of crown characteristics described from Fleck et al. (2011) and Röhle (1986).

\section{Acknowledgements}

We thank the managers of the three exploratories, Swen Renner, Sonja Gockel, Andreas Hemp and Martin Gorke and Simone Pfeiffer for their work in maintaining the plot and project infrastructure, and the initiators of the Biodiversity Exploratories (these are, beside co-author Ernst-Detlef Schulze, the following people: Markus Fischer, the late Elisabeth Kalko, Eduard Linsenmair, Dominik Hessenmöller, Jens Nieschulze, Daniel Prati, Ingo Schöning, François Buscot, and Wolfgang W. Weisser) for their role in setting up the Biodiversity Exploratories project. The work has been funded by the DFG Priority Program 1374 "Infrastructure-Biodiversity-Exploratories" (Grant No: Am-149/7-1). Field work permits were issued by the responsible state environmental offices of Baden-Württemberg, Thüringen, and Brandenburg (according to $\S$ 72 BbgNatSchG). We are very grateful to Karl-Heinz Heine for assisting field work and to Jan Raacke for his graphical representations of crown shape models.

\section{Appendix A. Supplementary material}

Supplementary data associated with this article can be found, in the online version, at http://dx.doi.org/10.1016/j.foreco.2013. 08.014 .

\section{References}

Alemdag, I.S., 1978. Evaluation of Some Competition Indexes for the Prediction of Diameter Increment in Planted White Spruce. Forest Management Institute Information Report FMR-X-108. Forest Management Institute, Ottawa, Ontario.

Ammer, C., 2008. Konkurrenzsteuerung - Anmerkungen zu einer Kernaufgabe des Waldbaus beim Aufbau vielfältiger Wälder, in: Eberswalder Forstliche Schriftenreihe Band 36: Biologische Vielfalt - Lebensversicherung des Waldes. Ministerium für ländliche Entwicklung, Umwelt und Verbraucherschut (MLUV) des Landes Brandenburg, Eberswalde, pp. 21-26.

Ammer, C., Bickel, E., Kolling, C., 2008. Converting Norway spruce stands with beech - a review of arguments and techniques. Aust. J. For. Sci. 125, 3-26.

Bachmann, M., 1998. Indizes zur Erfassung der Konkurrenz von Einzelbäumen: Methodische Untersuchung in Bergmischwäldern. Forstliche Forschungsberichte München 171. Schriftenreihe der Forstwissenschaftlichen Forschungsberichte München 171. Schriftenreihe der Forstwissenschaftlichen
Fakultät der Universität München und der Bayerischen Landesanstalt für Wald Fakultät der Universität Münch
und Forstwirtschaft, München.

Ballarê, C.L., 1999. Keeping up with the neighbours: phytochrome sensing and other signalling mechanisms. Trends Plant Sci. 4, 97-102.

Ballarê, C.L., Scopel, A.L., Sanchez, R.A., 1990. Far-red radiation reflected from adjacent leaves: an early signal of competition in plant canopies. Science 247 $329-332$.

Barclay, H.J., Layton, C.R., 1990. Growth and mortality in managed Douglas fir: Relation to a comptition index. For Ecol Manage. 36, 187-204

Bartelink, H.H., 2000. Effects of stand composition and thinning in mixed-species forests: a modeling approach applied to Douglas-fir and beech. Tree Physiol. 20 399-406.

Bayer, D., Seifert, S., Pretzsch, H., 2013. Structural crown properties of Norway spruce (Picea abies [L.] Karst.) and European beech (Fagus sylvatica [L.]) in mixed versus pure stands revealed by terrestrial laser scanning. Trees, $1-13$.

Biederbick, K-H., 1992. Die direkte Sonnenstrahlung als Standortfaktor. Forstarchiv $63,131-136$.
Biging, G.S., Dobbertin, M., 1992. A comparison of distance-dependent competition measures for height and basal aerea growth of individual conifer trees. For. Sci. $38,695-720$.

Biging, G.S., Dobbertin, M., 1995. Evaluation of competition indices in individual tree growth models. For. Sci. 41, 360-377.

Biging, G.S., Wensel, L.C., 1990. Estimation of crown form for six conifer species of northern California. Can. J. For. Res. 20, 1137-1142.

Binkley, D., 2004. A hypothesis about the interaction of tree dominance and stand production through stand development. For. Ecol. Manage. 190, 265-271.

Binkley, D., Stape, J.L., Bauerle, W.L., Ryan, M.G., 2010. Explaining growth of individual trees: light interception and efficiency of light use by Eucalyptus at four sites in Brazil. For. Ecol. Manage. 259, 1704-1713.

Bittner, S., Gayler, S., Biernath, C. Winkler, J.B., Seifert, S., Pretzsch, H., Priesack, E.. 2012. Evaluation of a ray-tracing canopy light model based on terrestrial laser scans. Can. J. Remote Sens. 38, 619-628.

Bonosi, L., 2006. The influence of light and size on photosynthetic performance, light interception, biomass partitioning and tree architecture in open grown Acer pseudoplatanus, Fraxinus excelsior and Fagus sylvatica seedlings. Schriftenreihe Freiburger Forstliche Forschung Band 34. (Zugl: Freiburg, Univ., Diss., 2006. 118 S.) Fakultät für Forst- und Umweltwissenschaften, Universität Freiburg; Forstliche Versuchs- und Forschungsanstalt BadenWürttemberg, Freiburg im Breisgau.

Brunner, A., 1998. A light model for spatially explicit forest stand models. For. Ecol. Manage. 107, 19-46.

Bucksch, A. Lindenbergh, R.C., Menenti, M., 2009. SkelTre - fast skeletonisation for imperfect point cloud data of botanic trees. In: Spagnuolo, M., Pratikakis, I., Veltkamp, R.C., Theoharis, T. (Eds.), Eurographics Workshop on 3D Object Retrieval. Proceedings. Eurographics Association, Munich, pp. 13-20.

Burnham, K.P., Anderson, D.R., 2002. Model Selection and Multimodel Inference: A Practical Information-theoretic Approach, second ed. Springer, New York.

Burton, P.J., 1993. Some limitations inherent to static indices of plant competition. Can. J. For. Res. 23, 2141-2152

Canham, C.D., Finzi, A.C. Pacala, S.W. Burbank, D.H., 1994. Causes and consequences of resource heterogeneity in forests: interspecific variation in light transmission by canopy trees. Can. J. For. Res. 24, 337-349.

Canham, C.D., LePage, P.T., Coates, K.D., 2004. A neighborhood analysis of canopy tree competition: effects of shading versus crowding. Can. J. For. Res. 34,778787

Canham, C.D., Papaik, M.J., Uriarte, M., McWilliams, W.H., Jenkins, J.C., Twery, M.J., 2006. Neighborhood analyses of canopy tree competition along environmental gradients in new England forests. Ecol. Appl. 16, 540-554.

Cohen, J., 1960. A coefficient of agreement for nominal scales. Educ. Psychol. Meas. $20,37-46$.

Comeau, P.G., Heineman, J.L., 2003. Predicting understory light microclimate from stand parameters in young paper birch (Betula papyrifera Marsh.) stands. For. Ecol. Manage. 180, 303-315.

Corral Rivas, J.J., González, J.G.Á., Aguirre, O., Hernández, F.J., 2005. The effect of competition on individual tree basal area growth in mature stands of Pinus cooperi Blanco in Durango (Mexico). Eur. J. For. Res. 124, 133-142.

Dale, V.H., Doyle, T.W., Shugart, H.H., 1985. A comparison of tree growth models. Ecol. Model. 29, 145-169.

Daniels, R.F., Burkhart, H.E., Clason, T.R., 1986. A comparison of competition measures for predicting growth of loblolly pine trees. Can. J. For. Res. 16, 12301237.

Davies, O., Pommerening, A., 2008. The contribution of structural indices to the modelling of Sitka spruce (Picea sitchensis) and birch (Betula spp.) crowns. For. Ecol. Manage. 256, 68-77.

Dimov, L.D., Chambers, J.L., Lockhart, B.R., 2008. Five-year radial growth of red oaks in mixed bottomland hardwood stands. For. Ecol. Manage. 255, 2790-2800.

Ducey, M.J., Astrup, R., Pretzsch, H., Seifert, S., Larson, B.C., Coates, K.D., Tikina, A. 2011. Crown competition, crown efficiency, tree growth and site type: quantification with terrestrial LiDAR. Final Technical Report Project Y102162, Forest Investment Account (FIA), British Columbia.

Elliott, K, Vose, J., 1995. Evaluation of the competitive environment for White pine (Pinus strobus L.) seedlings planted on prescribed burn sites in the Southern Appalachians. For. Sci. 41, 513-530.

Filipescu, C.N., Comeau, P.G., 2007. Competitive interactions between aspen and white spruce vary with stand age in boreal mixedwoods. For. Ecol. Manage. 247, $175-184$.

Fischer, M., Bossdorf, O., Gockel, S., Hänsel, F., Hemp, A., Hessenmöller, D., Korte, G. Nieschulze, J., Pfeiffer, S., Prati, D., Renner, S., Schöning, L., Schumacher, U. Wells, K, Buscot, $F$, Kalko, EKV Jinsenmair KE Schulze, ED. Weisser W. 2010. Implementing large-scale and long-term functional biodiversity research: 2010. Implementing large-scale and long-term functional biod

Fleck, S., Mölder, I., Jacob, M., Gebauer, T., Jungkunst, H.F., Leuschner, C., 2011. Comparison of conventional eight-point crown projections with LIDAR-based virtual crown projections in a temperate old-growth forest. Ann. For. Sci. 68, $1173-1185$

Frech, A., 2006. Walddynamik in Mischwäldern des Nationalparks Hainich. Untersuchung der Mechanismen und Prognose der Waldentwicklung. Berichte des Forschungszentrums Waldökosysteme der Universität Göttingen Reihe A, Band 196. Forschungszentrum Waldökosysteme der Universität Göttingen, Göttingen.

Getzin. S., Wiegand, K, 2007. Asymmetric tree growth at the stand level: random crown patterns and the response to slope. For. Ecol. Manage. 242, $165-174$ 
Grams, T.E.E., Andersen, C.P., 2007. Competition for resources in trees: physiological versus morphological plasticity. In: Esser, K., Löttge, U., Beyschlag, W., Murata, J. (Eds.), Progress in Botany, vol. 68. Springer-Verlag, Berlin/Heidelberg, pp. 356381 .

Grams, T.E.E., Kozovits, A.R., Reiter, I.M., Barbro Winkler, J., Sommerkorn, M. Blaschke, H., Häberle, K.H., Matyssek, R., 2002. Quantifying competitiveness in woody plants. Plant Biol. 4, 153-158.

Grote, R., Pretzsch, H., 2002. A model for individual tree development based on physiological processes. Plant Biol. 4, 167-180.

Grouven, U., Bender, R., Ziegler, A, Lange, S., 2007. Der Kappa-Koeffizient - Artikel Nr. 23 der Statistik-Serie in der DMW. Dtsch. Med Wochenschr. 132, e65-e68.

Hagemeier, M., 2002. Funktionale Kronenarchitektur mitteleuropäischer Baumarten am Beispiel von Hängebirke, Waldkiefer, Traubeneiche, Hainbuche, Winterlinde und Rotbuche. Dissertationes Botanicae; Band 361 (Zugl.: Göttingen, Univ., Diss., 2002. 154 S.). J. Cramer in der Gebr.-Borntraeger(Zugl.: Göttingen, Univ., Diss.,

Hamilton, G., 1969. The dependence of volume increment of individual trees on dominance, crown dimensions, and competition. Forestry 42, 133-144.

Hatch, C.R., Gerrard, D.J., Tappeiner II, J.C., 1975. Exposed crown surface area: mathematical index of individual tree growth potential. Can. J. For. Res. 5, 224 228.

Henning, J.G., Radtke, P.J., 2006. Ground-based laser imaging for assessing three dimensional forest canopy structure. Photogramm. Eng. Remote Sens. 72, 13491358.

Hix, D.M., Lorimer, C.G., 1990. Growth-competition relationships in young hardwood stands on two contrasting sites in southwestern Wisconsin. For. Sci. 36, 1032-1049.

Holmes, M.J., Reed, D.D., 1991. Competition indices for mixed species northern hardwoods. For. Sci. 37, 1338-1349.

Hopkinson, C., Chasmer, L., Young-Pow, C., Treitz, P., 2004. Assessing forest metric with a ground-based scanning lidar. Can. J. For. Res. 34, 573-583.

Kelty, M.J., 2006. The role of species mixtures in plantation forestry. For. Ecol Manage. 233, 195-204.

King, D.A., Davies, S.J., Nur Supardi, M.N., Tan, S., 2005. Tree growth is related to light interception and wood density in two mixed dipterocarp forests of Malaysia. Funct. Ecol. 19, 445-453.

Knoke, T., Ammer, C., Stimm, B., Mosandl, R., 2008. Admixing broadleaved to coniferous tree species: a review on yield, ecological stability and economics. Eur. J. For. Res. 127, 89-101

Kuuluvainen, T., Pukkala, T., 1987. Effect of crown shape and tree distribution on the spatial distribution of shade. Agric. For. Meteorol. 40, 215-231.

Ladefoged, K., 1946. The productive importance of the individual parts of the crown in spruce, Picea excelsa. Det forstlige Forsogsvaesen i Danmark 16, 365-400.

Lang, A.C., Härdtle, W., Bruelheide, H., Geißler, C., Nadrowski, K., Schuldt, A., Yu, M. Oheimb, G., 2010. Tree morphology responds to neighbourhood competition Oheimb, G., 2010. Tree morphology responds to neighbourhood competition and slope in $1708-1715$.

Lanner, R.M., 1985. On the insensitivity of height growth to spacing. For. Ecol. Manage. 13, 143-148.

Larocque, G.R., 2002. Examining different concepts for the development of a distance-dependent competition model for red pine diameter growth using long-term stand data differing in initial stand density. For. Sci. 48, 24-34.

Ledermann, T., 2010. Evaluating the performance of semi-distance-independent competition indices in predicting the basal area growth of individual trees. Can. J. For. Res. 40, 796-805.

Longuetaud, F., Seifert, T., Leban, J.-M., Pretzsch, H., 2008. Analysis of long-term dynamics of crowns of sessile oaks at the stand level by means of spatial statistics. For. Ecol. Manage. 255, 2007-2019

Lorimer, C.G., 1983. Tests of age-independent competition indices for individual trees in natural hardwood stands. For. Ecol. Manage. 6, 343-360.

Martin, G.L., Ek, A.R., 1984. A comparison of competition measures and growth models for predicting plantation red pine diameter and height growth. For. Sci. 30, 731-743.

Monserud, R.A., Sterba, H., 1996. A basal area increment model for individual trees growing in even- and uneven-aged forest stands in Austria. For. Ecol. Manage. $80,57-80$.

Munro, D.D., 1974. Forest Growth Models - A Prognosis. In: Fries, J. (Ed.), Growth Models for Tree and Stand Simulation, Proceedings of the Congress IUFRO S4.01-4. Department of Forest Yield Research, Royal College of Forestry, Stockholm, pp. 7-21.

Oliver, C.D., Larson, B.C., 1996. Forest Stand Dynamics, Update ed. Wiley, New York

Pacala, S.W., Canham, C.D., Saponara, J., Silander, J.A., Kobe, R.K., Ribbens, E., 1996. Forest models defined by field measurements: estimation, error analysis and dynamics. Ecol. Monogr. 66, 1-43.

Perot, T., Goreaud, F., Ginisty, C., Dhôte, J.-F., 2010. A model bridging distancedependent and distance-independent tree models to simulate the growth of mixed forests. Ann. For. Sci. 67, 502p1-502p11.

Perry, D.A., 1985. The competition process in forest stands. In: Cannel, M.G., Jackson J.E. (Eds.), Attributes of Trees as Crop Plants. Institute of Terrestrial Ecology, Abbots Ripton, pp. 481-506.

Pommerening, A., 2000. Methoden zur Reproduktion und Fortschreibung einzelner konzentrischer Probekreise von Betriebs - und Landeswaldinventuren. (Methods for simulating stand structure and updating single concentric sample plots from inventories of forest enterprises and national forest inventories). Forstarchiv 71 190-199.
Portê, A., Bartelink, H., 2002. Modelling mixed forest growth: a review of models for forest management. Ecol. Model. 150, 141-188.

Pretzsch, H., 1995. Zum Einfluß des Baumverteilungsmusters auf den Bestandeszuwachs: on the effect of the spatial distribution of trees on the stand growth. Allg. Forst- $u$. Jagdztg. 166, 190-201.

Pretzsch, H., 2001. Modellierung des Waldwachstums. Blackwell WissenschaftsVerlag GmbH, Berlin/Wien.

Pretzsch, H., 2008. Wirkung von Stress auf die Allometrie von Baumkronen. In: Nagel, J. (ed.), Beiträge zur Jahrestagung der Sektion Ertragskunde im Deutschen Verband Forstlicher Forschungsanstalten, Göttingen, pp. 5-21.

Pretzsch, H., Schütze, G., 2005. Crown allometry and growing space efficiency of Norway spruce (Picea abies [L.] Karst.) and European beech (Fagus sylvatica L.) in pure and mixed stands. Plant Biol. 7, 628-639.

Pretzsch, H., Schütze, G., 2009. Transgressive overyielding in mixed compared with pure stands of Norway spruce and European beech in Central Europe: evidence on stand level and explanation on individual tree level. Eur. J. For. Res. 128 , 183-204.

Pretzsch, H., Biber, P., Ďurský, J., 2002. The single tree-based stand simulator SILVA: construction, application and evaluation. For. Ecol. Manage. 162, 3-21.

Pretzsch, H., Block, J., Dieler, J., Dong, P.H., Kohnle, U., Nagel, J., Spellmann, H., Zingg, A., 2010. Comparison between the productivity of pure and mixed stands of Norway spruce and European beech along an ecological gradient. Ann. For. Sci. 67, 712p1-712p12.

Pretzsch, H., Seifert, S., Huang, P., 2011. Beitrag des terrestrischen Laserscannings zur Erfassung der Struktur von Baumkronen (Application of terrestrial laser scanning for measuring tree crown structures). Schweiz. Z. Forstwes. 162, 186194.

Pretzsch, H., Bielak, K, Block, J., Bruchwald, A., Dieler, J., Ehrhart, H.-P., Kohnle, U., Nagel, J., Spellmann, H., Zasada, M., Zingg, A, 2013. Productivity of mixed versus pure stands of oak (Quercus petraea (Matt.) Liebl. and Quercus robur L.) and European beech (Fagus sylvatica L.) along an ecological gradient. Eur. J. For. Res. $132,263-280$.

Purves, D.W., Lichstein, J.W., Pacala, S.W., 2007. Crown plasticity and competition for canopy space: a new spatially implicit model parameterized for 250 North American tree species. PLoS One 2, e870.

R Development Core Team, 2012. R: A language and environment for statistical computing. R Foundation for Statistical Computing, Vienna, Austria (ISBN: 3900051-07, <http:/(www.R-project.org>).

Röhle, H., 1986. Vergleichende Untersuchungen zur Ermittlung der Genauigkeit bei der Ablotung von Kronenradien mit dem Dachlot und durch senkrechtes Anvisieren des Kronenrandes (Hochblick-Messung). Forstarchiv 57, 67-71.

Rouvinen, S., Kuuluvainen, T., 1997. Structure and asymmetry of tree crowns in relation to local competition in a natural mature Scots pine forest. Can. J. For. Res. 27, 890-902.

Schaffer, W.M., 1981. Ecological abstraction: the consequences of reduced dimensionality in ecological models. Ecol. Monogr. 51, 383-401.

Schröter, M., Härdtle, W., Oheimb, G., 2012. Crown plasticity and neighborhood interactions of European beech (Fagus sylvatica L.) in an old-growth forest. Eur. J. For. Res. 131, 787-798

Schulze, E.-D., Fuchs, M.I., Fuchs, M., 1977. Spacial distribution of photosynthetic capacity and performance in a mountain spruce forest of Northern Germany. Oecologia $29,43-61$.

Schwinning, S., Weiner, J., 1998. Mechanisms determining the degree of size asymmetry in competition among plants. Oecologia 113, 447-455.

Seidel, D., Beyer, F., Hertel, D., Fleck, S., Leuschner, C., 2011a. 3D-laser scanning: a non-destructive method for studying above-ground biomass and growth of juvenile trees. Agric. For. Meteorol. 151, 1305-1311.

Seidel, D., Leuschner, C., Müller, A., Krause, B., 2011b. Crown plasticity in mixed forests-quantifying asymmetry as a measure of competition using terrestrial laser scanning. For. Ecol. Manage. 261, 2123-2132.

Seifert, S., 2012. Bestimmung des Einflusses der Kronenform und der lokalen Konkurrenz auf den Zuwachs von Nadelbäumen mit Hilfe terrestrischer Laserscannerdaten. In: Clasen, M., Fröhlich, G., Bernhardt, H., Hildebrand, K., Theuvsen, B. (Eds.), Lecture Notes in Informatics - Informationstechnologie für eine nachhaltige Landbewirtschaftung. Gesellschaft für Informatik, Bonn, pp. eine nach $275-278$.

Shi, H., Zhang, L., 2003. Local analysis of tree competition and growth. For. Sci. 49 , 938-955.

Simard, S.W., Zimonick, B.J., 2005. Neighborhood size effects on mortality, growth and crown morphology of paper birch. For. Ecol. Manage. 214, 251-265.

Smith, W., 1994. An empirical evaluation of a three-dimensional crown model for predicting volume growth. For. Ecol. Manage. 69, 199-209.

Smith, D.M., Larson, B.C., Kelty, M.J., Ashton, P.M.S., 1997. The practice of silviculture: Applied forest ecology, ninth ed. Wiley, New York.

Solly, E., Schöning, I., Boch, S., Müller, J., Socher, S.A., Trumbore, S.E., Schrumpf, M., 2013. Mean age of carbon in fine roots from temperate forests and grasslands with different management. Biogeosci. Discuss. 10, 5671-5700.

Stiell, W.M., 1970. Some Competitive Relations in a Red Pine Plantation. Publication No. 1275. Dept. of Fisheries and Forestry, Canadian Forestry Service, Ottawa.

Takenaka, A, 2000. Shoot growth responses to light microenvironment and correlative inhibition in tree seedlings under a forest canopy. Tree Physiol. 20 , 987-991.

Thorpe, H., Astrup, R., Trowbridge, A., Coates, K, 2010. Competition and tree crowns: a neighborhood analysis of three boreal tree species. For. Ecol. Manage. 259, 1586-1596. 
Tomê, M., Burkhart, H.E., 1989. Distance-dependent competition measures for predicting growth of individual trees. For. Sci. 35, 816-831.

Townsend, C., Harper, J., Begon, M., 2003. Ökologie. Springer-Verlag, Berlin/ Heidelberg.

Valladares, F., Gianoli, E., Gómez, J.M., 2007. Ecological limits to plant phenotypic plasticity. New Phytol. 176, 749-763.

van der Zande, D., Jonckheere, I., Stuckens, J., Verstraeten, W.W., Coppin, P., 2008. Sampling design of ground-based lidar measurements of forest canopy structure and its effect on shadowing. Can. J. Remote Sens. 34, 526-538.

von Oheimb, G., Lang, A.C., Bruelheide, H., Forrester, D.I., Wäsche, I., Yu, M., Härdtle, W., 2011. Individual-tree radial growth in a subtropical broad-leaved forest: the role of local neighbourhood competition. For. Ecol. Manage. 261, 499-507.

Waller, D.M., 1986. The dynamics of growth and form. In: Crawley, M.J. (Ed.), Plant Ecology. Blackwell Scientific Publications Ltd., Oxford, pp. 291-320.
Weigelt, A., Jolliffe, P., 2003. Indices of plant competition. J. Ecol. 91, 707-720. Windhager, M., 1999. Vergleich von distanzabhängigen und unabhängigen konkurrenzbeschreibenden Faktoren und ihre Auswirk ungen auf den Grundflächenzuwachs. Allg. Forst- u. J.-Ztg. 170, 133-136.

Wyckoff, P.H. Clark, J.S., 2005. Tree growth prediction using size and exposed crown area. Can. J. For. Res. 35, 13-20.

Xu, M., Harrington, T., 1998. Foliage biomass distribution of loblolly pine as affected by tree dominance, crown size, and stand characteristics. Can. J. For. Res. 28, $887-892$.

Zhao, D., Borders, B., Wilson, M., Rathbun, S.L., 2006. Modeling neighborhood effects on the growth and survival of individual trees in a natural temperate speciesrich forest. Ecol. Model. 196, 90-102. 


\section{Supplementary material}

Appendix A: Absolute measurement errors of tree parameters selected for the comparator check.

\begin{tabular}{lcc}
\hline \multicolumn{1}{c}{ parameter } & mean & $\mathbf{\pm}$ SD \\
\hline$\Delta$ Total Tree Height $[\mathrm{m}]$ & 0.24 & 0.28 \\
$\Delta$ DBH $[\mathrm{cm}]$ & 0.21 & 0.22 \\
Distance between stem base points [m] & 0.00 & 0.00 \\
$\Delta$ HmaxArea [m] & 0.23 & 0.30 \\
$\Delta$ MaxArea $\left[\mathrm{m}^{2}\right]$ & 3.02 & 3.45 \\
Distance between crown centers [m] & 0.35 & 0.30 \\
$\Delta$ Crown direction $\left[{ }^{\circ}\right]$ & 8.47 & 9.66 \\
$\Delta$ Asymmetry $[\mathrm{m}]$ & 0.25 & 0.28 \\
$\Delta$ CBH $[\mathrm{m}]$ & 0.67 & 1.34 \\
\hline
\end{tabular}

Appendix B: Measures of dispersion and correlation coefficients for both competition indices.

\begin{tabular}{|c|c|c|c|c|c|c|c|c|c|c|}
\hline \multirow{2}{*}{ Competitor tree species } & \multicolumn{2}{|c|}{ KKL } & \multicolumn{2}{|c|}{$\mathrm{CCSA}_{\text {cone }}$} & \multicolumn{6}{|c|}{ CCSA } \\
\hline & mean & \pm SD & mean & \pm SD & $\begin{array}{c}\mathbf{r} \\
\text { (rho) }\end{array}$ & $\mathbf{p}$ & mean & \pm SD & $\begin{array}{c}\mathbf{r} \\
\text { (rho) }\end{array}$ & $\mathbf{p}$ \\
\hline beech & 0.45 & 0.21 & 1487.13 & 527.16 & \multirow{4}{*}{$\begin{array}{l}0.5276 \\
(0.6452)\end{array}$} & \multirow{4}{*}{$\begin{array}{c}0.008 \\
(0.001)\end{array}$} & 1636.99 & 632.32 & \multirow{4}{*}{$\begin{array}{c}0.5181 \\
(0.6304)\end{array}$} & \multirow{4}{*}{$\begin{array}{l}0.009 \\
(0.001)\end{array}$} \\
\hline valuable hardwood & 0.29 & 0.15 & 1001.21 & 603.58 & & & 1241.37 & 329.65 & & \\
\hline spruce & 0.04 & 0.04 & 601.63 & 216.95 & & & 749.00 & 246.06 & & \\
\hline pine & 0.02 & 0.01 & 66.88 & 34.36 & & & 98.42 & 12.52 & & \\
\hline
\end{tabular}

Appendix C: Target tree basal area growth $\left[\mathrm{cm}^{2}\right]$ and its relationship to the competition indices tested in this study.

\begin{tabular}{|c|c|c|c|c|c|c|c|c|c|}
\hline \multirow[b]{2}{*}{ competitor tree species } & \multicolumn{3}{|c|}{ basal area incr. $\left[\mathrm{cm}^{2}\right]$} & \multicolumn{2}{|c|}{ KKL } & \multicolumn{2}{|c|}{$\mathrm{CCSA}_{\text {cone }}$} & \multicolumn{2}{|c|}{ CCSA } \\
\hline & mean & $\pm \mathrm{SD}$ & $\begin{array}{c}\text { cov } \\
{[\%]}\end{array}$ & $\mathbf{r}$ & p & $\mathbf{r}$ & $\mathbf{p}$ & $\mathbf{r}$ & p \\
\hline beech & 21.45 & 10.68 & 49.79 & \multirow{4}{*}{-0.3181} & \multirow{4}{*}{0.1298} & \multirow{4}{*}{-0.4755} & \multirow{4}{*}{0.0189} & \multirow{4}{*}{-0.4896} & \multirow{4}{*}{0.0152} \\
\hline valuable hardwood & 25.39 & 2.58 & 10.15 & & & & & & \\
\hline spruce & 18.56 & 9.72 & 52.37 & & & & & & \\
\hline pine & 39.71 & 13.72 & 34.56 & & & & & & \\
\hline
\end{tabular}


Appendix D.1: Adjusted p-values for the multiple comparison of mean with Wilcoxon's rank sum test.

\begin{tabular}{|c|c|c|c|c|c|}
\hline \multirow{3}{*}{ comparison of mean } & \multicolumn{5}{|c|}{ adjusted p-values } \\
\hline & \multirow[t]{2}{*}{ KKL } & \multirow[t]{2}{*}{$\mathbf{C C S A}_{\text {cone }}$} & \multirow[t]{2}{*}{ CCSA } & \multicolumn{2}{|c|}{ target tree basal area incr. } \\
\hline & & & & $\%$ & $\mathrm{~cm}^{2}$ \\
\hline beech vs. valuable hardwood & 0.6198 & 1.0 & 1.0 & 1.0 & 1.0 \\
\hline beech vs. spruce & 0.0066 & 0.0066 & 0.0264 & 1.0 & 1.0 \\
\hline beech vs. pine & 0.0066 & 0.0066 & 0.0066 & 0.013 & 0.18 \\
\hline valuable hardwood vs. pine & 0.1714 & 0.1714 & 0.1714 & 0.686 & 0.69 \\
\hline spruce vs. pine & 1.0 & 0.1714 & 0.1714 & 1.0 & 0.69 \\
\hline spruce vs. valuable hardwood & 0.1714 & 1.0 & 0.6857 & 1.0 & 1.0 \\
\hline
\end{tabular}

Appendix D.2: Adjusted p-values of the nonparametric multiple comparison (type of contrast: Tukey).

\begin{tabular}{lccccc}
\hline & \multicolumn{5}{c}{ adjusted p-values } \\
\cline { 2 - 6 } comparison of mean & KKL & $\mathbf{C C S A}_{\text {cone }}$ & $\mathbf{C C S A}$ & \multicolumn{2}{c}{ target tree basal area incr. } \\
\cline { 2 - 6 } & & & & {$[\%]$} & $\mathbf{c m}^{\mathbf{2}}$ \\
beech vs. valuable hardwood & 0.466 & 0.924 & 0.863 & 0.879 & 0.876 \\
beech vs. spruce & 0.000 & 0.000 & 0.012 & 0.986 & 0.947 \\
beech vs. pine & 0.000 & 0.000 & 0.000 & 0.003 & 0.073 \\
valuable hardwood vs. pine & 0.000 & 0.000 & 0.000 & 0.386 & 0.366 \\
spruce vs. pine & 0.787 & 0.000 & 0.000 & 0.888 & 0.365 \\
spruce vs. valuable hardwood & 0.000 & 0.996 & 0.441 & 1.0 & 0.867 \\
\hline
\end{tabular}

Appendix E: Evaluation of all candidate lme-model fits using the information-theoretic AICcapproach.

\begin{tabular}{|c|c|c|c|}
\hline \multicolumn{4}{|c|}{ Ime $(\Delta$ basal area $\sim$ model, random $=\sim 1 \mid$ exploratory) } \\
\hline model & AICc & AICc Weight & Pseudo $\mathbf{R}^{2}$ \\
\hline $\mathrm{CCSA}^{*}+\mathrm{dbh}$ & 189.73 & 0.25 & 0.34 \\
\hline $\mathrm{CCSA}^{*}$ & 189.82 & 0.23 & 0.24 \\
\hline $\mathrm{CCSA}_{\mathrm{Cone}} *$ & 190.25 & 0.19 & 0.23 \\
\hline $\mathrm{CCSA}_{\text {Cone }}{ }^{*}+\mathrm{dbh}$ & 190.90 & 0.14 & 0.30 \\
\hline $\mathrm{CCSA}+\mathrm{dbh}+\mathrm{CCSA}: \mathrm{dbh}$ & 192.36 & 0.07 & 0.36 \\
\hline $\mathrm{CCSA}_{\mathrm{Cone}}+\mathrm{dbh}+\mathrm{CCSA}: \mathrm{dbh}$ & 193.22 & 0.04 & 0.34 \\
\hline only intercept & 193.50 & 0.04 & 0 \\
\hline KKL & 193.84 & 0.03 & 0.10 \\
\hline dbh & 196.40 & 0.01 & 0 \\
\hline $\mathrm{KKL}+\mathrm{dbh}$ & 197.00 & 0.01 & 0.10 \\
\hline$K K L+d b h+K K L: d b h$ & 199.81 & 0.00 & 0.13 \\
\hline Signif. code: $\leq 0.05^{\prime} *$ ' & & & \\
\hline
\end{tabular}


Appendix F: Correlations of tested competitor crown parameters with target tree basal area growth.

\begin{tabular}{|c|c|c|c|}
\hline \multicolumn{2}{|c|}{ crown parameter* } & $\mathbf{r}$ & p-value \\
\hline \multicolumn{2}{|c|}{$\Sigma$ competitor crown volume located inside cone } & -0.42 & 0.04 \\
\hline \multicolumn{2}{|c|}{$\Sigma$ crown volume of selected neighbors } & -0.42 & 0.04 \\
\hline \multicolumn{2}{|c|}{$\Sigma$ crown volume of all neighbors } & -0.42 & 0.04 \\
\hline \multicolumn{2}{|c|}{$\Sigma$ of crown voxels corresponding to selected neighbors } & -0.45 & 0.03 \\
\hline \multicolumn{2}{|c|}{$\Sigma$ of crown voxels corresponding to all neighbors } & -0.48 & 0.02 \\
\hline \multicolumn{2}{|l|}{$\mathrm{CCSA}_{\mathrm{Cone}}$} & -0.48 & 0.02 \\
\hline \multicolumn{2}{|l|}{ CCSA } & -0.49 & 0.02 \\
\hline \multicolumn{2}{|l|}{ KKL } & -0.32 & 0.13 \\
\hline \multicolumn{4}{|c|}{ * parameters weighted with species specific coefficients of transmission } \\
\hline \multicolumn{4}{|c|}{ beech $\quad 1$} \\
\hline \multicolumn{4}{|c|}{ spruce $\quad 0.8$} \\
\hline \multicolumn{4}{|l|}{ oak } \\
\hline \multicolumn{4}{|l|}{ pine } \\
\hline \multicolumn{2}{|l|}{ valuable hardwood } & & \\
\hline
\end{tabular}




\title{
Chapter 3
}

Site-adapted admixed tree species reduce drought susceptibility of mature European beech

\author{
Jérôme Metz • Peter Annighöfer • Peter Schall • Jorma Zimmermann \\ - Tiemo Kahl • Ernst-Detlef Schulze • Christian Ammer
}

\author{
Reprinted by permission from John Wiley and Sons \\ Journal publisher: John Wiley \& Sons Ltd \\ Journal name: Global Change Biology \\ Article name: Site-adapted admixed tree species reduce drought susceptibility of mature \\ European beech \\ Authors: Metz J, Annighöfer P, Schall P, Zimmermann J, Kahl T, Schulze E-D, Ammer C \\ Copyright: John Wiley \& Sons Ltd 2015 \\ Year of publication: 2016 \\ DOI: $10.1111 /$ gcb.13113 \\ Glob Change Biol
}

The final publication is available at:

https://onlinelibrary.wiley.com/doi/abs/10.1111/gcb.13113 


\title{
Site-adapted admixed tree species reduce drought susceptibility of mature European beech
}

\author{
JÉRÔME METZ ${ }^{1}$, PETER ANNIGHÖFER ${ }^{1}$, PETER SCHALL ${ }^{1}$, JORMA ZIMMERMANN ${ }^{2}$, \\ TIEMO KAHL ${ }^{3}$, ERNST-DETLEF SCHULZE ${ }^{4}$ and CHRISTIAN AMMER ${ }^{1}$ \\ ${ }^{1}$ Department of Silviculture and Forest Ecology of the Temperate Zones, Faculty of Forest Sciences and Forest Ecology, University \\ of Göttingen, Büsgenweg 1, 37077 Göttingen, Germany, ${ }^{2}$ Albrecht von Haller Institute for Plant Sciences, Plant Ecology and \\ Ecosystem Research, University of Göttingen, Grisebachstraße 1 and 1 a, 37077 Göttingen, Germany, ${ }^{3}$ Silviculture, \\ Albert-Ludwigs-University Freiburg, Tennenbacherstraße 4, 79085 Freiburg, Germany, ${ }^{4}$ Max-Planck-Institute for \\ Biogeochemistry, Hans-Knoell-Straße 10, 07745 Jena, Germany
}

\begin{abstract}
Some forest-related studies on possible effects of climate change conclude that growth potential of European beech (Fagus sylvatica L.) might be impaired by the predicted increase in future serious drought events during the growing season. Other recent research suggests that not only multiyear increment rates but also growth resistance and recovery of beech during, respectively, after dry years may differ between pure and mixed stands. Thus, we combined dendrochronological investigations and wood stable isotope measurements to further investigate the impact of neighborhood diversity on long-term performance, short-term drought response and soil water availability of European beech in three major geographic regions of Germany. During the last four decades, target trees whose competitive neighborhood consisted of co-occurring species exhibited a superior growth performance compared to beeches in pure stands of the same investigation area. This general pattern was also found in exceptional dry years. Although the summer droughts of 1976 and 2003 predominantly caused stronger relative growth declines if target trees were exposed to interspecific competition, with few exceptions they still formed wider annual rings than beeches growing in close-by monocultures. Within the same study region, recovery of standardized beech target tree radial growth was consistently slower in monospecific stands than in the neighborhood of other competitor species. These findings suggest an improved water availability of beech in mixtures what is in line with the results of the stable isotope analysis. Apparently, the magnitude of competitive complementarity determines the growth response of target beech trees in mixtures. Our investigation strongly suggest that the sensitivity of European beech to environmental constrains depends on neighborhood identity. Therefore, the systematic formation of mixed stands tends to be an appropriate silvicultural measure to mitigate the effects of global warming and droughts on growth patterns of Fagus sylvatica.
\end{abstract}

Keywords: beech, climate change, competition, drought stress, stable isotopes, tree rings

Received 3 May 2015 and accepted 9 September 2015

\section{Introduction}

European beech (Fagus sylvatica L.) grows vigorously under a broad range of environmental conditions and mixture types, due to its interspecific competitiveness (Ellenberg, 1996; Leuschner, 1998) and wide ecological amplitude (Leuschner et al., 2006). Hence, this broadleaf tree species is preferentially used for the conversion of coniferous monocultures into mixed stands, which is a primary objective of most Central European forest management concepts (Knoke et al., 2008; BMELV, 2009; Scharnweber et al., 2011). On suitable soils, beech-dominated commercial forests have also been enriched by fast growing and profitable conifers for financial reasons. Regardless of stand formation, multispecies forests are expected to better cope with

Correspondence: Jérôme Metz, tel. +49551 3933671 , fax +49 55139 33270, e-mail: jmetz@gwdg.de future ecological and economic challenges as well as risks resulting from the long production period inherent to forest ecosystems (Knoke et al., 2008). Therefore, European beech always was and still is one of the most prevalent and important commercial tree species in Central European forestry (Ellenberg, 1996; Tegel $e t$ al., 2014). Several studies on possible effects of climate change came to the conclusion that despite of its pronounced potential for adaptation to various site conditions, vigor, gross primary production and regeneration of European beech might be susceptible to expected future serious drought events during the growing season (e.g. Rennenberg et al., 2004; Ciais et al., 2005; Czajkowski et al., 2005; Jump et al., 2006; Piovesan et al., 2008; Aertsen et al., 2014), primarily on soils with low water retention capacity (Fotelli et al., 2003). Such suppositions require closer scrutiny as reliable scenarios predict not only a further temperature 
increase but also a higher frequency of dry periods in summer for large parts of European beech's natural range (Schär et al., 2004; Christensen et al., 2007). If Fagus sylvatica reacted to changing growing conditions as sensitive as repeatedly assumed, this would have profound commercial and ecological implications (Fotelli $e t$ al., 2009) for forest owners, timber-processing industries or environmental protection objectives including carbon sequestration goals (Ciais et al., 2005).

While it is well known that in the temperate zones, water availability is one of the most important determinants for annual increment of single trees and whole stands (Bréda et al, 2006), the complex interdependencies between tree species richness and maintenance of forest ecosystem productivity within drought years or across several vegetation periods are still not fully understood (Larsen, 1995; DeClerck et al., 2006; Mölder et al., 2011). Hence, to develop future-orientated management strategies, deeper insights into the effect of water scarcity on growth (Lebourgeois et al., 2005) and physiological response of European beech (e.g. Bréda et al., 2006; Fotelli $e t$ al., 2009) in pure and mixed stands are necessary. In a previous investigation, we found that neighborhood identity had a strong effect on interspecific competition and hence on 1-year basal area increment of European beech (Metz et al, 2013). Other studies revealed that beech growth responses to climate vary significantly as a function of the intraspecific competition level (Piutti \& Cescatti, 1997; Cescatti \& Piutti, 1998). However, the question remains how intra- and interspecific competition affects multidecadal growth rates and especially the drought response of mature European beech (Mölder et al., 2011; Pretzsch et al., 2012, 2013; Mölder \& Leuschner, 2014). Consequently, beside long-term ring-width chronologies, this study particularly examined the impact of periods with substantial rainfall deficits as observed in 1976 and 2003 on wood stable isotope ratios as well as resistance, recovery and resilience of radial beech target tree growth in different competitive neighborhoods.

The combination of dendrochronological investigations and measurements of carbon isotope composition is a suitable tool to assess the influence of forest management, neighborhood identity and competition on productivity and tree water-use efficiency (cp. McDowell et al., 2006; Di Matteo et al., 2010; Eilmann et al., 2010; Mölder $e_{t}^{t}$ al., 2011). Nonetheless, to our knowledge, the investigation on hand is the first one that analyzed the impact of different conifer species as competitors on growth and wood carbon isotope ratios of target beech trees. So far, the combined approach has only been used in broad-leaved mixed forests with Fagus sylvatica as main species (Mölder et al., 2011). Hence, we expect insights on how beech may respond to future climate and droughts in pure and various mixed stands.

Against this background, we hypothesized that if competitor trees are of comparable size and equal in number, within a particular growing area:

1. Mean ring width of European beech trees is higher when exposed to inter- than to intraspecific competition over a period of four decades.

2. In extremely dry years, radial increment of beeches that are exclusively surrounded by other tree species is less seriously affected and regains predrought growth level faster than target trees in the neighborhood of conspecifics.

3. During 4-year periods which include the low-precipitation pointer years 1976 and 2003, intraspecific interference entails higher water stress levels and hence less negative wood $\delta^{13} \mathrm{C}$-values of target beech trees than local neighborhoods composed of cooccurring species.

\section{Materials and methods}

\section{Study area}

The target tree beeches used in this study grow on forest field plots that are part of the German Biodiversity Exploratories project (http://www.biodiversity-exploratories.de/). Spread over three major geographic regions, it comprises a network of permanent and uniformly structured study plots along gradients of land-use intensity ranging from forests managed in varying intensity to stands which have been unmanaged since decades. In the Thuringian Hainich-Dün region and in the two Biosphere Reserves Schortheide-Chorin, situated northeast of Berlin, as well as Swabian Alb which is located in the State of Baden-Württemberg, 50 forest plots each were established during the project implementation phase in 2006 (Fig. S1; Fischer et al., 2010). In all three Exploratories, beech occurs in pure and mixed stands. However, as the site conditions differ between the study regions (Fig. S1), the main admixed tree species vary depending on the investigation area. While in the glacially formed Schorfheide-Chorin area that is characterized by very low amounts of precipitation, Scots Pine (Pinus sylvestris) is most frequent, mixed stands on the richer soils in the Hainich-Dün region contain high proportions of valuable hardwoods (e.f. Fraxinus excelsior, Acer pseudoplatanus, Querous spec. or Tilia cordata). The higherelevated and more humid Swabian Alb sites are dominated by Picea abies-Fagus sylvatica mixtures. From the 150 forest field plots, a subset of 17 pure and mixed stands comparable in age and mean tree diameter were selected (cp. Metz et al., 2013). Twenty-four target beech trees, each surrounded by four competitors of similar size and distance, were determined on these plots (Table 1 and Metz et al, 2013). At every Exploratory, eight groups each consisting of one target tree and four competing neighbors were identified $(\rightarrow$ three Exploratories $\times$ eight groups $\times$ five trees $=120$ trees). The 


\section{MIXTURES IMPROVE WATER AVAILABILITY OF BEECH 905}

standardized groups were composed as follows (Table 1): Additionally to four pure European beech groups in each of the three Exploratories, the effects of interspecific competition were investigated by inclusion of four other beech target trees per region being surrounded either by four Scots pines (Schorfheide-Chorin area), by four valuable hardwoods (mainly sycamore maple or European ash) at the Hainich-Dün sites or by four Norway spruce trees (Swabian Alb plots).

The criteria for the selection of the target trees were (cp. Metz et al., 2013) as follows:

1. If possible, diameter at breast height (dbh) of target beech trees between 30 and $50 \mathrm{~cm}$, to minimize effects of the developmental phase on natural biological growth rates in the forefront of the detrending procedure. Although the mean $\mathrm{dbh}$ of the target trees differed between sites (Table 1), within the same Exploratory, the sizeratio of mean target tree diameter to mean competitor tree diameter was rather constant (Schorfheide: intraspecific competition $=0.86$, interspecific competition $=0.88$; Hainich: intraspecific competition $=0.83$, interspecific competition $=$ 0.83; Swabian Alb: intraspecific competition $=0.96$, interspecific competition $=0.87$ )

2. All trees belong to the forest overstory, because (co-) dominant trees are expected to be more drought sensitive than suppressed ones (Martín-Benito et al., 2008; Mérian \& Lebourgeois, 2011; van der Maaten, 2012; Zang et al., 2012).

3. As far as visually discernible (e.g. stumps and canopy gapsi, target tree growth during the period under investigation should not be affected by harvesting operations or natural disturbances

4. All target trees are enclosed by four competing neighbors that must be grouped symmetrically and at equal distance to the focal beech.

Investigations were restricted on stands with a minimum of understory vegetation or regeneration, to ensure that potential causes for observed differences in radial increment and $\delta^{13} \mathrm{C}$ were limited to climate and varying amounts of intertree competition between the mature trees only. Two different competition measures (Table 1) were calculated individually for each target tree (cp. Metz et al, 2013). They quantify the competition by neighboring trees based on their height, crown surface or cross-sectional area and transmissibility for light which is determined by species identity (cp. Metz et al, 2013). While CCSA Cone $_{\text {(competitors' crown surface area of the trees }}$ selected by a search cone) is derived from terrestrial laser scanning (TLS), Pretzsch's index KKL (Pretzsch, 1995) is based on geometric crown shape models.

\section{Preparation and analysis of core samples}

In July 2012, all 24 target trees were cored with Suunto increment borers (drilling depth: 300 and $400 \mathrm{~mm}$; bore diameter: $5 \mathrm{~mm}$ ) at breast height. Except for two beeches, we retrieved undamaged core sample pairs at an angle of $90^{\circ}$ from those parts of the log that were free of twig scars, bark injuries or external signs of reaction wood. A core microtome (cp. Gärtner \& Nievergelt, 2010) was utilized for the cutting of the watered increment cores resulting in smooth surfaces. As it can be difficult to clearly identify narrow or blurred tree-ring borders of European beech because of the diffuse-porous wood anatomy, all increment cores were scanned with a resolution of $2400 \mathrm{dpi}$ and stored as bmp.-files. Using the software Lignovision ${ }^{\mathrm{TM}}$ (version 1.38; RINNTECH, Heidelberg, Germany), tree-ring boarders were marked manually with a precision of 1 / $100 \mathrm{~mm}$. The analysis of competition-related growth patterns focused on the period 1970-2011 for two reasons. Firstly, global warming was intense during the last four decades, with an average earth surface temperature increase of about $0.5^{\circ} \mathrm{C}$ (Intergovernmental Panel on Climate Change (IPCC), 2007). For the corresponding period, evaluation of climate data from all Exploratories revealed rises in temperatures during the growing season that were even about three times the global rate (cp. Section climate data \& Fig. S2). Secondly, it was impossible to gain reliable information on changes concerning the competitive neighborhood of our target trees that may have occurred in the more distant past as a consequence of natural disturbances or management interventions.

\section{Data processing}

Cross-dating and time series editing were conducted using the program TSAP-Win Professional (version 4.68; RINNTECH). After evaluating the synchronicity of both radial series from the same tree by identifying false, missing or wedging rings, tree mean curves could be built from the two individual series. This kind of averaging is recommended because it weakens the effect of eccentric radial growth. Correct dating of the tree mean curves from the same Exploratory had to be verified by testing them not only mutually but also against the site chronologies from beech trees of pure and mixed stands. These data had previously been calculated for every Exploratory by combining all samples of a subpopulation to a mean time series. For final control, their synchronous position was additionally compared to reference curves from the three study sites that were provided by one of our partner projects from the Biodiversity Exploratories research platform. Chronologies were considered as correctly cross-dated if the $t$-value (Baillie \& Pilcher, 1973) exceeded a threshold of 3.5 (cp. Mölder et al., 2011), the GL-value ('Gleichläufigkeit' according to Eckstein \& Bauch, 1969) was at least $65 \%$ (cp. Dulamsuren et al., 2010) and the CDI (Cross Date Index) greater than 20 (cp. Müller, 2007).

To make annual ring widths of different series comparable by removing age or diameter related long-term growth trends (Fritts, 1976; Schweingruber, 1983; Cook \& Kairiukštis, 1990), the detrend function that is incorporated in the dplR package (Bunn, 2008) of the statistical programming environment ' $R$ ', version 3.0.2 ( $R$ Development Core Team, 2013), was employed. From a set of three detrending techniques, the cubic smoothing spline method with a $50 \%$ frequency cutorf at twothird of the series length was selected. It turned out to be most appropriate for our data because individual tree mean curves did not exhibit a uniform trend and differed in length (cp. Weemstra et al., 2013). Standardization was carried out through division of the measured ring width by the expected growth rate (Fritts, 1976; Bunn, 2008), resulting in nondimensional 
$906 \mathrm{~J}$. METZ et al.

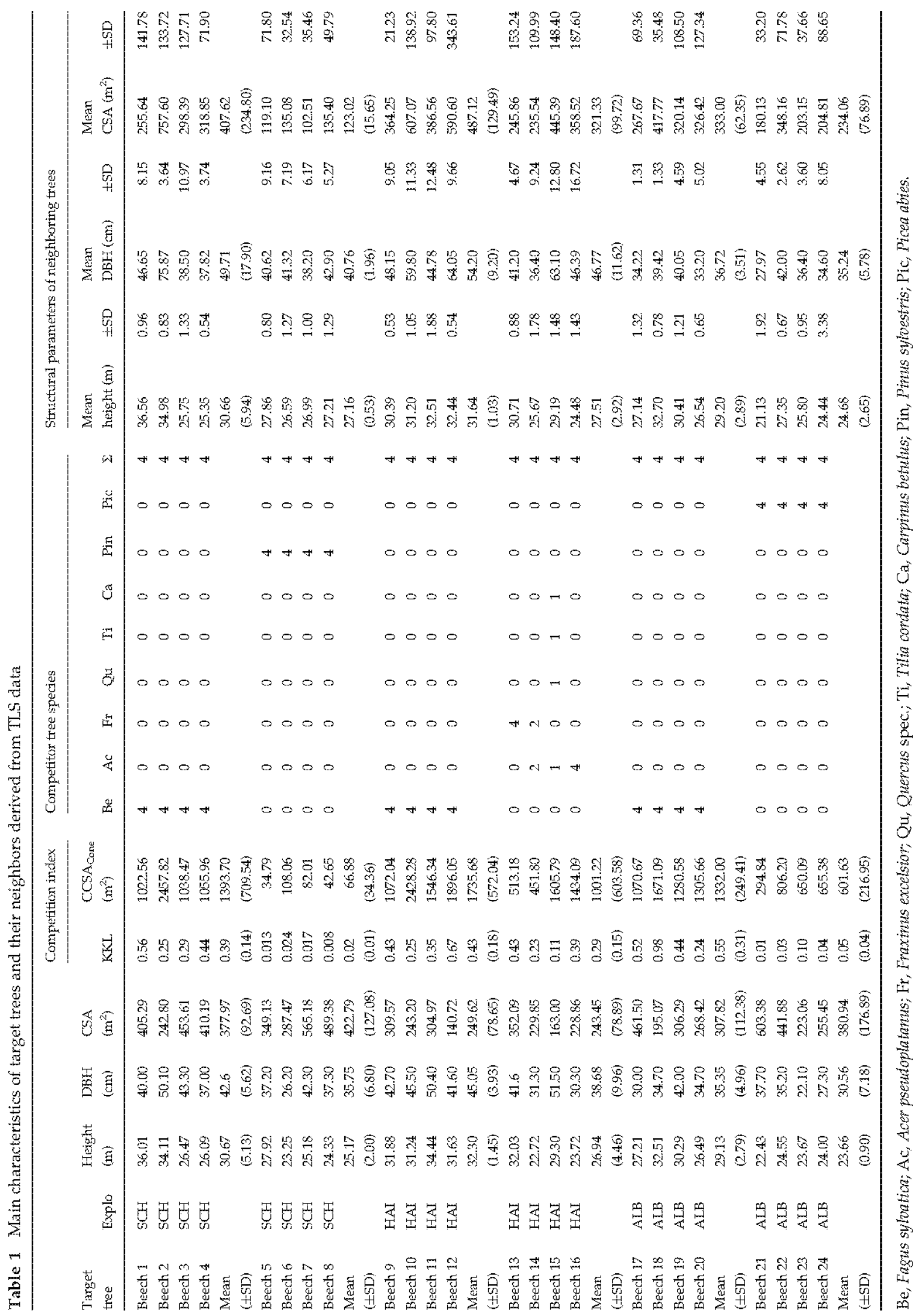




\section{MIXTURES IMPROVE WATER AVAILABILITY OF BEECH 907}

ring-width indices (RWIs). Using Tukey's biweight robust mean, standard chronologies were built (Bunn, 2008).

\section{Stable isotope measurements}

Upon completion of the ring-width measurements, tree rings of the 4-year periods 1975-1978 and 2002-2005 from increment cores of all 24 target trees were dissected separately with a scalpel under a Zeiss SR incident-light stereo microscope (8-50 $\times$ magnification). These periods include the low-precipitation pointer years 1976 and 2003 which were selected to analyze the wood $\delta^{13} \mathrm{C}$-signature of beech as a function of neighborhood tree species composition because the ${ }^{13} \mathrm{C} /{ }^{12} \mathrm{C}$ ratio of annual rings can be used as a measure for the past drought stress and intrinsic water-use efficiency of C3 plants (Farquhar et al., 1989; Duquesnay et al., 1998;). For the analysis of tree-ring carbon isotopic composition, from the two cores of a target tree that one with the best cross-date result was used. After drying the sample material at $50^{\circ} \mathrm{C}$, the complete tree rings (cp. Hemming et al., 1998) were milled in a Retsch MM2 pulverizer (RETSCH, Haan, Germany). Homogenization is recommended to avoid above-average proportions of individual parts of the ring in the weighted sample (Borella et al., 1998). We refrained from performing a cellulose extraction (cp. Geßler et al., 2001) because for tree species such as beech or oak, $\delta^{13} \mathrm{C}$ determined from wood was found to be an equivalent proxy for climate compared to cellulose (Borella et al., 1998). The material of each tree was measured discretely instead of pooling wood from different specimen (Liu et al., 2012). As the inclusion of nationwide dry years leads to a high probability for strongly deviating growth patterns of single trees within the sample set, we complied with the recommendation of Borella $e_{t}^{t}$ al. (1998) to analyze all trees individually during periods with considerable differences in individual tree growth. Approximate $1 \mathrm{mg}$ of the dried and homogenized wood powder of every tree ring was filled into tin capsules. $\delta^{13} \mathrm{C}$-signature was measured using an isotope ratio mass spectrometer (Finnigan MAT Delta plus, Bremen/Germany) that is connected with an NA2500 elemental analyzer (CE-Instruments, Rodano/Italy) by a ConFlo III interface (Thermo Electron Cooperation; Finnigan Advanced Mass Spectrometry, Bremen, Germany). Using acetanilide as internal chemical standard, $\delta^{13} \mathrm{C}$-values of the analyzed samples were calculated with the following equation and expressed in the Delta notation relative to the international substitute limestone standard denoted as Vienna Pee Dee Belemnite (VPDB):

$$
\delta^{13} \mathrm{C}(\%)=\left(\frac{\left[R_{\text {Sample }}\right]}{\left[R_{\text {Standard }}\right]}-1\right) \times 1000
$$

The approach proposed by McCarroll \& Loader (2004) has been adopted to correct the atmospheric decline in $\delta^{13} \mathrm{C}$ that is linked to industrialization by adding individual compensation factors for each year to the measured $\delta^{13} \mathrm{C}$ of every growth ring, hereinafter denoted as $\delta^{13} \mathrm{C}_{\text {corr }}$ ( $c$ p. Mölder et al, 2011; Härdtle et al, 2013). Furthermore, to reveal universal trends in ${ }^{13} \mathrm{C} /{ }^{12} \mathrm{C}$ ratios of tree rings during periods that comprise nationwide dry years, the normalization procedure presented from Bukata \& Kyser (2008) was employed, so that $\delta^{13} \mathrm{C}_{\text {corr }}$-data of each core were transformed in dimensionless index values ranging between 0 and 1 (cp. Härdtle $e t$ al., 2013).

\section{Climate data}

Representative for the three Biodiversity Exploratories

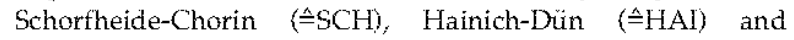

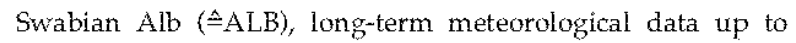
September 2011 from the weather stations Angermünde/ SCH $\left(53.02^{\circ} \mathrm{N} ; 14.00^{\circ} \mathrm{E} ; 54 \mathrm{~m}\right.$ a.s.l), Leinefelde/HAI $\left(51.24^{\circ} \mathrm{N}\right.$; $10.19^{\circ} \mathrm{E}$; $356 \mathrm{~m}$ a.s.l) as well as Münsingen-Apfelstetten/ALB $\left(48.23^{\circ} \mathrm{N} ; 09.29^{\circ} \mathrm{E} ; 750 \mathrm{~m}\right.$ a.s.l) were provided from the German National Meteorological Service 'DWD' (Deutscher Wetterdienst 2013).

\section{Statistical analysis}

Statistical properties of raw and detrended chronologies were likewise calculated using the package dplR (Bunn, 2008). Two important statistical parameters that can be computed from ring-width chronologies are mean sensitivity and first-order autocorrelation (AC1). Mean sensitivity is commonly considered as an indicator for the dependency of radial increment from external influencing factors such as climate (Dittmar et al, 2003; Beck, 2007, 2011; Weber et al., 2013) as it quantifies the amount of relative variability in width of successive tree rings (Fritts, 1976). First-order autocorrelation accounts for the relationship between current year's ring width and tree growth of the previous year (Fritts, 1976; Beck, 2007, 2011).

Following other studies that analyzed the impact of dry years on stem increment of different species (e.g. Fekedulegn et al., 2003; DeClerck et al., 2006; Martín-Benito et al., 2008; Kohler et al., 2010; Lloret et al., 2011; Zang et al., 2012; Pretzsch et al, 2013), single tree-based indices were calculated to quantify the degree of water stress-induced growth depression, respectively, postdrought recovery of annual increment. If such measures are created on the basis of RWIs, they are not susceptible to naturally induced differences in individual tree dimensions (Fekedulegn et ill., 2003). Therefore, ratios between standardized ring-width data of the drought year under investigation and corresponding pre- or postdrought periods were computed according to the equations below:

$$
\begin{aligned}
& \text { Resistance }\left(R_{l}\right)=\frac{\text { RWI }_{\text {DryYear }}}{\text { Mean } \text { RWI }_{I_{s} P_{\text {reDryy }} \text { Years }}} \\
& \text { Recovery }\left(R_{\mathrm{v}}\right)=\frac{\mathrm{RWI}_{\text {PostDryYear }}}{\text { RWI }_{\text {Dry Year }}} \\
& \text { Resilience }\left(R_{s}\right)=\frac{\text { RWI }_{\text {FostDryYaar }}}{\text { MeanRWI }}
\end{aligned}
$$

The impact of water limitation on the stable isotope signature of beeches being exposed to either intra- or interspecific competition was also quantified separately for each Exploratory. We calculated the mean quotient of $\delta^{13} \mathrm{C}$-values from pre-drought, respectively, postdrought and dry years (cp. axis titles in Fig. 7 and 8 or Zang et al, 2012), which is considered 
to be a measture for water stress. To check whether mean ratios of RWIs and $\delta^{13} \mathrm{C}$-values for drought and postdrought years significantly differ from 1 , one-sample t-tests were conducted (cp. Zang et al, 2012) on the level of competitor tree species groups. Thereby, resistance indices $\left(R_{t}\right)<1$ indicate a growth decline during drought and an $R_{c}$ index $>1$ attests recovery of stem increment in the following year. As water stress causes an increase of ${ }^{13} \mathrm{C} /{ }^{12} \mathrm{C}$ ratios, the $\delta^{13} \mathrm{C}$-index behaves vice versa. If resilience $\left(R_{s}\right)$ reaches an index $\geq 1$, increment during the postdrought vegetation period (out-) matched the predrought benchmark. For the years $1975-1978$ and 2002-2005, pair-wise comparisons of annual mean tree-ring widths as well as $\delta^{13} \mathrm{C}$ values between focal beeches from pure and mixed stands of the same Exploratory were conducted with the function npar.t.test from the package 'nparcomp' of ' $\mathrm{R}$ '. It performs two sample tests for the nonparametric Behrens-Fisher problem and can be applied on small sample sizes as a studentized permutation test is implemented (Brunner \& Munzel, 2000; Neubert \&: Brunner, 2007). The same statistical method was used to test whether average index values for drought-related growth depression, recovery as well as resilience and $\delta^{13} \mathrm{C}$ increase or decrease differ significantly as a function of neighborhood diversity within an Exploratory. Differences in mean ring widths between raw site chronologies calculated for the period 1970-2011 were evaluated with the nonparametric Tukey multiple comparison test that is based on relative contrast effects (package 'nparcomp'). Significance level was $p<0.05$ in all tests. Multiple linear regression was used to test the relationship between current competition (quantified by the competition index CCSA Cone ) and wood stable isotope ratios ( $x$ for the period 2002-2005). Beside competition intensity, site (represented by the Exploratory coded as orthogonal contrasted dummy variable) and 2003 basal area of the target trees were used as regressors while $\delta^{13} \mathrm{C}$ was the response variable. Outliers were identified by analyzing studentized residuals according to Fahrmeir et al. (2009). All calculations and statistical analyses were performed by using ' $R$ ' ( $R$ Development Core Team, 2013).

\section{Results}

\section{Climate data}

For the period 1970-2011, linear regression analysis revealed a significant increase of mean temperature during the growing season for all three study areas by $1.7-2.0^{\circ} \mathrm{C}\left(\mathrm{SCH}:+1.7^{\circ} \mathrm{C}, R_{\text {adj }}^{2}=0.38, P<0.001\right.$, $y=0.041 x+13.62, x=$ year; HAI: $+1.9^{\circ} \mathrm{C}, R_{\text {adj }}^{2}=0.42$, $P<0.001, y=0.046 x+12.30, x=$ year; ALB: $+2.0^{\circ} \mathrm{C}$ $R_{\text {adj }}^{2}=0.45, \quad P<0.001, y=0.048 x+11.44, x=$ year $)$, whereas precipitation records for the same phase did not exhibit a statistically corroborated decline. The years 1976 and 2003 stand out not only due to very low amounts of precipitation during the growing season but the negative impact of water scarcity on tree growth has regionally been exacerbated by above-average temperatures at the same time (Fig. S2).

\section{Long-term tree-ring widths and chronology statistics as a function of neighborhood identity}

Compared to the mean time series that were calculated from target trees being exposed to interspecific competition, within all Exploratories, average ring widths of raw site chronologies from beeches growing in pure stands were consistently smaller (Table 2). However, the difference between mean annual growth rates from monocultures and mixed stands of the same region was statistically significant only in the Schorfheide-Chorin area (Table 2, Fig, 1). First-order autocorrelation corresponding to the 41-year period of interest ranged between 0.30 and 0.40 except for the mean time series representing the target trees from the Exploratory Schorfheide-Chorin whose competitors exclusively consist of Scots pines (Table 2). In this case, the negative correlation coefficient of -0.249 results from strongly fluctuating ring widths of consecutive years. In contrast, positive autocorrelation is an expression of persistence, meaning that year-to-year ring-width differences are less severe. Irrespective of the competitor tree species, mean sensitivity of all types of beech chronologies increased with decreasing precipitation (Table 2). Consequently, lowest mean sensitivity was observed at the Swabian Alb sites, followed by the Exploratories Hainich-Dün and Schorfheide-Chorin. Internal comparisons indicated that species identity of the competing neighbors possibly affected mean sensitivity, as interspecific interference resulted in slightly lower sensitivities (Table 2).

\section{Drought-induced reactions of radial beech growth as a function of neighborhood identity}

With exception of beeches from pure stands of the Exploratory Schorfheide-Chorin, standardized target tree growth declined significantly in at least one of the two dry years at all study regions (Figs $2 \mathrm{a}$ and $3 \mathrm{a}$ ). Resistance $\left(R_{t}\right)$ of beeches in pure stands tended to be higher than that of the target trees from the same Exploratory whose competitors belonged to other species (Figs $2 \mathrm{a}$ and $3 \mathrm{a}$ ). Pair-wise comparisons showed that target tree growth decline differed significantly only between beeches in pure and mixed stands of the Exploratory Swabian Alb during the year 2003 (Fig. 3a). Regardless of the competitor tree species, resistance of the beech trees from the Schorfheide-Chorin area was nearly the same in both drought periods (Figs $2 \mathrm{a}$ and 3a). In the two other regions, when compared to 1976 , relative growth decline in 2003 had been less severe during the dry year and fell significantly below predrought level only in groups with interspecific competition (Figs $2 \mathrm{a}$ and $3 \mathrm{a}$ ). 
MIXTURES IMPROVE WATER AVAILABILITY OF BEECH 909

Table 2 Statistical parameters of raw (RAW) and standard (STD) chronologies from the three different study areas for the period 1970-2011. Asterisks label a significant difference between mean ring widths of raw site chronologies from pure and mixed stands within the same Exploratory (package 'nparcomp' $P<0.05$ )

\begin{tabular}{|c|c|c|c|c|c|c|}
\hline \multirow{2}{*}{$\begin{array}{l}\text { Chronology type } \\
\text { Competitor species }\end{array}$} & $\mathrm{HAI}_{\text {RAW }}$ & $\mathrm{HAI}_{\mathrm{STD}}$ & $\mathrm{SCH}_{\mathrm{RAW}}$ & $\mathrm{SCH}_{\mathrm{STD}}$ & $\mathrm{ALB}_{\mathrm{RAW}}$ & $\mathrm{ALB}_{\mathrm{STD}}$ \\
\hline & \multicolumn{2}{|c|}{ European beech } & \multicolumn{2}{|c|}{ European beech } & \multicolumn{2}{|c|}{ European beech } \\
\hline Mean ring width $(\mathrm{mm})$ & 1.862 & 0.996 & $1.573^{*}$ & 0.941 & 2.33 & 1.015 \\
\hline Standard deviation & 0.495 & 0.216 & 0.535 & 0.299 & 0.498 & 0.195 \\
\hline Mean sensitivity I & 0.252 & 0.249 & 0.303 & 0.301 & 0.183 & 0.202 \\
\hline First-order autocorr. & 0.309 & -0.069 & 0.306 & 0.014 & 0.358 & 0.192 \\
\hline Competitor species & \multicolumn{2}{|c|}{ Valuable hardwoods } & \multicolumn{2}{|c|}{ Scots pine } & \multicolumn{2}{|c|}{ Norway spruce } \\
\hline Mean ring width $(\mathrm{mm})$ & 2.002 & 0.999 & $3.257^{*}$ & 1.006 & 2.463 & 1.01 \\
\hline Standard deviation & 0.55 & 0.22 & 0.75 & 0.216 & 0.529 & 0.16 \\
\hline Mean sensitivity I & 0.228 & 0.233 & 0.28 & 0.274 & 0.179 & 0.178 \\
\hline First-order autocorr. & 0.403 & 0.059 & -0.249 & -0.403 & 0.332 & -0.066 \\
\hline
\end{tabular}

${ }^{*}$ significance level of 0.05 .
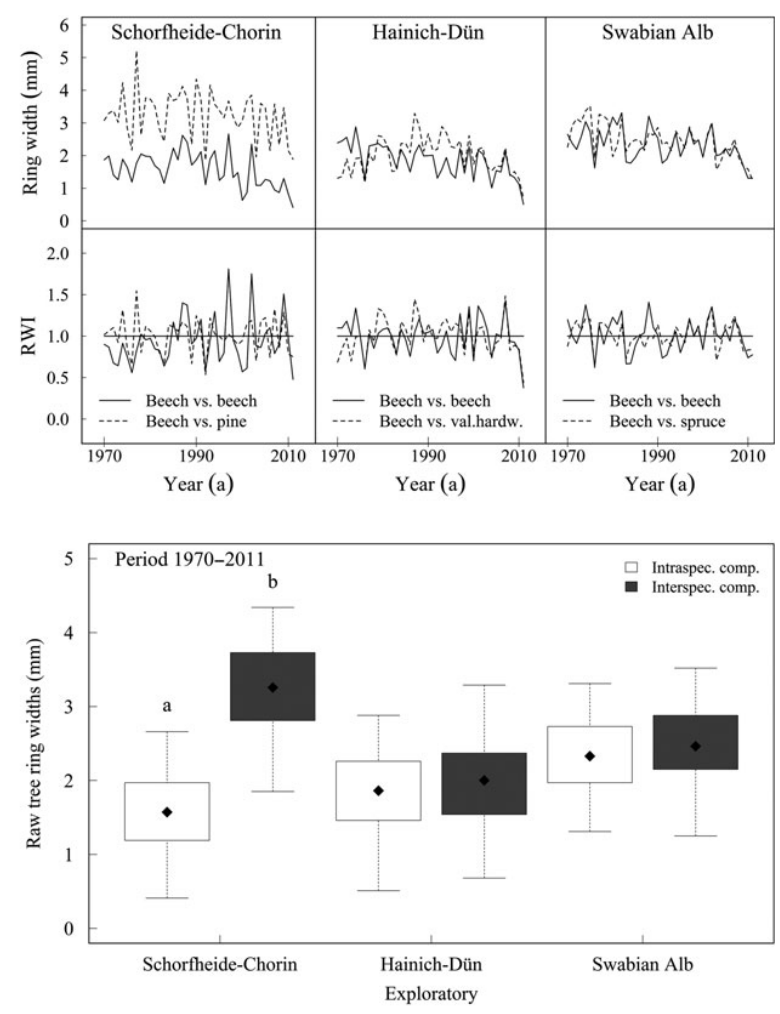

Fig. 1 Raw and standardized site chronologies (top) as well as average ring-widths of mean time series (bottom) calculated from target tree beeches being exposed to either intra- or interspecific competition. Different letters above the box-whiskerplots indicate significant differences between mean ring widths of raw site chronologies within the same Exploratory (nonparametric Tukey multiple comparison test: $P<0.05$ ).

In contrast to resistance, average growth recovery $\left(R_{c}\right)$ of the beeches exposed to interspecific competition was invariably higher than that of the target trees growing in pure stands of the same region. However, pair-wise tests did not reach significance (Figs $2 b$ and $3 b$ ) and the differences within the Exploratories HAI and ALB were marginal in 1977. In 2004, recovery $\left(R_{c}\right)$ was lower compared to 1977 due to the enduring, respectively, proceeding growth decline which was most evident at the Hainich-Dün and Swabian Alb sites (Figs $2 b$ and $3 b$ ).

Apart from the Swabian Alb sites, mean $R_{s}$-values calculated from target trees growing in monospecific neighborhoods were (insignificantly) lower during both periods under review (Figs 2c and 3c). In 2004, only target tree beeches with Scots pines as competitor trees reached the average predrought increment rate $\left(R_{s} \geq 1\right)$, whereas in 1977, all standard chronologies came close to or surpassed the reference growth level (Figs 2c and 3c).

Actual mean ring-widths and $\delta^{13} C$-signatures during periods comprising drought years as a function of neighborhood identity

During the 4-year episodes under investigation, actual mean ring widths (in $\mathrm{mm}$ ) of beeches that were exposed to interspecific competition exceeded the mean values of target trees from pure stands of the same region in the majority of comparisons (Figs 4 and 5). The exceptions were beeches in the neighborhood of valuable hardwoods (HAI) during both periods and target trees surrounded by Norway spruce (ALB) in the period around 2003 (Figs 4 and 5). However, significant differences were only found between mean ring widths of target trees exclusively surrounded by beech or Scots pine at the Schorfheide-Chorin area (Figs 4 and 5). Compared to 1977, mean annual ring widths were generally smaller in 2004 across all sites and neighborhoods. 
910 J. METZ et al.

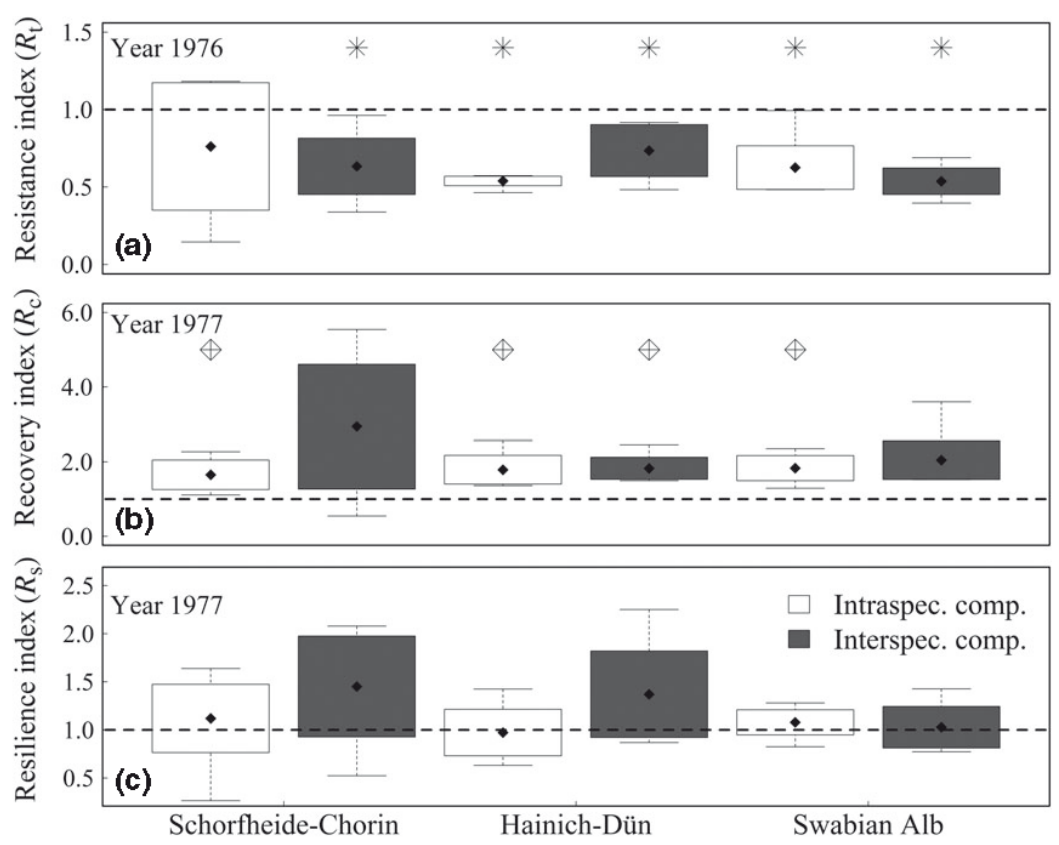

Fig. 2 (a) Drought resistance of target beeches in groups of intra- or interspecific competition during the dry year 1976. (b) Radial growth recovery of target beeches in groups of intra- or interspecific competition during the postdrought year 1977 (c) comparison between post- and predrought growth levels ( $\hat{=}$ resilience) of target beeches in groups of intra- or interspecific competition. Asterisks label a significant growth decline and thombi a full recovery in the postdrought year as mean index ratios significantly differ from 1 (one-sample $t$ test: $P \leq 0.05$ ).

As indicated by predominantly lower $\delta^{13} \mathrm{C}$-values, beech trees growing under interspecific competition were exposed to lower water stress throughout both periods (Figs 4 and 5). As a result, ring widths and $\delta^{13} \mathrm{C}$-values of most trees were highly negatively correlated (Table S1). However, trees differ in their responses even within a given site and neighborhood. This variance is explained by the close relationship between competition intensity and $\delta^{13} \mathrm{C}$ (Fig. 6). The observed relationship indicates that the neighborhood identity effect is mainly an effect of competition pressure. The more the trees are exposed to competition, the higher the $\delta^{13} \mathrm{C}$-value is (Fig. 6). In contrast to competition, neither site (Exploratory) nor tree basal area contributed to explain the variation of $\delta^{13} \mathrm{C}$-values.

\section{Period 1975-1978}

During summer 1976, target beech trees at the Exploratories Hainich-Dün and Swabian Alb were exposed to more intense water stress irrespective of their competitive neighborhood as indicated by the significantly increased wood $\delta^{13} \mathrm{C}$ signatures (Figs 4 and 7a). This is confirmed by the fact that the belonging normalized $\delta^{13} \mathrm{C}$-values ( $\delta^{13} \mathrm{C}_{\text {corrnorm. }}$ ) took a value of one revealing no intra-annual variation concerning the common temporal trend of all trees (Fig. 4). In the
Exploratory Schorfheide-Chorin, the summer drought of 1976 had no significant impact on the $\delta^{13} \mathrm{C}$ records (Figs 4 and 7a). However, at all sites, mean $\delta^{13} \mathrm{C}_{\text {corr }}$-values of beeches growing in mixtures with co-occurring species were almost invariably lower than those of trees growing in pure stands, suggesting an improved water availability (Fig. 4). Only at the Exploratories Swabian Alb and Schorfheide-Chorin, the nonparametric two sample tests indicated significant differences between the mean $\delta^{13} \mathrm{C}_{\mathrm{corr}}$-values of target trees from monocultures and mixtures. In contrast to 2003 (see below), the impact of the precipitation deficit was restricted to the dry year. The stable isotope ratios of the subsequent years suggest a rapid normalization of the water balance (Figs 4 and $7 \mathrm{~b}$ ). These findings are consistent with the results of the ring-width measurements during this phase (Fig. 4).

\section{Period 2002-2005}

As for the period 1975-1978, the mean $\delta^{13} \mathrm{C}$-values of beeches with conspecific neighborhoods were almost always higher than under interspecific competition indicating more intense water stress of target trees from pure stands again, even if the difference in mean stable isotope ratios between beeches in pure and mixed stands was significant only in the predrought year 2002 


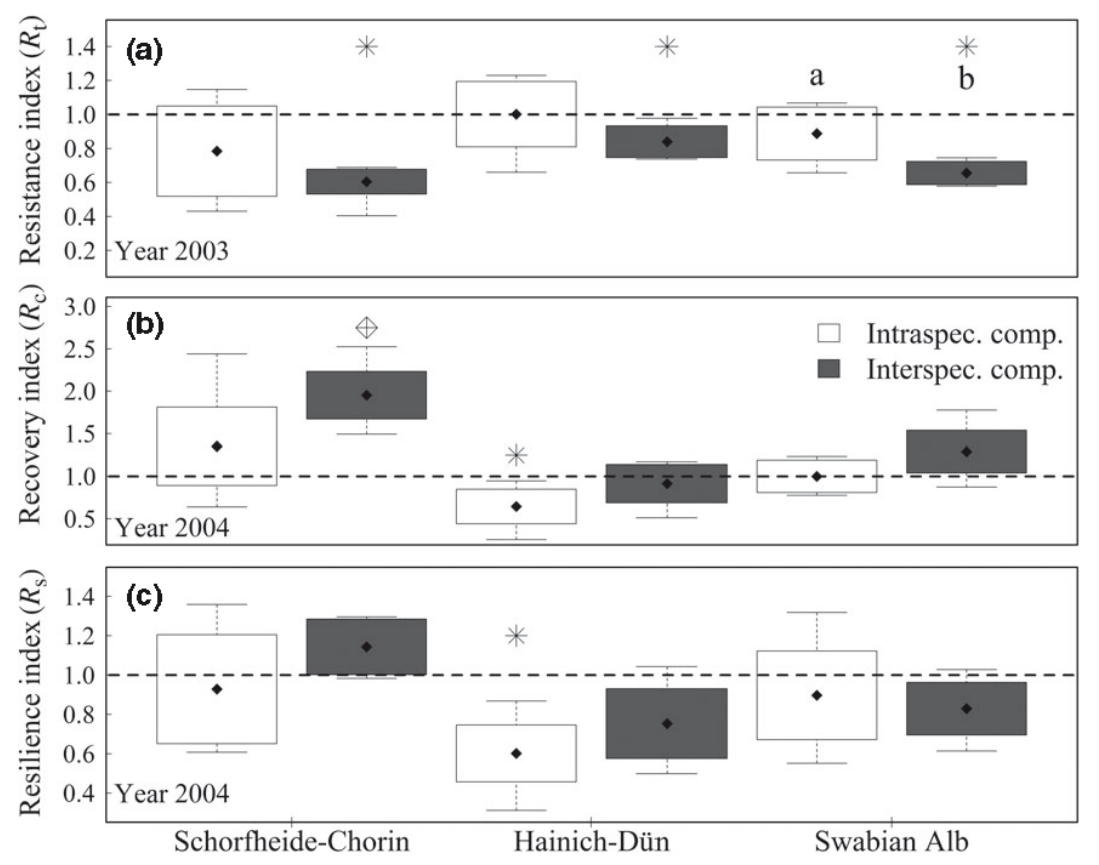

Fig. 3 (a) Drought resistance of target beeches in groups of intra- or interspecific competition during the dry year 2003. (b) Radial growth recovery of target beeches in groups of intra- or interspecific competition during the postdrought year 2004. (c) Comparison between post- and predrought growth levels ( $\hat{=}$ resilience) of target beeches in groups of intra- or interspecific competition. Asterisks label a significant growth decline and rhombi a full recovery in the postdrought year as mean index ratios significantly differ from 1 (one-sample $t$ test: $P \leq 0.05$ ). Superscript letters above the box-whisker-plots indicate significant differences between target trees of the same Exploratory that are exposed to either intra- or interspecific competition (npar.t.test: $P \leq 0.05$ ).

at the Exploratory Schorfheide-Chorin (Fig. 5). After 2003, general trends in the ${ }^{13} \mathrm{C} /{ }^{12} \mathrm{C}$ ratios decreased irrespective of the investigated competitive situation but especially beech trees at the Schorfheide-Chorin area showed the typical pattern in terms of less negative ${ }^{13} \mathrm{C} /{ }^{12} \mathrm{C}$ ratios as a consequence of the precipitation deficit in 2003, but constantly and equally decreasing drought stress in the years immediately after water shortage (Figs 5 and 8). Therefore, not in every case, the average 2005 wood carbon isotopic composition of target trees had reached the predrought level.

At the Schorfheide-Chorin site, water stress-induced increase in $\delta^{13} \mathrm{C}$ and postdrought recovery of isotope ratios were significant only in target trees exposed to interspecific competition (Fig. 8a, b). This result and the finding that all ${ }^{13} \mathrm{C} /{ }^{12} \mathrm{C}$ ratios from beech trees exclusively surrounded by Scots pine reached their maximum value in the dry year itself (normalized $\delta^{13} \mathrm{C}$ value of 1), indicate a stronger relative increase of water stress compared to intraspecific competition processes in pure stands of the same region.

At the Exploratory Hainich-Dün, stable isotope signatures exhibited a uniform increase (normalized $\delta^{13} \mathrm{C}$ values of 1 and 0.84 ) due to the 2003 rainfall deficit resulting in maximum wood $\delta^{13} \mathrm{C}$-values regardless of the competitor tree species (Fig. 5). Nevertheless, the drought-induced change in the isotopic composition was statistically significant only in tree rings of beeches from pure stands (Fig. 8a). In the postdrought years, $\delta^{13} \mathrm{C}$-trends diverged depending on the diversity of the competitive neighborhood.

Wood of target beech trees from the Swabian $\mathrm{Alb}$ formed in 2003 was significantly less depleted in ${ }^{13} \mathrm{C}$ (Fig. 8a). However, in contrast to the other regions, the isotope ratios from this Exploratory were almost at the same level during first 2 years of the period 2002-2005 irrespective of the neighborhood identity (Fig. 5). In $2004, \delta^{13} \mathrm{C}$-values in tree rings from pure beech stands closely matched the isotope signature of the preceding drought year, whereas in mixture with Norway spruce, the trend of decreasing $\delta^{13} \mathrm{C}$ in wood started the first year after drought but did not yield statistical significance in Figs 5 and $8 b$.

\section{Discussion}

\section{Methodical considerations}

As in other studies, combining dendrochronological and dendrochemical techniques resulted in small 
912 J. METZ et al.

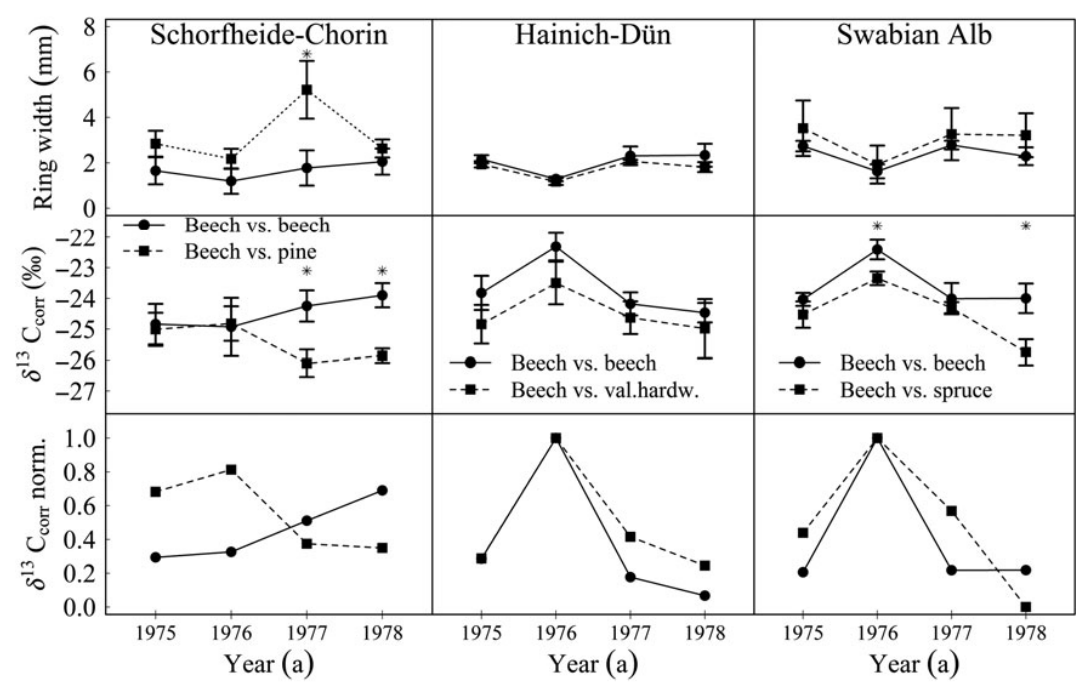

Fig. 4 Ring-widths as well as corrected (yearly averages $\pm 1 \mathrm{SE}$ ) and normalized $\delta^{13} \mathrm{C}$-signatures of target trees in groups of intra- or interspecific competition during the 4-year periods 1975-1978. Asterisks label significant differences between annual means of beeches from pure and mixed stands of the same Exploratory (npar.t.test: $P \leq 0.05$ ).

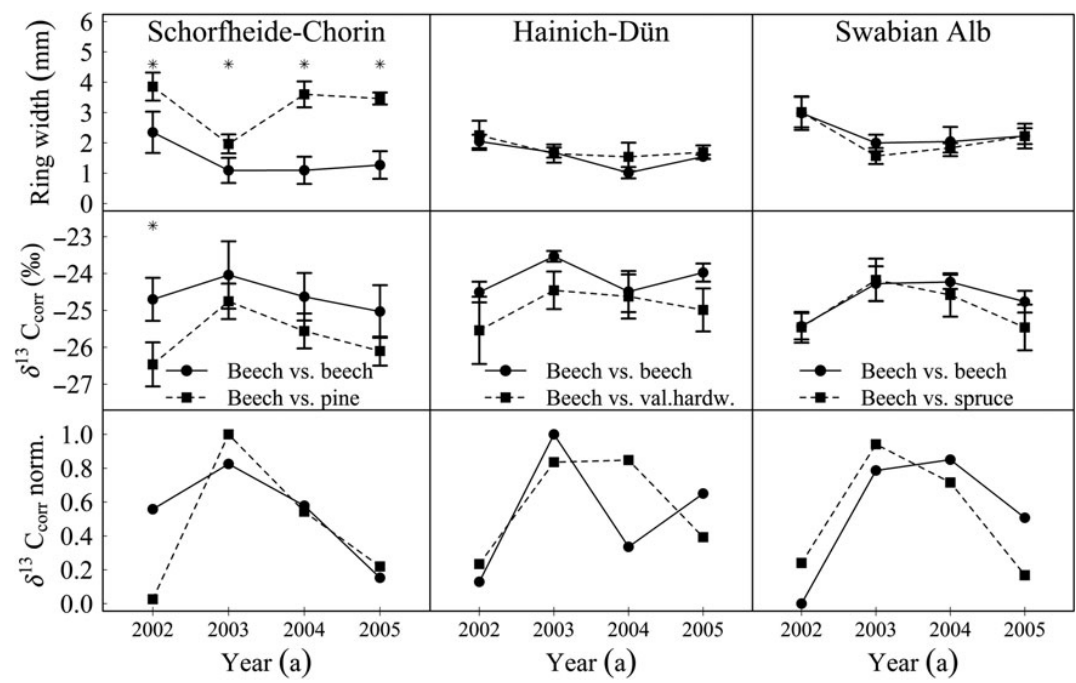

Fig. 5 Ring-widths as well as corrected (yearly averages $\pm 1 \mathrm{SE}$ ) and normalized $\delta^{13} \mathrm{C}$-signatures of target trees in groups of intra- or interspecific competition during the 4-year periods 2002-2005. Asterisks label significant differences between annual means of beeches from pure and mixed stands of the same Exploratory (npar.t.test: $P \leq 0.05$ ).

sample sizes (cp. Mölder et al., 2011). This implies that statistical evidence was partly difficult to provide. However, the common environmental signal in treering stable isotope ratios is more homogenous than that derived from ring-width series (Robertson et al., 1997; McCarroll \& Loader, 2004). As a consequence, $4-5$ trees are sufficient to compile an adequate selection for correlation with climatic parameters (McCarroll \& Loader, 2004) what can be transferred to the focus of our study. Unfortunately, the small sample size, the availability of only one mixture type per site, the nonavailability of continuous competition measures that quantify the crown competition the target trees were exposed to at the beginning of the observation period, and the confounding impact of deviating target tree dbh between the investigation areas did not allow data analysis across the Exploratories. However, the site-by-site comparisons of inter- and intraspecific competition revealed interesting insights into the effect of locally adapted admixed species that are frequently cultivated $(\mathrm{SCH}$ : 


\section{MIXTURES IMPROVE WATER AVAILABILITY OF BEECH 913}

Scots pine; HAI: sycamore maple and European ash; ALB: Norway spruce) on growth performance and physiological adaption of target beech trees in the given growing regions.

Long-term tree-ring widths and chronology statistics as a function of neighborhood identity

In our first hypothesis, we stated that within the same Exploratory, mean ring width of European beech trees is higher when exposed to inter- than to intraspecific competition over a period of four decades. Though

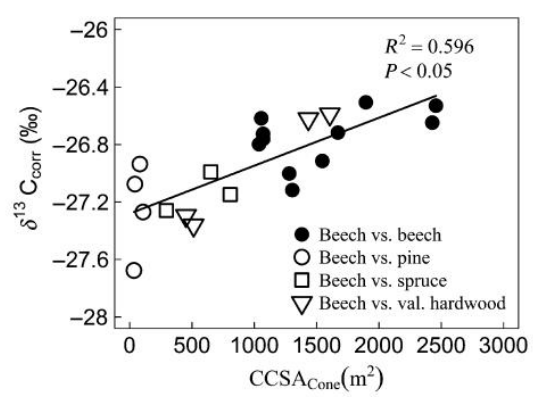

Fig. 6 Relationship between wood stable isotope ratios ( $\bar{x}$ for the period 2002-2005) as a measure for water stress and competitive pressure $\left(\mathrm{CCSA}_{\mathrm{Cone}}\right)$ enforced to target tree beeches in intra- or interspecific neighborhoods. significant only for beech surrounded by Sots pine the general trend suggests to accept the hypothesis (Fig. 1; Table 2). Growth limitation due to interspecific competition by Pinus was found to be less pronounced than in pure beech forests (cp. Milios, 2004; Condés et al., 2013) as the crowns of the shade intolerant Scots pine are smaller, transmit more light (Pacala et al., 1996; Pretzsch, 2001) and intercept less water than beech crowns do. Furthermore, Curt \& Prévosto (2003) found fine-root biomass of mature beech trees to be considerably higher than that of Scots pine in all soil depths, leading to the conclusion that root development of beech is highly adaptable and competitive in mixture with this conifer species. However, this competitive advantage cannot fully compensate lower field capacities or frequent lacks of precipitation during the growing seasons at the Exploratory SchorfheideChorin. Therefore, beech in the mixed stands of this region is likewise affected by these adverse site factors. This may have caused the strong interannual variability in radial increment (negative AC1-values) of target trees being surrounded by Scots pine.

At the two other sites HAI and ALB, the trend toward a higher diameter growth of the trees surrounded by other species than beech was also measurable but not significant (Fig. 1). Depending on the competitive neighborhood, the findings of our research may have various causes: In mixtures of Fagus sylvatica
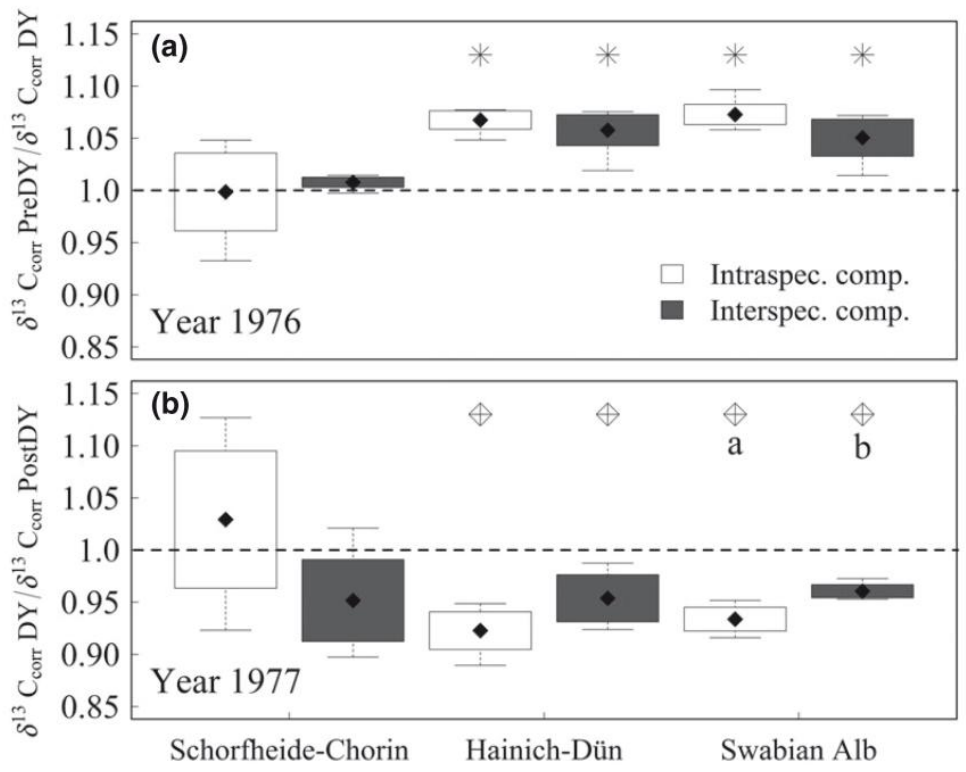

Fig. 7 (a) relative $\delta^{13} \mathrm{C}$ increase due to the 1976 precipitation deficit calculated as the quotient of tree-ring $\delta^{13} \mathrm{C}$-values from the predrought and drought year. (b) Relative $\delta^{13} \mathrm{C}$ decrease in 1977 calculated as the quotient of tree-ring $\delta^{13} \mathrm{C}$-values from the drought and postdrought year. Asterisks and rhombi label a significant $\delta^{13} \mathrm{C}$ increase, respectively, decrease as mean index ratios differ significantly from 1 (one-sample $t$ test: $P \leq 0.05$ ). Superscript letters above box-whisker-plots indicate significant differences between target trees of the same Exploratory that are exposed to either intra-or interspecific competition (npar.t.test: $P \leq 0.05$ ). 
914 J. METZ et al.
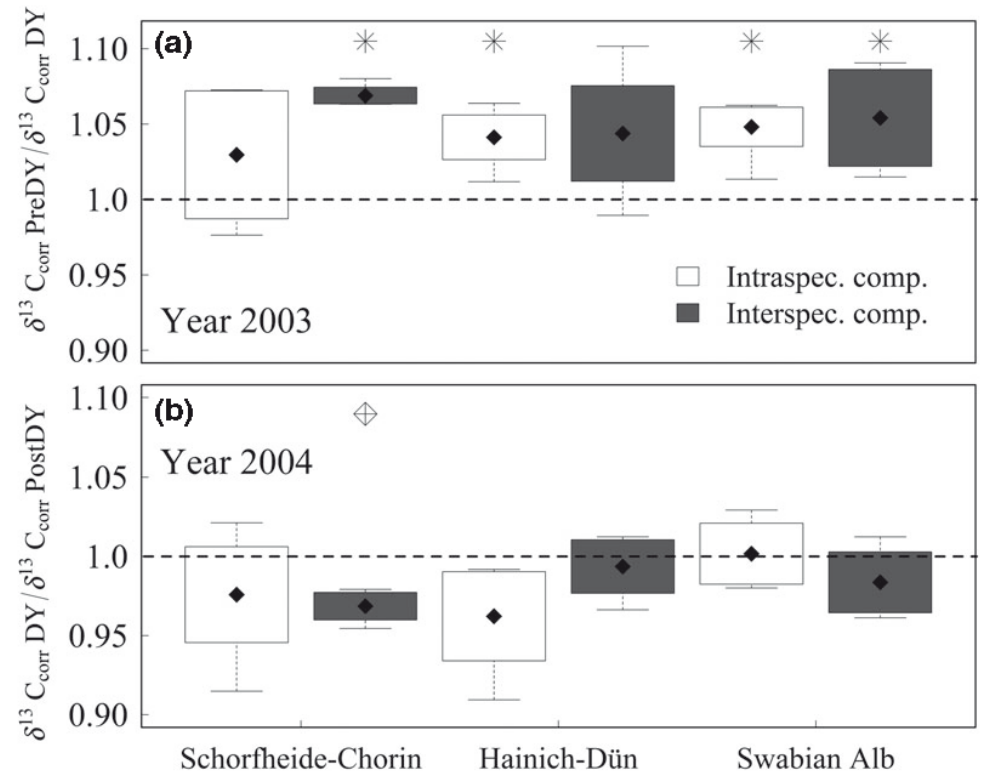

Fig. 8 (a) relative $\delta^{13} \mathrm{C}$ increase due to the 2003 precipitation deficit calculated as the quotient of tree-ring $\delta^{13} \mathrm{C}$-values from the predrought and drought year (b) relative $\delta^{13} \mathrm{C}$ decrease in 2004 calculated as the quotient of tree-ring $\delta^{13} \mathrm{C}$-values from the drought and postdrought year. Asterisks and thombi label a significant $\delta^{13} \mathrm{C}$ increase respectively decrease as mean index ratios differ significantly from 1 (one-sample $t$ test: $P \leq 0.05$ ).

and valuable hardwoods such as ash or sycamore maple, co-occurring species may not be different enough from beech in terms of basic plant traits that determine their competitive strength. In addition to equal stress reaction pattern, comparable crown architecture, foliage development, respectively, biomass or extent of root space are thought to be the main reasons for similar competition levels as well as yields in pure and mixed stands (Kelty \& Cameron, 1995; Kelty, 2006; Pretzsch et al., 2013). Hence, at the Hainich-Dün region, aboveground competition emanating from valuable hardwoods on beech was assessed to be only slightly lower than in pure stands (Table 1). Furthermore, target beech trees surrounded by valuable hardwoods had the smallest mean crown surface area (Table 1, Fig. S3), indicating a smaller photosynthetic active leaf area. Apparently, the mixture effect is the higher, the more different tree species traits are. This interpretation is supported by recent findings from analyzing the drought sensitivity of Abies alba, a conifer species. It was shown that this species responded much less to drought when growing in mixture with beech compared to mixtures with Norway spruce (Lebourgeois et al., 2013). These results do also support the validity of our second hypothesis indicating that mixtures may not only improve drought resistance and recovery of beech but also of other species known as less sensitive to drought.
Another reason for the weaker response in growth to competition from valuable hardwoods might be that the spatial rooting patterns of beech and competing valuable hardwoods were found to be very similar (Meinen et al., 2009; Jacob et al., 2013). In species rich neighborhoods, the percentage contribution of beech to stand fine-root biomass was found to be disproportionately low compared to its share in total stand basal area (Meinen et al., 2009).

In mixed stands with Norway spruce, Fagus sylvatica should be able to benefit from its ability to efficiently explore more drought resistant subsoil layers leading to a partial stratification of fine-root systems (Schmid, 2002; Bolte \& Villanueva, 2006; Bolte et al., 2013). However, the positive effect of Norway spruce neighborhoods on beech growth was quite weak. This finding supports the conclusion of Pretzsch et al. (2013) that it is not possible to explain stress reaction pattern of different mixtures exclusively with their competitive complementarity or deviating water stress prevention strategies (see also Jucker et al., 2014). The stressgradient hypothesis suggests that the magnitude of net facilitation by other species depends on the level of resource stress (Maestre et al., 2009). Based on this theory, no strong effect of Norway spruce on beech was expected. Indeed at the high-precipitation Swabian Alb sites, severe soil water stress only occurs during exceptional drought. Thus, the positive effect on the growth 
of beech in mixture with Norway spruce was most likely caused by the ability of beech to penetrate and occupy Norway spruce crown space with relative low biomass investment (Pretzsch \& Schütze, 2005, 2009).

\section{Mean sensitivity and first-order autocorrelation}

Interestingly, within the same Exploratory, cored beech trees exposed to interspecific competition tended not only to achieve higher mean radial increments but exhibited also lower mean sensitivity values than their conspecifics in nearby pure stands (Table 2). The latter might be interpreted as further evidence for improved resource availability in mixtures and hence reduced vulnerability of beech growth pattern to climatic conditions as a consequence of extenuated competitive stress. Moreover, the mean sensitivity values presented in Table 2 are influenced by site, revealing a decreasing climatic influence on radial increment along the precipitation and altitudinal gradient from the dry Schorfheide-Chorin area up to the low mountain range plots of the Swabian Alb with highest amounts of annual rainfall (cp. Dittmar \& Elling, 1999; Scharnweber et al., 2011). Highest climate sensitivities at the SchorfheideChorin area were accompanied by lowest first-order autocorrelations. Within Exploratories, target trees in the neighborhood of Scots pines stand out through a negative AC1-value of -0.249 demonstrating lacking buffer capacity and ability for persistence (Riemer, 1994; Beck, 2007, 2011). The competitive pressure at the Schorfheide area exerted by Scots pines seems to be negligible, so that in years with normal weather conditions, focal trees experience no water stress. Instead of accumulating carbohydrate reserves, these beeches achieved higher mean annual growth rates and formed bigger crown surface areas (Figs 1 and S3). However, in case of minor deviations from the normal precipitation regime, high growth rates could not be maintained (McDowell et al., 2006), resulting in strong interannual variations of ring widths (Fig, 1; Table 2). Carbohydrate storage of the target trees which promotes stem growth in spring (Skomarkova et al., 2006) is likely to be limited in case of strong intraspecific competition under the prevailing climatic and edaphic conditions, leading to narrow growth rings even in normal years. Hence, the interannual and weather-induced variability in ring-widths of target beech trees from pure stands of the Exploratory Schorfheide-Chorin was less pronounced than in mixture despite of the fact that individual tree competition was assessed to be stronger in monocultures. Martín-Benito et al. (2008) also assume that more intense competition, as long as it does not excessively vary over time, similarly controls radial increment in successive years. Consequently, differences in consecutive tree-ring widths may be more distinct if highly variable climate is the primary factor that controls annual growth instead of relatively constant intertree competition.

\section{Drought-induced reactions of radial beech growth as a function of neighborhood identity}

The second hypothesis was only partly confirmed by our results. With one exception, the resistance index $\left(R_{t}\right)$ suggested that within the same investigation area, the relative reduction of standardized radial increment caused by the drought years 1976 and 2003 was less severe in pure beech stands than the growth depression of target trees exposed to interspecific competition. But weaker relative growth depressions in pure beech stands were caused by predominantly narrower mean predrought ring widths of target tree beeches in monocultures (Figs 4 and 5). Furthermore, actual ring widths did not reveal a higher drought stress level under interspecific competition. Thus, because of converging year ring widths of beech growing in pure and mixed stands during exceptional dry years but differing predrought ring widths, resistance in monocultures was apparently higher than in the respective mixtures. This illustrates that it is necessary to consider relative and absolute growth rates, as any kind of percentage-based evaluation or standardization can cause a relevant loss of information, resulting in misinterpretations of actual increments.

We conclude that due to different morphological and functional properties in case of interspecific competition (Kelty, 2006), crown dimensions of the target trees (Fig. S3) as well as their assumed superiority in belowground resource acquisition might escalate. In the locally tested mixtures, this may have enabled them to derive greater benefit from moderate growth conditions with better water supply in nondrought years than in pure stands (McDowell ot al., 2006; Sohn et al., 2013). However, during drought, this advantage can turn into its opposite, because larger amounts of foliage or fine-root biomass may cause a higher need for water to cover their resource requirements (McDowell $e t$ al., 2006; D'A mato et al., 2013), leading to stronger relative growth depressions (cp. Sohn et al., 2013).

In contrast to resistance $\left(R_{t}\right)$, recovery $\left(R_{c}\right)$ of beech radial increment was, if compared within sites, higher in mixtures than in pure stands. With exception of the Exploratory Swabian Alb, the same applies to the resilience index $\left(R_{s}\right)$. This finding is supported by Mölder \& Leuschner (2014) who referred to comparable results from temperate broad-leaved forests. Thinning experiments in Norway spruce stands also showed that trees 
with more growing space, respectively, lower competitive stress due to heavy thinning recovered more rapidly than those just moderately or unthinned (Kohler et al., 2010; Sohn et al., 2013; Gebhardt et al., 2014). We assume that the positive effects of interspecific competition on growth, that was most distinct in the Schorfheide-Chorin area, but also on the $\delta^{13} \mathrm{C}$-values reflect the same mechanism: In the interspecific neighborhoods tested in our study, the likelihood of beech to be exposed to severe competition is much lower compared to intraspecific competition. Thus, release from competition, either through growing in the neighborhood of less competitive species or through the removal of conspecific competitors results in higher growth and less drought stress. Even if conducted in pure beech stands, other studies likewise infer that competition intensity determines climate and drought sensitivity of beech. Basal area growth of trees exposed to high competition was found to be more susceptible to summer heat and water limitation, whereas increment of beech trees classified as being subject to low competition was even positively influenced by warm temperatures (Piutti \& Cescatti, 1997; Cescatti \& Piutti, 1998). In view of global warming, the authors concluded that competitive pressure and thus the climatic response on individual tree as well as on stand level can be altered by silvicultural measures such as thinnings (Piutti \& Cescatti, 1997; Cescatti \& Piutti, 1998). Creating locally reasonable mixtures and thereby releasing beech from intraspecific competition (Kelty \& Cameron, 1995; Kelty, 2006; Pretzsch et al., 2012) seems to be another silvicultural option to reduce drought stress (Mölder \& Leuschner, 2014).

Although 1976 and 2003 were considered as exceptional dry years throughout Europe (Sohn et al., 2013), they differed in the time when water stress prevailed during the vegetation period (Mund et al., 2010). Consequently, the impacts on growth patterns appear to be different in both periods under investigation. Responding to the drought of 1976 which occurred already in early summer, target trees from all three Exploratories revealed a short-term growth decline regardless of neighborhood identity followed by a full recovery of average ring widths in the postdrought year (Fig. 2a, b). Therefore, water shortage must have occurred during the period from May to July, the phase with highest share of total annual girth increment in beech stands (Barbaroux \& Bréda, 2002; Bouriaud et al., 2004). Nevertheless, drought-induced restriction of photosynthesis and radial growth was limited to the 1976 vegetation period as proven by measurements of ring widths and stable isotope ratios (Figs 2, 4 and 7 ). The switchover from growth depression to immediate recovery in the first year after drought did not apply in equal measure to the summer drought in 2003 (Figs 3 and 5). In this year, all groups of target tree beeches formed on average smaller tree rings than in 2002, but at the Exploratories Swabian $\mathrm{Alb}$ and Hainich-Dün, resistance $\left(R_{t}\right)$ was more pronounced than in 1976. Only in the Schorfheide-Chorin area, 2003 ring widths and resistance indices $\left(R_{t}\right)$ were comparable to or even below the corresponding values of 1976, attesting that the drought-susceptible soils of this region were water depleted during the main growth period again. This is also confirmed by less negative $\delta^{13} \mathrm{C}$-values compared to the drought of 1976 (Figs 4 and 5 ). In contrast to the Schorfheide-Chorin region, at the other investigation areas, stem increment began earlier in 2003 (cp. Kahle, 2006; van der Maaten, 2013) and main growth had already terminated before relative plant-available soil water fell below the $60 \%$ threshold where secondary thickening starts to decline (Bogeat-Triboulot et al., 2007; Mund et al., 2010). This might have prevented more severe growth depressions and explains lower wood stable isotope ratios than in 1976. On the other hand, water stress during late summer diminishes carbon storage at the end of the growing season what might have caused a late or weak onset of wood formation in 2004 (Bréda et al., 2006; van der Maaten, 2013). Mund et al. (2010) questioned this weakness hypothesis and referred to the fact that 2004 was a heavy mast year with a moist and cool growing season (Fig. S2). They assumed that the ongoing or regionally increasing growth depression in the postdrought year (cp. Granier et al., 2007; Beck, 2011; Mölder \& Leuschner, 2014) was the result of a resource shift from woody biomass toward seed formation to ensure species conservation (Eichhorn $e_{t}^{t}$ al., 2008).

\section{Actual mean ring-width and $\delta^{13} C$-signatures during periods comprising drought years as a function of neighborhood identity}

It seems as if the target trees at our sites growing under regionally typical interspecific competition were generally exposed to lower water stress levels than in conspecific surroundings. This is shown by the less negative absolute stable isotope signatures and smaller ring widths of beeches from pure stands in most years of the periods examined (Figs 4 and 5 ) although statistical significance was reached only in some cases. These results may support our third hypothesis and the assumptions of Skomarkova et al. (2006) and Mölder et al. (2011), who suggested that forest management as well as competitor tree species composition may affect or even exceed the climatic influence on isotope ratios in tree rings. It seems as if beech takes advantage of the reduced competition in mixtures leading to later 
stomatal closure, lower $\delta^{13} \mathrm{C}$-values (Fig. 6) and a delayed cessation of radial growth.

At a given site, the relative increase in $\delta^{13} \mathrm{C}$ arising from drought was only slightly affected by the competitor tree species (Figs 7a and 8a). Only in 2003, stomatal conductance of target tree beeches in mixture with Scots pine might has been reduced to a greater extent than in pure stands of the same Exploratory (Fig. 8a). An ecophysiological explanation could be, that larger crowns (Fig. S3) and hence amounts of leaf material capture greater amounts of sunlight, hence require earlier stomatal closure in order to decrease transpiration rates and water stress, what can also be reflected in tree-ring stable isotope ratios (McDowell et al., 2006). Nevertheless, even though beech in the neighborhood of Scots pine responded disproportionally strong to drought during the dry year 2003 (Fig. 8a), average absolute ${ }^{13} \mathrm{C} /{ }^{12} \mathrm{C}$ ratios of these trees still indicated a lower stress level than target trees in the circumjacent pure stands (Fig. 5).

In 1976, soil water depletion apparently occurred in all Exploratories. Interestingly, very low absolute mean $\delta^{13} \mathrm{C}$-values were observed for the target trees from pure and mixed stands in the Schorfheide-Chorin area although the sandy soils have lowest water storage capacities. This may indicate adaption of the local beech ecolype to severe drought conditions (Peuke et al., 2002; Härdtle et al., 2013; Aranda et al., 2015), as this area is even in normal years one of the driest regions of the country. The missing effect of the midseventies drought on stable isotope ratios in the Exploratory Schortheide-Chorin (Figs 4 and 7a) can further be related to a temperature-induced limitation of photosynthesis in the predrought year accompanied by a relatively low level of precipitation (Fig. S2) what may have induced severe water stress in the forefront of the pointer year 1976.

Summing up, the results of this study indicate that the sensitivity of beech to environmental stressors strongly depends on the competitive pressure it is exposed to. Therefore, the establishment of mixed beech stands adapted to the site conditions is a reasonable silvicultural measure that may contribute to mitigate the effects of droughts on growth patterns of Fagus sylvatica. From a practical point of view, two other aspects are worth mentioning. First, it seems as if the magnitude of competitive complementarity determines the growth response of target beech trees. Second, although the beech trees in monocultures at the Schorfheide-Chorin area showed restricted growth, this shall not be misinterpreted as a lacking tolerance to dry conditions. Ring-widths of these trees quickly recovered in the first year after drought (Dittmar et al., 2003). This result and the $\delta^{1.3} \mathrm{C}$-measurements indicate that the vitality of the local beech ecotype was not irreversibly impaired. There are different potential explanations for this finding. Either this may confirm the repeatedly described importance of provenances from low-precipitation ranges for silvicultural planning to develop concepts of adaptive forest management (Peuke ot al, 2002; Bolte $e^{t}$ al., 2009; Rose $e^{t}$ al., 2009; Härdtle et al., 2013) or it may just reflect a generally high phenotypic plasticity of this species. In agreement with other studies that analyzed climatic impacts on the vigor or growth of beech (e.g. Dittmar et al., 2003; Eichhorn $e^{t}$ al., 2008), our investigation strongly suggest that the drought resistance of this species is clearly stronger as hitherto supposed (see also Schall $e t$ al., 2012). Thus, due to its competitiveness and adaptability especially in the mixtures studied here, a disproportionate skeptical suitability assessment of European beech under a changing climate seems to be questionable.

\section{Acknowledgements}

We thank the managers of the three Exploratories, Kirsten Reichel-Jung, Swen Renner, Katrin Hartwich, Sonja Gockel, Kerstin Wiesner, and Martin Gorke for their work in maintaining the plot and project infrastructure; Christiane Fischer and Simone Pfeiffer for giving support through the central office, Michael Owonibi for managing the central data base, and Markus Fischer, Eduard Linsenmair, Dominik Hessenmöller, Jens Nieschulze, Daniel Prati, Ingo Schöning, François Buscot, Wolfgang W. Weisser, and the late Elisabeth Kalko for their role in setting up the Biodiversity Exploratories project (together with co-author Ernst-Detlef Schulze). The work has been funded by the DFG Priority Program 1374 Infrastructure-BiodiversityExploratories' (Grant No: Am-149/7-1). Field work permits were issued by the responsible state environmental offices of Baden-Württemberg, Thüringen, and Brandenburg (according to $\$ 72 \mathrm{BbgNatSchG).} \mathrm{We} \mathrm{are} \mathrm{very} \mathrm{grateful} \mathrm{to} \mathrm{Karl-Heinz} \mathrm{Heine}$ and Ulrike Westphal for assisting field as well as laboratory work and to our colleagues from the department of Plant Ecology and Ecosystem Research for granting access to their core microtome.

\section{References}

Aertsen W, Yanssen E, Kint V, Bontemps Y, van Orshoven Y, Miuys B (2014) Long-term gruwth changes of common beech (fagus sylvatica L.) are less pronounced on highly productive sites. Forest Ecology and Managernent, 312, 252259.

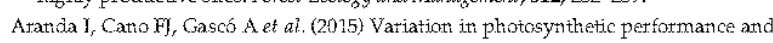
hydratlic architecture across European beech (Fagus sylvatica L.) populations supports the case for local adaptation to water stress. Tree Phasiology, 35, 3446.

Baillie M, Pilcher ) (1973) A simple crossdating prugram for tree-ring reseatch. Tree-Ring Bulletin, 33, 714 .

Batbatcux C, Btéda N (2002) Conttastitic distribution and seasonal dynamics of carbohydrate teserves in stem wood of adult ring-porous sessile oak and diffuseporous beech trees. Tree Phusiolory, 22, 12011210 .

Beck W (2007) Sensitivität und Autokotrelation in Jahrring-Zeitreihen vor: Fichten und Buchen. Sensitivity and atitocortelation in tree ting series of spruce and beech. BFH-Nachrichten, $45,272 \%$

Beck W (2011) Impact of drought and heat on tree and stand vitality - results of the study commissioned by the Federal Ministry of Food, Agriculture and Consumer Ptotection. In: TRACE. Tree Rings in Archazology, Clinatology and Ecology. Scientific 
918 J. METZ et al.

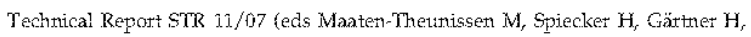
Helle G, Heintich I), pp. 20 27, GFZ, Potsdam.

BMELV (2019) Widhbericht der Bundesregierung 2005. Bundesniristerium für Ernahrutng, Latd wirtschaft utd Vetbraucherschutz (BMELV), Betlit.

Bogeat-Ttiborlot M, Btosché M, Renaut $\mathrm{Y}$ et al. (2007) Gtadual soil water depletiont results in reversible changes of gene expression, protein profiles, ecophysiology, and growth performance in Poputus exthriativa, a poplar growing in arid regions. Plant Priysivulusy, 143, 876892

Bolte A, Villanueva I (2005) Interspecific competition impacts on the morphoiogy and distribution of fine roots in European beech (Fagus sylzatica $\mathrm{l}$ ). and Norway spruce (Picea abies (L.) Karst.j. European Yournal of Forest Research, 125, 1526.

Bolte $A$, Ammer $C$, Lör $M$ et al. (2009) Adaptive forest management in central Europe: climate change impacts, strategies and integrative concept. Scandinautian journal of Forest Research, 24, 473,482

Bolte A, Kampf F, Hilitig $L$ (2013) Space sequestration below grolind in old-growth spruce-beech forests signs for facilitation? Fronticrs in Plant Science, $4,111$.

Boteila S, Letuenberget M, Sautet M, Siegwolf $R$ (1998) Reducing uncertainties in $\delta 13$ $C$ anaiysis of tree tings: pooling, milling, and ceiluiose extraction. Journat of Geophysical Research $103,1051919526$.

Bouriaud O, Bréda N, Moguédec $G$, Nepveu $G$ (2004) Modelling variability of wood detsity in beech as affected by ring age, tadial growth and climate. Trees, 18, 264 275.

Bréda N, Huc R, Gtarier A, Dreyer E (2006) Temperate forest trees and stands under severe drought: a review of ecophysiological responses, adaptation processes and long-term consequences. Annals of For est Science, 63, 625644 .

Btunnet E, Munzed Y (2000) The nonpatametric Behtens-Fisher problem: asymptotic theory and a smail-sample approximation. Biometrical journal, 42, 1725

Bukata AR, Kyser TK (2008) Tree-ring elemental concentrations in oak do not necessatily passively tecotd chatiges it bioavailability. Science of the Total Enviromment, 390,275286

Bunn A (2008) A dendrochtonology program libraty in R (dpliR). Dendrochronologiat 26,115124

Cescatti A, Pitti E (1998) Silvicultural alternatives, competition regine and sensitivity to climate in a Europeart beech forest. Forest Ecoiogy and Management, 102, 213 223.

Christensen Y, Hewitson B, Bustioc A et al. (2007) Regional climate projections. In: Climute Change 2007: The Physical Science Basis. Contribution of Working Gruup I to the Fourth Assessment Report of the Intergovemmertal Panel on Clintate Change (eds Solomon S, Qin D, Mantring Mr Chen $Z$, Marquis M, Averyt K, Tignot M). Cambridge Uriviversity Press, Cambridge, LIK and New York, NY, UTSA.

Ciais P, Reichstein $M$, Viuvy $\mathbb{N}$ et al. (2005) Europe-wide reduction in prinary productivity caused by the heat and drought in 2003. Nature, 437, 529533.

Condess S, Dei Rio M, Stetba H (2013) Mixing effect on volutne growth of Fagus syluatica and Pinus sylvestris is modilated by stand density. Forest Ecology and Management, 292, 8695 .

Cook E, Kairīikšstis $\mathrm{L}(1990)$ Methots of Dendrockronology. Applications in the Envirunmental Science. Kluwer Academic Publishets, Interrational institute for Applied Systems Atralysis, Dotdrecht, Nethetlatnds, Boston, [S.i.], xij, 394.

Curt $T$, Prêvosto $B$ (2003) Root biomass and rooting profile of naturally regenerated beech in nuid-elevation Scots pine woodlands. Plunt Ecology, 167, 269282.

Czajkowski $T$, Kühling M, Bolte A (2005) inpact of the 2003 summet dtought on growth of beech sapling natural tegenetation (Fagus sylwatica $\mathrm{L}$., in noth-eastetn Centual Europe. Allogneine Forst und Jagdreitung, 176, 133143.

D'Amato AW, Bradiord JB, Fraver S, Palik B) (2013) Effects of thinning on drought vulinerability and climate respunse in north temperate forest ecosystems. Ecologival Applications, 23, 17351742.

DeCletck FA, Batbcut $M G_{s}$, Sawyer $\mathrm{YO}(0006)$ Species tichness and stand stability int conifer forests of the Sierra Nevada. Ecolooy, 87, 27872799.

Deutscher Wetterdienst, Offenbach/Germany (2013) Available at: http://www. dwd.de/ accessed 2 Sepitember 2013!

Di. Matteo $G$, de Angelis $P$, Brugnoii E, Cherubiti. P, Scatascia-Mugnozza G (2010) Tree-ring $\Delta^{13} C$ reveals the impact of past forest management on water-11se efficiency in a Mediterranean oak coppice in Tuscany (ftaly). Ankats of Forest Science, 67,510 .

Dittmat C, Elling W (1999) Yahtringbteite von Fichte und Buche in Abhätigigkejt von Witterung und Höhetlage. Forstwissenschafficiches Centralbatat vereinigt mit Tharandter forstliches Jahrlwich, 118, 251270 .

Dittmat C, Zech W, Elling W (2003) Growth variations of common beech (Fayus syluatica L.) under different citnatic and environmental conditions in Europe a dendtcecclogical study. Forest Ecology and Management, 173, 63.78 .
Dulamsuten $C_{r}$ Hauck M, Letuschnet C (2010) Recent drought stress leads to growth reductions in Larix sibirica in the western Khentey, Mongolia. Global Change Biology, 16, 30243035.

Duquestray A, Bteda N, Sievenatd M, Dupouey IL (1998) Changes of tree-ting delta].3C and water-tse efficiency of beech (Fagus sylvatica $\mathrm{X}$.) in north-eastern France during the past century. Plant, Cell and Environment, 21, 565572.

Eckstein D, Bauch ) (1969) Beiłràg zur Rationalisierung eines dendrochrunologischen Verfahrens und zur Analyse seiner Aussagesicherheit. Forstowissenschafllizhes Cerstralblatt, 88, 230250 .

Eichhortn Y, Dammant I, Schönfeider E, Albtecht M, Beck W, Paar U (2008) Untetsuchıingen zur Trocketheitstoleranz der Butche am Beispiei des witterungsextremen Jahres 2043 . Assessment of the drought resistance of beech exemplified by the 2003 extretne weather conditions. In: Ergebnisse angewandter Forschung zur Buthe. Beiträge aus der Norduxstadutschen Forstlichen Versuchsanstait Band 3 led. NW-FVA), FP. 10 139 134. Universitätsveriag Göttingen, Götingen.

Eilmann $B$, Buchmann N, Siegwolf R, Saurer M, Cherubini P, Rigling A (2010) Fast response of Scots pine to improved water availability reflected it tree-titg width and $813 \mathrm{C}$. Plant, Cell \& Enwironment, 33, 1351. 1.360.

Ellenberg H (1096) Vegetation Mittelentropas mit den Aipen in ökologischet, dynamischer und historischer Sicht. 170 Tabelien. Uimer, Stutitgart, $1095 \mathrm{~S}$.

Falumeir L, Kneib $T$, Lang $S$ (2) Regressior. Modelie, Methoden tind Anwendungen. Stringer-Verlag, Berlin, Heidelbetg, New York.

Fatquhat GD, Ehleritiget JR, Hubick KT (1.989) Carbon isotope djsctimitiation and photosynthesis. Annual Reorew of plant Prajsiology and Plant Molenular Biology, 40, $50353 \%$

Fekedulegn D, It Hicks, Ray R, Colbert I) (2003) Influence of topogtaphic aspect, precipitation and drought on tadial growth of four major tree species in an Appalar chian watershed. Forest Ecology and Management, 177, 409 425 .

Fischer M, Bossdorf $\mathrm{O}$, Guckel $S$ et al. (2016) Implementing large-scale and long-term functional biodiversity teseatch: the Biodiversity Exploratories. Basic and Applied Esology, 11, 473485.

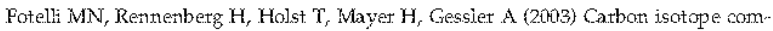
position of varions tissues of beech (Fagus sylvatica) regenteration is indicative of fecent envirunmental conditions within the forest understorey. New Phytologist, 159,229244 .

Fotelii MN, Nahum M, Radogiou K, Rennetbetg H, Haiyvopoulos G, Matzatakis A (2009) Seasonal and interantrual ecophysiological tesponses of beech (fägus słluztica) at its south-eastern distribution limit in Europe. Forest Ecology and Management, $257,11571164$.

Fritts HC (1976) Tree Rings and Climate. Academic Ptess, London, xij, 567.

Gärtnet $H$, Nievergelt D (2010) The core-mictotome: a new tool for surface preparatiun un cures and time series analysis of varying cell parameters. Denutrochrorwivgia, 28, 8592 .

Gebhardt T, Häberle K, Matyssek R, Schuly C, Ammer C (2014) The mote, the better? Water telations of Norway spruce stands after progressive thintritg. Agrictilitiral and forest Meteorology, 197, 235243.

Geßler A, Schrempp S, Małzarakis A, Mayer H, Rennenberg H, Adams MA (2001) Radiation modifies the effect of water availability on the carbon isotone composition of beech (fagus sylvatica). Naw Phytologist, 150, 653664 .

Granier A, Reichstein M, Brêda N et al. (2007) Evidence for soil water conttol on carbon and water dynamics in European furests during the extremely dry year: 2003. Agricultural and forest Meteorology, 143, 123145.

Hätdtie W, Niemeyet $T$, Assmann $T$ ef al. (2013) Long-term tjends in tree-ting width and isotope signatures $(\delta 13 \mathrm{C}, \delta 15 \mathrm{~N})$ of Fagus sylizatica $\mathrm{L}$. on soils with contrasting water supply. Ecosystems, 16, 14131428.

Hemning DL, Switsur WR, Waterhouse IS, Heaton TH, Carter AH (1998) Clinate vatiation and the stable carbon isotope composition of tee tirg cellulose: at: intercompatison of Quercus robur, Fagus sylvatica and Pinus silvestris. Tellus Series B, 50, 2533.

Intergovemmental Panel on Clinate Change (IPCC) (20\%7) Climate Change 2007: Synthesis Reprott. Summary for Policymakets. Available at: http://www.ipcc.ch / pdf/assessmettit-teport/att/ / syr/at4_syt_spm.pdf (accessed 23 Novembet 2013).

Yacob $A$, Hertel D, Leischner $C$ (2013) On the significance of belowgtound overyielding in temperate mixed forests: separating species identity and species diversity effects. Oikos, 122, 463473 .

Jucket $T$, Eourjauda $O$, Avacaritei $D$, Dănilă $X$, Duduman $G$, Vailadates $F$, Coomes DA (2014) Competition for light and water play contrasting toles in driving diversity productivity telationships in Ihetian forests. joumal of Ecology, 102, 12021213.

Jump AS, Hunt MM, Penuelas Y (2006) Rapid clinate change-related growth decline at the southem ratige edge of Fagus sylvatica. Global Change Biology, 12. 2163.2174 . 


\section{MIXTURES IMPROVE WATER AVAILABILITY OF BEECH 919}

Katile $\mathrm{H}$ (2005) Impact of the drotight in 2003 on intsa- and intert-antritual stem tadial growth of beech and spruce along an altitudinal gradient in the Black Forest, Germany in the Black Furest, Germany. In: TRACE - Tree Rings in Archaeology, Clinatology and Ecology, Volume 4. Ptoceedings of the DENDROSYMPOSIUM 2005. Schriften des Forschutigszentrums Jülich, Reihe Umwelt Vol. b1 (eds Heintich 1, Gärther HMM, Schieset G), pp. 152164.

Kelty M) (2006) The rule of species mixtures in plantation furestry. Forest Ecolory and Managentent, 233, 195204.

Kelty M), Cametor $\mathbb{R}$ (1995) Plot designs for the analysis of species interactions it mixed stands. Commonziealth forestry Review, 74, 322.323.

Knoke T, Anmer C, Stimm B, Mosandl R (2008) Admixing broadleaved to coniferous tree species: a review on yield, ecolugical stability and ecunomics. Eutropean juturat of Forest Research, 127, 89101.

Kohlet M, Sohun y, Nägale G, Bauhus ) (3010) Can dtortght toletance of Norway spruce (Picea abies (L.) Karst.) be increased through thinning? European youmal of Forest Research, 129, 11091118.

Larset $\mathrm{fB}$ (1995) Ecological stability of forests and sustainable silviculture. Forest Ecology and Management, $73,85,96$

Lebourgeois F, Btêda N, ultich E, Granier A (2005) Climate-tree-growth telationships of Elropean beech (Fagus syloatica L.) in the French Permanent Plot Network (RENECOFOR). TrRes, 19, 385401.

Leboutgeois F, Gomez N, Pinto P, Métiat: P (2013) Mixed stands teduce Abies alla tree-ting sensitivity to summer drought in the Vosges mountains, western Europe. Forest Ecology and Management, 303,61 71.

Leuschner C (1998) Mechanismen der Kunkutrenzibuerlegenheit der Rotbuche. In: Berichte der Reiwhold-Tïxen-Gesellschaft (RTG) Vol 10, pp. 5 18. Reithold-TüxenGesellschaft, Münstet.

Leuschner C, Meier KC, Hertel D (2006) On the niche breadth of Fagus syluatica. Soil nutrient status in 50 Central Eurupean beech stands on a brcad range of bedrock types. Annals of Forest Science, 63, 355368 .

Litu $X$, Wang $R$, Leavitt SW, Song $H$, Lindetholm HW, $X_{i} Q$, An $Z$ (2012) Yndividuad and pooled tree-ting stable-catbon isctope seties in Chinese pine from the Nan Wutai tegion, China: common signal and climate telationships. Chemical Geology, $330-331,1726$

Llotet F, Keeling EG, Sala A (2011) Components of tree resilinnce: effects of successive low growth episodes in cla ponderosa pine forests. Oikos, 120, 19091920.

van der Maaten E (2012) Climate sensitivity of radial growth in European beech (Firgus syloatica L.) at different aspects in southwestern Germany. Trees, 26, 777 788.

van det Maaten E (2013) Thinting ptolongs grtowth dutation of Eutopean beech (Fagus syluatica $\mathrm{L}$.) actoss a valley in southwestern Germany. Forest Ecology and Management, 306, 135141.

Maesite FT, Callaway RM, Vailadates F, Lortie C) (2009) Refining the stress-gradient hypothesis for competition and facilitation in plant communities. Joumal of Ecoi$08 y_{3}, 97,199205$.

Martin-Benito D, Chertubini $P_{r}$ Rio M, Canellis I (2008) Growth response to climate and drought in Pinus rigra A.rn. trees of different crown classes. Trees, 22, 363 373.

McCarroll D, Loader N) (2004) Stable isotopes in tree rings. Quaternary Science Revizws, 23, 771 801

McDowell NG, Adams HD, Bailey M, Hess M, Kolb TE (2006) Homeostatic maintenance of ponderusa pine gas exchange in respunse to stand density changes. Ecolosical Applications, 16, 11641182.

Meinen $C_{\text {, }}$ Letuschnet $C_{r}$ Kyan $N$, Hertel D (2099) No evidence of spatial toot system segregation and elevated fine root biomass in muli-species temperate broadleaved forests. Trees, 23,941 950 .

Mérian P, Lebourgeuis F (2011) Size-mediated limate growth relationships in temperate forests: a multi-species aralysis. Forest Ecology and Management, 261, 1382 1.391 .

Wetz Y, Seidel D, Schall P, scheffer D, Schuize E, Ammer C (2013) Crown modeiing by terrestrial laser scarming as an approach to assess the effect of aboveground intra- and interspecific competition on tree growth. Forest Ecology and Management, 310,275288 .

Milios E (2004) The influence of stand development process on the height and volume growth of dominant fagus syivativa L. s.1. trees in the central Khodope Mountains of north-eastern Greece. Forestry, 77, 1726.

Mölder I, Letuschnet $C(014)$ European beech grows bettet and is less dtought sensitive in mixed that in pure statids: tree neighbouthood effects on tadial inctement. Trees, 28, 777792

Mülder I, Leuschmer C, Leuschner HHY (2011) $813 \mathrm{C}$ signature of tree rings and radial increment of Fagrus syluatica trees as dependent on tree neighborhood and climate. Trees, 25, 2152229
Wiillet A (2007) Jahminganalytische Uintersuchtingen zwm Informationsgehalt von Holzkohle-Rïckständen der historischen Meilerköhlevei. PhD Thesis, Albert-LudwigsUniversity, Freiburg, Germany, $177 \mathrm{pp}$.

Murd M, Kutsch WL, Wirth C, Kahl T, Knohi A, Skonarkova MV, Schulze E (2010) The influence of climate and fructification on the inter-antrual variability of stem growth and net primary productivity in an old-orowth, mixed beech forest. Tree Phissiology, 30,689704.

Neubert $\mathrm{K}$, Brunner E (20 / $)$ A studentized pernutuation test for the nun-parametric Behrens-Fisher problem. Comprutational Statistics \& Data Analysis, 51, 51925204

Pacaia SW, Canham CD, Sapotata \}, Silander JA, Kobe RK, Ribbens E (1995) Fortest models defined by field measurements: estimation, error analysis and dyramics. Evelegical Monegraph5, 66, 143.

Peuke AD, Schramil C, Hartung W, Rentenberg H (2002) Identification of droughtsensitive beech ecotypes by physiological patameters. New Phytologist, 154, 373 387.

Piovesan $G$, Miondi F, Di Filippo A, Alessandriri A, Maugeri M (2008) Drưught-drivert growth teduction in oid beech (Fagus sylvatica L.) forests of the central Aperthines, Ytaly, Global Change Biology, 14, 126512.81.

Piutti E, Cescati A (1997) A quartitative anaiysis of the interactions between climatic response and intraspecific competition in European beech. Canadian Journat of Forest Research, 27, 277284

Preizsch H (1995) Zum Eirfluß des Baumverteilungstnusters auf den Bestandeszuwachs. On the effect of the spatial distribution of ttees on the stand Growth. Allgemeine Forst und Jagdzeitung, 166, 190201.

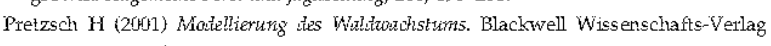
GmbH, Betlit/ Wien.

Ptetzsch $\mathrm{H}$, Schuitze $\mathrm{G}(2005)$ Crown aliometry and growing space efficiency of Notway sprice (Picea abies [L.] Karst.) and European beech (fagus syloatica L.) in pure and mixed stands. Plant Biology, 7, 628639 .

Pretzsch $H$, Schütze $G$ (2009) Transgressive overyielding in mixed compared with pure stands of Norway sprtuce and Eutopean beech in Central Eutope: evidence. on stand level and explanation on individuai tree level. European journal of Forest Research, 128, 183204.

Pretzsch H, Dieler $\}$, Seifert $T$, Rötzer $T$ (2012) Climate effects on productivity and resource-use efficiency of Norway spruce (Picea abies [L.] Katst.) atdd European beech (Fagus sylizatica [L.]) in stands with different spatial mixing patterns. Trees, 26,13431360 .

Pretzsch H, Schiitze G, Ghu E (2013) Resistance of European tree species to drought stress in mixed versus pure forests: evidence of stress release by inter-specific facilitation. Plant Biology, 1.5, 483 4,95.

R Development Core Team (2013) R: A Language and Environment for Statistical Computing. K Develupment Cure Team, Vienna, Austria.

Retunerberg H, Seiler W, Matyssek R, Geiller A, Kteuzwieser f (2004) Die Buche (Fagus syloatica L.) - ein Waldbaum olne Zukurft im südichen Mitteleutopa? Aligemeine Forst und Jagdzeitung, 175, 210244.

Riemet $\mathrm{T}$ (1994) Über die Varianz von Jahrringhreiten. Statistische hikthoden für dite

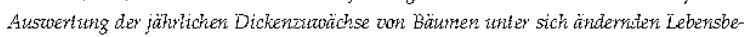
dingungen. PhD Thesis, Utiversity of Göttitigen. Seibstverlat des Forschungszentuums Waldäkosysteme der Universität Göttingen, Göttingen.

Robertson I, Rolfe I, Swritstr VR, Carter AH, Hail MA, Batker AC, Waterhoulse IS (1997) Signal strength and climate relationships in $13 \mathrm{C} / 12 \mathrm{C}$ ratios of tree ring celitulose from oak in southwest Firland. Geophysical Research Letters, 24, 1487 1490 .

Rose L, Leuschner C, Köckemann B, Buschmann H (2009) Ate marginal beech (fagus sylvatica L.) provenances a süurce four drought tulerant ecutypes? Eitropran foumal of Forest Research, 128, 3353 343.

Schall P, Lödige C, Beck M, Ammer C (2012) Biomass allocation to roots and shoots is more sensitive to shade and drought in European beech that in Norway spruce seedlings. Forest Ecology and hänägentent, 266, 246253.

Schär C, Vidale PL, Lüthi D, Frei C, Häberli C, Liniger MA, Appenzeller C (2004) The role of ircreasitg temeerature vatiability it Europeat: surnmer heatwaves. Nature, 427,332335

Scharnweber $T$, Marthey M, Criegee C, Batlwe A, Schröder C, Wilmking M (2011) Drought matters Declining precipitation influences growth of Fagris sylvatica $\mathrm{L}$. and Quercus robut $\mathrm{L}$. it north-eastern Germany. Forest Ecology and Managernent, $262,947,961$.

Schmid I (2002) The influence of soil type and interspecific competition on the fine root system of Norway spruce and European beech. Basic and Applied Ecolosy, 3, 339346.

Schweingruber FH (1983) Der Jahrring. Standort, Methodik, Zeit und Klinna in der Denarochronologic. Verlag Paul Haupt, Bern und St.titigast. 
920 I. METZ et al.

Skomatkova M, Vaganov E, Mtund M, Ktrohl A, Litrke P, Bcerner A, Schtidze E (2005) Inter-anntial and seasonal variability of tadial growih, wood density and carbon isotope ratios in tree rings of beech (Fagus syloatica) growing in Germany and Italy. Trees, 20, 571586.

Schn $\mathrm{Y}$, Gebhatdt $\mathrm{T}$, Ammet $\mathrm{C}$, Bauhus $\mathrm{Y}$, Häbetle K, Matyssek R, Gtams $\mathrm{T}$ (2013) Mitigation of drought by thinning: shott-term and long-term effects on growth and physiological performance of Norway spruce (Picea abies). Forest Ecology a hat Miznayement, 308, 188197.

Solly E, Schöring 1, Boch S, Muiliet I, Sochet SA, Trumbore SE, Schrum of M (2013) Mean age of carbon in fite toots from temperate forests and grasslands with different management. Biogeosciences Discussions, 10, 56715700 .

Tegel W, Seim A, Hakelber' D, Hoffnann S, Panev M, Westphal T, Büntren U (2014) A recerit growth itcrease of European beech (Fagus syluatica L.) at its Meditetranean distribution limit contradicts dicught stress. Eitropean foumal of Forest Research, 133,6171.

Weber P, Bugmann H, Fluess A, Walthert L, Rigling A (2013) Drought response and changing, mean setsitivity of Eutopean beech close to the dry distribution limit. Trees, 27, 171. 181.

Weemstra M, Eilmann B, Sass-Klaassen UG, Sterck $\mathrm{N}$ (2013) Summer dtoughts limit tree growth actoss 10 tempetate species on a productive forest site. Forest Esology and Maragement, 306, 142149.

Zang C, Pretzsch H, Rothe A (2012) Size-depertdert responses to summer drought in Scots pitne, Norway spruce and common cak. Trees, $26,557569$.

\section{Supporting Information}

Additional Supporting Information may be found in the online version of this article:

Figure S1. General information on the study sites located in Northeast-, Central- and Southwest Germany (information on soil properties from Solly et al., 2013).

Figure S2. Monthly mean precipitation sums (bar plots) and monthly mean air temperatures (line graphs) during the growing season for the period 1970-2011.

Figure S3. TLS derived crown surface areas $\left(\mathrm{m}^{2}\right)$ of target tree beeches in spring 2012 that are exposed to either intraor interspecific competition separately for each study area.

Table S1. Relationships between target tree ring-widths and o13Ccorr-values estimated with Pearson's product moment correlation coefficient $(r$ ) for the 4-year periods $1975-1978$ as well as 2002-2005. 


\section{Supporting Information}

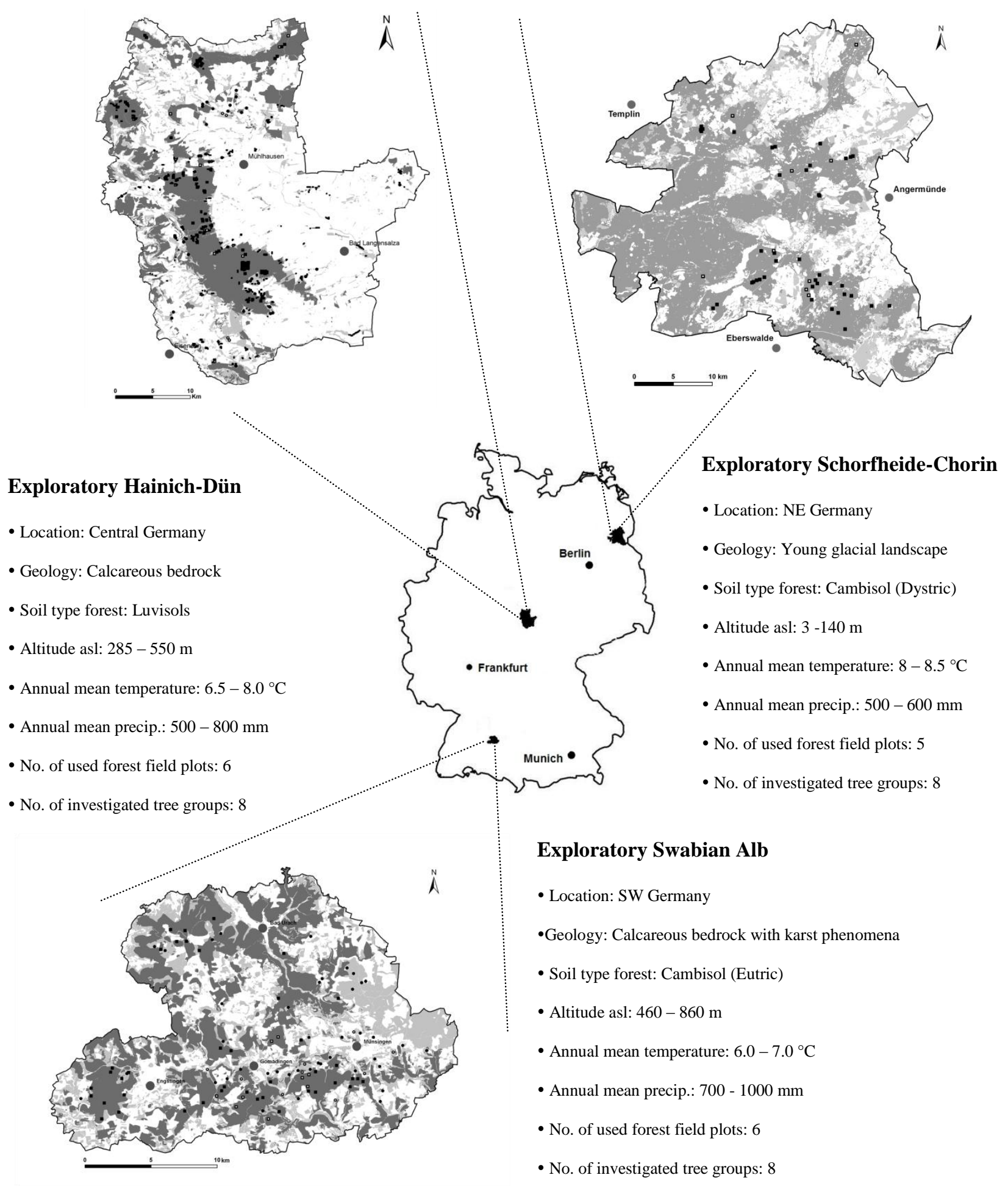

Fig. S1: General information on the study sites located in Northeast-, Central- and Southwest Germany (information on soil properties from Solly et al. 2013). 

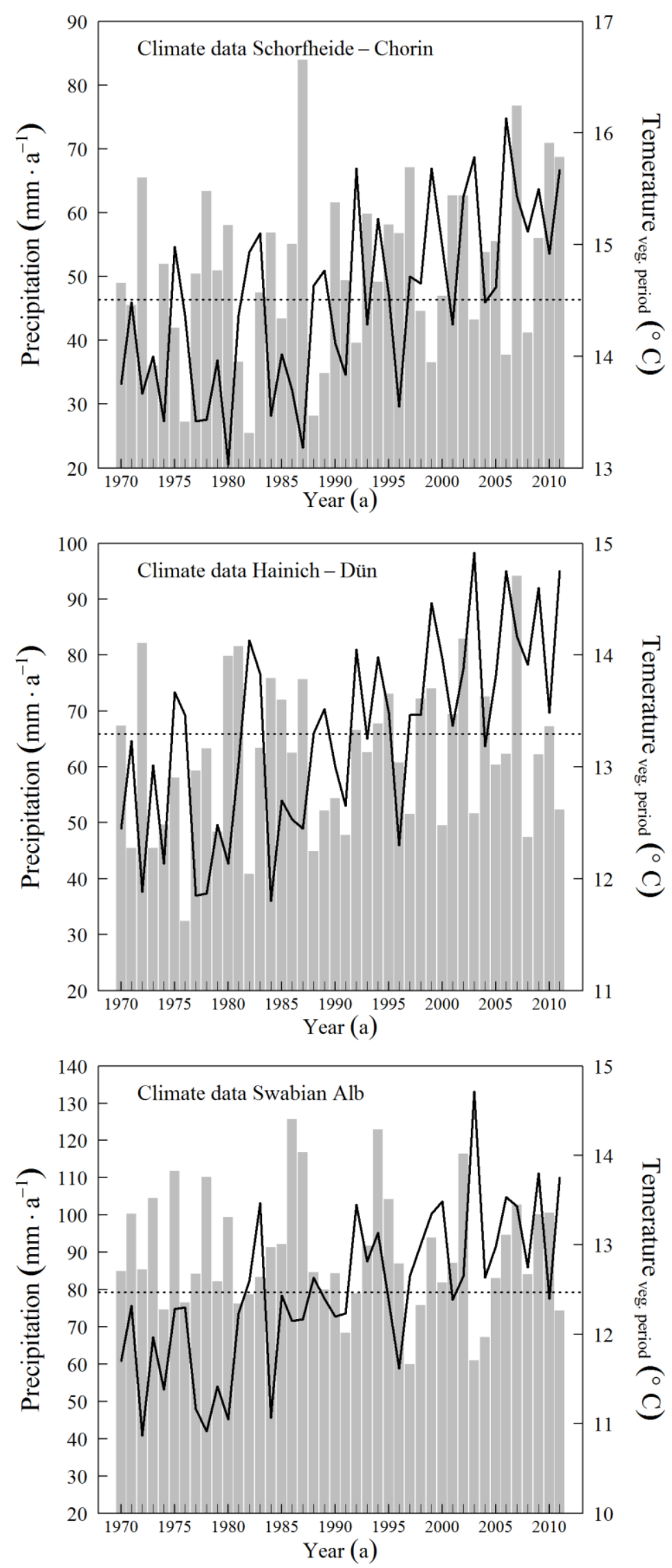

Fig. S2: Monthly mean precipitation sums (bar plots) and monthly mean air temperatures (line graphs) during the growing season for the period 1970-2011. Dotted horizontal lines mark the 41-year average temperature for the interval April to September. 


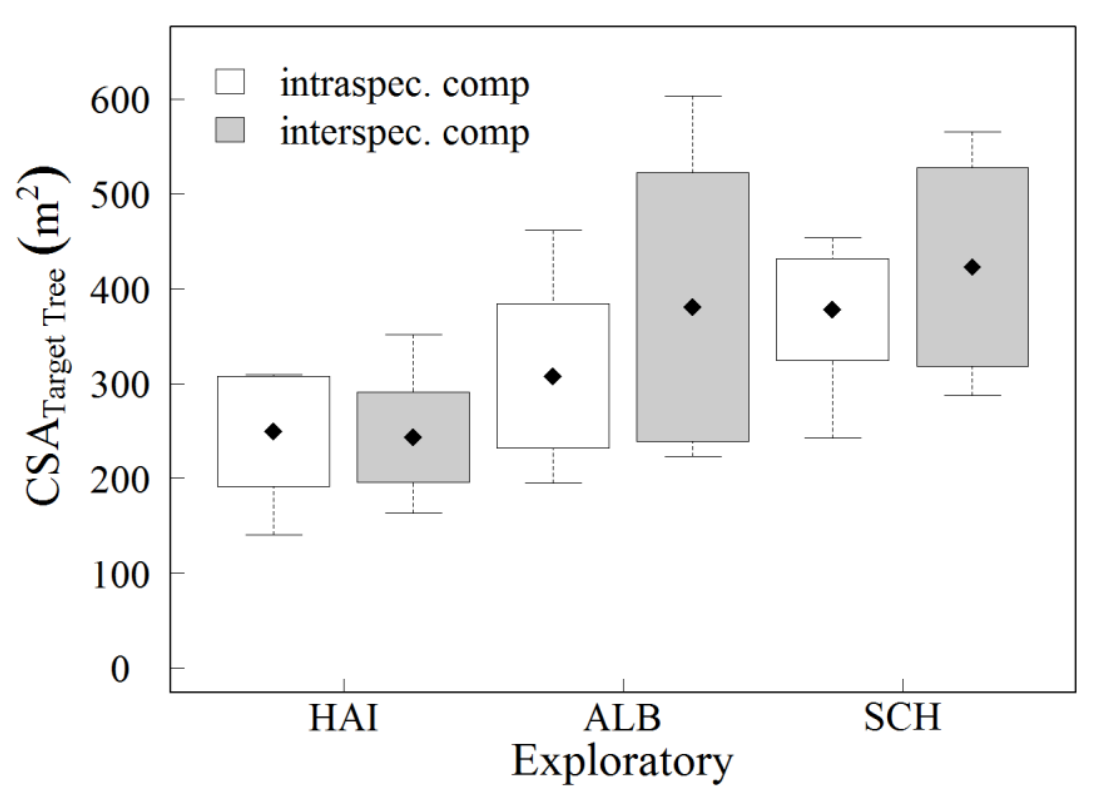

Fig. S3: TLS-derived crown surface areas $\left(\mathrm{m}^{2}\right)$ of target tree beeches in spring 2012 that are exposed to either intra- or interspecific competition separately for each study area. 
Table S1: Relationships between target tree ring-widths and $z^{13} \mathrm{C}_{\text {corr }}$-values estimated with Pearson's product moment correlation coefficient (r) for the 4-year periods 19751978 as well as 2002-2005.

\begin{tabular}{ccccccc}
\hline \multirow{2}{*}{ Target tree } & & & \multicolumn{2}{c}{$1975-1978$} & \multicolumn{2}{c}{$2002-2005$} \\
& Exploratory & Competitor species & $\mathrm{r}$ & $\mathrm{p}$ & $\mathrm{r}$ & $\mathrm{p}$ \\
\hline beech1 & Schorfheide-Chorin & beech & $\mathbf{0 . 9 8}$ & $\mathbf{0 . 0 2}$ & $\mathbf{- 0 . 9 5}$ & $\mathbf{0 . 0 5}$ \\
beech2 & Schorfheide-Chorin & beech & $\mathbf{- 0 . 9 5}$ & $\mathbf{0 . 0 4}$ & 0.04 & 0.96 \\
beech3 & Schorfheide-Chorin & beech & 0.91 & 0.09 & 0.58 & 0.42 \\
beech4 & Schorfheide-Chorin & beech & 0.38 & 0.62 & -0.08 & 0.92 \\
beech5 & Schorfheide-Chorin & pine & $\mathbf{- 0 . 9 5}$ & $\mathbf{0 . 0 4}$ & -0.67 & 0.33 \\
beech6 & Schorfheide-Chorin & pine & $\mathbf{- 0 . 9 9}$ & $\mathbf{0 . 0 1}$ & -0.81 & 0.19 \\
beech7 & Schorfheide-Chorin & pine & 0.26 & 0.74 & -0.83 & 0.17 \\
beech8 & Schorfheide-Chorin & pine & -0.87 & 0.13 & -0.88 & 0.12 \\
beech9 & Hainich-Dün & beech & -0.31 & 0.69 & 0.06 & 0.94 \\
beech10 & Hainich-Dün & beech & -0.81 & 0.19 & 0.93 & 0.07 \\
beech11 & Hainich-Dün & beech & -0.64 & 0.36 & -0.81 & 0.19 \\
beech12 & Hainich-Dün & beech & -0.86 & 0.13 & -0.25 & 0.75 \\
beech13 & Hainich-Dün & val.hardwood & -0.50 & 0.50 & $\mathbf{- 0 . 9 9}$ & $\mathbf{0 . 0 1}$ \\
beech14 & Hainich-Dün & val.hardwood & $\mathbf{- 0 . 9 5}$ & $\mathbf{0 . 0 5}$ & -0.36 & 0.64 \\
beech15 & Hainich-Dün & val.hardwood & -0.23 & 0.77 & -0.34 & 0.66 \\
beech16 & Hainich-Dün & val.hardwood & -0.52 & 0.48 & -0.56 & 0.44 \\
beech17 & Swabian Alb & beech & -0.92 & 0.08 & -0.91 & 0.09 \\
beech18 & Swabian Alb & beech & -0.49 & 0.50 & -0.14 & 0.86 \\
beech19 & Swabian Alb & beech & -0.88 & 0.12 & -0.42 & 0.58 \\
beech20 & Swabian Alb & beech & -0.81 & 0.19 & -0.78 & 0.22 \\
beech21 & Swabian Alb & spruce & -0.88 & 0.12 & -0.68 & 0.32 \\
beech22 & Swabian Alb & spruce & -0.35 & 0.65 & -0.77 & 0.23 \\
beech23 & Swabian Alb & spruce & -0.76 & 0.24 & -0.51 & 0.49 \\
beech24 & Swabian Alb & spruce & -0.80 & 0.20 & -0.93 & 0.07 \\
\hline & & & & & &
\end{tabular}




\section{Chapter 4}

Less is more: Effects of competition reduction and facilitation on intraannual (basal area) growth of mature European beech

Jérôme Metz • Peter Annighöfer • Katharina Westekemper • Peter Schall

- Ernst-Detlef Schulze • Christian Ammer

Reprinted by permission from Springer Nature Customer Service Centre GmbH

Journal publisher: Springer Nature

Journal name: Trees - Structure and Function

Article name: Less is more: Effects of competition reduction and facilitation on intra-annual (basal area) growth of mature European beech

Authors: Metz J, Annighöfer P, Westekemper K, Schall P, Schulze E-D, Ammer C

Copyright: Springer-Verlag GmbH Germany, part of Springer Nature 2019

Year of publication: 2019

Advance online publication: 14 August 2019

DOI: $10.1007 / \mathrm{s} 00468-019-01894-7$

Trees

The final publication is available at:

https://link.springer.com/article/10.1007\%2Fs00468-019-01894-7 
Trees

\title{
Less is more: Effects of competition reduction and facilitation on intra-annual (basal area) growth of mature European beech
}

\author{
Jérôme Metz ${ }^{1}$ D Peter Annighöfer ${ }^{1} \cdot$ Katharina Westekemper ${ }^{1} \cdot$ Peter Schall $^{1} \cdot$ Ernst-Detlef Schulze $^{2}$. \\ Christian Ammer ${ }^{1}$
}

Received: 27 March 2019 / Accepted: 2 August 2019

(c) Springer-Verlag GmbH Germany, part of Springer Nature 2019

\begin{abstract}
Key Message Species-specific neighborhood identity effects such as competition reduction or facilitation can positively influence growth patterns of Fagus sylvatica at a given site, but are not strong enough to overcome fundamental growth-environment interactions of European beech.

Abstract Competition and growth dynamics operating within multi-species tree stands are more complex than interactions within evenly aged monocultures. In three major geographic regions of Germany, we used electronic dendrometers to analyze the impact of neighborhood identity effects such as competition reduction or facilitation on the intra-annual stem growth patterns of Fagus sylvatica (European beech) on various time scales (day to year). Although not consistently significant, within the same study site average basal area growth relative to initial values was always higher at the ends of the growing seasons if subject tree beeches were exposed exclusively to interspecific competition. Weibull growth curves were fitted to rescaled dendrometer profiles. Analysis of the resulting Weibull scale $(T)$ and shape $(m)$ parameter estimates indicated the following: within the same growing area, initial growth trends of beeches in either con- or allo-specific competitive neighborhoods did not differ significantly, but subject trees exclusively surrounded by Pinus sylvestris benefited through extended duration of growth. These findings are reflected in the results for onset, cessation and total duration of wood formation calculated from inverse Weibull functions. Results of this study tend to confirm the assumption that interspecific interference induces higher daily stem growth rates of beech throughout the entire growing season. However, although particular species-specific neighborhood identity or mixing effects can indeed positively influence growth patterns of Fagus sylvatica at a given site, they are not strong enough to overcome fundamental growth-environment interactions of European beech.
\end{abstract}

Keywords Beech $\cdot$ Competition $\cdot$ Mixing effects $\cdot$ Electronic dendrometer $\cdot$ Intra-annual growth dynamics

\section{Introduction}

Forest scientists and practitioners agree that, in view of climate change and due to the long rotation periods intrinsic to forestry, establishment of mixed stands composed of different site-adapted tree species is a silvicultural measure that can reduce biotic and abiotic production risks inherent in management of (coniferous) monocultures (Knoke et al. 2008; Jactel et al. 2009; Ammer 2017). Adaptive and sustainable cultivation of diverse woodland ecosystems requires a deep and detailed understanding of influencing factors, responses to climate, interrelationships controlling stem growth at the individual tree level, and diversity-productivity relationships at the stand level (Duchesne and Houle 2011; van der Maaten et al. 2013; Ammer 2019). Forest management interventions, such as thinnings, as well as 
species composition, affect stand microclimate (Aussenac 2000; Porté et al. 2004; Primicia et al. 2013), hence spatial and temporal resource availability or capture (Ishii and Asano 2010; Jacob et al. 2010b; Pretzsch et al. 2013a).

Analyses of thinning trials in pure stands of different important commercial tree species have shown that reduction in stand density can enhance diameter or basal area growth (Le Goff and Ottorini 1993; Mäkinen and Isomäki 2004; Diaconu et al. 2015) and drought tolerance of remaining future crop trees (Kohler et al. 2010; Sohn et al. 2013) due to reduced levels of intraspecific competition and more efficient resource-use (Gebhardt et al. 2014). Thinning has also repeatedly been shown to facilitate extended durations of growth compared to untreated control plots (Bréda et al. 1995; Hauser 2003; van der Maaten 2013). However, since competition and the resulting growth dynamics of multi-species stands are more complex than competitive interactions in even-aged pure forests (Perot et al. 2010; Larocque et al. 2013), such study results from monocultures are only transferable to a limited extent. With regard to mixed stands, competitive reduction/complementarity, enhanced resource-use efficiency, and facilitation effects are considered key factors in mitigating levels of interference between trees as compared to monocultures (Pretzsch and Schütze 2009; Pretzsch et al. 2010 and 2013a; Morin et al. 2011). Diverse morphological, physiological, or phenological traits determine competitiveness as well as growth dynamics of different tree species, affecting (gross primary) productivity of mixed stands, which can also be defined as total biomass production. In other words, mixing has an impact on one or more of the following three variables (cf. Pretzsch et al. 2012), expressed below in the production ecology equation of Monteith (1977):

$$
\begin{aligned}
\text { GPP } & =\text { resource supply } \\
& \times \text { proportion of resource supply captured } \\
& \times \text { efficiency of resource use. }
\end{aligned}
$$

This applies in particular to Fagus sylvatica, a tree species characterized by high interspecific competitiveness (Ellenberg 1996; Leuschner 1998), but low self-tolerance resulting from strong intraspecific interference in monocultures (Zeide 1985; Pretzsch and Biber 2005; Bosela et al. 2015). As a result it has repeatedly been reported that enrichment of pure beech stands with different admixed tree species can increase the productivity of beech at the stand level (Pretzsch et al. 2010, 2013a, 2015). This finding is largely due to the superior ability of beech to occupy space with tree organs, which increases structural heterogeneity (Pretzsch et al. 2016) and light interception (Forrester et al. 2017). However, another possible but not yet sufficiently clarified mechanism for reduced interspecific competition intensity is temporal rather than spatial or morphological niche differentiation in (beech) mixtures. This strategy may also contribute to an improved supply of the resources necessary for biomass production (Richardson and O'Keefe 2009; Ishii and Asano 2010; Jacob et al. 2010b) and hence better growth of Fagus sylvatica in multi-species stands (Metz et al. 2013, 2016; Mölder and Leuschner 2014). Numerous studies have focused on comparisons of intra-annual growth between (cooccurring) conifers (Fiedler and Wenk 1973; Cuny et al. 2012; Oberhuber et al. 2014), within multi-species broadleaved forests (Jacob et al. 2010b) or among deciduous and evergreen tree species (Vitas 2011; Michelot et al. 2012; Zhai et al. 2012). However, not much is known about seasonal syn- or asynchronism of cambial initiation, diameter growth culmination and growth cessation of a particular tree species (here European beech) in pure as compared to mixed stands in a given research area.

It is, therefore, important to clarify how seasonal growth patterns of Fagus sylvatica differ in intra- and interspecific competitive neighborhoods. The results may help to explain the reduced susceptibility of beech to water limitation during the growing season, seen in regionally typical mixtures (Metz et al. 2016). Information on intra-annual growth can be derived from analyses of wood formation or continuous recordings of stem size variation, but not from retrospective ring width measurements alone (Čufar et al. 2008b; Duchesne and Houle 2011; van der Maaten 2013). To the best of our knowledge, no study has yet made use of high-resolution approaches to characterize beech subject tree growth in different local neighborhoods. We used electronic dendrometers to analyze the impact of neighborhood identity effects such as competition reduction or facilitation on the (intra-annual) stem growth patterns of Fagus sylvatica on various time scales (day to year). We expected competitive reduction (Vandermeer 1989; Kelty 1992; Pretzsch et al. 2010) due to changes in temporal growth dynamics of European beech subject trees in mixed as compared to pure stands.

Based on Kelty and Cameron (1995, p. 322) who stated that "[...] it is necessary to understand competition and other interactions among species, relative to local site conditions, in order to apply results of studies to management situations in an appropriate way $[\ldots]$ ", this study is guided by the following three hypotheses. If local neighborhoods of focal beeches are comparable with respect to quantity, dimensions and spatial arrangement of surrounding trees, within the same investigation area:

1. At the end of vegetation periods 2012 and 2013, (relative) annual basal area growth of European beech trees exposed to interspecific competition is higher than in pure stands (whole-season analysis).

2. Intra-annual growth dynamics of European beech subject trees derived from Weibull functions differ depending on neighborhood composition (conspecifics versus site-adapted admixed tree species).

3. Throughout the entire growing season (month by month comparisons), interspecific interference results in higher 
daily stem growth rates of subject beech trees compared to their growth in monocultures (period analysis).

\section{Methods}

\section{Site description and study design}

The Biosphere Reserves Swabian Alb (=ALB) in southern Germany, Schorfheide-Chorin (=SCH) northeast of Berlin and the Hainich-Dün region (=HAI) in Thuringia (Central Germany) were selected as research sites (Fig. 1); for further details see Fischer et al. 2010. In each of these three large-scale study areas (=Exploratories), 50 permanent and uniformly structured study plots of 1 ha were set up. Field work was conducted on a subset of these 150 forest field plots that are part of the Biodiversity Exploratories research infrastructure (http://www.biodiversity-explo ratories.de/). Monthly precipitation sums and mean air temperatures for the years 2012 and 2013 were recorded

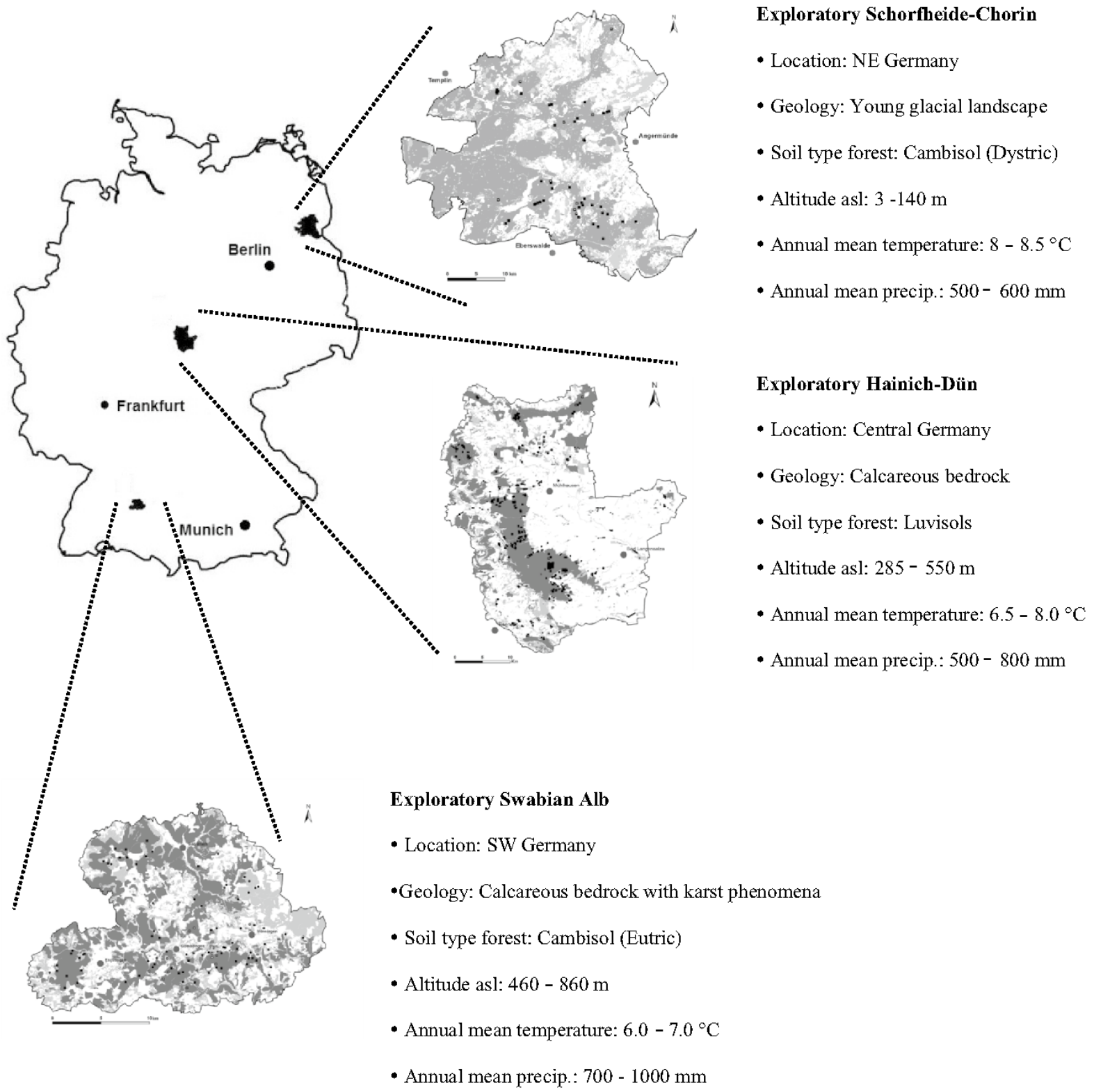

Fig. 1 Overview of geographic locations and site conditions in the three study areas 
by the German National Meteorological Service 'DWD' (Deutscher Wetterdienst 2014) at the weather stations Angermünde/SCH $\left(53.02^{\circ} \mathrm{N} ; 14.00^{\circ} \mathrm{E} ; 54 \mathrm{~m}\right.$ a.s.1 $)$, Leinefelde/HAI $\left(51.24^{\circ} \mathrm{N} ; 10.19^{\circ} \mathrm{E} ; 356 \mathrm{~m}\right.$ a.s.1) and Münsingen-Apfelstetten/ALB $\left(48.23^{\circ} \mathrm{N} ; 09.29^{\circ} \mathrm{E} ; 750 \mathrm{~m}\right.$ a.s.1). Precipitation and temperature during the growing seasons differ markedly along the altitudinal gradient (Table 1). Within the Exploratories, mean temperature differences $\left(\mathrm{SCH}:+0.14{ }^{\circ} \mathrm{C}\right.$; HAI: $-0.19{ }^{\circ} \mathrm{C}$; ALB: $-0.54{ }^{\circ} \mathrm{C}$ ) and total rainfall variation (SCH: -33.4 1; HAI: -5.4 1; ALB: +72.61 ) between the first and second vegetation periods under investigation were relatively small. However, monthly distributions of precipitation differed considerably (Fig. S1 and Table S2).

In the three Exploratories, European beech grows under different site conditions (Tables 1, S2; Figs. 1, S1). Per Exploratory (SCH, HAI and ALB), eight groups, each composed of one central beech with a competitive neighborhood of exactly four enclosing con- or allo-specific trees were selected (Fig. 2). In every Exploratory, half of the tree groups were located in European beech monocultures and the other half in mixed stands representing the prevailing forest composition and species associations of the respective regions (cf. Metz et al. 2013, 2016). The tree groups represent varying degrees of intra- or interspecific interference, so within the same Exploratory, site by site comparisons of growth patterns of focal beeches allowed us to infer the competitive impact of different site-adapted neighboring species typical for the particular region. In the Schorfheide-Chorin area $(\mathrm{SCH})$, sandy soil types that have developed from glacial sediments dominate and annual precipitation is low. Thus, in mixed stands, beech is mainly associated with Scots Pine (Pinus sylvestris). On the more fertile, loess- or limestone-derived soils of the Hainich-Dün region (HAI), multispecies stands of beech and diverse valuable hardwoods (e.g. Fraxinus excelsior, Acer spec., Quercus spec., Ulmus spec. or Tilia spec.) occur. At the more humid and higher-elevation Swabian Alb sites (ALB), Picea abies-Fagus sylvatica mixtures prevail.

A total of 24 subject beech trees (Table 2) were equipped with electronic dendrometers that recorded growth every 30 min during two vegetation periods. The tree groups
Table 1 General weather conditions during the two vegetation periods, related to the duration and magnitude of tree growth in the different study regions

\begin{tabular}{|c|c|c|c|c|c|c|}
\hline \multirow[t]{4}{*}{ Exploratory } & \multicolumn{3}{|c|}{ Year 2012} & \multicolumn{3}{|c|}{ Year 2013} \\
\hline & \multicolumn{2}{|c|}{ Temperature $\left({ }^{\circ} \mathrm{C}\right)$} & $\begin{array}{l}\text { Precipitation } \\
\text { (mm/year) }\end{array}$ & \multicolumn{2}{|c|}{ Temperature $\left({ }^{\circ} \mathrm{C}\right)$} & $\begin{array}{l}\text { Precipitation } \\
\text { (mm/year) }\end{array}$ \\
\hline & \multicolumn{3}{|c|}{ (During vegetation period) } & \multicolumn{3}{|c|}{ (During vegetation period) } \\
\hline & Mean & SD & $\Sigma$ & Mean & SD & $\Sigma$ \\
\hline $\mathrm{SCH}$ & 14.93 & 3.47 & 309.7 & 15.07 & 4.25 & 276.3 \\
\hline HAI & 13.87 & 3.54 & 383.4 & 13.68 & 4.19 & 378.0 \\
\hline ALB & 13.27 & 3.75 & 504.6 & 12.73 & 4.33 & 577.2 \\
\hline
\end{tabular}

intraspecific competition
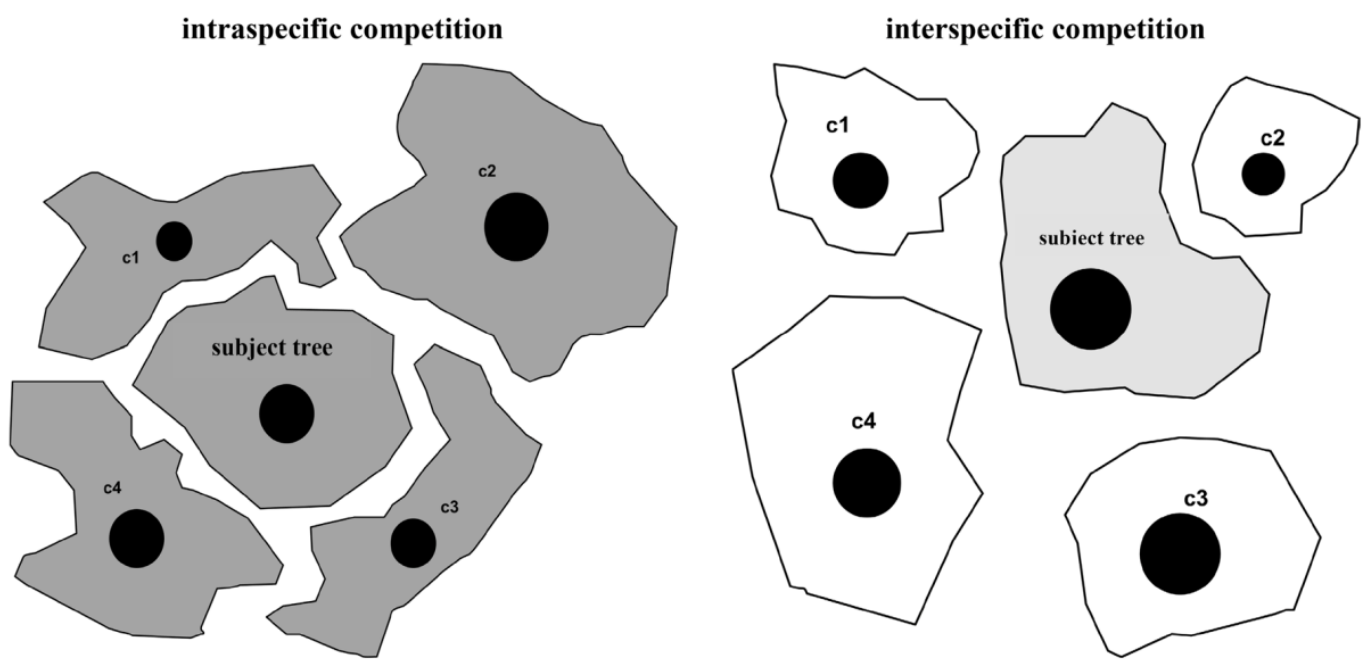

Fig. 2 Subject tree with four competitors (c1-c4) representing pure European beech stands (left) and groups of interspecific neighborhood (right) 
(Fig. 2) were selected according to the following four criteria to eliminate factors other than the neighborhood identity effect from having an impact on beech growth patterns (cf. Metz et al. 2013, 2016). First, whenever possible, the diameter at breast height ( $\mathrm{dbh}$ ) of the subject beech trees (and competing neighbors) should be between 30 and $50 \mathrm{~cm}$ to create suitable conditions for comparisons of annual (basal area) growth patterns. Second, all trees in a group should represent (co-) dominant trees, to avoid sampling and measurement biases resulting from deviating canopy classes. Third, no silvicultural treatments should be applied during the study period to assure continuous competitive conditions. Fourth, to facilitate comparisons, single-layered stands should be preferred.

Here, we define "neighborhood identity" as the taxonomical or functional specificity of competitors surrounding a subject tree. While the term "neighborhood diversity" describes only whether a local neighborhood includes species other than the subject tree, the term neighborhood identity points to the characteristics of the competing species (cf. Mölder and Leuschner 2014). Competitor trees (in our case exactly four) were defined as enclosing trees that had crown contact with the subject tree (cf. Metz et al. 2013).

\section{High-resolution measurement of radial tree growth}

Between March 2012 and October 2013, half-hourly stem girth microvariations of all 24 subject trees were continuously recorded using electronic self-reporting DC2 circumference dendrometers (http://www.ecomatik.de). Intraannual growth dynamics were monitored with electronic dendrometers in this study because they enabled simultaneous growth measurements covering consecutive vegetation periods on numerous trees in areas geographically far apart. The dendrometers were inserted into custom-made stainless steel housings and firmly attached at right-angles to the trunk axes at a height of $1.30 \mathrm{~m}$ above ground level. Tree circumference fluctuations and hence linear displacement of the invar wire were registered via a rectilinear potentiometer that converted the signals into resistance values. In addition to glide rings that minimized friction between wire and bark, when necessary the trunk surface was slightly smoothed to assure that the wire sat solidly on the stem around its entire periphery (cf. Mäkinen et al. 2008; Köcher et al. 2012; Michelot et al. 2012). As the thermal expansion rate of the invar wire that engirds the stem is $<1.4 \mu \mathrm{m} \mathrm{m}^{-1} \mathrm{~K}^{-1}$, it was not necessary to include corrections for thermal expansion or contraction into the process of raw data preparation (cf. Tardif et al. 2001). Furthermore, the computation of percentage information, calculated as the ratio of the measured to the total resistance of the potentiometer, prevented effects of temperature variations on the sensor material from having an influence on the reading. Once daily, through wireless data transfer, the 17 battery-driven or solar-powered Scatter 100 base stations (one base unit per study plot) automatically received the stored percentage values of all dendrometers from the Scatter 100 sensor units/interfaces and sent them to an online database by GSM. Data were stored on integrated SD cards for data backup.

After mounting and necessary readjustments, individual calibration tables were calculated and imported into the evaluation software LOGSTAR. By recursive computation, this communication module converts raw data into the metric units of actual circumference in $\mathrm{mm}$ and growth in $\mu \mathrm{m}$ (cf. Metz et al. 2013). All circumference values were divided by $2 \pi$ to translate them into stem radius information (cf. Tardif et al. 2001; Deslauriers et al. 2007). For some analyses based on absolute growth rates, these data were transformed into basal area growth, because radial growth rates alone disregard possible differences in initial $\mathrm{dbh}$ and are therefore inappropriate productivity measures. All time series graphs plotted in 30-min intervals were visually checked for plausibility so that aberrant data triggered by external interference factors could be located and corrected (cf. Tardif et al. 2001; Duchesne and Houle 2011; van der Maaten 2013). It took about 3 weeks during March 2012 to finish installation work in all Exploratories, so stem radius change of all dendrometers was retroactively zeroed to the reference date April 1 , 2012 ( $=$ beginning of the vegetation period) to ensure data comparability (cf. Tardif et al. 2001). This step of database maintenance was carried out without any adjustment to measuring instruments themselves. The start values (April 1, 2012; $12: 30$ a.m.) of all dendrometers were reset arithmetically. The required calculation was applied analogously to all subsequent measurements of the evaluation period to create a consistent dataset. In the end, a high-quality master data record (Fig. S2 A, F, K) was available for statistical analysis of growth patterns (cf. van der Maaten 2013).

\section{Raw data preprocessing}

Data preparation, preprocessing and statistical evaluation were conducted using the open source statistical language ' $R$ ', version 3.0.2 ( $R$ Development Core Team 2013). The master data record containing continuous half-hourly measurements from both consecutive years (Fig. S2 A, F, K) was initially reduced to the periods from April 1st to September 30th (=vegetation period). In a second step, cumulative radial stem growth was also arithmetically set to zero on cutoff date April 1st 2013, to obtain a consistent database for the multiyear investigations of intra-annual wood formation and total growth rates (Fig. 3a-c).

High-resolution recordings of variations in stem circumference or radius not only measure irreversible dimensional changes due to wood formation based on cambial cell division but also reversible (diurnal) fluctuations that resulted 


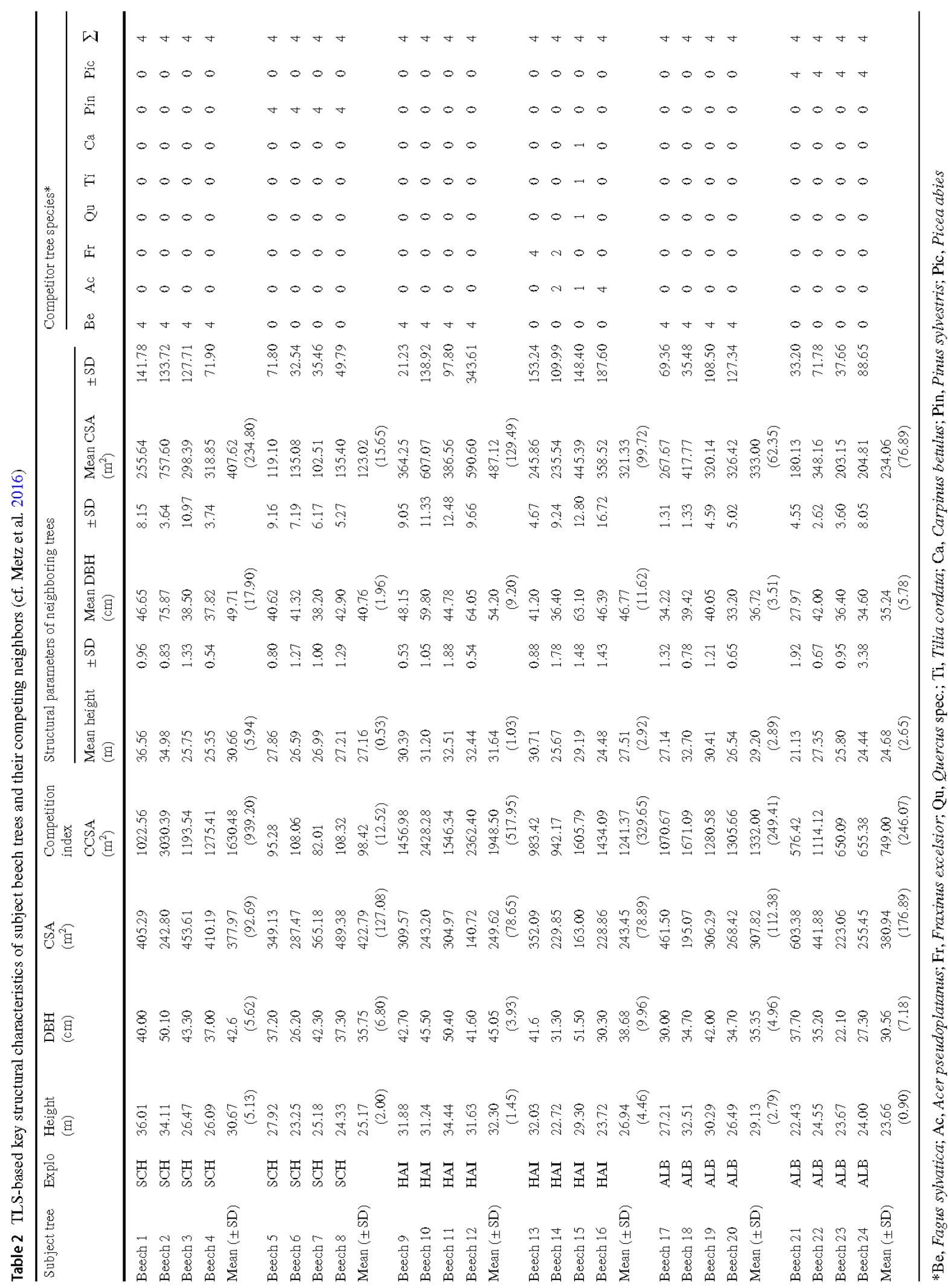

丝 Springer 
from water status-related contraction and expansion of extensible (storage) tissues (see also: Kozlowski and Winget 1964; Herzog et al. 1995; Zweifel and Häsler 2001; Hauser 2003; Mäkinen et al. 2003). Two basic categories for the extraction of stem growth from time series can be distinguished (cf. Deslauriers et al. 2007): first, the daily approach initially reduces all data of 1 day to a single measure either by average determination (cf. Tardif et al. 2001; Oberhuber and Gruber 2010; Duchesne and Houle 2011; van der Maaten et al. 2013; Oberhuber et al. 2014) or by filtering the daily maximum (cf. Bouriaud et al. 2005). Subsequently, the variation in stem dimension is calculated through computation of the difference between two successive values (cf. Duchesne and Houle 2011). Second, the so-called stem cycle approach not only separates shrinking and swelling from real growth on a daily time scale but also determines magnitude as well as duration of the different phases (cf. Downes et al. 1999; Deslauriers et al. 2003, 2011; Köcher et al. 2012) that are linked to sap flow dynamics (Herzog et al. 1995; Köcher et al. 2013). For this study, the extraction of diurnal stem radius variation and the corresponding analysis of (absolute) stem growth rates were based on the daily mean approach (Fig. $3 \mathrm{a}-\mathrm{c}$ ). This method provides results that correlate closely with the time series obtained from the stem cycle algorithm but requires lower programming effort (Deslauriers et al. 2007; Duchesne and Houle 2011; van der Maaten et al. 2013).

\section{Data analysis}

Other dendrometer studies (e.g. Wipfler et al. 2009 and van der Maaten 2013) have shown that intra-annual beech growth patterns can be described well with the cumulative Weibull function (Weibull 1951; Yang et al. 1978; Pretzsch 2001) which reads as follows:

$y=1-\exp \left(-\left(\frac{t}{T}\right)^{m}\right)$

The term $y$ specifies stem radius change relative to total annual radial growth, $t$ the number of days since April 1st. The variable $T$, which is also referred to as scale parameter or characteristic lifetime, quantifies the instant in time when $63 \%$ of the annual radial growth is reached. The shape parameter $m$ is likewise designated as a Weibull module and must take a value greater than 1 because of the sigmoidal curve progression. It increases with declining growth duration and vice versa. When $t=T$, by substitution into Eq. 2, $y(t)$ becomes independent of $m$. Then $y(t)=0.63$ (cf. van der Maaten 2013). Continuous growth data of subject beech trees recorded with electronic self-acting dendrometers was smoothed by estimating Weibull distributions using a nonlinear regression method (cf. Wipfler et al. 2009). Therefore, using the compressed dataset for cumulative radial growth with only one daily mean instead of 48 half-hourly readings (Fig. 3a-c), all seasonal time series of both vegetation periods were initially standardized by dividing every average value through the total stem growth rate at the defined reference date September 30th (Tardif et al. 2001; Wipfler et al. 2009; van der Maaten 2013; van der Maaten et al. 2013). As illustrated in Fig. S2 (B, D, G, I, L, N), the sigmoid Weibull growth curves were subsequently fitted to the rescaled dendrometer profiles (cf. Wipfler et al. 2009; van der Maaten et al. 2013) using the nls2-package for ' $R$ '. This resulted in estimates of $T$ and $m$ which were appropriate for the statistical evaluation of seasonal wood formation dynamics of beech under intra- and interspecific competition. Using the inverse Weibull function,

$f^{-1}(t)=T \times(-\log (1-y))^{(1 / m)}$,

onset, completion, and total duration of wood formation were approximated by determining the point in time (expressed as the number of days elapsed since April 1st) when $5 \%$ and $95 \%$ of annual radial growth had been completed (Henhappl 1965; Beck 2005; van der Maaten et al. 2013). Grouped by Exploratory (SCH, HAI, ALB) and competing neighborhoods (intra- vs. interspecific), average Weibull growth curves for all six subject tree collectives (= subpopulations) were computed. Subsequently, the firstorder derivatives of these mean seasonal radial growth profiles were calculated to examine whether or not increment culmination within the same study region differed between beeches exposed to either intra- or interspecific competition (Fig. S2 C, E, H, J, M, O). Average daily radial growth rates were determined monthly as proxies for diurnal productivity. For this purpose, monthly sums of absolute radial growth (in $\mu \mathrm{m}$ ) were divided by the corresponding number of days separately for every tree.

By evaluating the monotonic relationship between nonnormally distributed empirical data (observed values) and modeled cumulative Weibull distributions, Spearman's nonparametric rank correlation coefficient (rho) was calculated at the individual tree level as a goodness-of-fit measure. The relatively small subsample sizes $(n=4)$ for the intra- or interspecific competition groups in the three different Exploratories did not permit tests on normal distribution or variance homogeneity. Therefore, pair-wise comparisons of means between subpopulations from pure and mixed stands from the same study region were carried out using the npar.t.test function ('nparcomp' package of 'R'). This statistical procedure is applicable to small sample sizes as it considers the nonparametric Behrens-Fisher problem and performs a studentized permutation test (Brunner and Munzel 2000; Neubert and Brunner 2007). It was applied to check for differences between relative as well as absolute growth rates on various time scales, respectively, for the two sample tests with (inverse) Weibull function parameters. Significance 


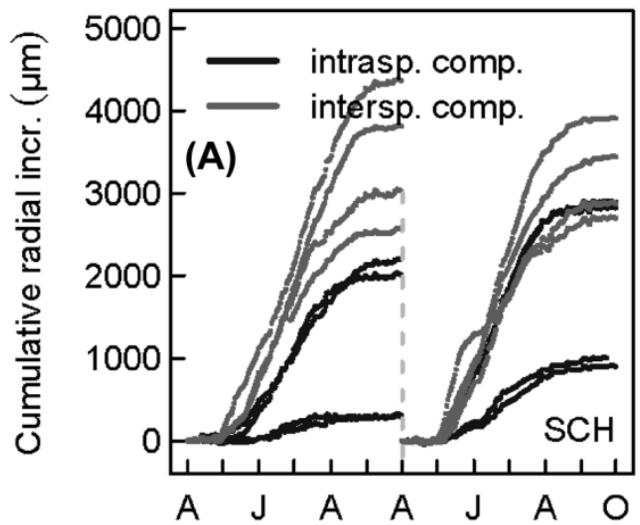

Month
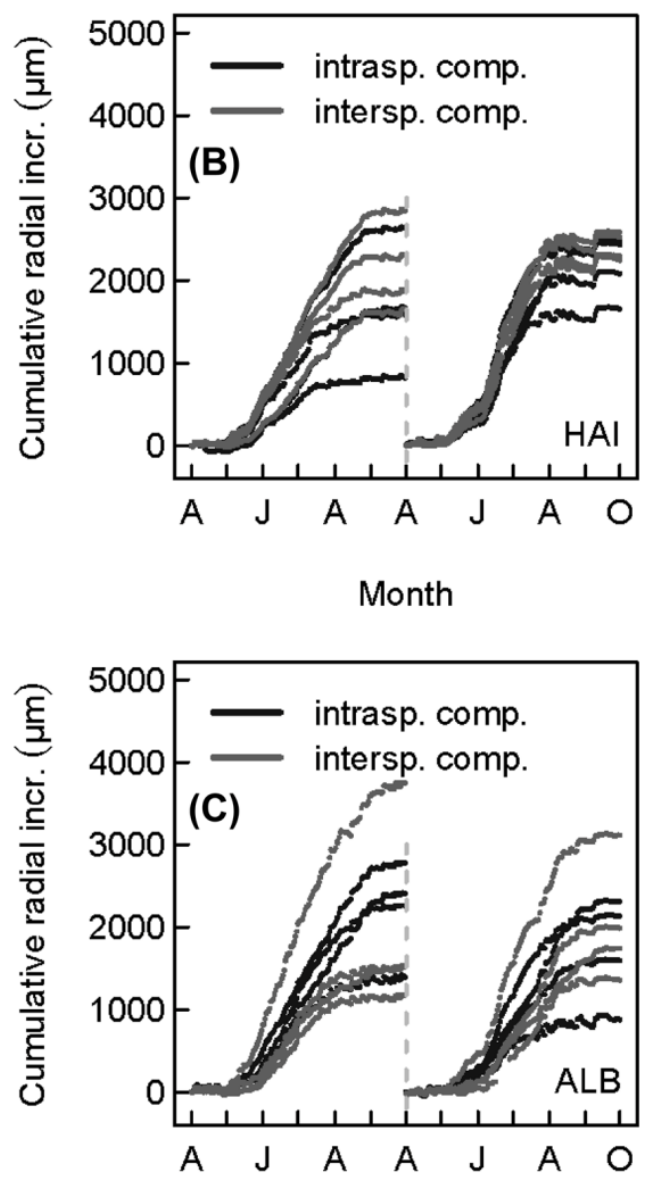

Month

Fig. 3 Fully preprocessed dendrometer data sets for statistical evaluation (vegetation periods 2012 and 2013) with daily mean values from subject tree beeches that are exposed to either intra- or interspecific competition in the Exploratories SCH (a), HAI (b) and ALB (c) level was $p<0.05$ in all tests. We refrained from performing growth response comparisons across sites because only one mixture type was available per region. Climatic variability as well as different edaphic conditions may have had additional confounding effects on data analysis.

To study the relationship between prevailing competitive stress, assessed individually for all subject beech trees, and (relative) basal area growth, linear regression analysis was performed. Thereby, the index CCSA (Competitors' Crown Surface Area) served as the predictor variable. This competition measure (Table 2) considered actual crown shapes of the competing neighbors derived from terrestrial laser scanning (TLS) and their species-specific transmissibility of light (cf. Metz et al. 2013).

\section{Results}

\section{Influence of neighborhood identity on annual basal area growth}

The clustering of the point clouds (Fig. 4c, d) illustrates that competition intensity was lower in groups of interspecific neighborhoods than in beech monocultures (cf. Table 2). Within the same Exploratory, average basal area growth relative to the initial value (BAI in \% in Fig. 4) was invariably higher at the end of both vegetation periods if subject beeches were exclusively exposed to the interspecific competition they encountered in the site-adapted admixed tree species (Fig. 4a, b). However, growth enhancement was consistently significant only in the mixture of beech with Scots pine at the SCH sites. In 2013, beech also grew significantly more in the neighborhood of valuable hardwoods (HAI). A linear regression model with relative basal area growth as response variable and the TLS-based competition index 'CCSA' as predictor revealed a significant negative relationship between competition and relative growth rates in 2012 as well as 2013 (Fig. 4c, d). According to the competition index CCSA which is calculated on the basis of real competitor crown shapes and species-specific transmission coefficients, in most cases competition by admixed species was weaker than competition by conspecific neighbors (cf. Table 2). Therefore, regression analysis indicates that individual subject tree growth was related to neighborhood identity. Average 2013 relative basal area growth (in \%) as well as absolute basal area growth (in $\mathrm{cm}^{2}$ ) was higher compared to the 2012 growing season with the exception of subject trees in the neighborhood of Scots pines ( $\mathrm{SCH}$ ) and beeches from pure stands at the ALB plots. 


\section{Weibull parameter $T$ and $m$}

Averaged coefficients of correlation (Spearman's rho) between Weibull-based predictions of cumulative daily radial growth and observed values calculated separately for the subject tree groups from pure as well as mixed stands of all Exploratories ranged marginally from 0.96 to 1.00 , indicating excellent goodness-of-fit (Table S3). Within the same Exploratory, during the 2-year study, there were no significant differences in Weibull scale parameter $T$ between subject beeches from pure and mixed stands (Fig. 5a, b). This suggests that growth trends of beech trees located in either intra- or interspecific neighborhoods did not diverge until the $63 \%$ point of reference was reached (Fig. 5a, b and Table S3). In comparison to beeches from SCH and HAI, subject trees at the ALB sites tended to achieve this benchmark with a time-lag of several days (Fig. 5a, b and Table S3).

Pair-wise shape parameter $(=m)$ comparisons indicated that beeches exclusively surrounded by Scots pine benefited from extended growth durations even if the nonparametric t-test led to significance only in 2012 (Fig. 5c, d). As suggested by very similar $m$-values, in the HAI region, growth duration of beeches in mixture with valuable hardwoods was only slightly and insignificantly longer (2012) or almost the same (2013) than in the nearby monocultures. In contrast, in the Exploratory ALB, subject trees from pure beech stands exhibited, though not statistically corroborated, a tendency for longer lasting growth durations during both years.

\section{Onset, cessation and total duration of wood formation in days (since April 1st)}

The findings of the Weibull parameters $T$ and $m$ (Fig. 5a-d) were confirmed by the onset, cessation and total duration of wood formation specified in days (since April 1st), that were calculated from inverse Weibull functions (Fig. 5e-j). Only beech trees with Scots pines as competitor trees ( $\mathrm{SCH})$ showed a consistent trend towards earlier beginnings (10/6 days) and later terminations (7/5 days) of cambial activity although the function npar.t.test provided statistical evidence solely for growth initiation in spring 2012 (Fig. 5e-h and Table S4). At the Exploratories HAI and ALB, this general tendency for prolonged growth duration in mixed stands was not observed. Irrespective of the competitive situation, in 2013 especially, dendrometer data revealed that secondary thickening of beech started first in the $\mathrm{SCH}$ lowland area, followed by HAI and ALB sites (Fig. 5e, f and Table S4). Interestingly, with the exception of beeches from pure stands in the $\mathrm{SCH}$ region, total duration of wood formation in 2012 lasted longer than in the subsequent year within all investigation areas (Fig. 5i, j and Table S4).

\section{Timing of intra-annual radial growth culmination}

Although statistically not significant, in interspecific competitive neighborhoods consisting of Scots pine, intraannual culmination of radial growth (i.e., the point where the first-order derivative of mean seasonal radial growth profile is highest) was reached earlier during both years (2012: 6 days; 2013: 7 days). Few differences (2 days in 2012, 1 day in 2013) between mean growth rate maxima of beech trees in pure and mixed stands were found at HAI (Fig. 6 and Table S4). In contrast, at ALB, daily radial growth of subject beech trees surrounded by Norway spruce exhibited non-uniform growth patterns. In 2012, their highest growth was reached 3 days earlier while in 2013 it was statistically significantly later (11 days) than in pure beech stands of the same region (Fig. 6 and Table S4). Daily radial growth of beech in the ALB monocultures culminated on average exactly on the same day (July 3rd) during both years. Regardless of region or mixture type, in 2012, average beech growth culmination was reached almost synchronously between June 25 th and July 3rd (Fig. 6 and Table S4). During the following year, mean maximum growth rates were observed between June 17 th and July 14 th.

\section{Comparisons of daily radial stem growth rates in pure and mixed stands as a proxy for intra-seasonal productivity}

Within each region, the monthly progress of daily stem growth rates under intra- or interspecific competition was almost synchronous (Fig. 7). This finding supports the results of intra-annual growth dynamics based on fits of cumulative Weibull functions for the individual trees (Figs. 5, 6). In each month of both growing seasons, subject trees with neighboring Scots pines ( $\mathrm{SCH}$ ) attained higher average daily growth levels. Comparisons of means yielded statistical significance in 6 out of 12 pair-wise tests (Fig. 7a, b). The lack of statistical evidence in April and September was likely due to the low rate of radial growth in those months. At the HAI sites too, beeches in mixture outperformed their conspecifics in monocultures in all months except for April and August 2013. However, at HAI, the positive effect of interspecific competition was less pronounced. As for beech trees in association with Norway spruce (ALB), only marginal mixture effects on diurnal growth rates occurred in May and June 2012 as well as during the 3-month period from July to September 2013.

Apart from species-specific mixture effects on daily beech growth rates, Fig. 7 illustrates that intra-seasonal radial growth was subdivided into (three) different phases with supra-regional and multiyear validity (see also Fig. S2 B, D, G, I, L, N). After initial swelling (April), wood 

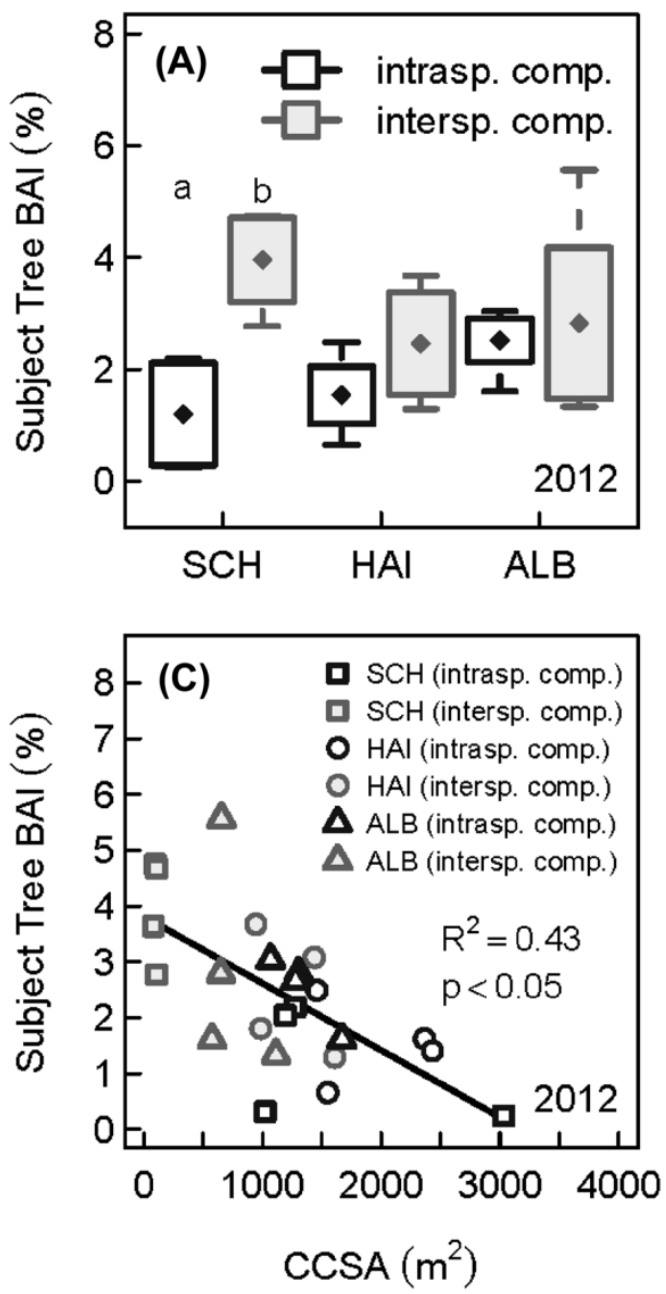

Fig. 4 Relative basal area increment of subject trees being exposed to either intra- or interspecific competition $(\mathbf{a}, \mathbf{b})$ as well as impact of competition intensity (CCSA) on relative BAI of the subject trees (c, d). Different letters above the box-whisker-plots indicate significant

formation and hence growth-related stem radius increase was initiated during May. Almost all subject tree collectives exhibited their highest average daily stem growth rates in June. The only exceptions were the subject beech trees from monocultures at SCH in 2012 and those in the ALB mixed stands during the year 2013. In most cases, average daily growth rates maintained comparable levels in July. This agreed largely with the results of the growth culmination analysis based on first-order derivatives of Weibull growth curves (Fig. 6). During August, secondary thickening strongly decreased and ceased in September. However, depending on the study area, minor temporal shifts emerged over the course of the vegetation period (Fig. 7). Therefore, the monthly growth-rate curves of SCH and HAI were
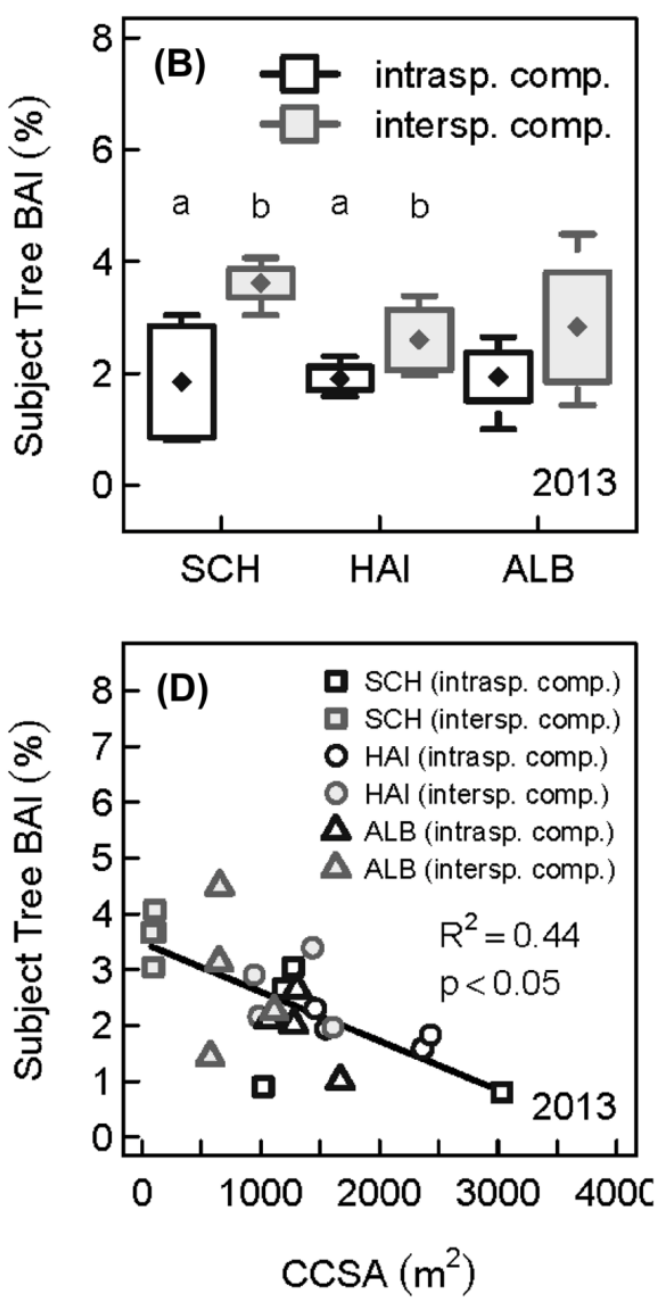

differences between mean BAI (\%) of beeches from the same Exploratory that are growing in groups of intra- or interspecific competition (npar.t.test: $p \leq 0.05$ )

more parabolic than the right- (2012) or left-skewed (2013) sequences from ALB trees.

\section{Discussion}

\section{Influence of neighborhood identity on annual basal area growth}

Relative basal area growth of beeches in site-adapted interspecific neighborhoods was invariably higher than the mean growth rates of subject trees in pure stands of the same region (Fig. 4a, b). This finding confirms our first hypothesis and corresponds with the retrospective results 
Trees

Fig. 5 Temporal variability of subject tree growth under intra- and interspecific

competition derived from cumulative (parameters $T$ and $m)$, respectively, inverse $(\mathbf{e}-\mathbf{j})$ Weibull functions. Lowercase letters above or below the boxwhisker-plots indicate significant differences between subject trees of the same Exploratory that are exposed to either intra-

or interspecific competition

(npar.t.test: $p \leq 0.05$ )
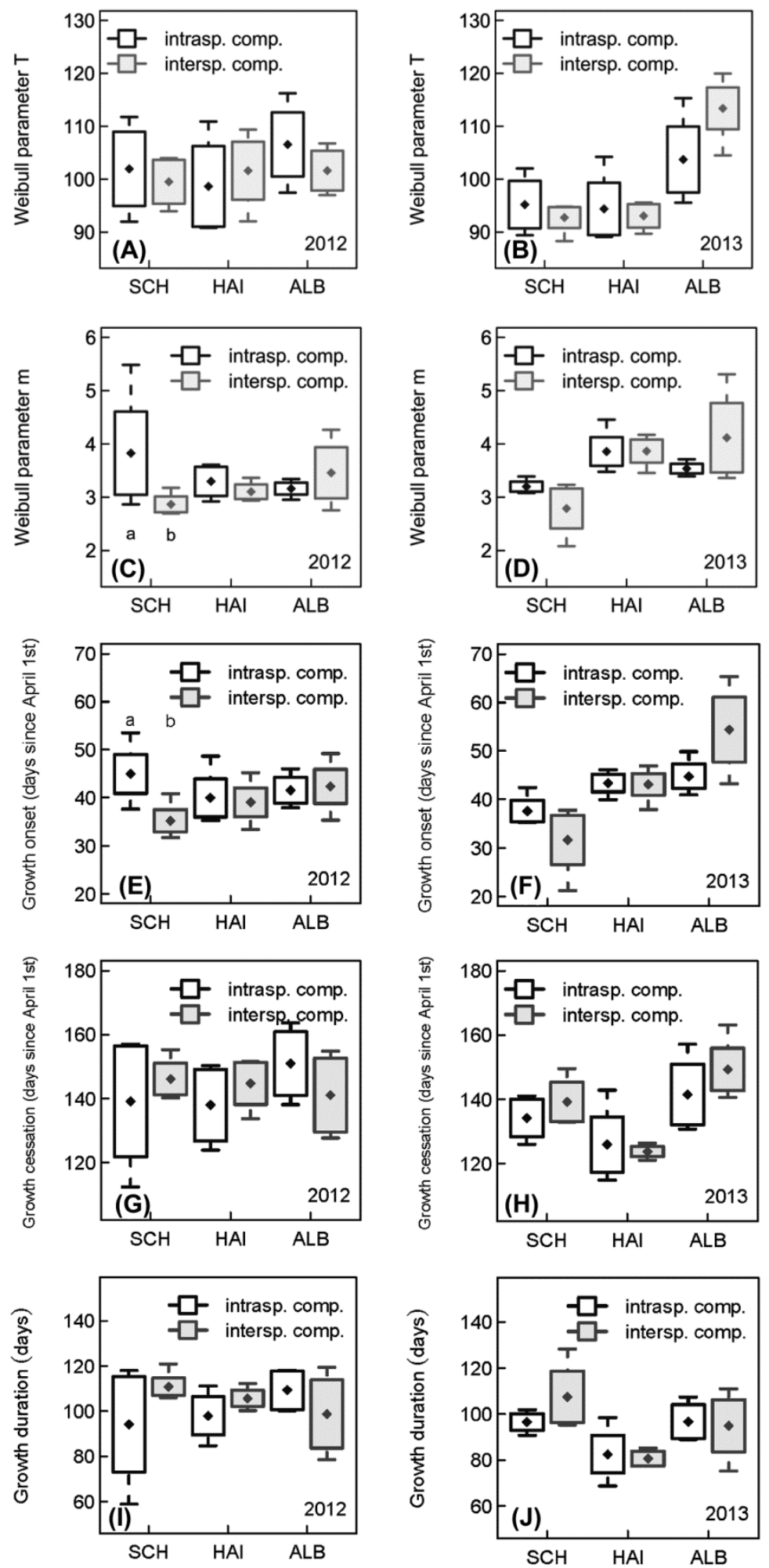


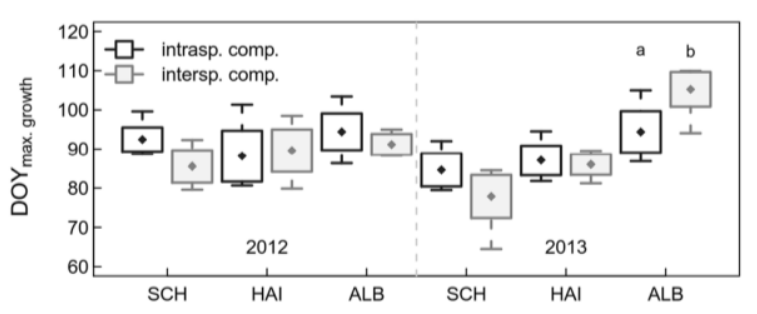

Fig. 6 Comparisons of increment culmination (days elapsed since April 1st) between subject trees of the same study region being exposed to either intra- or interspecific competition. Different letters above the box-whisker-plots indicate significant differences between subpopulations from pure and mixed stands of the same Exploratory (npar.t.test: $p \leq 0.05$ )

of long-term dendrochronological analyses that were previously conducted on the basis of core samples from the same subject trees (Metz et al. 2016). At the ends of both growing seasons, the effect of competition release on beech was most distinct and statistically corroborated in mixture with Scots pine. In general, the extent of mixing effects was influenced by the interaction between prevailing local site conditions (Fig. 1), the complementarity of species-specific ecological niches, and the limiting resource itself (Pretzsch 2005; Forrester et al. 2010; Pretzsch et al. 2012). Thus, in the case of our site by site comparisons, differences in relative basal area growth of subject beech trees with respect to their site-adapted interspecific neighborhoods primarily depended on varying magnitudes of competitive reduction in the mixture. Results of the regression analysis (Fig. 4c, d) suggest that the growth acceleration effect of species mixing on beech diminished with increasing conformity of functional traits (cf. Vandermeer 1989; Kelty and Cameron 1995; Kelty 2006; Morin et al. 2011; Pretzsch et al. 2013b; Metz et al. 2016). In groups with interspecific competition, highest CCSA-values were calculated for valuable hardwoods. Stress levels determined for the conifer species spruce and pine were considerably lower (Table 2). Subject beech trees surrounded by Scots pines benefited from a competitive advantage due to stress release and/or facilitation in mixed forests (Milios 2004; Condés et al. 2013), especially at the low-precipitation and sandy SCH sites with soils of low water retention capacity. This may have been due to the strongly different morphological and physiological properties of the two species (Pretzsch et al. 2015). The small Scots pine crowns (cf. TLS-derived Crown Surface Areas (=CSA) of competing neighbors in Table 2) that form more lighttransmissive and less water transpirating canopies (Pacala et al. 1996; Primicia et al. 2013; Pretzsch et al. 2015), may have benefited the subject beech trees through improving resource availability in comparison to beech monocultures (Metz et al. 2016; Forrester et al. 2017; González de Andrés et al. 2017). Furthermore, beeches in the neighborhood of
Scots pines exhibited the largest crown surface areas carrying assimilation apparatus (Table 2). This is in line with the results of other studies indicating more distinct crown extension of European beech when growing in mixture (Dieler and Pretzsch 2013). Packing density and light interception are increased in mixture (Forrester et al. 2017). Improvements in belowground resource acquisition in mature mixed stands of European beech and Scots pine due to complementary rooting strategies may also play a role (Bonnemann 1939; Pretzsch et al. 2015). For example, Curt and Prévosto (2003) detected higher beech fine-root biomass in all soil layers of natural mixed stands consisting of Pinus sylves tris and Fagus sylvatica to a depth of $75 \mathrm{~cm}$. When mixed with pine, the root system of mature beech is known to be exceedingly adaptive and to become predominant during stand development (Curt and Prévosto 2003).

Competitive neighborhoods composed of valuable hardwoods or Norway spruce also induced superior relative growth performance compared to the subject beech trees from monocultures in the same growing area (Fig. 4a, b). However, at HAI and ALB, the differences in relative basal area growth of subject trees in either con- or allospecific competitive environments were less pronounced than at $\mathrm{SCH}$ and failed to achieve the common level of statistical significance in three out of four nonparametric two sample tests (Fig. 4a, b). The CCSA index indicates that subject beech trees at HAI growing in the neighborhood of conspecifics or valuable hardwoods faced similar aboveground stress levels (Table 2). This suggests that competition-related morphological, physiological, or phenological properties of European beech and the broad-leaved competitor tree species tested in this study (primarily ash and sycamore maple) are closely related (Metz et al. 2016). However, a number of possible mechanisms may have resulted in the observed promoting effect of diverse neighborhoods on beech growth at HAI (cf. Mölder and Leuschner 2014). Light availability, soil water or nutrient status of subject beech trees in competitive neighborhoods consisting of valuable hardwoods might be improved as a consequence of abrasion (Frech 2006), differing water consumption strategies (Gebauer et al. 2008; Köcher et al. 2009), unequal rooting profiles, nutrient pumping or hydraulic lift of water (Rothe and Binkley 2001; Pretzsch et al. 2013b), faster leaf litter decomposition and nutrient release rates (Jacob et al. 2009, 2010a), mycorrhizal symbiosis (Lang 2008; Mölder and Leuschner 2014), variation in the timing of leaf phenology, or differences in the seasonal course of stem growth between (diffuse- and ring-porous) tree species (cf. Suzuki et al. 1996; Barbaroux and Bréda 2002; Michelot et al. 2012).

In mixture with Norway spruce (ALB), the difference in growth between subject beech trees in conspecific and spruce neighborhoods was less intense than aboveground competitive release suggested by the index CCSA led us 
Trees radial growth rates (monthly view) of subject beeches in groups of intra- or interspecific competition. Asterisks label significant differences between subject trees of the same Exploratory that are exposed to either intra- or interspecific competition (npar.t.test: $p \leq 0.05$ )
Fig. 7 Calculated average daily
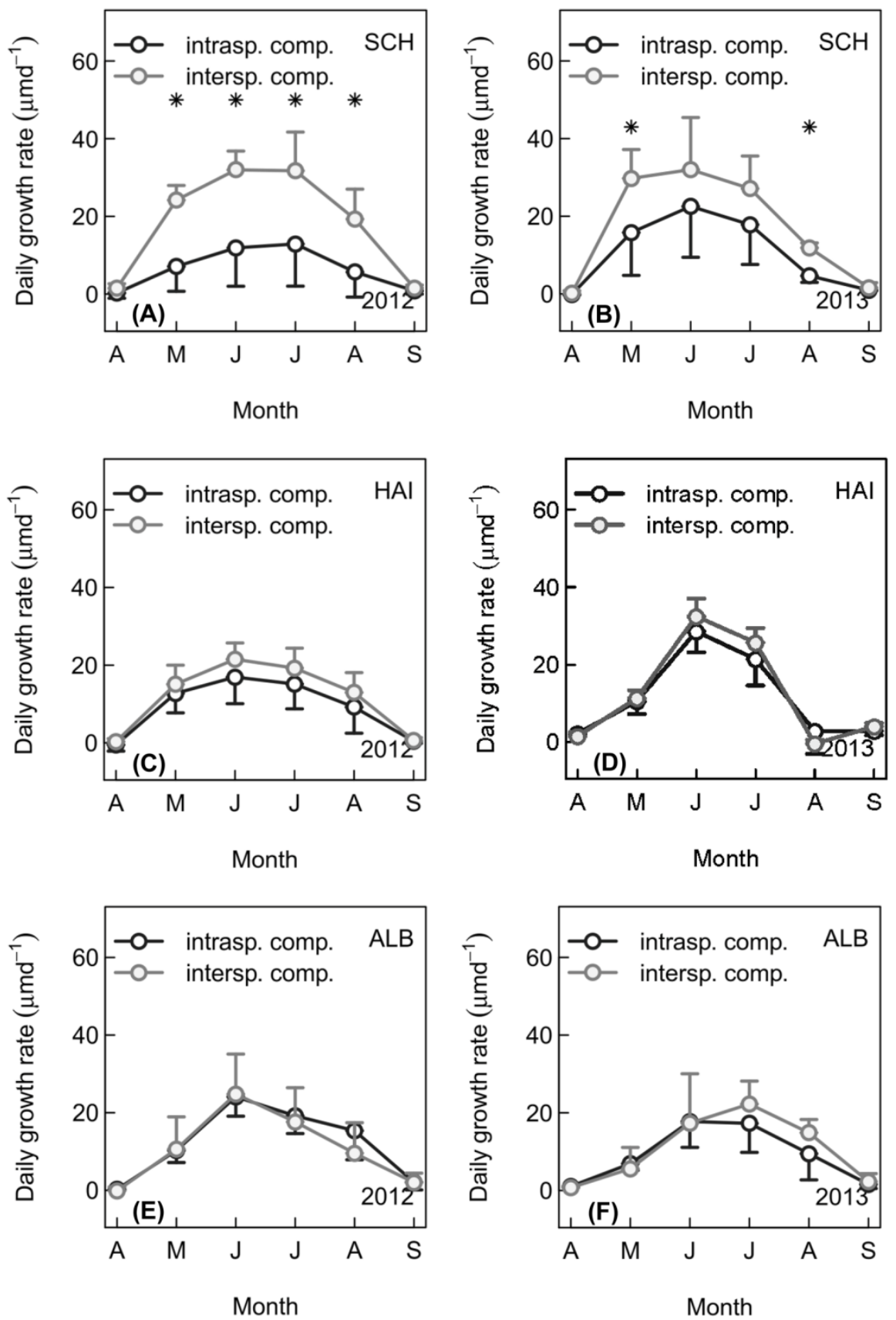

initially to expect (cf. Metz et al. 2016). In mixed stands, European beech is known to be superior in belowground competitiveness compared to Norway spruce (Schmid and Kazda 2001; Schmid 2002; Bolte and Villanueva 2006; Bolte et al. 2013). However, long-term deficits in plant available water do not often occur at the ALB sites due to its typical high precipitation rate during the growing season (Table 1). This suggests that there was enough water for beech not only in mixed but also in pure stands. The observed poor growth-stimulating effect of spruce neighborhoods on subject trees was possibly due to more efficient canopy space occupation and higher photosynthetic performance by beech in mixture with Picea abies (Pretzsch and Schütze 2005, 2009; Pretzsch 2014). However, it was not as pronounced as expected because the availability of the 'pre-emptable' resource light (Schwinning and Weiner 1998) 
and hence subject tree growth performance at our ALB sites may have been limited as total tree height of the surrounding spruce competitors was on average higher (+ $1.02 \mathrm{~m}$, cf. Table 2) than that of the subject beeches (cf. Pretzsch and Schütze 2005, 2009; Pretzsch et al. 2010). It is also possible that despite complementary crown shapes and increased canopy filling (Pretzsch 2014), the growing space efficiency of beech in mixture with spruce was inhibited due to primary biomass investment in crown extension by subject beech trees (Pretzsch and Schütze 2005; Table 2).

\section{Influence of the competitive neighborhood on intra-annual subject tree radial growth}

During the 2-year investigation, radial growth of our subject trees started between early (1st) and late (24th) May, peaked in the period from mid-June (17th) to mid (14th) of July and ended during August (2nd to 29th). Several other European studies on beech growth dynamics have reported similar growth patterns (Barbaroux and Bréda 2002; Hauser 2003; Bouriaud et al. 2004; Knott 2004; van der Werf et al. 2007; Čufar et al. 2008a, b; Ježík et al. 2011, 2016; Michelot et al. 2012). Inter-regional and year-to-year temporal shifts in growth activities are due to differences in local climates (Fig. 1) as well as changing intra-annual weather conditions (Table 1 and Fig. S1). But it seems that intra-annual growth patterns of subject beech trees from pure and mixed stands in the same Exploratory did not fundamentally diverge. However, there was one important exception: Fagus sylvatica surrounded by Pinus sylvestris in the Schorfheide-Chorin area. Hence, as detailed below, our second hypothesis was only partly confirmed.

\section{Weibull parameters $T$ and $m$}

Irrespective of study area, stand type, and year of investigation, the scale parameter values $(=T)$ varied between 92.75 and 113.38 (Table S3). With the exception of the maximum $T$ values derived from ALB beech growth profiles, our curve parameter range corresponded to that provided by Wipfler et al. (2009) and van der Maaten (2013). In contrast to these two studies, we did not find (significantly) higher $T$ values or delayed growth activity of beech under reduced competition. Instead, initial growth trends ( $=T$ values) of our local subject beech tree collectives in either intra- or interspecific neighborhoods did not diverge until the $63 \%$ point of reference was reached (Fig. 5a, b). In the case of broad-leaved tree species such as beech, photosynthetic performance increases with increasing leaf area (MacDougal 1938; Michelot et al. 2012). Thus, it seems that irrespective of the competitor tree species, all subject trees in the same Exploratory were fully foliated within an interval of a few days and reached maximum photosynthesis almost simultaneously (Figs. 6, 7).

In dendrometer analyses, the curve parameter $m$ serves as an absolute (dimensionless) measure for the time necessary to finish wood formation (Wipfler et al. 2009; van der Maaten 2013). At HAI, the lower competitive effect of valuable hardwoods on beech (Table 2) did not affect growth duration of our subject trees (Fig. 5c, d). In contrast, in the neighborhood of Scots pines ( $\mathrm{SCH}$ ), the Weibull module $m$ of subject beech trees was (significantly) lower than in the pure stands of the same Exploratory, implying longer growth durations. This corresponds to the results of beech thinning trials in southern Germany, which suggest that reduced competition intensity through (heavy) thinning induces a prolongation of wood formation (Hauser 2003; van der Maaten 2013). Wipfler et al. (2009) likewise observed increased shape parameter values $(=m)$ of suppressed beech trees indicating shortened growth durations due to higher competition. In contrast to the extended growth period of European beech in mixture with Scots pine, the picture is less clear for trees in neighborhoods exclusively consisting of Picea abies. It seems as if neighboring Picea abies induced slightly shorter subject tree growth durations (Fig. 5c, d). This corresponds with Wipfler et al. (2009), who stated that especially in competitive environments dominated by Norway spruce, the growth duration of beech tended to be curtailed with increasing intertree interference. In the present case, there are two potential explanations. As mentioned above, Picea abies may have pre-empted light through vigorous height growth (Pretzsch and Schütze 2005, 2009; Pretzsch et al. 2010). Second, on the limestone-derived ALB soils which are characterized by low available water capacity, during the 2013 vegetation period, drought stress may have resulted from low precipitation levels (Fig. S1/Table S2) that occurred in July $(54.8 \mathrm{~mm})$ and August $(76.7 \mathrm{~mm})$. Thus, the shallow rooting habit of Picea abies (Schmid 2002) may have reduced water availability for deep-rooted beech in the topsoil stratum (Pretzsch et al. 2010) and hence impaired subject tree growth duration.

\section{Onset, cessation and total duration of wood formation in days (since April 1st)}

The total durations of wood formation in days were calculated as the period between the points in time at which $5 \%$ and $95 \%$ of annual growth had been reached. Across all Exploratories and stand types, the time needed for termination of secondary growth ranged from 81 to 111 days (Fig. 5i, j and Table S4). These values confirm the results of other studies (cf. Hauser 2003; Beck 2005; Čufar et al. 2008a, b; Michelot et al. 2012). 
Distinct but insignificant mixture-related extensions of wood formation were observed in the neighborhood of Pinus sylvestris at the Schorfheide-Chorin sites only (17 days in 2012, and 11 days in 2013). Wood formation of the subject trees in Scots pine neighborhoods began not only (significantly) earlier but ended several days later than in the nearby pure beech stands in both years of investigation (Fig. 5). As budburst of pine occurs after that of beech (Michelot et al. 2012), the earlier growth onset of beech may reflect some kind of phenological escape or competition-avoidance (Richardson and O'Keefe 2009; Cuny et al. 2012) of deciduous beech in mixed stands with evergreen Scots pine. In contrast, the premature basal area increment cessation in monocultures may confirm low self-tolerance ascribed to Fagus sylvatica (Zeide 1985; Pretzsch and Biber 2005). Leaf unfolding and the beginning of beech stem growth are essentially triggered by air temperature and light intensity at the start of the vegetation period (Heide 1993; Suzuki et al. 1996; Čufar et al. 2008a; Mund et al. 2010; Ježík et al. 2011; Michelot et al. 2012; Ježík et al. 2016). Compared to mixed stands of Pinus sylvestris and Fagus sylvatica, sparse pure pine canopies were considered to have a positive impact on these microclimatic variables (Primicia et al. 2013; Pretzsch et al. 2015). The date of growth end was found to have a much stronger influence on total ring width than growth initiation (Michelot et al. 2012). It appears that the growth end in mixture with Pinus sylvestris was positively influenced by improved resource availability to beech due to the thinner, more translucent and water-permeable crowns of Scots pine (Pacala et al. 1996) as well as greater dimensions of subject tree crowns (cf. Table 2). Our findings suggest that variations in intra-annual growth patterns of beech in both pure and mixed stands of the Exploratory SchorfheideChorin were triggered by microclimatic differences. Within the Exploratories HAI and ALB, multiannual data analysis did not reveal a consistent trend towards significantly extended growth durations under interspecific competition. Instead, (especially in 2012) the evaluation procedure based on inverse Weibull functions affirmed the tendency for shorter wood formation time of the subject trees in the beech-spruce mixtures (Fig. 5i, j). It seems as if in these mixtures, potential beneficial effects of lower competition on the growth patterns of subject trees were weak and may have been counterbalanced by small-scale differences in site or weather conditions.

\section{Culmination of radial growth}

It is known that the synchronization of intra-seasonal stem growth culmination is driven by photoperiod and that the maximum number of daylight hours occurs during June (Ježík et al. 2011, 2016). This month is, therefore, crucial for wood formation particularly at lower elevation sites ( ̌ $u f a r$ et al. 2008a; Ježík et al. 2011, 2016). In the HAI region, growth rate maxima of beech exposed to intra- or interspecific interference occurred almost synchronously during both years (Fig. 6). This may be explained by the rather similar traits of beech and the surrounding hardwood species (cf. Metz et al. 2013, 2016). However, at SCH sites, Scots pine neighborhoods led to a clear trend towards an earlier culmination of subject tree growth compared to monospecific beech stands (Fig. 6). During summer and fall, mixed pine-beech canopies are characterized by lower LAI values with associated greater understory day length, soil humidity, and throughfall (cf. Primicia et al. 2013) than beech monocultures, due to the multi-layered leaf arrangement in the crowns of mature Fagus sylvatica trees (Horn 1971). This may have resulted in an earlier dormancy release of subject beech trees in mixture with pine, as sprouting of beech buds is mainly determined by photoperiodism and winter chilling (Heide 1993). The significantly postponed growth culmination of beech in mixture with Norway spruce in 2013 (Fig. 6) may be attributable to another mechanism. As illustrated in Table S2 and Figure S1, in July 2013 the ALB sites were affected by very low precipitation $(54.8 \mathrm{~mm})$. It may be that the soil water reservoirs under pure beech stands were exhausted earlier than in mixture due to the anisohydric traits of Fagus sylvatica (Pretzsch et al. 2013b; Zang et al. 2014). This may have resulted in earlier weather-induced growth cessation in beech monocultures. It is well known that decreased soil water potential has a negative effect on stem growth of (young) beech trees (Mund et al. 2010; Ježík et al. 2016).

\section{Comparisons of daily stem growth rates in pure and mixed stands as a proxy for intra-seasonal productivity}

In our third hypothesis, we stated that throughout the entire growing season, subdivided into monthly segments (Fig. 7), interspecific interference induces higher daily stem growth rates in subject beech trees than intraspecific competition. With one exception (ALB), the results of our study confirm this assumption. Furthermore, Fig. 7 indicates that irrespective of the competitive environment, intra-seasonal progress of European beech stem growth can be subdivided into three main parts. After a phase of swelling and initial growth in spring (April and May), the period of main wood formation occurs during the summer months from June to July followed by growth reduction, cessation and dehydration at the end of the vegetation period. This pattern is well known from other tree species of the northern hemisphere (Belyea et al. 1951; Tardif et al. 2001; Turcotte et al. 2009; Duchesne and Houle 2011). In our study, the monthly progress of daily stem growth rates under intra- or interspecific competition 
within the same Exploratory was almost synchronous (Fig. 7). This suggests that beech growth dynamics are primarily controlled by environmental conditions such as spring temperatures or summer precipitation (Ježík et al. 2011; van der Maaten 2013; Ježík et al. 2016). The species-specific neighborhood identity, and accordingly, the mixing effects, can positively influence daily growth rates of subject tree beeches at a given site, but they are not strong enough to change fundamental growth-environment interactions of Fagus sylvatica (Mölder and Leuschner 2014).

\section{Conclusions}

In all three Exploratories, (relative) stem growth of subject trees from mixed stands composed of Fagus sylvatica and different site-adapted co-occurring species was higher compared to beech monocultures. Compared to subject trees from pure beech stands within the same Exploratory, greater relative basal area growth of beeches in interspecific neighborhoods was observed both under conditions of somewhat different (SCH) or very similar (HAI and ALB) seasonal growth patterns. It appeared that cumulative effects of temporal, spatial, morphological, and physiological niche separation between European beech and Scots pine at $\mathrm{SCH}$ induced a more distinct resource-use optimization by beech than was the case in the other interspecific competitive situations. The greater relative annual basal area growth of subject trees in the neighborhood of valuable hardwoods and spruce was not clearly related to differing seasonal beech growth dynamics in intra- or interspecific competitive neighborhoods. Instead it was most likely linked to other species interaction mechanisms, leading to higher (daily) growth rates during (certain phases of) the vegetation period. In conclusion, the positive impact of interspecific neighborhoods on subject tree growth varies greatly, and is, therefore, context dependent. In other words, competition-related properties of the mixed species, edaphic and climatic conditions, and hence growth-limiting key resources, determine the outcome of competition reduction and/or facilitation. Our results support recent approaches using small-scale enrichment plantings of conifers with different functional traits in pure beech stands across their entire natural range. They also corroborate a conclusion of Kelty and Cameron (1995). These authors stated that if positive species interactions depended on reduced crown or root competition, single-tree mixtures instead of block-wise species combinations would be assumed to improve resource-use efficiency (see also: Pretzsch et al. 2012). Such mixed forests with close interspecific intermingling (Kelty 2006; Pretzsch et al. 2012) may be a reasonable strategy for addressing not only economic needs but also the challenges and uncertainties related to climate change.

Author contribution statement JM, EDS, CA and PS conceived the ideas and designed methodology; JM collected the data; JM, PA, PS and KW analyzed the data; JM and CA led the writing of the manuscript. All the authors contributed critically to the drafts and gave final approval for publication.

Acknowledgements We thank the managers of the three Exploratories; Swen Renner, Kirsten Reichel-Jung, Sonja Gockel, Kerstin Wiesner, Katrin Lorenzen, Andreas Hemp, Martin Gorke, and all former managers for their work in maintaining the plot and project infrastructure; Simone Pfeiffer, Maren Gleisberg, Christiane Fischer for providing support through the central office, Michael Owonibi for managing the central database, and Markus Fischer, Eduard Linsenmair, Dominik Hessenmöller, Jens Nieschulze, Daniel Prati, Ingo Schöning, Francois Buscot, Wolfgang W. Weisser and the late Elisabeth Kalko for their roles in setting up the Biodiversity Exploratories project (together with co-author Ernst-Detlef Schulze). The work was funded by the Deutsche Forschungsgemeinschaft (DFG) Priority Program 1374 "Infrastructure-Biodiversity-Exploratories" (Grant no: Am-149/7-1). Field work permits were issued by the responsible state environmental offices of Baden-Württemberg, Thüringen, and Brandenburg (accord-

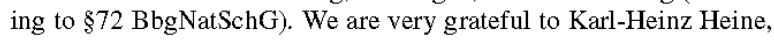
Andreas Parth, Michael Unger and Ulrike Westphal for assisting with field work. Thanks to Ulrich Pruschitzki and Silke Schweighoefer (UP Umweltanalytische Produkte $\mathrm{GmbH}$ ) for their technical support with dendrometer equipment as well as raw data preparation. We further acknowledge the linguistic corrections made by Kathleen Regan (USA) and very helpful comments by two reviewers.

Funding The work has been funded by the Deutsche Forschungsgemeinschaft (DFG) Priority Program 1374 "Infrastructure-BiodiversityExploratories" (Grant no: Am-149/7-1).

\section{References}

Ammer C (2017) Unraveling the importance of inter- and intraspecific competition for the adaptation of forests to climate change. In: Cánovas FM, Lüttge U, Matyssek R (eds) Progress in botany, vol 78. Springer, Cham, pp 345-367

Ammer C (2019) Diversity and forest productivity in a changing climate. New Phytol 221:50-66. https://doi.org/10.1111/nph.15263

Aussenac G (2000) Interactions between forest stands and microclimate: Ecophysiological aspects and consequences for silviculture. Ann For Sci 57:287-301. https://doi.org/10.1051/fores $\mathrm{t}: 2000119$

Barbaroux C, Bréda N (2002) Contrasting distribution and seasonal dynamics of carbohydrate reserves in stem wood of adult ringporous sessile oak and diffuse-porous beech trees. Tree Physiol 22:1201-1210. https://doi.org/10.1093/treephys/22.17.1201

Beck W (2005) Investigation of the interactions between pine and beech in two-layer mixed stands using methods of tree-ring research. In: Gärtner H, Esper J, Schleser G (eds) TRACE - Tree rings in archaeology, climatology and ecology, Vol. 3: Proceedings of the Dendrosymposium 2004. Schriften des Forschungszentrums Jülich, Reihe Umwelt, vol 53, pp 8-16 
Belyea RM, Fraser DA, Rose AH (1951) Seasonal growth of some trees in Ontario. Forest Chron 27:300-305. https://doi.org/10.5558/ tfc 27300-4

Bolte A, Villanueva I (2006) Interspecific competition impacts on the morphology and distribution of fine roots in European beech (Fagus sylvatica L.) and Norway spruce (Picea abies (L.) Karst.). Eur J For Res 125:15-26. https://doi.org/10.1007/ s10342-005-0075-5

Bolte A, Kampf F, Hilbrig L (2013) Space sequestration below ground in old-growth spruce-beech forests - signs for facilitation? Front Plant Sci. https://doi.org/10.3389/fpls. 2013.00322

Bonnemann A (1939) Der gleichaltrige Mischbestand von Kiefer und Buche. Mitt Forstwirtsch u Forstwiss, vol 10. Schaper, Hannover

Bosela M, Tobin B, Šebeň V, Petráš R, Larocque GR (2015) Different mixtures of Norway spruce, silver fir, and European beech modify competitive interactions in central European mature mixed forests. Can J For Res 45:1577-1586. https://doi.org/10.1139/ cjfr-2015-0219

Bouriaud O, Bréda N, Moguédec G, Nepveu G (2004) Modelling variability of wood density in beech as affected by ring age, radial growth and climate. Trees 18:264-276. https://doi.org/10.1007/ s00468-003-0303-x

Bouriaud O, Leban JM, Bert D, Deleuze C (2005) Intra-annual variations in climate influence growth and wood density of Norway spruce. Tree Physiol 25:651-660

Bréda N, Granier A, Aussenac G (1995) Effects of thinning on soil and tree water relations, transpiration and growth in an oak forest (Quercus petraea (Matt.) Liebl.). Tree Physiol 15:295-306

Brunner E, Munzel U (2000) The nonparametric Behrens-Fisher problem: asymptotic theory and a small-sample approximation. Biometrical J 42:17-25

Condés S, Del Rio M, Sterba H (2013) Mixing effect on volume growth of Fagus sylvatica and Pints sylvestris is modulated by stand density. Forest Ecol Manag 292:86-95. https://doi.org/10.1016/j. foreco.2012.12.013

Čufar K, Prislan P, de Luis M, Gričar J (2008a) Tree-ring variation, wood formation and phenology of beech (Fagus sylvatica) from a representative site in Slovenia, SE Central Europe. Trees 22:749 758. https://doi.org/10.1007/s00468-008-0235-6

Cufar K, Prislan P, Gričar J (2008b) Cambial activity and wood formation in beech (Fagtus sylvatica) during the 2006 grow th season. Wood Res Slovakia 53:1-12

Cuny HE, Rathgeber CBK, Lebourgeois F, Fortin M, Fournier M (2012) Life strategies in intra-annual dynamics of wood formation: example of three conifer species in a temperate forest in north-east France. Tree Physiol 32:612-625. https://doi. org/10.1093/treephys/tps039

Curt T, Prévosto B (2003) Root biomass and rooting profile of naturally regenerated beech in mid-elevation Scots pine woodlands. Plant Ecol 167:269-282. https://doi.org/10.1023/A:1023904912712

Deslauriers A, Morin H, Urbinati C, Carrer M (2003) Daily weather response of balsam fir (Abies balsamea (L.) Mill.) stem radius increment from dendrometer analysis in the boreal forests of Québec (Canada). Trees 17:477-484. https://doi.org/10.1007/ s00468-003-0260-4

Deslauriers A, Rossi S, Anfodillo T (2007) Dendrometer and intraannual tree growth: What kind of information can be inferred? Dendrochronologia 25:113-124. https://doi.org/10.1016/j.dendr 0.2007 .05 .003

Deslauriers A, Rossi S, Turcotte A, Morin H, Krause C (2011) A threestep procedure in SAS to analyze the time series from automatic dendrometers. Dendrochronologia 29:151-161. https://doi. org/10.1016/j.dendro.2011.01.008

Deutscher Wetterdienst, Offenbach/Germany (2014). http:/www.dwd. de/. Accessed 16 Apr 2014
Diaconu D, Kahle H-P, Spiecker H (2015) Tree- and stand-level thinning effects on growth of European beech (Fagus sylvatica L.) on a northeast- and a southwest-facing slope in southwest Germany. Forests 6:3256-3277. https://doi.org/10.3390/f6093256

Dieler J, Pretzsch H (2013) Morphological plasticity of European beech (Fagus sylvatica L.) in pure and mixed-species stands. Forest Ecol Manag 295:97-108. https://doi.org/10.1016/j.forec 0.2012 .12 .049

Downes G, Beadle C, Worledge D (1999) Daily stem growth patterns in irrigated Eucalyptus globulus and E. nitens in relation to climate. Trees 14:102-111. https://doi.org/10.1007/PL00009752

Duchesne L, Houle D (2011) Modelling day-to-day stem diameter variation and annual growth of balsam fir (Abies balsamea (L.) Mill.) from daily climate. Forest Ecol Manag 262:863-872. https://doi.org/10.1016/j.foreco.2011.05.027

Ellenberg H (1996) Vegetation Mitteleuropas mit den Alpen in ökologischer, dynamischer und historischer Sicht: 170 Tabellen. UTB, vol 8104, 5th edn. Ulmer, Stuttgart

Fiedler F, Wenk G (1973) Der jahreszeitliche Ablauf des Dickenzuwachses von Fichten und Kiefern und seine Abhängigkeit von meteorologischen Faktoren. Wissenschaftliche Zeitschrift der Technischen Universität Dresden 22:531-535

Fischer M, Bossdorf O, Gockel S, Hänsel F, Hemp A, Hessenmöller D, Korte G, Nieschulze J, Pfeiffer S, Prati D, Renner S, Schöning I, Schumacher U, Wells K, Buscot F, Kalko EKV, Linsenmair KE, Schulze E-D, Weisser WW (2010) Implementing large-scale and long-term functional biodiversity research: The Biodiversity Exploratories. Basic Appl Ecol 11:473-485. https ://doi.org/10.1016/j.baae.2010.07.009

Forrester DI, Theiveyanathan S, Collopy JJ, Marcar NE (2010) Enhanced water use efficiency in a mixed Eucalyptus globulus and Acacia mearnsii plantation. Forest Ecol Manag 259:17611770. https://doi.org/10.1016/j.foreco.2009.07.036

Forrester DI, Ammer C, Annighöfer PJ, Barbeito I, Bielak K, BravoOviedo A, Coll L, Río M, Drössler L, Heym M, Hurt V, Löf M, Ouden J, Pach M, Pereira MG, Plaga BNE, Ponette Q, Skrzyszewski J, Sterba H, Svoboda M, Zlatanov TM, Pretzsch H (2017) Effects of crown architecture and stand structure on light absorption in mixed and monospecific Fagus sylvatica and Pintus sylvestris forests along a productivity and climate gradient through Europe. J Ecol 106:746-760. https://doi. org/10.1111/1365-2745.12803

Frech A (2006) Walddynamik in Mischwäldern des Nationalparks Hainich. Untersuchung der Mechanismen und Prognose der Waldentwicklung. Berichte des Forschungszentrums Waldökosysteme der Universität Göttingen, Reihe A, Vol 196 (Dissertation). Forschungszentrum Waldökosysteme der Universität Göttingen, Göttingen

Gebauer T, Horna V, Leuschner C (2008) Variability in radial sap flux density patterns and sapwood area among seven cooccurring temperate broad-leaved tree species. Tree Physiol 28:1821-1830

Gebhardt T, Häberle K-H, Matyssek R, Schulz C, Ammer C (2014) The more, the better? Water relations of Norway spruce stands after progressive thinning. Agric Forest Meteorol 197:235-243. https ://doi.org/10.1016/j.agrformet.2014.05.013

González de Andrés E, Camarero JJ, Blanco JA, Imbert JB, Lo Y-H, Sanguiesa-Barreda G, Castillo FJ (2017) Tree-to-tree competition in mixed European beech-Scots pine forests has different impacts on growth and water-use efficiency depending on site conditions. J Ecol 106:59-75. https://oi.org/10.1111/1365-2745.12813

Hauser S (2003) Dynamik hochaufgelöster radialer Schaftveränderungen und des Dickenwachstums bei Buchen (Fagus sylvatica L.) der Schwäbischen Alb unter dem Einfluss von Witterung und Bewirtschaftung: Dynamics of radial changes and of radial growth of beech trees (Fagths sylvatica L.) of the Swabian Alb, 
influenced by weather and silvicultural treatments. Dissertation. Fakultät für Forst- und Umweltwissenschaften, Albert-LudwigsUniversität Freiburg, Freiburg im Breisgau

Heide OM (1993) Dormancy release in beech buds (Fagus sylvatica) requires both chilling and long days. Physiol Plantarum 89:187191. https://doi.org/10.1111/j.1399-3054.1993.tb01804.x

Henhappl G (1965) Über die Stärkeänderung der peripheren Stammzone von Waldbäumen im Jahresverlauf. Dissertation, AlbertLudwigs-University, Freiburg im Breisgau

Herzog KM, Hasler R, Thum R (1995) Diurnal changes in the radius of a subalpine Norway spruce stem: their relation to the sap flow and their use to estimate transpiration. Trees 10:94-101

Horn HS (1971) The adaptive geometry of trees. Monographs in population biology, vol 3. Princeton University Press, Princeton

Ishii H, Asano S (2010) The role of crown architecture, leaf phenology and photosynthetic activity in promoting complementary use of light among coexisting species in temperate forests. Ecol Res 25:715-722. https://doi.org/10.1007/s11284-009-0668-4

Jacob M, Weland N, Platner C, Schaefer M, Leuschner C, Thomas FM (2009) Nutrient release from decomposing leaf litter of temperate deciduous forest trees along a gradient of increasing tree species diversity. Soil Biol Biochem 41:2122-2130. https://doi. org/10.1016/j.soilbio.2009.07.024

Jacob M, Viedenz K, Polle A, Thomas FM (2010a) Leaf litter decomposition in temperate deciduous forest stands with a decreasing fraction of beech (Fagus sylvatica). Oecologia 164:1083-1094. https://doi.org/10.1007/s00442-010-1699-9

Jacob M, Leuschner C, Thomas FM (2010b) Productivity of temperate broad-leaved forest stands differing in tree species diversity. Ann For Sci 67:503. https://doi.org/10.1051/forest/2010005

Jactel H, Nicoll BC, Branco M, Gonzalez-Olabarria JR, Grodzki W, Långström B, Moreira F, Netherer S, Orazio C, Piou D, Santos H, Schelhaas MJ, Tojic K, Vodde F (2009) The influences of forest stand management on biotic and abiotic risks of damage. Ann For Sci 66:701. https:/doi.org/10.1051/forest/2009054

Ježík M, Blaženec M, Stř̌elcová K, Ditmarová L (2011) The impact of the 2003-2008 weather variability on intra-annual stem diameter changes of beech trees at a submontane site in central Slovakia. Dendrochronologia 29:227-235. https://doi.org/10.1016/j.dendr 0.2011 .01 .009

Ježík M, Blaženec M, Kučera J, Střelcová K, Ditmarová L (2016) The response of intra-annual stem circumference increase of young European beech provenances to 2012-2014 weather variability. iForest Biogeosci For 2:960-969. https://doi.org/10.3832/ifor1 829-009

Kelty MJ (1992) Comparative productivity of monocultures and mixedspecies stands. In: Kelty MJ, Larson BC, Oliver CD (eds) The ecology and silviculture of mixed-species forests. Kluwer Academic Publishers, Dordrecht, pp 125-141

Kelty MJ (2006) The role of species mixtures in plantation forestry. Forest Ecol Manag 233:195-204. https://doi.org/10.1016/j.forec 0.2006 .05 .011

Kelty MJ, Cameron IR (1995) Plot designs for the analysis of species interactions in mixed stands. Commonw Forest Rev 74:322-332

Knoke T, Ammer C, Stimm B, Mosandl R (2008) Admixing broadleaved to coniferous tree species: a review on yield, ecological stability and economics. Eur J For Res 127:89-101. https://doi. org/10.1007/s10342-007-0186-2

Knott R (2004) Seasonal dynamics of the diameter increment of fir (Abies alba Mill.) and beech (Fagus sylvatica L.) in a mixed stand. J Forest Sci 50:149-160

Köcher P, Gebauer T, Horna V, Leuschner C (2009) Leaf water status and stem xylem flux in relation to soil drought in five temperate broad-leaved tree species with contrasting water use strategies. Ann For Sci 66:101. https://doi.org/10.1051/forest/2008076
Köcher P, Horna V, Leuschner C (2012) Environmental control of daily stem growth patterns in five temperate broad-leaved tree species. Tree Physiol 32:1021-1032. https://doi.org/10.1093/treep hys/tps049

Köcher P, Horna V, Leuschner C (2013) Stem water storage in five coexisting temperate broad-leaved tree species: significance, temporal dynamics and dependence on tree functional traits. Tree Physiol 33:817-832. https://doi.org/10.1093/treephys/tpt055

Kohler M, Sohn J, Nägele G, Bauhus J (2010) Can drought tolerance of Norway spruce (Picea abies (L.) Karst.) be increased through thinning? Eur J For Res 129:1109-1118. https://doi.org/10.1007/ s10342-010-0397-9

Kozlowski TT, Winget CH (1964) Diurnal and seasonal variation in radii of tree stems. Ecology 45:149-155. https://doi. org/10.2307/1937115

Lang C (2008) Diversität der Ektomykorrhizen in verschieden artenreichen Laubbaumbeständen im Nationalpark Hainich (Thüringen). Dissertation Universität Göttingen. Göttinger Forstwissenschaften, Vol 1. Universitätsverlag Göttingen, Göttingen

Larocque GR, Luckai N, Adhikary SN, Groot A, Bell, Wayne F, Sharma M (2013) Competition theory-science and application in mixed forest stands: review of experimental and modelling methods and suggestions for future research. Environ Rev 21:71-84. https://doi.org/10.1139/er-2012-0033

Le Goff N, Ottorini J-M (1993) Thinning and climate effects on growth of beech (Fagus sylvatica L.) in experimental stands. Forest Ecol Manag 62:1-14. https://doi.org/10.1016/0378-1127(93)90038-O

Leuschner C (1998) Mechanismen der Konkurrenzüberlegenheit der Rotbuche. In: Berichte der Reinhold-Tüxen-Gesellschaft (RTG), vol 10, pp 5-18

MacDougal DT (1938) Tree growth. Chronica Botanica Company, Leiden

Mäkinen H, Isomäki A (2004) Thinning intensity and growth of Scots pine stands in Finland. Forest Ecol Manag 201:311-325. https ://doi.org/10.1016/j.foreco.2004.07.016

Mäkinen H, Nojd P, Saranpää P (2003) Seasonal changes in stem radius and production of new tracheids in Norway spruce. Tree Physiol 23:959-968

Mäkinen H, Seo J-W, Nöjd P, Schmitt U, Jalkanen R (2008) Seasonal dynamics of wood formation: a comparison between pinning, microcoring and dendrometer measurements. Eur J For Res 127:235-245. https://doi.org/10.1007/s10342-007-0199-x

Metz J, Seidel D, Schall P, Scheffer D, Schulze E-D, Ammer C (2013) Crown modeling by terrestrial laser scanning as an approach to assess the effect of aboveground intra- and interspecific competition on tree growth. Forest Ecol Manag 310:275-288. https://doi. org/10.1016/j.foreco. 2013.08.014

Metz J, Annighöfer P, Schall P, Zimmermann J, Kahl T, Schulze E-D, Ammer C (2016) Site-adapted admixed tree species reduce drought susceptibility of mature European beech. Global Change Biol 22:903-920. https://doi.org/10.1111/gcb.13113

Michelot A, Simard S, Rathgeber C, Dufrene E, Damesin C (2012) Comparing the intra-annual wood formation of three European species (Fagus sylvatica, Quercus petraea and Pinus sylvestris) as related to leaf phenology and non-structural carbohydrate dynamics. Tree Physiol 32:1033-1045. https://doi.org/10.1093/ treephys/tps052

Milios E (2004) The influence of stand development process on the height and volume growth of dominant Fagtus sylvatica L. s.l. trees in the central Rhodope Mountains of north-eastern Greece. Forestry 77:17-26

Mölder I, Leuschner C (2014) European beech grows better and is less drought sensitive in mixed than in pure stands: tree neighbourhood effects on radial increment. Trees 28:777-792. https://doi. org/10.1007/s00468-014-0991-4 
Monteith JL (1977) Climate and the efficiency of crop production in Britain [and discussion]. Phil Trans R Soc Lond B 281:277-294

Morin X, Fahse L, Scherer-Lorenzen M, Bugmann H (2011) Tree species richness promotes productivity in temperate forests through strong complementarity between species. Ecol Lett 14:12111219. https://doi.org/10.1111/j.1461-0248.2011.01691.x

Mund M, Kutsch WL, Wirth C, Kahl T, Knohl A, Skomarkova MV, Schulze E-D (2010) The influence of climate and fructification on the inter-annual variability of stem growth and net primary productivity in an old-growth, mixed beech forest. Tree Physiol 30:689-704. https://oi.org/10.1093/treephys/tpq027

Neubert K, Brunner E (2007) A studentized permutation test for the non-parametric Behrens-Fisher problem. Comput Stat Data Anal 51:5192-5204. https://doi.org/10.1016/j. csda.2006.05.024

Oberhuber W, Gruber A (2010) Climatic influences on intra-annual stem radial increment of Pinus sylvestris (L.) exposed to drought. Trees 24:887-898. https://doi.org/10.1007/s00468-010-0458-1

Oberhuber W, Gruber A, Kofler W, Swidrak I (2014) Radial stem growth in response to microclimate and soil moisture in a drought-prone mixed coniferous forest at an inner Alpine site. Eur J For Res 133:467-479. https://doi.org/10.1007/s1034 2-013-0777-z

Pacala SW, Canham CD, Saponara J, Silander JA, Kobe RK, Ribbens E (1996) Forest models defined by field measurements: estimation, error analysis and dynamics. Ecol Monogr 66:1-43. https://doi. org/10.2307/2963479

Perot T, Goreaud F, Ginisty C, Dhôte J-F (2010) A model bridging distance-dependent and distance-independent tree models to simulate the growth of mixed forests. Ann For Sci 67:502. https ://doi.org/10.1051/forest/2010004

Porté A, Huard F, Dreyfus P (2004) Microclimate beneath pine plantation, semi-mature pine plantation and mixed broadleavedpine forest. Agric Forest Meteorol 126:175-182. https://doi. org/10.1016/j.agrformet 2004.06.001

Pretzsch H (2001) Modellierung des Waldwachstums. Blackwell, Berlin

Pretzsch H (2005) Diversity and productivity in forests: evidence from long-term experimental plots. In: Scherer-Lorenzen M, Körner Ch, Schulze E-D (eds) Forest diversity and function: temperate and boreal systems, vol 176. Springer, Berlin, pp 41-64

Pretzsch H (2014) Canopy space filling and tree crown morphology in mixed-species stands compared with monocultures. Forest Ecol Manag 327:251-264. https://doi.org/10.1016/j.forec 0.2014 .04 .027

Pretzsch H, Biber P (2005) A re-evaluation of Reineke's rule and stand density index. Forest Sci 51:304-320

Pretzsch H, Schütze G (2005) Crown allometry and growing space efficiency of Norway spruce (Picea abies L. Karst.) and European beech (Fagus sylvatica $\mathbf{L}$.) in pure and mixed stands. Plant Biol 7:628-639. https://doi.org/10.1055/s-2005-865965

Pretzsch H, Schütze G (2009) Transgressive overyielding in mixed compared with pure stands of Norway spruce and European beech in Central Europe: evidence on stand level and explanation on individual tree level. Eur J For Res 128:183-204. https:// doi.org/10.1007/s10342-008-0215-9

Pretzsch H, Block J, Dieler J, Dong PH, Kohnle U, Nagel J, Spellmann H, Zingg A (2010) Comparison between the productivity of pure and mixed stands of Norway spruce and European beech along an ecological gradient. Ann For Sci 67:712. https://doi.org/10.1051/ fores $t 2010037$

Pretzsch H, Dieler J, Seifert T, Rötzer T (2012) Climate effects on productivity and resource-use efficiency of Norway spruce (Picea abies [L.] Karst.) and European beech (Fagus sylvatica [L.]) in stands with different spatial mixing patterns. Trees 26:13431360. https://doi.org/10.1007/s00468-012-0710-y
Pretzsch H, Bielak K, Block J, Bruchwald A, Dieler J, Ehrhart H-P, Kohnle U, Nagel J, Spellmann H, Zasada M, Zingg A (2013a) Productivity of mixed versus pure stands of oak (Quercus petraea (Matt.) Liebl. and Quercus robur L.) and European beech (Fagus sylvatica L.) along an ecological gradient. Eur J For Res 132:263-280. https://doi.org/10.1007/s10342-012-0673-y

Pretzsch H, Schütze G, Uhl E (2013b) Resistance of European tree species to drought stress in mixed versus pure forests: evidence of stress release by inter-specific facilitation. Plant Biol 15:483495. https://doi.org/10.1111/j.1438-8677.2012.00670.x

Pretzsch H, del Río M, Ammer C, Avdagic A, Barbeito I, Bielak K, Brazaitis G, Coll L, Dirnberger G, Drössler L, Fabrika M, Forrester DI, Godvod K, Heym M, Hurt V, Kurylyak V, Löf M, Lombardi F, Matović B, Mohren F, Motta R, den Ouden J, Pach M, Ponette Q, Schütze G, Schweig J, Skrzyszewski J, Sramek V, Sterba H, Stojanović D, Svoboda M, Vanhellemont M, Verheyen K, Wellhausen K, Zlatanov T, Bravo-Oviedo A (2015) Growth and yield of mixed versus pure stands of Scots pine (Pintus sylvestris L.) and European beech (Fagus sylvatica L.) analysed along a productivity gradient through Europe. Eur J For Res 134:927-947. https://doi.org/10.1007/s10342-015-0900-4

Pretzsch H, del Río M, Schütze G, Ammer C, Annighöfer P, Avdagic A, Barbeito I, Bielak K, Brazaitis G, Coll L, Drössler L, Fabrika M, Forrester DI, Kurylyak V, Löf M, Lombardi F, Matović B, Mohren F, Motta R, den Ouden J, Pach M, Ponette Q, Skrzyszewski J, Sramek V, Sterba H, Svoboda M, Verheyen K, Zlatanov T, Bravo-Oviedo A (2016) Mixing of Scots pine (Pinus sylvestris L.) and European beech (Fagus sylvatica L.) enhances structural heterogeneity, and the effect increases with water availability. Forest Ecol Manag 373:149-166. https://doi.org/10.1016/j.forec 0.2016 .04 .043

Primicia I, Camarero JJ, Imbert JB, Castillo FJ (2013) Effects of thinning and canopy type on growth dynamics of Pinus sylvestris: inter-annual variations and intra-annual interactions with microclimate. Eur J For Res 132:121-135. https://doi.org/10.1007/ s10342-012-0662-1

R Development Core Team (2013) R: a language and environment for statistical computing. R Development Core Team, Vienna

Richardson AD, O'Keefe J (2009) Phenological differences between understory and overstory: a case study using the long-term Harvard forest records. In: Noormets A (ed) Phenology of ecosystem processes: applications in global change research. Springer, New York, pp 87-117

Rothe A, Binkley D (2001) Nutritional interactions in mixed species forests: a synthesis. Can J For Res 31:1855-1870. https://doi. org/10.1139/cjfr-31-11-1855

Schmid I (2002) The influence of soil type and interspecific competition on the fine root system of Norway spruce and European beech. Basic Appl Ecol 3:339-346. https://doi. org/10.1078/1439-1791-00116

Schmid I, Kazda M (2001) Vertical distribution and radial growth of coarse roots in pure and mixed stands of Fagus sylvatica and Picea abies. Can J For Res 31:539-548. https://doi.org/10.1139/ $\mathrm{x} 00-195$

Schwinning S, Weiner J (1998) Mechanisms determining the degree of size asymmetry in competition among plants. Oecologia 113:447-455. https://doi.org/10.1007/s004420050397

Sohn JA, Gebhardt T, Ammer C, Bauhus J, Häberle K-H, Matyssek R, Grams TEE (2013) Mitigation of drought by thinning: short-term and long-term effects on growth and physiological performance of Norway spruce (Picea abies). Forest Ecol Manag 308:188197. https://doi.org/10.1016/j.foreco.2013.07.048

Suzuki M, Yoda K, Suzuki H (1996) Phenological comparison of the onset of vessel formation between ring-porous and diffuseporous deciduous trees in a Japanese temperate forest. IAWA J $17: 431-444$ 
Tardif J, Flannigan M, Bergeron Y (2001) An analysis of the daily radial activity of 7 boreal tree species, Northwestern Quebec. Environ Monit Assess 67:141-160. https://doi.org/10.1023/A:10064 30422061

Turcotte A, Morin H, Krause C, Deslauriers A, Thibeault-Martel M (2009) The timing of spring rehydration and its relation with the onset of wood formation in black spruce. Agric Forest Meteorol 149:1403-1409. https://doi.org/10.1016/j.agrformet.2009.03.010

van der Maaten E (2013) Thinning prolongs growth duration of European beech (Fagus sylvatica $\mathbf{L}$.) across a valley in southwestern Germany. Forest Ecol Manag 306:135-141. https://doi. $\operatorname{org} / 10.1016 / j$.foreco.2013.06.030

van der Maaten E, Bouriaud O, van der Maaten-Theunissen M, Mayer H, Spiecker H (2013) Meteorological forcing of day-to-day stem radius variations of beech is highly synchronic on opposing aspects of a valley. Agr Forest Meteorol 181:85-93. https://doi. org/10.1016/j.agrformet.2013.07.009

van der Werf GW, Sass-Klaassen UGW, Mohren GMJ (2007) The impact of the 2003 summer drought on the intra-annual growth pattern of beech (Fagus sylvatica $\mathbf{L}$.) and oak (Quercus robur $\mathbf{L}$.) on a dry site in the Netherlands. Dendrochronologia 25:103-112. https://doi.org/10.1016/j.dendro.2007.03.004

Vandermeer JH (1989) The ecology of intercropping. Cambridge University Press, Cambridge

Vitas A (2011) Seasonal growth variations of pine, spruce, and birch recorded by band dendrometers in NE Lithuania. Baltic For 17:197-204
Weibull W (1951) A statistical distribution function of wide applicability. J Appl Mech 18:293-297

Wipfler P, Seifert T, Biber P, Pretzsch H (2009) Intra-annual growth response of adult Norway spruce (Picea abies [L.] KARST.) and European beech (Fagus sylvatica $\mathbf{L}$.) to an experimentally enhanced, free-air ozone regime. Eur J For Res 128:135-144. https://doi.org/10.1007/s10342-008-0255-1

Yang RC, Kozak A, Smith JHG (1978) The potential of Weibull-type functions as flexible growth curves. Can J For Res 8:424-431. https://doi.org/10.1139/x 78-062

Zang C, Hartl-Meier C, Dittmar C, Rothe A, Menzel A (2014) Patterns of drought tolerance in major European temperate forest trees: climatic drivers and levels of variability. Global Change Biol 20:3767-3779. https://doi.org/10.1111/gcb.12637

Zeide B (1985) Tolerance and self-tolerance of trees. Forest Ecol Manag 13:149-166. https://doi.org/10.1016/03781127(85)90031-3

Zhai L, Bergeron Y, Huang J-G, Berninger F (2012) Variation in intraannual wood formation, and foliage and shoot development of three major Canadian boreal tree species. Am J Bot 99:827-837. https://doi.org/10.3732/ajb.1100235

Zweifel R, Häsler R (2001) Dynamics of water storage in mature subalpine Picea abies: temporal and spatial patterns of change in stem radius. Tree Physiol 21:561-569

Publisher's Note Springer Nature remains neutral with regard to jurisdictional claims in published maps and institutional affiliations. 


\section{Supplementary material}
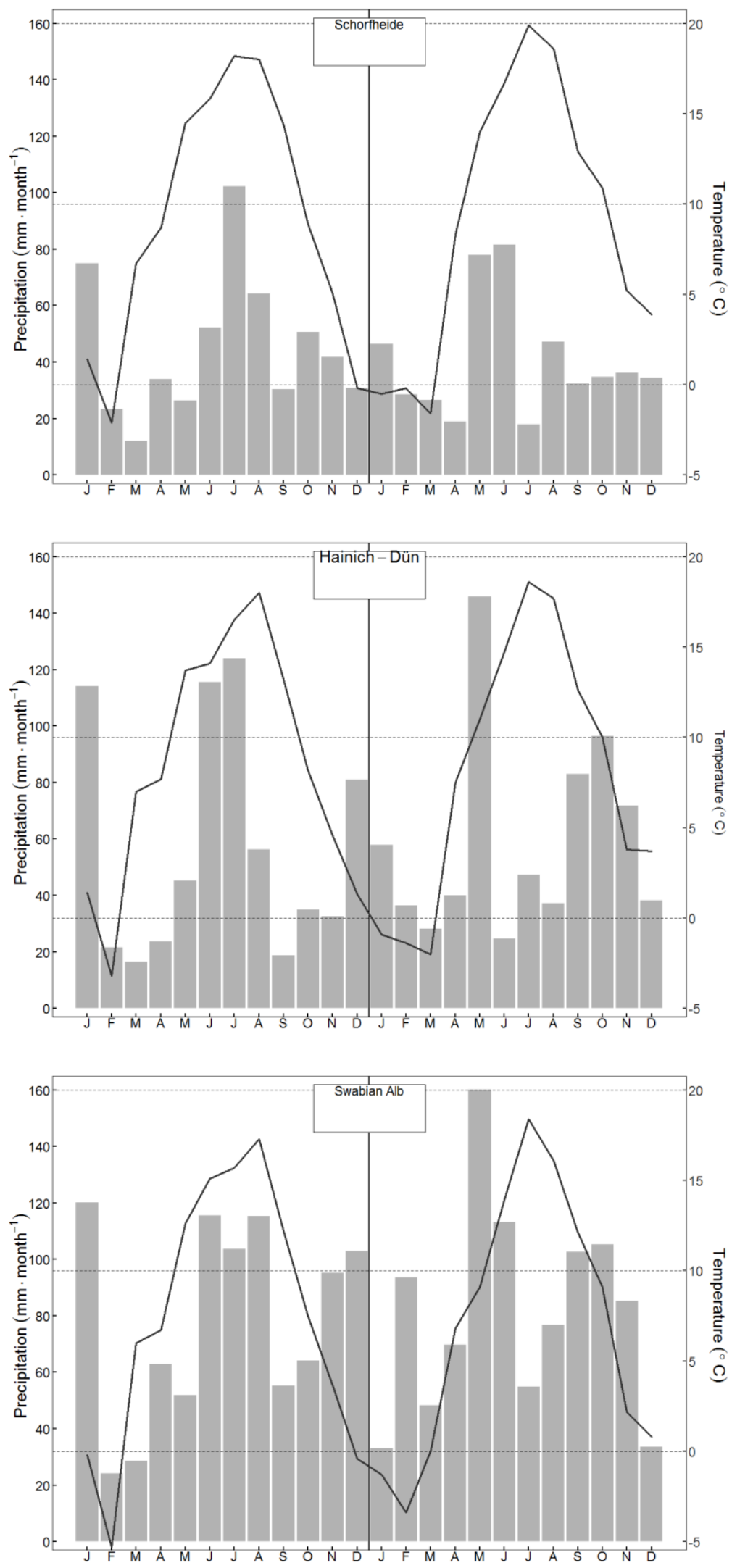

Fig. S1 Monthly mean precipitation sums (bar plots) and monthly mean air temperatures (line graphs) during both years under investigation (2012-2013). 


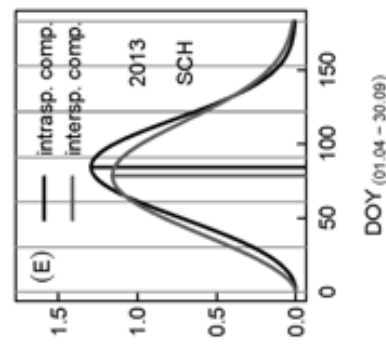

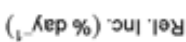

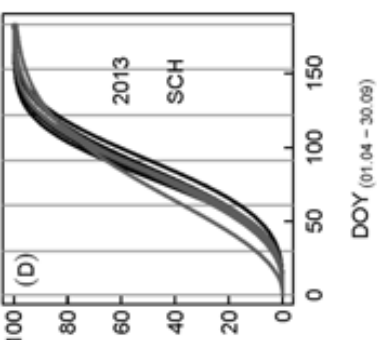

(\%) 'ou ' ’oy

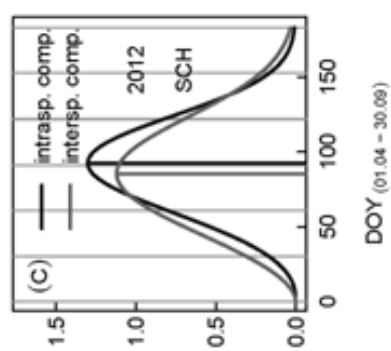

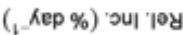

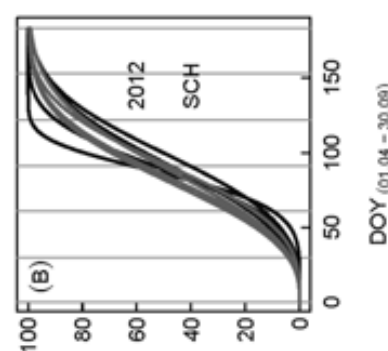

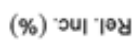

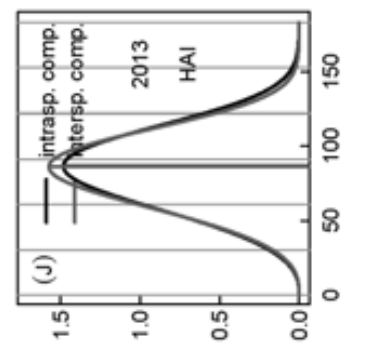

(1_-Kep \%) 'oul 'ןy

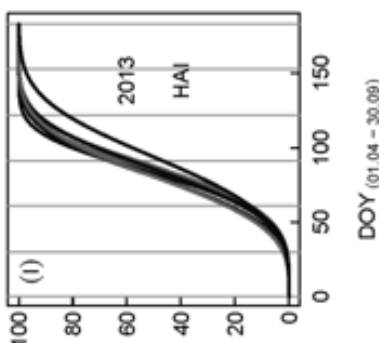

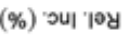
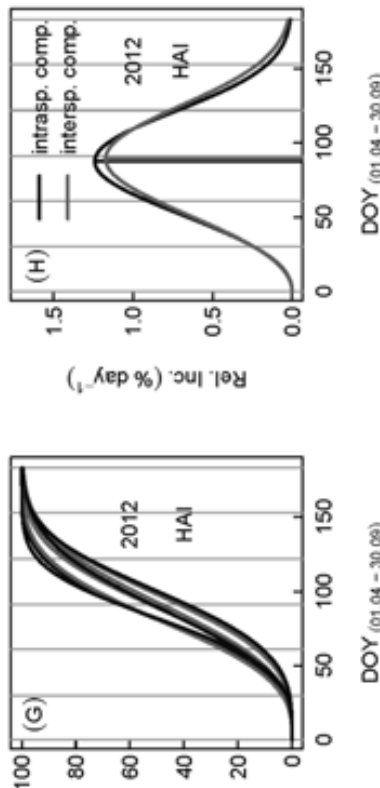

(\%) 'uㅣ ' 'ә⿻⽊

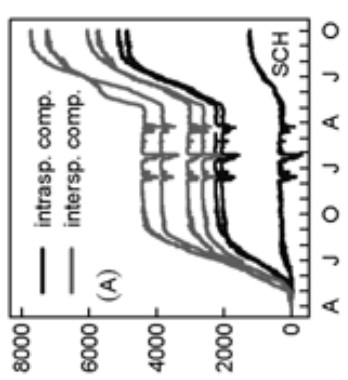

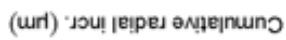

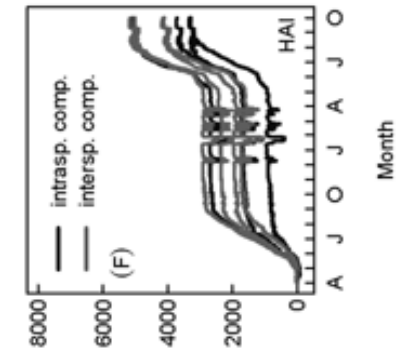

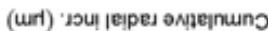

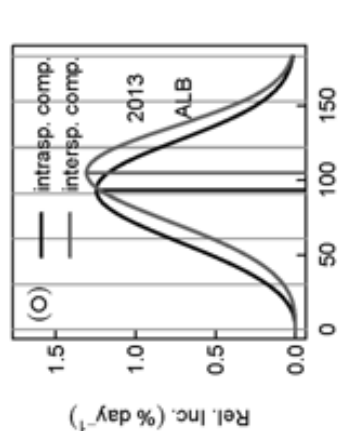

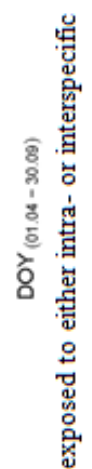

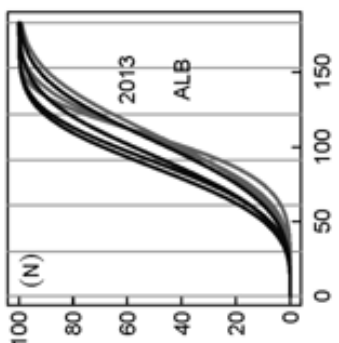

(\%) 'vu "10y
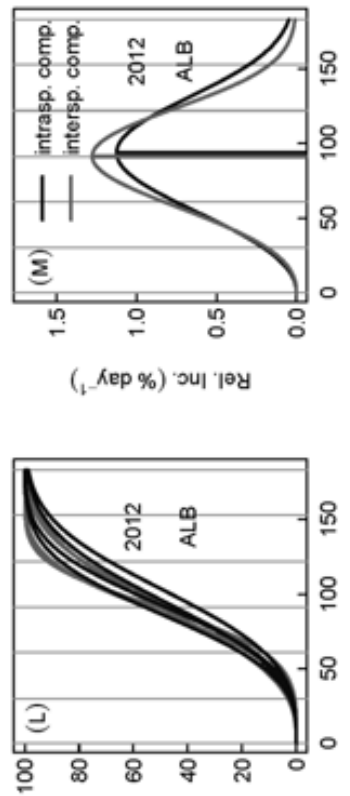

(\%) 'vu 'ю्य

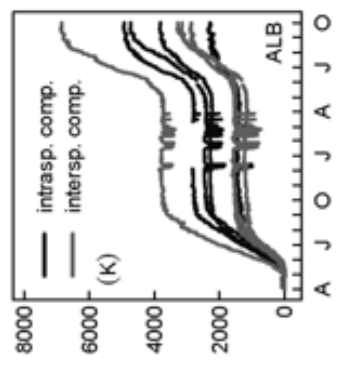

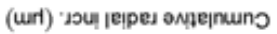



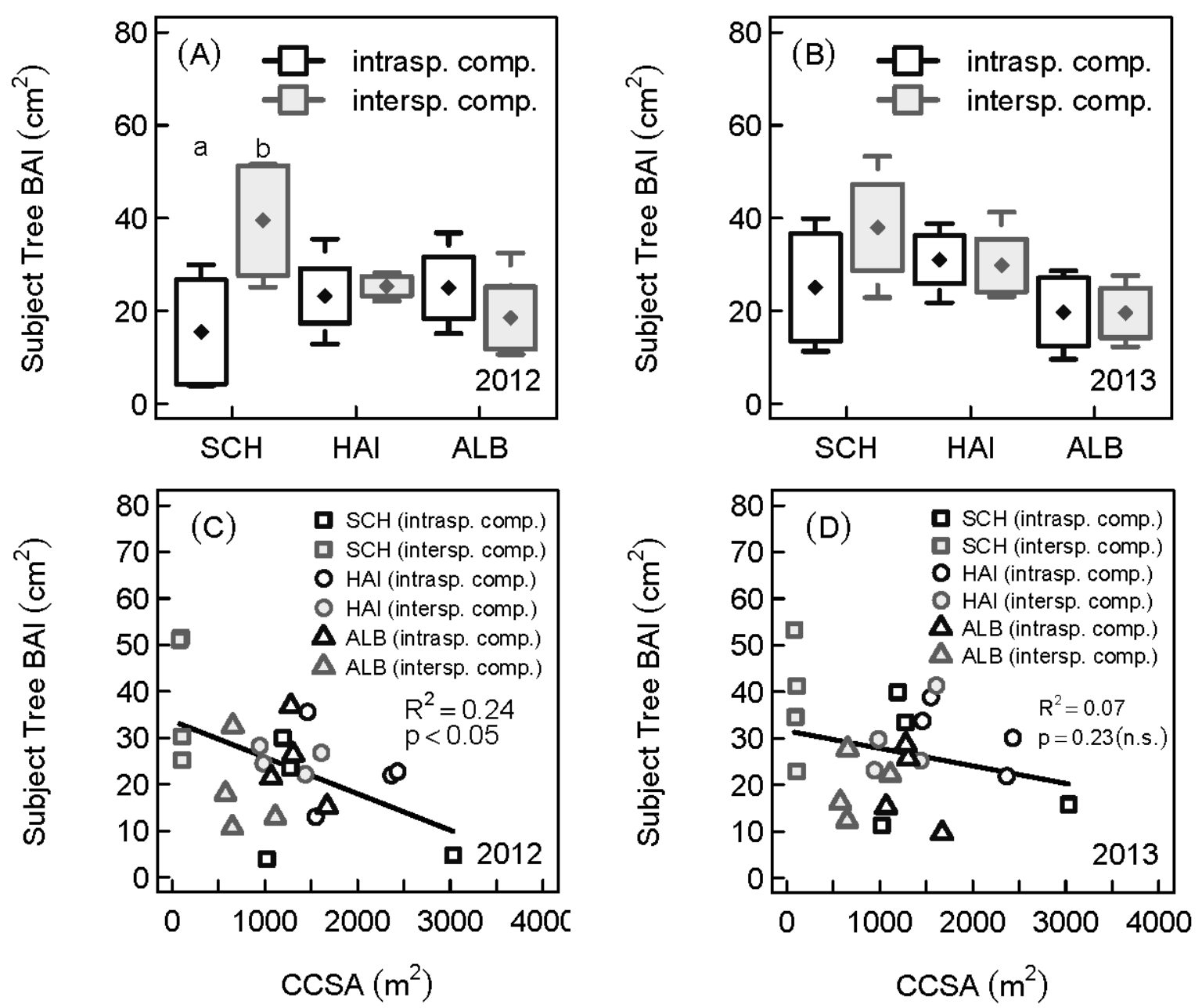

Fig. S3 Absolute basal area increment of subject trees being exposed to either intra- or interspecific competition (top) as well as impact of competition intensity (CCSA) on absolute BAI of the subject trees (bottom). Different letters above the box-whisker-plots indicate significant differences between mean BAI $\left(\mathrm{cm}^{2}\right)$ of beeches from pure and mixed stands of the same Exploratory (npar.t.test: $\mathrm{p} \leq 0.05$ ).

At the Exploratory Swabian Alb and with regard to 2013 also in the Hainich-Dün region, comparisons of absolute increment rates $\left(\right.$ in $\mathrm{cm}^{2}$ ) differ from results for relative basal area growth (in \%). This is due to the fact that the average starting dbh (Table 2) of the subject trees from pure beech stands there were larger (HAI: $45.05 \mathrm{~cm}$; ALB: $35.35 \mathrm{~cm}$ ) than the reference values from groups with interspecific competition (HAI: $38.68 \mathrm{~cm}$; ALB: 30.56 $\mathrm{cm}$ ), what could not be compensated by higher percentage growth rates. 


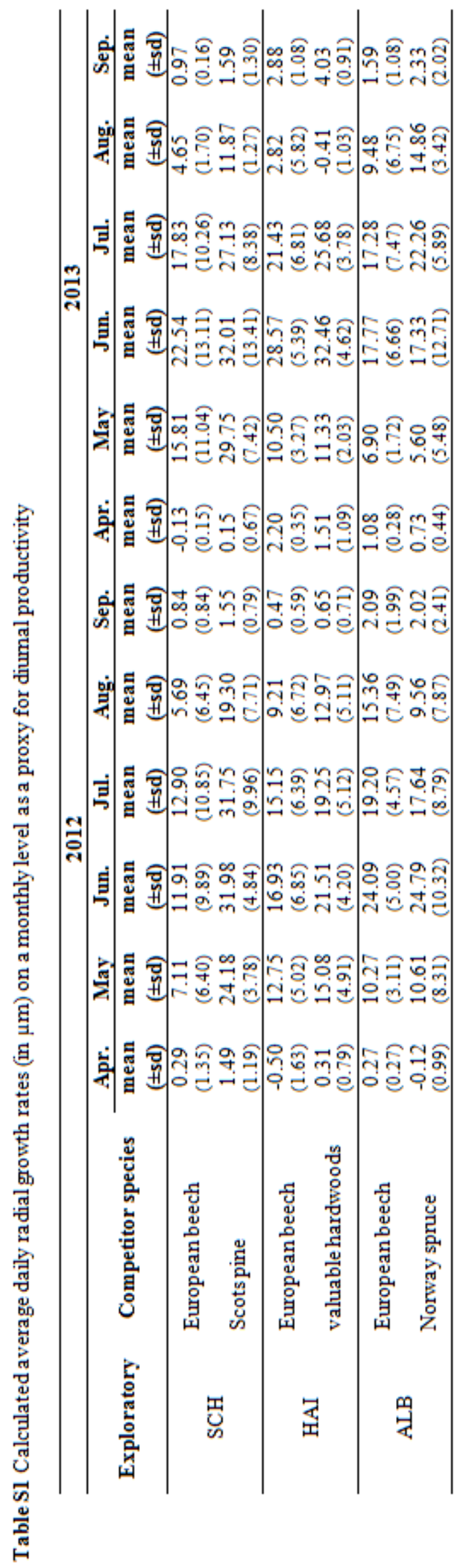


Table S2 Monthly mean air temperatures $\left[{ }^{\circ} \mathrm{C}\right]$ and monthly precipitation sums $[\mathrm{mm}]$ during both years under investigation (2012-2013).

\begin{tabular}{|c|c|c|c|c|c|c|}
\hline & \multicolumn{6}{|c|}{ mean monthly air temperatures $\left[{ }^{\circ} \mathrm{C}\right]$} \\
\hline & \multicolumn{3}{|c|}{2012} & \multicolumn{3}{|c|}{2013} \\
\hline month & SCH & HAI & ALB & $\mathbf{S C H}$ & HAI & ALB \\
\hline Jan & 1.4 & 1.4 & -0.2 & -0.5 & -0.9 & -1.3 \\
\hline Feb & -2.1 & -3.2 & -5.3 & -0.2 & -1.4 & -3.4 \\
\hline Mar & 6.7 & 7.0 & 6.0 & -1.6 & -2.0 & 0.0 \\
\hline Apr & 8.7 & 7.7 & 6.7 & 8.3 & 7.5 & 6.8 \\
\hline May & 14.5 & 13.7 & 12.6 & 14.0 & 11.0 & 9.1 \\
\hline Jun & 15.8 & 14.1 & 15.1 & 16.7 & 14.7 & 13.9 \\
\hline Jul & 18.2 & 16.5 & 15.7 & 19.9 & 18.6 & 18.4 \\
\hline Aug & 18.0 & 18.0 & 17.3 & 18.6 & 17.7 & 16.1 \\
\hline Sep & 14.4 & 13.2 & 12.2 & 12.9 & 12.6 & 12.1 \\
\hline Oct & 8.9 & 8.2 & 7.5 & 10.9 & 10.0 & 9.1 \\
\hline Nov & 5.1 & 4.6 & 3.7 & 5.2 & 3.8 & 2.2 \\
\hline \multirow[t]{3}{*}{ Dec } & -0.2 & 1.3 & -0.4 & 3.9 & 3.7 & 0.8 \\
\hline & \multicolumn{6}{|c|}{ monthly precipitation sums [mm] } \\
\hline & \multicolumn{3}{|c|}{2012} & \multicolumn{3}{|c|}{2013} \\
\hline month & SCH & HAI & ALB & SCH & HAI & ALB \\
\hline Jan & 74.9 & 114.1 & 120.1 & 46.4 & 57.9 & 32.9 \\
\hline Feb & 23.3 & 21.5 & 24.1 & 28.5 & 36.4 & 93.6 \\
\hline Mar & 12.1 & 16.6 & 28.5 & 26.6 & 28.1 & 48.3 \\
\hline Apr & 34.0 & 23.8 & 62.9 & 19.0 & 40.1 & 69.7 \\
\hline May & 26.3 & 45.2 & 51.8 & 78.0 & 145.9 & 160.2 \\
\hline Jun & 52.3 & 115.6 & 115.6 & 81.6 & 24.8 & 113.2 \\
\hline Jul & 102.3 & 123.9 & 103.6 & 18.0 & 47.2 & 54.8 \\
\hline Aug & 64.4 & 56.2 & 115.4 & 47.3 & 37.1 & 76.7 \\
\hline Sep & 30.4 & 18.7 & 55.3 & 32.4 & 82.9 & 102.6 \\
\hline Oct & 50.6 & 35.0 & 64.2 & 34.8 & 96.5 & 105.3 \\
\hline Nov & 41.8 & 32.5 & 95.3 & 36.2 & 71.8 & 85.2 \\
\hline Dec & 30.7 & 80.9 & 102.9 & 34.4 & 38.2 & 33.5 \\
\hline
\end{tabular}


Table S3 (inverse) Weibull parameter function values

\begin{tabular}{|c|c|c|c|c|c|c|c|c|}
\hline \multirow{4}{*}{$\begin{array}{c}\text { Exploratory } \\
\text { year } \\
\text { competitor species } \\
\end{array}$} & \multicolumn{8}{|c|}{ Schorfheide-Chorin } \\
\hline & \multicolumn{4}{|c|}{2012} & \multicolumn{4}{|c|}{2013} \\
\hline & \multicolumn{2}{|c|}{ European beech } & \multicolumn{2}{|c|}{ Scots pine } & \multicolumn{2}{|c|}{ European beech } & \multicolumn{2}{|c|}{ Scots pine } \\
\hline & mean & \pm SD & mean & \pm SD & mean & $\pm \mathrm{SD}$ & mean & \pm SD \\
\hline $\mathrm{T}(63 \%)$ & 101.96 & 8.75 & 99.52 & 4.93 & 95.20 & 5.62 & 92.75 & 3.05 \\
\hline $\mathbf{m}$ & 3.83 & 1.16 & 2.87 & 0.22 & 3.20 & 0.13 & 2.79 & 0.51 \\
\hline onset of wood formation (d) & 45 & 6.52 & 35 & 3.88 & 38 & 3.32 & 32 & 7.39 \\
\hline cessation of wood formation (d) & 139 & 21.38 & 146 & 6.70 & 134 & 7.04 & 139 & 7.88 \\
\hline duration of wood formation (d) & 94 & 27.10 & 111 & 6.79 & 96 & 4.77 & 107 & 15.17 \\
\hline r (coefficient of correlation) & 0.96 & 0.04 & 1.00 & 0.00 & 0.99 & 0.00 & 0.99 & 0.00 \\
\hline Exploratory & \multicolumn{8}{|c|}{ Hainich-Dün } \\
\hline year & \multicolumn{4}{|c|}{2012} & \multicolumn{4}{|c|}{2013} \\
\hline competitor species & \multicolumn{2}{|c|}{ European beech } & \multicolumn{2}{|c|}{ valuable hardwoods } & \multicolumn{2}{|c|}{ European beech } & \multicolumn{2}{|c|}{ valuable hardwoods } \\
\hline & mean & \pm SD & mean & \pm SD & mean & \pm SD & mean & \pm SD \\
\hline $\mathrm{T}(63 \%)$ & 98.65 & 9.57 & 101.61 & 7.39 & 94.39 & 6.97 & 93.06 & 2.74 \\
\hline $\mathbf{m}$ & 3.30 & 0.33 & 3.10 & 0.19 & 3.86 & 0.42 & 3.87 & 0.30 \\
\hline onset of wood formation (d) & 40 & 6.01 & 39 & 4.81 & 43 & 2.59 & 43 & 3.73 \\
\hline cessation of wood formation (d) & 138 & 13.17 & 145 & 8.44 & 126 & 12.21 & 124 & 2.20 \\
\hline duration of wood formation (d) & 98 & 11.22 & 106 & 5.04 & 83 & 12.29 & 81 & 3.89 \\
\hline $\mathbf{r}$ (coefficient of correlation) & 0.99 & 0.01 & 0.98 & 0.01 & 0.98 & 0.01 & 0.98 & 0.00 \\
\hline Exploratory & \multicolumn{8}{|c|}{ Swabian Alb } \\
\hline year & \multicolumn{4}{|c|}{2012} & \multicolumn{4}{|c|}{2013} \\
\hline competitor species & \multicolumn{2}{|c|}{ European beech } & \multicolumn{2}{|c|}{ Norway spruce } & \multicolumn{2}{|c|}{ European beech } & \multicolumn{2}{|c|}{ Norway spruce } \\
\hline & mean & \pm SD & mean & \pm SD & mean & \pm SD & mean & \pm SD \\
\hline $\mathrm{T}(63 \%)$ & 106.57 & 7.98 & 101.62 & 4.54 & 103.72 & 8.57 & 113.38 & 6.45 \\
\hline $\mathbf{m}$ & 3.16 & 0.16 & 3.46 & 0.64 & 3.54 & 0.13 & 4.12 & 0.88 \\
\hline onset of wood formation (d) & 42 & 3.51 & 42 & 5.64 & 45 & 3.74 & 54 & 9.24 \\
\hline cessation of wood formation (d) & 151 & 11.94 & 141 & 13.53 & 142 & 12.02 & 149 & 9.79 \\
\hline duration of wood formation (d) & 109 & 9.94 & 99 & 18.51 & 97 & 8.92 & 95 & 15.25 \\
\hline r (coefficient of correlation) & 0.99 & 0.00 & 0.98 & 0.01 & 0.99 & 0.00 & 0.98 & 0.02 \\
\hline
\end{tabular}




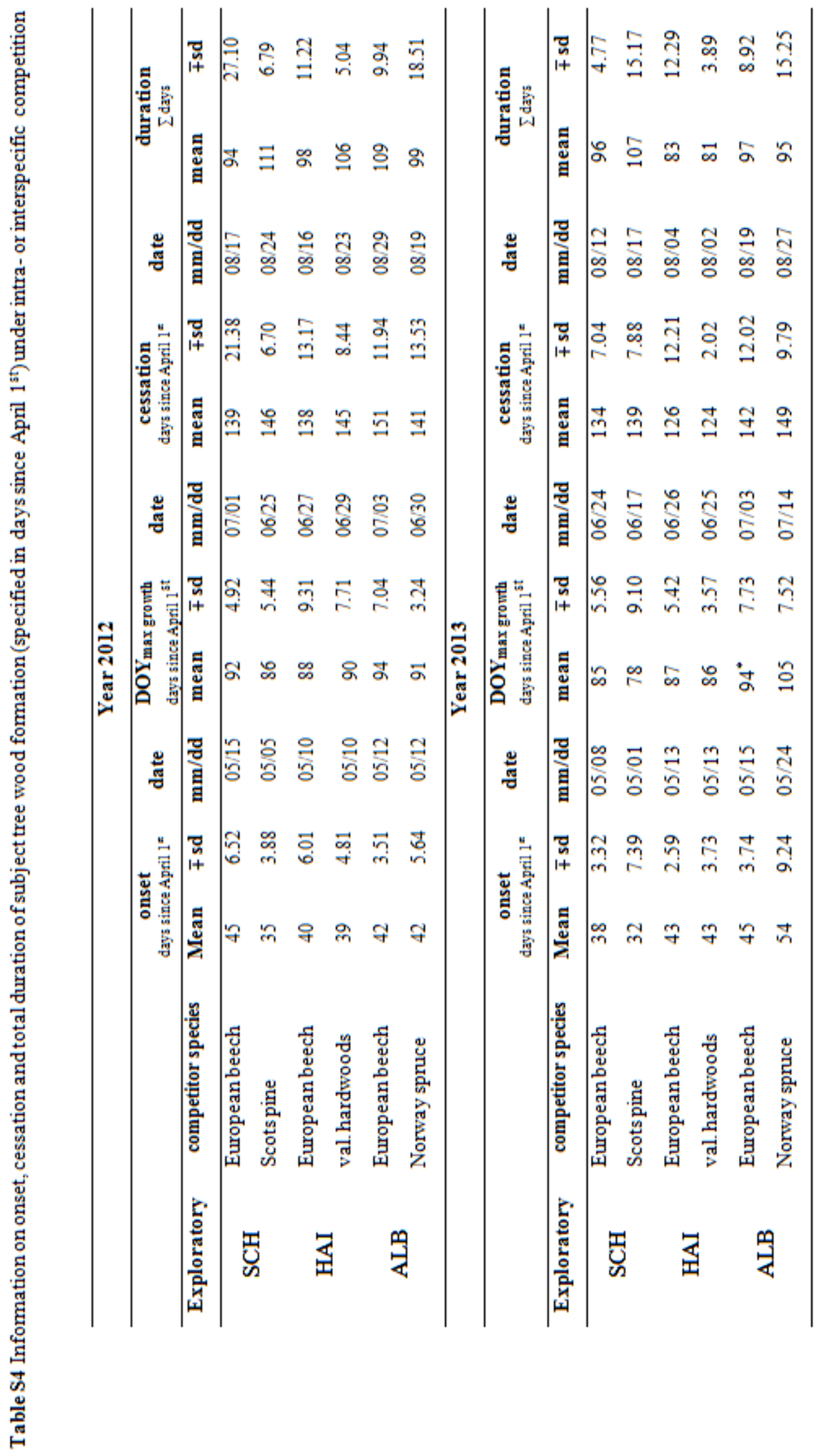


Chapter 5

Synthesis 


\section{Synthesis}

The synthesis section intends not only to recapitulate and to discuss the findings of the three included studies but aims to evaluate the implementation of the main dissertation objectives that were introductorily defined as follows:

a) to measure the impact of competition intensity and neighborhood identity on stem growth patterns of beech target trees at various time scales (day to year)

b) to explain the revealed growth response of selected beech target trees as a function of their competitive neighborhood

c) to explain the revealed growth pattern by analyzing growth related ecophysiological and morphological plant traits such as stable isotope ratios or crown architecture

\subsection{Methodical considerations}

By intensively investigating growth responses and plant traits of individual beech target trees as a function of their local competitive environment, this study can contribute to better understand the influence of biodiversity (in terms of neighborhood identity) and management intensity on ecosystem functioning, which is one key objective of the Biodiversity Exploratories. However, as species richness and neighborhood composition may affect growth at different scales (Grossman et al. 2017; Ammer 2019), the results presented in this study that were obtained from single trees cannot simply be transferred to predict over- or underyielding effects at the stand level (cf. Mölder and Leuschner 2014).

Furthermore, the availability of only one mixture type per site made it impossible to test all four hypotheses across sites. Although it would have been the perfect study design, due to the following restrictions it was not feasible to investigate each mixture type in every Exploratory: At the Schorfheide-Chorin area, valuable hardwoods would not grow sufficiently well enough due to the poor soil conditions and are therefore not cultivated. Furthermore, in this extremely dry region, the establishment of Norway spruce (mixed) stands was already stopped decades ago because of their high vulnerability to bark beetle calamities. On the (much) better soils in the Exploratories Hainich-Dün and Swabian Alb, Scots pine is not managed extensively because it would need constant support to reduce competition by other species. However, even the site by site comparisons are of high scientific and practical value as reasonable mixture types frequently used at the given sites were examined. 


\subsection{Comments on main hypothesis number 1: One year basal area growth of target tree beeches does not depend on the magnitude of neighborhood competition they are exposed to}

In case of equal neighborhood density, the competition indices KKL and $\mathrm{CCSA}_{(\text {Cone) }}$ assessed aboveground intra-specific competition beech target trees had to cope with to be stronger than interspecific competition ascribed to valuable hardwoods, spruce or pine (cf. Metz et al. 2013). However, all-pairs comparisons yielded consistently significant differences only between the competitive strength of the neighboring species European beech, Norway spruce, and Scots pine (Metz et al. 2013). Significant negative correlations between the TLS-based competition indices and absolute one-year basal area increment generally attested that increasing competition lead to declining annual growth rates (Metz et al. 2013). This result was confirmed by the application of linear mixed effects regression models. Full models described the functional relationship between growth (response variable) and competition indices, initial dbh as well as site (predictor variables). The latter was incorporated as random effect whereas competition, initial size and their interactions were specified as fixed effect terms. It was shown, that the impact of competition on absolute basal area growth diminished with increasing initial dbh of the target tree (Metz et al. 2013). Furthermore linear regression modeling approximated a significant negative relationship between the TLS-derived competition index 'CCSA' and relative basal area growth rates in 2012 as well as 2013 (Metz et al. 2019). The symbol types used for the scatter plot illustrated, that compared to monospecific neighborhoods, interspecific competitive pressure exerted by valuable hardwoods, spruce or pine was lower and that neighborhood identity seemed to (co-) determine target tree growth response (chap. 4: Fig. 4). These findings lead to the conclusion, that hypothesis number one has to be rejected. When pooling data from all Exploratories, annual target tree basal area growth was significantly related to competition intensity (chap. 2: Fig. 8 and Appendix C; chap. 4: Fig. 4). 


\subsection{Comments on main hypothesis number 2: (Intra-annual) basal area or radial growth} of target tree beeches measured at different spatial scales and temporal resolutions does not depend on neighborhood identity (intra- versus inter-specific competition)

\subsubsection{Long-term tree-ring widths and one year basal area growth}

Long-term tree-ring widths of target trees exposed to interspecific competition and their relative one year basal area growth at the end of the vegetation periods 2012 and 2013 were higher than the corresponding values of beech trees in pure stands, even if the differences were not always statistically significant (Table 5.1). This applied to multiple comparisons across Exploratories and to pair-wise comparisons within the same study sites (Metz et al. 2013, 2016 and 2019).

Table 5.1: Summary on pair-wise tests (within Exploratories) and all-pairs comparisons (across Exploratories) between target tree subpopulations that were exposed to either intra- or interspecific competition.

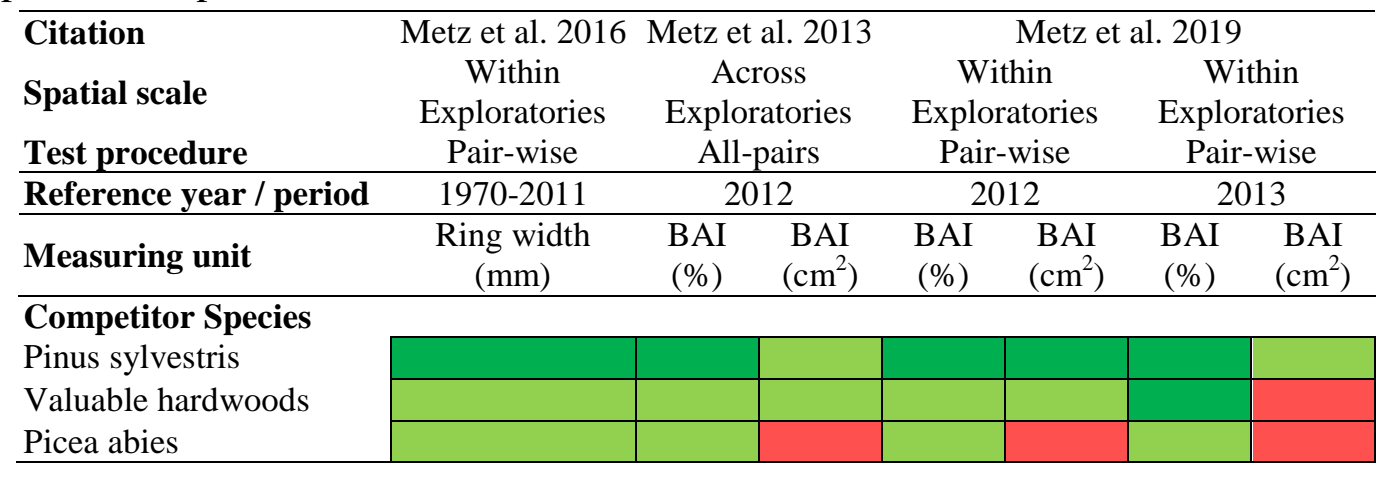

$=$ significant superiority of target tree beeches in groups of interspecific competition
$=$ insignificant superiority of target tree beeches in groups of interspecific competition
$=$ significant superiority of target tree beeches in groups of intraspecific competition
$=$ insignificant superiority of target tree beeches in groups of intraspecific competition

With regard to interspecific competition, one year relative basal area growth rates of the target tree beeches and their mean ring-widths for the period 1970-2011 were inversely related to the competition pressure ascribed to the competitor tree species (Metz et al. 2013, 2016 and 2019). Thus, highest (relative) target tree growth rates were consistently achieved in the neighborhood of Scots pine, whereas growth performance and competition reduction or facilitation effects in mixture with spruce and valuable hardwoods were (significantly) weaker (Metz et al. 2013, 2016 and 2019). The lower absolute basal area growth of beeches from the Swabian Alb mixed stands at the end of vegetation periods 2012 and 2013 was mainly due to their smaller initial dbh $(\overline{\mathrm{x}}=30.56 \mathrm{~cm})$ in relation to the reference values calculated for target trees with intraspecific competitive neighborhoods (Alb: $\overline{\mathrm{x}}=35.35 \mathrm{~cm}$; all Explos: $\overline{\mathrm{x}}=$ 
$41.00 \mathrm{~cm}$ ). To prevent confounding impacts of deviating target tree dbh on data analysis, comparisons of basal area increment were primarily carried out on the basis of relative growth rates (Metz et al. 2013, 2019). It is also important, that within the same Exploratory, the sizeratio of mean target tree dbh to mean competitor tree dbh was similar in groups of intra- and interspecific competition (Metz et al. 2016).

\subsubsection{Intra-annual growth dynamics}

The analysis of intra-annual growth dynamics has shown that only in the Schorfheide-Chorin mixed stands, temporal niche partitioning can be considered as a possible co-factor that may have caused the observed (relative) growth superiority of beeches exposed to interspecific competition (Metz et al. 2019). Wood formation of target trees in the neighborhood of Scots pines $(\mathrm{SCH})$ began and peaked earlier but ended later (chap. 4: Figs. 5 and 6) than in pure stands of the same region whereas competitive neighborhoods consisting of valuable hardwoods (HAI) or spruce (ALB) did not trigger general trends towards extended growth durations of beech target trees (chap. 4: Figs. 5 and 6). In all Exploratories, average daily radial growth rates (in $\mu \mathrm{m}$ ) of target tree beeches (monthly resolution) from pure und mixed stands of the same region run parallel to each other (chap. 4: Fig. 7). But at the Hainich-Dün and Swabian Alb sites, the growth promoting effect of allospecific competitive environments on daily stem growth rates was considerably weaker than in the Schorfheide-Chorin area. These findings suggest that at a given site, the investigated interspecific neighborhoods can initiate increased daily growth rates during certain periods of the growing season, but positive species interactions are too weak to uncouple fundamental growth-environment responses of European beech (Mölder and Leuschner 2014; Metz et al. 2019).

Testing of hypothesis number two is subject to some statistical limitations due to the selected experimental design (cf. chapter 1.3) that intends to detect different patterns of growthneighborhood responses at the individual tree level and therefore requires competitive environments of equal density (Ammer 2019) and comparable tree dimension but different species identity. First, for a clear distinction between the effects of species identity and competition intensity, trees surrounded by neighbors differing in species but of equal competitive power would have been needed. However, such stand conditions were impossible to find. As a result, it could not be finally ascertained whether or not the observed growth responses were caused by species identity per se or by the different competitive strength inherent to the different tree species. Second, intrinsic adverse characteristics of (numerous) 
studies that are based on dendrochemical or dendrometric measurements are comparatively small sample sizes (cf. Wipfler et al. 2009; Mölder et al. 2011; Michelot et al. 2012; Oberhuber et al. 2014) as well as short periods under investigation. Consequently, statistical testing is subject to methodical restrictions and evidence for significance hard to provide (Metz et al. 2016). Nevertheless, data analysis revealed that within the same Exploratory, reduced competition intensity associated with interspecific neighborhoods entailed (significantly) higher mean radial increment over a 41 -year period and increased relative basal area growth rates at the end of growing seasons 2012 as well as 2013. Referring to these clear trends towards superior long-term growth performance and total annual growth during two years with normal weather conditions, null hypothesis number two can be rejected. With regard to intra-annual radial growth patterns, null hypothesis number two can be rejected only for target trees surrounded either by conspecifics or Scots pine at the Exploratory Schorfheide-Chorin (Metz et al. 2019). 


\subsubsection{Drought-induced reactions of radial beech growth}

Table 5.2: Summary on pair-wise tests between target tree subpopulations of the same Exploratory that were exposed to either intra- or interspecific competition.

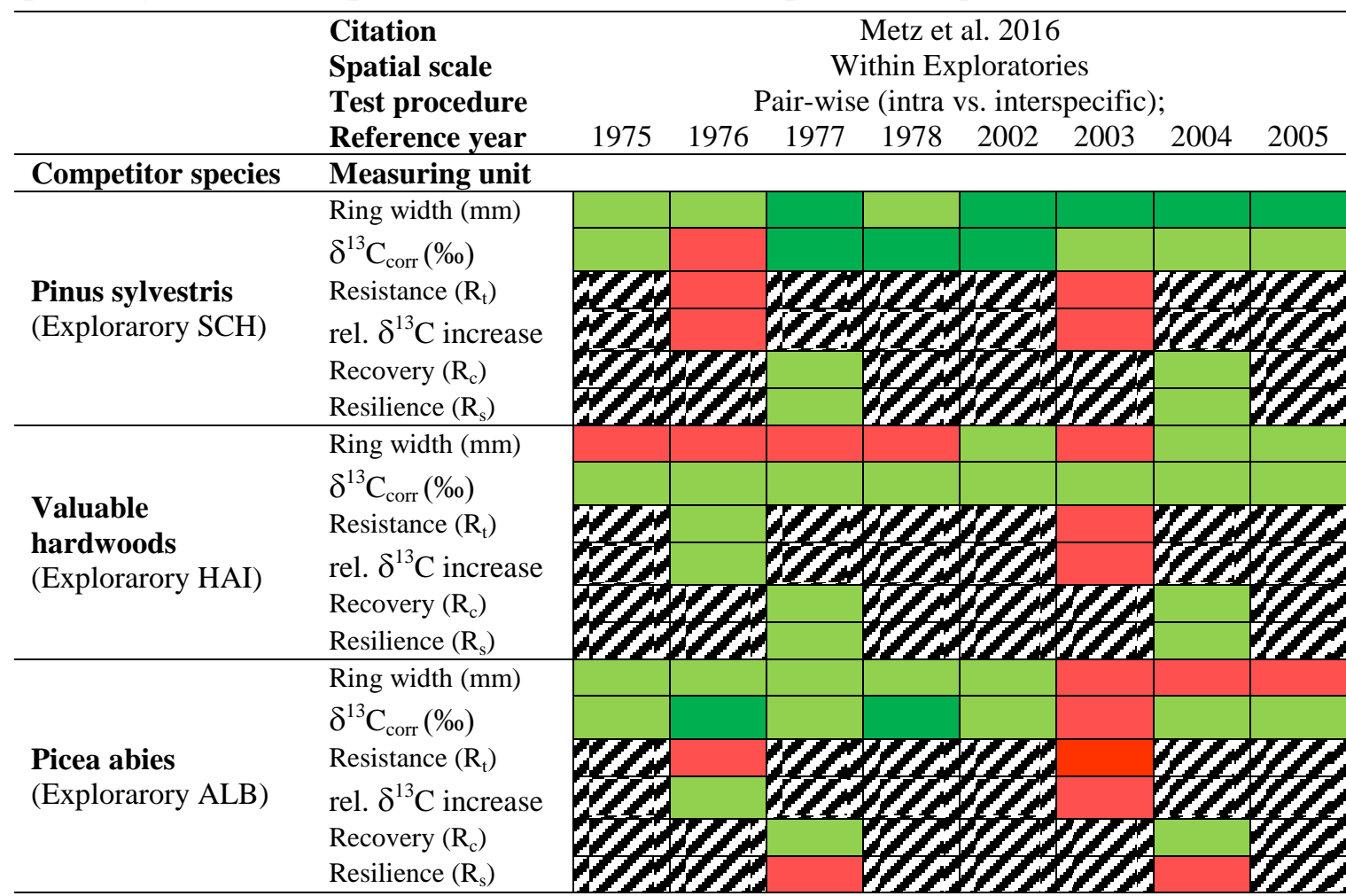

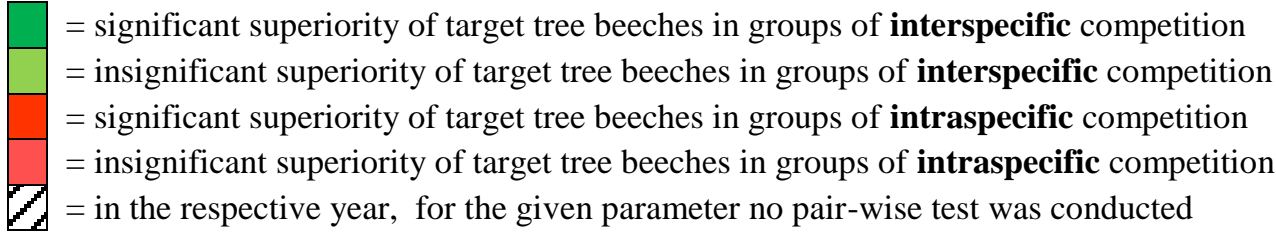

Detailed analysis of 4-year periods that included the drought years 1976 and 2003 generally confirmed the long-term growth trends for the period 1970-2011 (Metz et al. 2016). However, as illustrated in table 5.2, within the same Exploratory reduced competition intensity associated with interspecific neighborhoods did not consistently promote higher absolute radial beech growth rates. Only in mixture with Scots pine $(\mathrm{SCH})$, target trees achieved (significantly) higher mean ring-widths without exception. At the Exploratories HAI and ALB, pair-wise comparisons for the years 1975-1978 and 2002-2005 yielded inconsistent results. This indicates that under the prevailing local growing conditions, the effects of Norway spruce (ALB) and valuable hardwoods (HAI) on target tree growth were less pronounced. The resistance index $\left(\mathrm{R}_{\mathrm{t}}\right)$ pointed to the conclusion, that within the same investigation area, the relative reduction of standardized radial increment induced by the exceptional dry years 1976 and 2003 was more pronounced in mixed beech stands than growth depression of target trees exposed to intraspecific competition. In contrast to relative 
growth depression, site-by-site comparisons revealed that within all Exploratories, postdrought recovery $\left(R_{c}\right)$ of stem increment was (insignificantly) lower in groups of intraspecific competition than in mixed stands of the same region. This applies accordingly to the mean resilience index values $\left(\mathrm{R}_{\mathrm{s}}\right)$, apart from the Exploratory Swabian Alb (Metz et al. 2016). The results summarized in table 5.2 indicate, that within the same Exploratory, during exceptional dry years reduced competition intensity associated with interspecific neighborhoods did not always promote higher absolute stem increment rates. Besides that, release from more intense intraspecific competition seemed to have a positive impact on postdrought growth recovery (and resilience) of target tree beeches, irrespective of competitor tree species and investigation area.

Summing up, pertaining to short-term drought response, main hypothesis number two can only be partly rejected. On the one hand, stress reaction pattern of beech target trees seemed to differ considerably as a function of neighborhood identity and (weather-induced) ringwidth variability across sites. Due to the availability of only one mixture type per Exploratory, unjustified generalizations across sites must be avoided. On the other hand, information derived from absolute radial growth rates and index values for drought-related growth depression $\left(R_{t}\right)$, recovery $\left(R_{c}\right)$ or resilience $\left(R_{s}\right)$ must not be consistent, what implies a certain risk for misinterpretations of stress reaction pattern. This means, that in the dry respectively the postdrought year, actual ring-widths of target trees exposed to interspecific competition can be wider or smaller, although relative reduction $\left(R_{t}\right)$ or recovery $\left(R_{c}\right)$ of standardized radial increment point towards stronger or weaker growth response.

\subsection{Comments on main hypothesis number 3: There is no difference in wood $\delta^{13} \mathrm{C}$ - values of target tree beeches regardless of competition intensity and neighborhood identity}

The indices KKL and CCSA that consider species identity of the surrounding trees indicate, that beech is exposed to stronger (aboveground) competition in intraspecific neighborhoods than in interspecific surroundings (Metz et al. 2013). Nevertheless, within the same study area, the impact of neighborhood identity on water stress-related relative increase in $\delta^{13} \mathrm{C}$ during exceptional drought was weak (cf. chap. 3: Figs 7a and 8a). The only exception was the strong wood carbon isotopic response of target tree beeches with Scots pines as competitor trees to the dry year 2003. However, for several reasons measurements of tree-ring stable isotopes generally point to higher drought stress levels or reduced water-use efficiency due to more intense intraspecific (root) competition (Metz et 


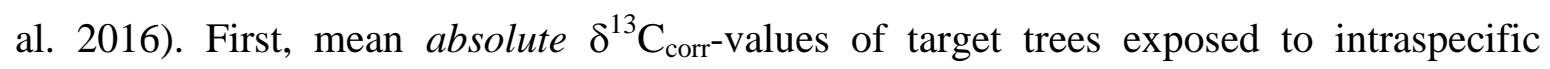
competition were almost invariably (but only in some cases significantly) higher compared to stable isotope ratios of beeches from mixed stands of the same Exploratory (cf. Table 5.2; chap. 3: Figs. 4 and 5). Second, multiple linear regression revealed a close across-site relationship between competition intensity and wood $\delta^{13} \mathrm{C}$-values (chap. 3: Fig. 6). Thus, even if the neighborhood identity effect could not be separated from the effect of competitive pressure per se, initial null hypothesis number three has to be rejected.

\subsection{Comments on main hypothesis number 4: There is no relationship between plant traits (e.g. wood $\delta^{13} \mathrm{C}$-values, crown surface areas) of target tree beeches and their radial or basal area stem growth}

Correlation analysis showed a (strong) negative relationship between ring widths and $\delta^{13} \mathrm{C}$ values of numerous trees (Supplementary material chap. 3; Table S1). These findings indicate, that during 4-year periods which comprise the low-precipitation pointer years 1976 and 2003, target trees with competitive neighborhoods consisting of regionally typical mixed species had to suffer under less severe drought stress than those in pure beech stands, causing later stomatal closure, lower wood stable isotope ratios and, in part, increased radial growth (cf. Metz et al. 2016). These results confirm the assessment of aboveground intra- and interspecific competition (Metz et al. 2013), suggest that with regard to the relationship between radial growth and wood stable isotope ratios, null hypothesis number four can also be rejected and support the conclusion that forest management as well as neighborhood composition may co-determine or even override the influence of climate conditions on wood $\delta^{13} \mathrm{C}$ signatures (Skomarkova et al. 2006; Mölder et al. 2011).

Contrary to initial expectations, no statistically significant relatiosnhip between (relative) basal area growth rates at the end of the growing seasons 2012 as well as 2013 and TLSderived crown surface areas (in $\mathrm{m}^{2}$ ) of the target tree beeches was found. Thus, referring to this morpholgical trait, our sample data failed to reject main hypothesis number 4. 


\subsection{Cause-and-effect relationships for obserevd growth responses and related plant traits}

To reveal how increasing tree species richness can (but must not inevitably) enhance stand productivity, Ammer (2019) presented a conceptual approach that combines some fundamental processes relaxation in mixtures is based on (cf. Fig. 5.1).

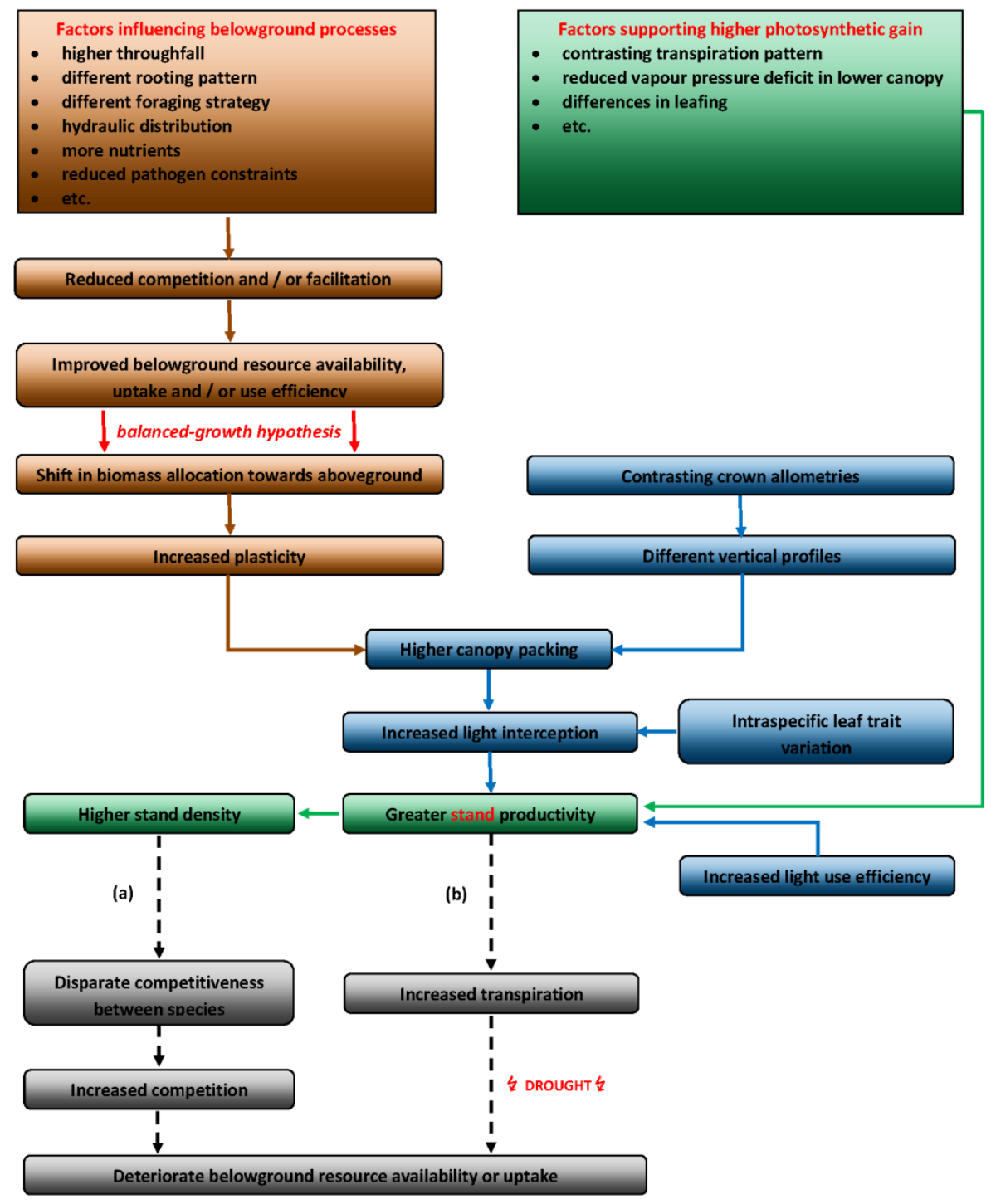

Fig. 5.1: Conceptual framework to explain the relationship between species diversity-related below- or aboveground relaxation and enhanced stand productivity. Bold arrows describe positive diversity-productivity interactions whereas dashed arrows refer to negative feedbacks associated with climate change (adopted from Ammer 2019 and adjusted).

The cause-effect diagram illustrates, that relaxation and subsequent stand productivity gains result from functional trait variation (complementarity) in multispecies forests and therefore from a multitude of processes that occur on manifold temporal or spatial resolutions (Ammer 2019). Despite of the aforementioned restrictions with regard to the transferability of stand- 
level data on individual trees or vice versa (cf. Mölder and Leuschner 2014), in the synthesis section, these explanatory approaches may serve as an orientation framework to integrate fundamental findings obtained from empirical investigations of the four introductorily formulated hypotheses (cf. chapters two to four) into an overall context.

\subsubsection{Belowground drivers for the observed growth responses and plant trait variations of European beech}

According to the concept illustrated in Fig. 5.1, improved belowground resource availability and resource use due to reduced competition or facilitation is regarded as initial requirement for greater productivity of species rich stands (Ammer 2019). But in mixed forests, morphological and ecophysiological characteristics of the species involved as well as site factors determine whether and to what extend soil resource availability, uptake or use efficiency may increase (Ammer 2019). As mechanisms to improve the tree nutritional status, Ammer (2019) mentions biological nitrogen fixation (Binkley 2003), higher decomposition rates or nutrient response efficiencies (Handa et al. 2014; Schmidt et al. 2015), base pumping by deep-rooted species (Berger et al. 2006), mycorrhizal symbiosis (Callaway 1995) or root diversity (Lang and Polle 2011). Especially during drought periods, enhanced water supply due to competition reduction or facilitation can be attained by decreased interception leading to increased stand precipitation (Schume et al. 2004), hydraulic lift as well as redistribution by deep rooting species (Zapater et al. 2011; Pretzsch et al. 2013b; Hafner et al. 2017) or improved water retention in the organic soil layers (Ilek et al. 2015) (direct effects). Vertical stratification of the rhizosphere and hence of soil water resources as well as divergent transpiration pattern (indirect effects) can also play a key role for improved belowground water availability, uptake or use (Schmid and Kazda 2001; Bolte and Villanueva 2006; Schwendenmann et al. 2015; Ammer 2019). However, as shall be elucidated later on, depending on the species mixture and local conditions, underlying processes for as well as the magnitude of improved belowground resource use can differ considerably.

In mixtures consisting of the complementary climax and early-successional species Fagus sylvatica and Pinus sylvestris several of these water-stress-releasing interactions may occur (González de Andrés et al. 2017). For example, higher amounts of throughfall (than in beech monocultures) seemed to have positive impacts on soil water availability and microclimate in groups of interspecific competition (Primicia et al. 2013). Furthermore, the root system of Fagus sylvatica L. was found to be very competitive and dynamic in mature 
mixed pine-beech forests (Curt and Prévosto 2003). In association with shallow-rooted Norway spruce too, belowground dominance and superior competitive ability of beech due to the occupation of deeper, less drought-susceptible soil layers as well as higher (fine) root abundance were observed (Schmid 2002; Schmid and Kazda 2002; Bolte and Villanueva 2006).

In contrast to this, studies conducted in mixed broad-leaved forests of the Hainich National Park could not provide any proof for higher fine root biomasses or more complementary spatial rooting patterns with increasing species richness. Instead, in the most diverse stands, the proportion of beech fine root biomass in soil samples was lower than its percentage share in total stand basal area (Meinen et al. 2009; Jacob et al. 2013). Thus, at the Hainich-Dün sites, differing seasonal stem growth dynamics and water use pattern between (diffuse- and ring-porous) tree species (Suzuki et al. 1996; Barbaroux and Bréda 2002; Gebauer et al. 2012; Köcher et al. 2009; Michelot et al. 2012), higher throughfall deposition rates (André et al. 2008), accelerated nutrient cycling and leaf litter decomposition (Jacob et al. 2009; Jacob et al. 2010b), increased nutrient input due to extended periods with interception capacity (Pretzsch et al. 2013a) or a more diverse mycorrhizal network (Lang 2008; Mölder and Leuschner 2014) may have had weaker positive effects on water and nutrient availability, uptake or use efficiency of beech target trees.

These findings on belowground processes can be linked to a consideration of Ammer (2019), who refers to the balanced-growth hypothesis (cf. Fig. 5.1). It implies that enhanced availability, uptake or use efficiency of belowground resources entail increasing aboveground biomass allocation (Shipley and Meziane 2002; Poorter et al. 2012). If this is the case, in multispecies stands, aboveground adaption of leaf area or crown characteristics and consequently enhanced productivity can occur (Forrester and Bauhus 2016; Ammer 2019). This was reflected by the TLS-derived crown surface areas $\left(\mathrm{CSA}_{\mathrm{TT}}\right)$ of the beech target trees. 


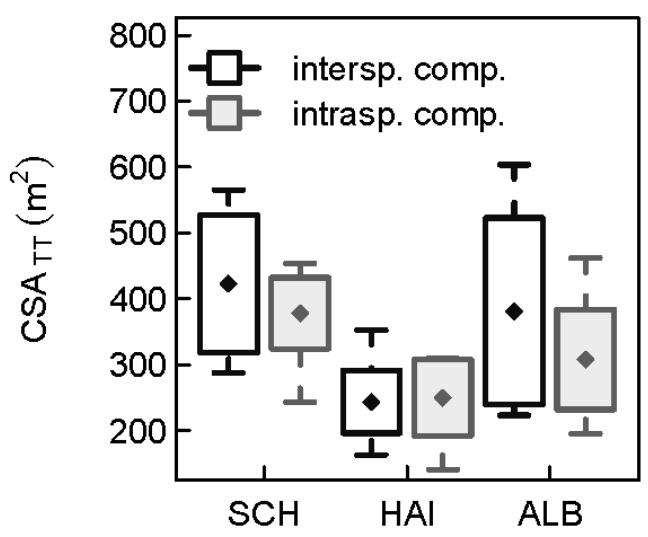

Fig. 5.2: TLS-derived crown surface areas of target tree beeches $\left(=\mathrm{CSA}_{\mathrm{TT}}\right)$ in spring 2012 in groups of either intra- or interspecific competition separately for each Exploratory (cf. Fig. S3 in Metz et al. 2016).

With exception of the Exploratory Hainich-Dün, internal comparisons show that mean crown surface areas of target trees $\left(\mathrm{CSA}_{\mathrm{TT}}\right)$ with interspecific neighborhoods which were exposed to lower (aboveground) competitive pressure are bigger ( $\mathrm{SCH}:+44.82 \mathrm{~m}^{2}, \mathrm{ALB}:+73.12 \mathrm{~m}^{2}$ ) than those of beeches growing in pure stands of the same area (cf. Metz et al. 2016). In absolute terms, target trees in the Schorfheide-Chorin area whose competitive neighborhood consisted of Scots pines developed the largest crown surface areas (Fig. 5.2) whereas at the Hainich-Dün sites, lacking belowground relaxation may have inhibited morphological adaptations of target tree crown size and hence space occupation in groups of interspecific competition (Forrester and Bauhus 2016; Ammer 2019). In interspecific neighborhoods, the magnitude of beech crown plasticity seems to depend on site fertility and species identity of the competitor trees (Dieler and Pretzsch 2013). It is known that increasing plasticity and unequal vertical profiles of different species in mixed stands result in higher canopy packing (Pretzsch 2014; Jucker et al. 2015). As the two latter characteristic traits of multi-species forests do mainly affect stand productivity, they were not subject of this work that focuses on the effect of neighborhood identity on the growth response of individual trees.

However, the stronger relative $\delta^{13} \mathrm{C}$ increase of target tree beeches whose competitive neighborhoods consisted of by Scots pine in response to the 2003 summer drought could also be linked to their strong morphological plasticity (Pretzsch 2014) and larger crown surface areas (Fig. 5.2). Stable isotope signatures indicated, that compared to beeches from pure stands of the Schorfheide-Chorin area, greater assimilation apparatus of target trees growing in mixture with Scots pine may have induced stronger reductions of stomatal conductance in order to decrease transpiration and water stress (cf. Metz et al. 2016). A similar finding was reported for spruce by Gebhardt et al. (2014). After thinning, transpiration of the remaining 
single trees increased, although stand-level transpiration decreased. Reviewing the interactions between species diversity and productivity of mixed stands, Ammer (2019) likewise refers to a possible negative feedback of increasing volume or biomass increment (cf. Fig. 5.1), denoted as disrupted complementarity effect: Higher stand productivity of mixed forests might lead to increasing water consumption and drought susceptibility of multispecies stands, if compensation by improved resource availability via facilitated uptake fails to appear (Kunert et al. 2012; Forrester 2015).

Two other approaches might help to explain, why at the Swabian Alb and Hainich-Dün sites, in some years, mean ring-widths of target trees exposed to interspecifc competition were smaller than in groups of intraspecific neighborhoods during the periods 1975-1978 and 20022005 (cf. Table 5.2): First, any increase in resource availability related to the admixture of a tree species might be counterbalanced, if that species consumes greater amounts of another resource. Consequently, superior growth performance is only triggered by competition reduction or facilitation, if these processes induce improved resource use (Ammer 2019). Second, according to the stress gradient hypothesis (Bertness and Callaway 1994), at the lowprecipitation Schorfheide-Chorin sites where sandy soils with limited water storage capacity prevail, stronger effects of competition reduction or facilitation can be expected than on the HAI and ALB sites with less intense belowground resource limitation. However, it seems as if tree species identity is of special importance when it comes to the effect of site conditions. Thus, the degree of improved belowground resource availability, uptake, or use efficiency may primarily be a function of species identity whereas site quality seems to be less important, though still relevant. For example, higher amounts of rainfall respectively more rarely occurring water stress episodes at the Swabian Alb sites and lacking root system complementarity in mixed broad-leaved forests of the Hainich-Dün region (Meinen et al. 2009; Jacob et al. 2013) may have entailed that in these Exploratories, growth-promoting effects as a consequence of belowground improvements were quite weak (Metz et al. 2016 and 2019). 


\subsubsection{Factors supporting higher photosynthetic gain as drivers for the observed growth response and plant trait variation}

In mixture with light-demanding Pinus sylvestris whose crowns are more diaphanous than those of shade-tolerant Fagus sylvatica (Ellenberg and Leuschner 2010), beech target trees may also have benefited from enhanced photosynthetic performance due to increased light absorption (Pretzsch et al. 2015). Furthermore, the pronounced growth superiority of target trees exclusively surrounded by Scots pine can be attributed to another aspect. Only in mixture with Scots pine, data analysis provided evidence for temporal niche differentiation whereas competitive neighborhoods consisting of valuable hardwoods or spruce did not alter intra-annual growth pattern of target tree beeches (Metz et al. 2019). This might be due to more favorable microclimatic conditions under mixed beech-pine canopies (Primicia et al. 2013) and related phenological adaptive responses. Compared to wood formation dynamics in pure stands of the Exploratory Schorfheide-Chorin, maybe earlier leaf unfolding and later leaf senescence of beech target trees exposed to interspecific competition by pine might have a prolonging effect on growing season length.

In mixture with spruce (ALB), factors that support higher photosynthetic gain (cf. upper right flowchart box of Fig. 5.1) may have been the primary drivers for the trend towards higher (relative) annual and multiyear growth rates of target tree beeches growing under interspecific competition (Metz et al. 2013, 2016 and 2019). In Picea abies-Fagus sylvatica mixtures, target trees might have benefited from aboveground competitive reduction (Pretzsch and Schütze 2009) due to different light ecology (Pretzsch et al. 2013a) as well as crown architecture of beech with its distinct potential for lateral or vertical expansion and more cone-shaped spruce (Pretzsch and Schütze 2005). On the other hand, in case of our target trees, access to and absorption of light might be impaired because at the Swabian Alb sites that are hallmarked by greatest amounts of rainfall, height increment of spruce competitors exceeded that of focal beeches (Pretzsch and Schütze 2009; chap. 3: Table 1 and chap. 4: Table 2). Furthermore, in mixture with spruce, biomass investment of beech tends to focus on space occupation and structural adaptation to asymmetric competition for light whereas efficiency in space exploitation decreases (Pretzsch and Schütze 2005 and 2009; Bayer and Pretzsch 2017). This suggests that under less intense interspecific competition in spruce neighborhoods, beech crown dimensions increased (cf. Fig. 5.2) while crown efficiency was not positively influenced (Pretzsch and Schütze 2009). This might be further reasons, why in the neighborhood of spruce, the enhancement of beech stem growth was 
lower than competition reduction predicted by the two competition indices KKL and $\operatorname{CCSA}_{(\text {Cone) }}$ indicated (Metz et al. 2016 and 2019). Furthermore, these results could provide an explanation for the missing relationship between one-year basal area increment and crown surface areas of the target trees. Obviously, morphological traits must be considered in conjunction with additional information on the competitive status or resource limitation of individual trees, in order to explain growth responses of individual trees. This is confirmed by the fact that target tree beeches from pure stands of the driest Exploratory Schorfheide-Chorin developed larger crowns than their conspecifics at the Swabian Alb or Hainich-Dün sites (Fig. 5.2), but did not achieve their long-term radial or one-year basal area growth rates (chap. 3: Fig. 1 and chap. 4: Fig. 4).

During the low-precipitation pointer years 1976 and 2003, additional mixture specific interdependencies that can provide further ecophysiological explanations for the observed drought-related growth pattern and signals in tree-ring stable isotope ratios may have come into effect. As indicated by lower wood $\delta^{13} \mathrm{C}$-values, different water-consumption strategies of beech and some of the admixed tree species may have caused reduced water stress levels in groups of interspecific competition. Isohydric species such as pine or shallow-rooted spruce react with earlier stomatal closure to water stress, in order to reduce transpiration and growth. This kind of 'prevention strategy' might have enhanced water availability for more anisohydric beech (Hartmann 2011; Pretzsch et al. 2013b; Pretzsch et al. 2015).

Several studies suggest that belowground niche complementarity in multi-species broadleaved forests of the Hainich-Dün region is limited (Meinen et al. 2009; Jacob et al. 2013). As a result, it appears likely that the (insignificant) greater annual and multiyear stem increments of target trees in mixture with valuable hardwoods (Metz et al. 2013, 2016 and 2019) were caused by increased photosynthetic performance or light use efficiency of the target trees. Lower light compensation points of beech (Lyr et al. 1967; Pretzsch et al. 2013a), interspecific variation in phenological activities (Michelot et al. 2012) or mechanical damage of neighboring (ash) crowns (Frech 2006) are possible mechanisms that may have contributed to higher target tree growth rates in mixture with valuable hardwoods compared to beeches in pure stands of the Exploratory Hainich-Dün. 


\subsection{Conclusions}

The results obtained in the three studies indicate that apart from other (co-) factors such as local climatic or edaphic conditions, disturbances, stand density and stand developmental phase (Forrester and Bauhus 2016; Mina et al. 2018), plant trait variation or rather the magnitude of functional niche complementarity (Loreau 2000) greatly influenced the relaxation-induced growth response of the beech target trees on different time scales (Metz et al. 2013, 2016 and 2019). In this context, Ammer (2019) points out that relaxation is "[...] strongly context dependent (Zhang et al. 2017; Mina et al. 2018)“. Thus, the most distinct effect on annual and multiyear growth performance of beech with neighborhoods exclusively consisting of Scots pine at the dry Schorfheide-Chorin area seemed to result from cumulative effects of below- and aboveground relaxation as well as temporal niche partitioning (Metz et al. 2013, 2016 and 2019). This is in line with other studies who stated that mixing of Scots pine and European beech enhances supply as well as capture and use efficiency of resources (Pretzsch et al. 2015; Pretzsch et al. 2016; González de Andrés et al. 2017).

In the Exploratories Hainich-Dün and Swabian Alb, the magnitude of relaxation-induced beech growth response in interspecific neighborhoods was weaker due to manifold reasons. In the multi-species broad-leaved forests (HAI), belowground niche partitioning and functional complementarity between beech and valuable hardwoods was considered to be insufficient (Meinen et al. 2009; Jacob et al. 2013). Consequently, crown plasticity of target trees in groups of interspecific competition (Fig. 5.2) and related positive effects on light interception and photosynthesis were less pronounced. At the high-precipitation Swabian Alb sites, belowground competitive superiority of European beech over Norway spruce (Schmid and Kazda 2001; Schmid 2002; Bolte and Villanueva 2006) had limited impact on growth response of the target trees due to seldom soil water depletion. Furthermore, improved aboveground resource availability was found to trigger canopy space occupation stronger than stem growth of European beech (Pretzsch and Schütze 2009; Bayer and Pretzsch 2017). In addition, compared to neighboring spruce, inferior longitudinal growth of the beech target trees from the Swabian Alb plots can be considered as disadvantage in (size-asymmetric) competition for light (Schwinning and Weiner 1998). 
In this thesis, the following three main objectives were addressed:

a) to measure the impact of competition intensity and neighborhood identity on stem growth patterns of beech target trees at various time scales (day to year)

b) to explain the revealed growth response of selected beech target trees as a function of their competitive neighborhood

c) to explain the revealed growth pattern by analyzing growth related ecophysiological and morphological plant traits such as stable isotope ratios or crown architecture

While it was not always possible to unravel if neighborhood identity per se or just competition intensity may have induced the observed growth responses and plant trait adaptations, the results of this study clearly indicate that the growth of European beech trees depends on the composition of their neighborhood. This suggests that the admixture of site-adapted cooccurring tree species can be considered as one of various appropriate silvicultural measures to mitigate the consequences of global warming and more frequent drought events on growth or water stress patterns of European beech. However, there is an urgent need for further interdisciplinary research on the importance of neighborhood competition for the adaption of beech forests (and other tree species) to climate change. Additional findings in the fields of ecophysiology, forest ecology and silviculture are necessary to better understand the interactions between endogenous factors that can be altered by forest management and exogenous factors such as climate variables (Linares et al. 2010; Ammer 2017). Further investigations should intend to combine approaches that focus on different spatial scales (individual trees, stands or landscapes) and consider a wide range of successional stages (Mölder and Leuschner 2014).

\subsection{Brief general remarks on adaptive forest management and mixed-species forests}

While this thesis focused on disentangling the influence of neighborhood identity on growth response and related plant traits of European beech, the following section intends to put these specific results into a more general context, taking current state of interdisciplinary research on mixed forests into account. This is considered necessary, because in case of interspecific competition, mutual instead of one-sided interference between neighboring trees occurs. Thus, in addition to beneficial effects of relaxation on European beech, several other reasons argue in favor of the establishment of diverse forests that contain a sufficient proportion of siteadapted admixed tree species. 
For example, different studies showed that mixed stands consisting of European beech and (complementary) tree species such as spruce, pine or oak can be more productive than the corresponding pure stands whereby beech functions as beneficiary or benefactor (Pretzsch and Schütze 2009; Pretzsch et al. 2010, 2013a, 2015). Even if Pretzsch et al. (2018) found that wood densities of several dominant tree species decreased during the last century, (transgressive) overyielding (Pretzsch and Schütze 2009) has the potential to increase carbon sequestration in forests (Mund et al. 2015), but can also bring direct monetary benefits to forest owners. Higher economic values arise not only from superior growing stocks. Especially in case of fast-growing conifers such as Norway spruce or Douglas fir, time to achieve maturity and consequently rotation periods are shorter than that of beech, so that sustainable timber harvesting can be conducted more frequently. Furthermore, compared to European beech, lower harvesting costs or planting expenses as well as higher stemwood utilization rates and average revenues in spite of distinct price volatility due to periodic calamities usually result in higher contribution margins of conifer species such as Norway spruce (Picea abies), Douglas fir (Pseudotsuga menziesii), Silver fir (Abies alba) or European larch (Larix decidua). In addition to further potential economic advantages based on risk reduction or altered survival probabilities, ecological stability and resistance of mixed stands against biotic and abiotic disturbances is considered to be greater due to diversification effects as well as higher individual stability (Jactel et al. 2005; Knoke et al. 2008; Paul et al. 2019). This supports the 'insurance hypothesis' (see also Loreau et al. 2001; Jactel et al. 2009) that has been examined theoretically from Yachi and Loreau (1999) by assessing the effects of species richness on ecosystem productivity.

Even if the importance of pure beech or conifer stands for gamma diversity should not be underestimated (Heinrichs et al. 2019), active silvicultural climate change adaption measures such as thinnings or admixtures of site-adapted tree species that facilitate increasing spatial and temporal variability of stages and stand structures at the landscape level may, apart from business aspects, also have positive effects on regional biodiversity if the amount of deadwood within the stands is sufficient (Schall et al. 2018). Thus, taking nature conservation goals in forests as well as economic considerations into account, small-scale enrichment plantings of conifers in pure beech stands can be regarded as a "no-regret" option (Hallegatte 2009) because no adverse impacts must be expected if predicted worst case climate change scenarios do not occur. However, as more light-demanding tree species are frequently outcompeted by European beech in later stand developmental stages due to its high interspecific competitiveness (Hobi et al. 2015), tree species regulation instead of natural successional 
processes are oftentimes necessary to preserve species diversity (Kölling et al. 2005; Ammer 2019).

From today's perspective, a final evaluation of the future cultivation suitability of European beech (and other tree species) is not possible (Sutmöller et al. 2008). Therefore, recommendations for the silvicultural management of (temperate European) beech stands given by Bolte (2005), Sutmöller et al. (2008) or Brang et al. (2014) that confirm the conclusions drawn from the findings presented in this thesis and other studies should be taken into account. In addition to a strict observation of site conditions and related biotic or abiotic cultivation risks, these authors enumerate several silvicultural measures for a risk-conscious management of beech stands:

- The establishment of mixed forests

- Graduated thinnings from above that preserve the (soil ameliorating) second storey

- Target diameter harvesting that considers dimension, quality, vitality and canopy class

- Group selection felling to create canopy gaps instead of shelterwood system felling may reduce overstorey competition and water stress for beech seedlings

- Increased numbers of crop trees, to compensate potential losses due to damage by disturbances

- Introduction of drought tolerant and adaptive beech provenances from other habitats or the edges of the natural distribution range. However, Ammer et al. (2005) judge the suitability of foreign provenances critically. They refer to higher risks of damage by winter or late spring frost and possible losses in timber quality respectively growth. Thus, the authors recommend utilizing the high genetic variation within or between local ecotypes in the course of natural regeneration for the adaptation to climate change instead. 


\subsection{References}

Ammer C, Albrecht L, Borchert H, Brosinger F, Dittmar C, Elling W, Ewald J, Felbermeier B, von Gilsa H, Huss J, Kenk G, Kolling C, Kohnle U, Meyer P, Mosandl R, Moosmayer HU, Palmer S, Reif A, Rehfuess KE, Stimm B (2005) Future suitability of beech (Fagus sylvatica L.) in Central Europe: Critical remarks concerning a paper of Rennenberg et al. (2004). Allgemeine Forst- und Jagdzeitung 176:60-67

Ammer C (2017) Unraveling the Importance of Inter- and Intraspecific Competition for the Adaptation of Forests to Climate Change. In: Cánovas FM, Lüttge U, Matyssek R (eds) Progress in Botany Vol. 78. Springer International Publishing, Cham, pp 345-367

Ammer C (2019) Diversity and forest productivity in a changing climate. New Phytologist 221:50-66.

André F, Jonard M, Ponette Q (2008) Spatial and temporal patterns of throughfall chemistry within a temperate mixed oak-beech stand. Science of the Total Environment 397:215228.

Barbaroux C, Bréda N (2002) Contrasting distribution and seasonal dynamics of carbohydrate reserves in stem wood of adult ring-porous sessile oak and diffuse-porous beech trees. Tree Physiology 22:1201-1210.

Bayer D, Pretzsch H (2017) Reactions to gap emergence: Norway spruce increases growth while European beech features horizontal space occupation - evidence by repeated 3D TLS measurements. Silva Fennica 51 no. 5, article id 7748: 20 p.

Berger TW, Swoboda S, Prohaska T, Glatzel G (2006) The role of calcium uptake from deep soils for spruce (Picea abies) and beech (Fagus sylvatica). Forest Ecology and Management 229:234-246.

Bertness MD, Callaway R (1994) Positive interactions in communities. Trends in Ecology \& Evolution 9:191-193.

Binkley D (2003) Seven decades of stand development in mixed and pure stands of conifers and nitrogen-fixing red alder. Canadian Journal of Forest Research 33:2274-2279.

Bolte A (2005) Zur Zukunft der Buche in Mitteleuropa: Die klimatische Anpassungsfähigkeit der „Mutter des Waldes“. AFZ - Der Wald 60:1077-1078 
Bolte A, Villanueva I (2006) Interspecific competition impacts on the morphology and distribution of fine roots in European beech (Fagus sylvatica L.) and Norway spruce (Picea abies (L.) Karst.). European Journal of Forest Research 125:15-26.

Brang P, Spathelf P, Larsen JB, Bauhus J, Boncčìna A, Chauvin C, Drössler L, GarcíaGüemes C, Heiri C, Kerr G, Lexer MJ, Mason B, Mohren F, Mühlethaler U, Nocentini S, Svoboda M (2014) Suitability of close-to-nature silviculture for adapting temperate European forests to climate change. Forestry 87:492-503.

Callaway RM (1995) Positive interactions among plants. The Botanical Review 61:306-349.

Curt T, Prévosto B (2003) Root biomass and rooting profile of naturally regenerated beech in mid-elevation Scots pine woodlands. Plant Ecology 167:269-282.

Dieler J, Pretzsch H (2013) Morphological plasticity of European beech (Fagus sylvatica L.) in pure and mixed-species stands. Forest Ecology and Management 295:97-108.

Ellenberg H, Leuschner C (2010) Vegetation Mitteleuropas mit den Alpen. In ökologischer, dynamischer und historischer Sicht, 6th edn. Eugen Ulmer, Stuttgart

Forrester DI (2015) Transpiration and water-use efficiency in mixed-species forests versus monocultures: effects of tree size, stand density and season. Tree Physiology 35:289-304.

Forrester DI, Bauhus J (2016) A Review of Processes Behind Diversity--Productivity Relationships in Forests. Current Forestry Reports 2:45-61.

Frech A (2006) Walddynamik in Mischwäldern des Nationalparks Hainich. Untersuchung der Mechanismen und Prognose der Waldentwicklung. Berichte des Forschungszentrums Waldökosysteme der Universität Göttingen, Reihe A, Band 196. Forschungszentrum Waldökosysteme der Universität Göttingen, Göttingen

Gebauer T, Horna V, Leuschner C (2012) Canopy transpiration of pure and mixed forests with variable abundance of European beech. Journal of Hydrology 442-443:2-14

Gebhardt T, Häberle K-H, Matyssek R, Schulz C, Ammer C (2014) The more, the better? Water relations of Norway spruce stands after progressive thinning. Agricultural and Forest Meteorology 197: 235-243.

González de Andrés E, Seely B, Blanco JA, Imbert JB, Lo Y-H, Castillo FJ (2017) Increased complementarity in water-limited environments in Scots pine and European beech mixtures under climate change. Ecohydrology 10:e1810. 
Grossman JJ, Cavender-Bares J, Hobbie SE, Reich PB, Montgomery RA (2017) Species richness and traits predict overyielding in stem growth in an early-successional tree diversity experiment. Ecology 98:2601-2614.

Hafner BD, Tomasella M, Häberle K-H, Goebel M, Matyssek R, Grams TEE (2017)

Hydraulic redistribution under moderate drought among English oak, European beech and Norway spruce determined by deuterium isotope labeling in a split-root experiment. Tree Physiology 37:950-960.

Hallegatte S (2009) Strategies to adapt to an uncertain climate change. Global Environmental Change 19:240-247.

Handa IT, Aerts R, Berendse F, Berg MP, Bruder A, Butenschoen O, Chauvet E, Gessner MO, Jabiol J, Makkonen M, McKie BG, Malmqvist B, Peeters ETHM, Scheu S, Schmid B, van Ruijven J, Vos VCA, Hättenschwiler S (2014) Consequences of biodiversity loss for litter decomposition across biomes. Nature 509:218-221.

Hartmann H (2011) Will a 385 million year-struggle for light become a struggle for water and for carbon? - How trees may cope with more frequent climate change-type drought events. Global Change Biology 17:642-655.

Heinrichs S, Ammer C, Mund M, Boch S, Budde S, Fischer M, Müller J, Schöning I, Schulze E-D, Schmidt W, Weckesser M, Schall P (2019) Landscape-Scale Mixtures of Tree Species are More Effective than Stand-Scale Mixtures for Biodiversity of Vascular Plants, Bryophytes and Lichens. Forests 10:73.

Hobi ML, Commarmot B, Bugmann H (2015) Pattern and process in the largest primeval beech forest of Europe (Ukrainian Carpathians). Journal of Vegetation Science 26:323336.

Ilek A, Kucza J, Szostek M (2015) The effect of stand species composition on water storage capacity of the organic layers of forest soils. European Journal of Forest Research 134:187-197. doi: 10.1007/s10342-014-0842-2

Jacob M, Viedenz K, Polle A, Thomas FM (2010b) Leaf litter decomposition in temperate deciduous forest stands with a decreasing fraction of beech (Fagus sylvatica). Oecologia 164:1083-1094. 
Jacob M, Weland N, Platner C, Schaefer M, Leuschner C, Thomas FM (2009) Nutrient release from decomposing leaf litter of temperate deciduous forest trees along a gradient of increasing tree species diversity. Soil Biology and Biochemistry 41:2122-2130.

Jacob A, Hertel D, Leuschner C (2013) On the significance of belowground overyielding in temperate mixed forests: separating species identity and species diversity effects. Oikos $122: 463-473$.

Jactel H, Brockerhoff E, Duelli P (2005) A Test of the Biodiversity-Stability Theory: Metaanalysis of Tree Species Diversity Effects on Insect Pest Infestations, and Re-examination of Responsible Factors. In: Scherer-Lorenzen M, Körner C, Schulze E-D (eds) Forest Diversity and Function: Temperate and Boreal Systems. Ecological Studies (Analysis and Synthesis) vol 176. Springer, Berlin, Heidelberg, pp 235-262

Jactel H, Nicoll BC, Branco M, González-Olabarria JR, Grodzki W, Långström B, Moreira F, Netherer S, Orazio C, Piou D, Santos H, Schelhaas MJ, Tojic K, Vodde F (2009) The influences of forest stand management on biotic and abiotic risks of damage. Annals of Forest Science 66:701.

Jucker T, Bouriaud O, Coomes DA (2015) Crown plasticity enables trees to optimize canopy packing in mixed-species forests. Functional Ecology 29:1078-1086.

Knoke T, Ammer C, Stimm B, Mosandl R (2008) Admixing broadleaved to coniferous tree species: a review on yield, ecological stability and economics. European Journal of Forest Research 127:89-101.

Köcher P, Gebauer T, Horna V, Leuschner C (2009) Leaf water status and stem xylem flux in relation to soil drought in five temperate broad-leaved tree species with contrasting water use strategies. Annals of Forest Science 66:101.

Kölling C, Walentowski H, Borchert H (2005) Die Buche in Mitteleuropa: Eine Waldbaumart mit grandioser Vergangenheit und sicherer Zukunft. AFZ - Der Wald 60:696-701

Kunert N, Schwendenmann L, Potvin C, Hölscher D (2012) Tree diversity enhances tree transpiration in a Panamanian forest plantation. Journal of Applied Ecology 49:135-144.

Lang C (2008) Diversität der Ektomykorrhizen in verschieden artenreichen Laubbaumbeständen im Nationalpark Hainich (Thüringen). Dissertation Universität Göttingen 2008. Göttinger Forstwissenschaften, vol 1. Universitätsverlag Göttingen, Göttingen 
Lang C, Polle A (2011) Ectomycorrhizal fungal diversity, tree diversity and root nutrient relations in a mixed Central European forest. Tree Physiology 31:531-538.

Linares JC, Camarero JJ, Carreira JA (2010) Competition modulates the adaptation capacity of forests to climatic stress: insights from recent growth decline and death in relict stands of the Mediterranean fir Abies pinsapo. Journal of Ecology 98:592-603.

Loreau M (2000) Biodiversity and ecosystem functioning: recent theoretical advances. Oikos 91:3-17.

Loreau M, Naeem S, Inchausti P, Bengtsson J, Grime JP, Hector A, Hooper DU, Huston MA, Raffaelli D, Schmid B, Tilman D, Wardle DA (2001) Biodiversity and Ecosystem Functioning: Current Knowledge and Future Challenges. Science 294:804-808.

Lyr H, Polster H, Fiedler H-J (1967) Gehölzphysiologie. VEB Gustav-Fischer-Verlag, Jena

Meinen C, Leuschner C, Ryan N, Hertel D (2009) No evidence of spatial root system segregation and elevated fine root biomass in multi-species temperate broad-leaved forests. Trees - Structure and Function 23:941-950.

Metz J, Annighöfer P, Westekemper K, Schall P, Schulze E-D, Ammer C (2019) Less is more: Effects of competition reduction and facilitation on intra-annual (basal area) growth of mature European beech. Trees, DOI:10.1007/s00468-019-01894-7.

Metz J, Seidel D, Schall P, Scheffer D, Schulze E-D, Ammer C (2013) Crown modeling by terrestrial laser scanning as an approach to assess the effect of aboveground intra- and interspecific competition on tree growth. Forest Ecology and Management 310:275-288.

Metz J, Annighöfer P, Schall P, Zimmermann J, Kahl T, Schulze E-D, Ammer C (2016) Siteadapted admixed tree species reduce drought susceptibility of mature European beech. Global Change Biology 22:903-920.

Michelot A, Simard S, Rathgeber C, Dufrêne E, Damesin C (2012) Comparing the intraannual wood formation of three European species (Fagus sylvatica, Quercus petraea and Pinus sylvestris) as related to leaf phenology and non-structural carbohydrate dynamics. Tree Physiology 32:1033-1045.

Mina M, Huber MO, Forrester DI, Thürig E, Rohner B (2018) Multiple factors modulate tree growth complementarity in Central European mixed forests. Journal of Ecology 106:1106-1119. 
Mölder I, Leuschner C (2014) European beech grows better and is less drought sensitive in mixed than in pure stands: tree neighbourhood effects on radial increment. Trees Structure and Function 28:777-792.

Mölder I, Leuschner C, Leuschner HH (2011) $\delta^{13} \mathrm{C}$ signature of tree rings and radial increment of Fagus sylvatica trees as dependent on tree neighborhood and climate. Trees - Structure and Function 25:215-229.

Mund M, Frischbier N, Profft I, Raacke J, Richter F, Ammer C (2015) Klimaschutzwirkung des Wald- und Holzsektors: Schutz- und Nutzungsszenarien für drei Modellregionen in Thüringen: Ergebnisse des F+E-Vorhabens „Ökosystemleistungen naturnaher Wälder in der Wald- und Klimapolitik“. BfN-Skripten, vol 396, Bonn

Oberhuber W, Gruber A, Kofler W, Swidrak I (2014) Radial stem growth in response to microclimate and soil moisture in a drought-prone mixed coniferous forest at an inner Alpine site. European Journal of Forest Research 133:467-479.

Paul C, Brandl S, Friedrich S, Falk W, Härtl F, Knoke T (2019) Climate change and mixed forests: how do altered survival probabilities impact economically desirable species proportions of Norway spruce and European beech? Annals of Forest Science. 76:14.

Poorter H, Niklas KJ, Reich PB, Oleksyn J, Poot P, Mommer L (2012) Biomass allocation to leaves, stems and roots: meta-analyses of interspecific variation and environmental control. New Phytologist 193:30-50.

Pretzsch H, Schütze G (2005) Crown allometry and growing space efficiency of Norway spruce (Picea abies L. Karst.) and European beech (Fagus sylvatica L.) in pure and mixed stands. Plant Biology 7:628-639.

Pretzsch H, Schütze G (2009) Transgressive overyielding in mixed compared with pure stands of Norway spruce and European beech in Central Europe: evidence on stand level and explanation on individual tree level. European Journal of Forest Research 128:183-204.

Pretzsch H, Block J, Dieler J, Dong PH, Kohnle U, Nagel J, Spellmann H, Zingg A (2010) Comparison between the productivity of pure and mixed stands of Norway spruce and European beech along an ecological gradient. Annals of Forest Science 67:712.

Pretzsch H, Bielak K, Block J, Bruchwald A, Dieler J, Ehrhart H-P, Kohnle U, Nagel J, Spellmann H, Zasada M, Zingg A (2013a) Productivity of mixed versus pure stands of oak (Quercus petraea (Matt.) Liebl. and Quercus robur L.) and European beech (Fagus 
sylvatica L.) along an ecological gradient. European Journal of Forest Research 132:263-280.

Pretzsch H (2014) Canopy space filling and tree crown morphology in mixed-species stands compared with monocultures. Forest Ecology and Management 327:251-264.

Pretzsch H, Schütze G, Uhl E (2013b) Resistance of European tree species to drought stress in mixed versus pure forests: evidence of stress release by inter-specific facilitation. Plant Biology 15:483-495.

Pretzsch H, del Río M, Ammer C, Avdagic A, Barbeito I, Bielak K, Brazaitis G, Coll L, Dirnberger G, Drössler L, Fabrika M, Forrester DI, Godvod K, Heym M, Hurt V, Kurylyak V, Löf M, Lombardi F, Matović B, Mohren F, Motta R, den Ouden J, Pach M, Ponette Q, Schütze G, Schweig J, Skrzyszewski J, Sramek V, Sterba H, Stojanović D, Svoboda M, Vanhellemont M, Verheyen K, Wellhausen K, Zlatanov T, Bravo-Oviedo A (2015) Growth and yield of mixed versus pure stands of Scots pine (Pinus sylvestris L.) and European beech (Fagus sylvatica L.) analysed along a productivity gradient through Europe. European Journal of Forest Research 134:927-947.

Pretzsch H, del Río M, Schütze G, Ammer C, Annighöfer P, Avdagic A, Barbeito I, Bielak K, Brazaitis G, Coll L, Drössler L, Fabrika M, Forrester DI, Kurylyak V, Löf M, Lombardi F, Matović B, Mohren F, Motta R, den Ouden J, Pach M, Ponette Q, Skrzyszewski J, Sramek V, Sterba H, Svoboda M, Verheyen K, Zlatanov T, Bravo-Oviedo A (2016) Mixing of Scots pine (Pinus sylvestris L.) and European beech (Fagus sylvatica L.) enhances structural heterogeneity, and the effect increases with water availability. Forest Ecology and Management 373:149-166.

Pretzsch H, Biber P, Schütze G, Kemmerer J, Uhl E (2018) Wood density reduced while wood volume growth accelerated in Central European forests since 1870. Forest Ecology and Management 429:589-616.

Primicia I, Camarero JJ, Imbert JB, Castillo FJ (2013) Effects of thinning and canopy type on growth dynamics of Pinus sylvestris: inter-annual variations and intra-annual interactions with microclimate. European Journal of Forest Research 132:121-135.

Schall P, Gossner MM, Heinrichs S, Fischer M, Boch S, Prati D, Jung K, Baumgartner V, Blaser S, Böhm S, Buscot F, Daniel R, Goldmann K, Kaiser K, Kahl T, Lange M, Müller J, Overmann J, Renner SC, Schulze E-D, Sikorski J, Tschapka M, Türke M, Weisser WW, Wemheuer B, Wubet T, Ammer C (2018) The impact of even-aged and uneven- 
aged forest management on regional biodiversity of multiple taxa in European beech forests. Journal of Applied Ecology 55:267-278.

Schmid I, Kazda M (2001) Vertical distribution and radial growth of coarse roots in pure and mixed stands of Fagus sylvatica and Picea abies. Canadian Journal of Forest Research 31:539-548.

Schmid I, Kazda M (2002) Root distribution of Norway spruce in monospecific and mixed stands on different soils. Forest Ecology and Management 159:37-47.

Schmid I (2002) The influence of soil type and interspecific competition on the fine root system of Norway spruce and European beech. Basic and Applied Ecology 3:339-346.

Schmidt M, Veldkamp E, Corre MD (2015) Tree species diversity effects on productivity, soil nutrient availability and nutrient response efficiency in a temperate deciduous forest. Forest Ecology and Management 338:114-123.

Schume H, Jost G, Hager H (2004) Soil water depletion and recharge patterns in mixed and pure forest stands of European beech and Norway spruce. Journal of Hydrology 289:258274.

Schwendenmann L, Pendall E, Sanchez-Bragado R, Kunert N, Hölscher D (2015) Tree water uptake in a tropical plantation varying in tree diversity: interspecific differences, seasonal shifts and complementarity. Ecohydrology 8:1-12.

Schwinning S, Weiner J (1998) Mechanisms determining the degree of size asymmetry in competition among plants. Oecologia 113:447-455.

Shipley B, Meziane D (2002) The balanced-growth hypothesis and the allometry of leaf and root biomass allocation. Functional Ecology 16:326-331.

Skomarkova MV, Vaganov EA, Mund M, Knohl A, Linke P, Boerner A, Schulze E-D (2006) Inter-annual and seasonal variability of radial growth, wood density and carbon isotope ratios in tree rings of beech (Fagus sylvatica) growing in Germany and Italy. Trees Structure and Function 20:571-586.

Sutmöller J, Spellmann H, Fiebiger C, Albert M (2008) Der Klimawandel und seine Auswirkungen auf die Buchenwälder in Deutschland: The effects of climate change on beech forests in Germany. In: NW-FVA (ed) Ergebnisse angewandter Forschung zur Buche: Beiträge aus der Nordwestdeutschen Forstlichen Versuchsanstalt Band 3. Universitätsverlag Göttingen, Göttingen, pp 135-158 
Suzuki M, Yoda K, Suzuki H (1996) Phenological comparison of the onset of vessel formation between ring-porous and diffuse-porous deciduous trees in a Japanese temperate forest. IAWA journal 17:431-444

Wipfler P, Seifert T, Biber P, Pretzsch H (2009) Intra-annual growth response of adult Norway spruce (Picea abies [L.] KARST.) and European beech (Fagus sylvatica L.) to an experimentally enhanced, free-air ozone regime. European Journal of Forest Research 128:135-144.

Yachi S, Loreau M (1999) Biodiversity and ecosystem productivity in a fluctuating environment: the insurance hypothesis. Proceedings of the National Academy of Sciences of the United States of America 96:1463-1468.

Zapater M, Hossann C, Bréda N, Bréchet C, Bonal D, Granier A (2011) Evidence of hydraulic lift in a young beech and oak mixed forest using ${ }^{18} \mathrm{O}$ soil water labelling. Trees - Structure and Function 25:885-894.

Zhang Y, Chen HYH, Taylor AR (2017) Positive species diversity and above-ground biomass relationships are ubiquitous across forest strata despite interference from overstorey trees. Functional Ecology 31:419-426. 


\section{Publication list of author}

\section{Journal articles}

Metz J, Annighöfer P, Westekemper K, Schall P, Schulze ED, Ammer C (2019) Less is more: Effects of competition reduction and facilitation on intra-annual (basal area) growth of mature European beech. Trees, DOI:10.1007/s00468-019-01894-7

Annighöfer P, Metz J, Schall P, Schulze ED, Ammer C (2017) Buche in Mischbeständen bei Trockenheit weniger gestresst. AFZ - Der Wald 72 (17): 13-15

Metz J, Annighöfer P, Schall P, Zimmermann J, Kahl T, Schulze ED, Ammer C (2016) Siteadapted admixed tree species reduce drought susceptibility of mature European beech. Global Change Biology 22: 903-920

Metz J, Seidel D, Schall P, Scheffer D, Schulze ED, Ammer C (2013) Crown modeling by terrestrial laser scanning as an approach to assess the effect of aboveground intra-and interspecific competition on tree growth. Forest Ecology and Management 310: 275-288

Metz J, Brokmeier H, (2011) Einfluss des Reifenfülldruckes auf Waldwegeschäden. AFZ Der Wald 10: 42-45

\section{Conference contributions}

Detecting tree competition - from model to measurement (Poster presentation at SilviLaser Conference, 16-19 September 2012, Vancouver, Canada)

Konkurrenz belebt das Geschäft! Gilt das auch für die Buche? (Talk at the $4^{\text {th }}$ Science Day of the Biosphere Reserve Schorfheide-Chorin, Eberswalde, Germany, 14 November 2012) 


\section{Acknowledgements}

I would like to give my particular thanks to a number of people and institutions, without their knowledge, trust and encouragement this (mammoth) project would not have been possible.

First of all, I wish to express my deepest gratitude towards Prof. Dr. Christian Ammer for the impressive support, unshakeable patience and belief in me throughout the last years. He promoted my interest in silvicultural research from the very beginning, provided the best possible working environment and guided me on the long road towards completion of this thesis.

Special thanks belong to Prof. Dr. Ernst-Detlef Schulze for his interest in my studies, his valuable contributions during all phases of the work on the project 'Neighbor', for sharing his amazing knowledge on forest ecosystems with me and for his willingness to become a member of my supervisors committee.

Prof. Dr. Alexander Knohl deserves thanks for becoming a member of the examination board. I say wholeheartedly 'Thank you' to Dr. Peter Annighöfer, Dr. Peter Schall and Dr. Dominik Seidel. They discussed innumerable questions with me, were the best possible counselors and supported me in solving (insolvable) statistical or software problems. Without our common coffee breaks, I would probably have given up more than once.

I also want to thank Ulrike Westphal, Karl-Heinz Heine, Michael Unger and Andreas Parth for helping me with extensive field and laboratory work as well as for their technical support with measuring devices of all kind.

I thank Dr. Johannes Gerst for our joint doctoral student days and for becoming such a good friend.

I am grateful to Silke Marks and all other colleagues, doctoral candidates and student helpers, who attended and motivated me during my great time at the Department of Silviculture and Forest Ecology of the Temperate Zones.

I say 'Thank you' to the Deutsche Forschungsgesellschaft (DFG) for funding this research project what enabled me to enhance my professional and personal skills.

I appreciate the outstanding cooperation with the staff of the Biodiversity Exploratories local management teams, who were very helpful in maintenance of instrumentation infrastructure and providing field work permits. 
My sincere thanks go to Dr. Silke Schweighoefer, Ulrich Pruschitzki and the colleagues from the Department of Plant Ecology and Ecosystems Research for introducing me into the technology of dendrometer measurements and tree ring analyses.

I am indebted to my superiors at 'HessenForst' for encouraging me to accomplish this dissertation.

I owe my loving thanks to my parents and my brother, who always gave me the courage and strength to go my own way. Your unlimited family support means everything to me.

I am privileged to have the most wonderful wife and son on earth. Karoline and Maximilian, this work would have never been finished without your endless patience, loving support and considerateness. Sharing my life with you two makes me incredibly happy, proud and thankful!

Last but not least, I owe a great dept of gratitude to "my" trees on the study sites for providing so much information willingly and for revealing some (small) secrets to me. 


\section{Curriculum vitae}

\section{Personal information}

Name: Jérôme Metz

Date of Birth: 2 February 1985

Place of birth: Lebach

Nationality: German

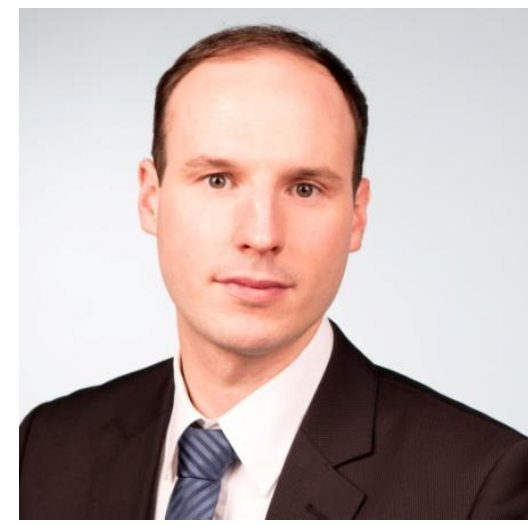

\section{Work Experience}

09/2017 - present Division Manager Production \& Deputy Head of the HessenForst Forestry District Frankenberg

08/2016 - 08/2017 Operations Assistant (Higher Service) to the Chief Operating Officer of the "Landesbetriebsleitung HessenForst"

06/2014 - 05/2016 "Forstreferendariat" (Compulsory Traineeship for the Occupational Career in the Higher Forestry-Technical Service in the Federal State of Hesse) with the Final State Examination in Forestry

04/2011 - 08/2019 Scientific Assistant / Doctoral Researcher

Georg-August-University, Göttingen

Faculty of Forest Sciences and Forest Ecology

Department of Silviculture and Forest Ecology of the Temperate Zones

\section{Academic Studies}

$\begin{array}{cl}\text { 04/2011 - 08/2019 } & \begin{array}{l}\text { PhD program Forest Sciences and Forest Ecology } \\ \text { Georg-August-University, Göttingen }\end{array} \\ 10 / 2008-12 / 2010 & \begin{array}{l}\text { Master program Forest Sciences and Forest Ecology } \\ \text { Georg-August-University, Göttingen } \\ \text { Major Field of Study: Forest Management and Forest Utilisation }\end{array} \\ \text { 10/2005-09/2008 } & \begin{array}{l}\text { Bachelor program Forest Sciences and Forest Ecology } \\ \text { Georg-August-University, Göttingen }\end{array}\end{array}$

Basic Military Service

04/2004 - 12/2004 $\quad 1^{\text {st }}$ Rocket Artillery Training Bataillon 52, Hermeskeil

\section{School Education}

08/1995 - 03/2004 Comprehensive Secondary School "Max-Planck-Gymnasium", Trier General Qualification for University Entrance

$1991-1995 \quad$ Basic Primary School, Trier-Irsch 


\section{Declaration of originality and certificate of ownership}

I, Jérôme Metz, hereby declare that I am the sole author of this dissertation entitled 'THE EFFECT OF NEIGHBORHOOD IDENTITY ON SEASONAL TREE GROWTH RESPONSES AND ECOPHYSIOLOGICAL CHARACTERISTICS OF EUROPEAN BEECH (FAGUS SYLVATICA L.)'. All references and data sources that were used in the dissertation have been acknowledged as such. I further declare that this work has never been submitted in any form as part of another dissertation procedure. 